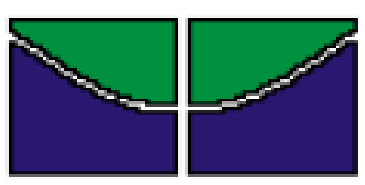

Universidade de Brasília

Departamento de Biologia Celular

Programa de Pós-Graduação em Biologia Molecular

\title{
Filogeografia, Epidemiologia Viral e Capacidade Evolutiva via Rearranjo Genético de Tospovirus
}

Mariana Martins Severo de Almeida

Brasília, 2016 


\section{Filogeografia, Epidemiologia Viral e Capacidade Evolutiva via Rearranjo Genético de Tospovirus}

Tese submetida à Coordenação do curso de Pós-Graduação de Biologia Molecular da Universidade de Brasília como requisito parcial para obtenção do título de Doutor.

Orientador: Dr. Renato de Oliveira Resende

Brasília, 2016 
Aos meus pais Francisco Alberto e Santusa, aos meus irmãos Ana Carolina e Felipe, dedico esta tese pelo amor, pelo carinho, por sempre acreditarem nas minhas escolhas e incentivarem meu trabalho. 


\section{Agradecimentos}

À minha família, meu pai Francisco Alberto, minha mãe Santusa, meu irmão Felipe, minha irmã Ana Carolina, meu cunhado André e meu sobrinho Matheus pelo apoio, incentivo, confiança, pelos renovadores momentos em família e, principalmente, pelas constantes demonstrações de amor e respeito.

Ao meu orientador, Dr. Renato de Oliveira Resende, pelos ensinamentos e paciência, pela convivência, orientação, pelo incentivo, confiança, apoio e respeito.

Às minhas queridas amigas de infância Priscila, Carolina, Larissa, Iruska, Maíra e Ticiane pelos muitos anos de amizade, união e de boas risadas, confortando os momentos difíceis.

Aos meus amigos do Laboratório de Virologia da Universidade de Brasília: Rayane, Athos, Karina, Anelise, Daniel, Anna Fernanda, Lorena, Leonardo, Suzanne, Gabriela, Jamile, Estela por toda ajuda, companheirismo no dia-a-dia e por tornar o ambiente de trabalho mais alegre e prazeroso.

Ao colega Fernando Lucas Melo pelos muitos ensinamentos e pela constante disponibilidade em ajudar.

Ao Dr. Richard Kormelink e aos colegas de trabalho do grupo de Virologia da Universidade de Wargeningen, Países Baixos, pelo acolhimento, apoio, pelos ensinamentos e pelas parcerias realizadas.

Aos professores e funcionários do curso de Pós-Graduação em Biologia Molecular da Universidade de Brasília pelos ensinamentos científicos.

Aos membros da banca examinadora pela atenção dispensada. 
Ao CNPq pelo auxílio financeiro concedido.

À Universidade de Brasília por oferecer a infraestrutura necessária para execução dos trabalhos.

Agradeço muito à todas essas pessoas e instituições que fizeram do meu trabalho um prazer e não uma obrigação. 
Banca Examinadora:

Renato de Oliveira Resende (Orientador)

Universidade de Brasília (UnB)

Tatsuya Nagata

Universidade de Brasília (UnB)

Leonardo Silva Boiteux

Embrapa Hortaliças (CNPH) 
Banca Examinadora:

Rosana Blawid

Universidade de Brasília (UnB)

\section{Marília Santos Silva}

Embrapa Recursos Genéticos e Biotecnologia (CNPH) 


\section{Resumo}

Os vírus do gênero Tospovirus pertencem à família Bunyaviridae e possuem o material genético composto por três segmentos de RNA, denominados RNA L, RNA M e RNA S. O Groundnut ringspot virus (GRSV) e o Tomato spotted wilt virus (TSWV) são as espécies de tospovírus mais importantes no Brasil, causando prejuízos principalmente em cultivos de tomateiro e pimenteiras. Tomato chlorotic spot virus (TCSV) eventualmente é encontrado em ciclo de hospedeiras similar ao de GRSV e TSWV e tem ocorrência restrita a alguns estados no Brasil, onde foi descrito pela primeira vez. Vírus compostos por genoma segmentado podem sofrer frequentes recombinações ou rearranjos. Com a finalidade de buscar rearranjos naturais entre espécies de tospovírus, foi verificada a ocorrência de GRSV, TCSV e TSWV em amostras com sintomas de vírus coletadas no Brasil e na República Dominicana. Neste levantamento não foram detectados rearranjos genéticos e a incidência de infecção mista foi de apenas 7\%. Contudo, mais de 50\% das amostras coletadas estavam infectadas com tospovírus, reforçando a importância econômica desses vírus. No Brasil houve a prevalência de GRSV, mantendo o cenário observado no último estudo de detecção de tospovírus em amostras de campo, no qual também se verificou a prevalência de GRSV em regiões produtoras no Nordeste e no Distrito federal. Comparando-se os dados do levantamento anterior com aquele realizado nesse estudo, pode-se perceber que TSWV está perdendo espaço no campo, deixando de ser a espécie de maior relevância econômica. Na República Dominicana, região onde os tospovírus foram introduzidos recentemente, observou-se que o TCSV tem se disseminado de forma rápida e severa em importantes culturas como tomateiro, pimenteiras, fumo e feijoeiro, em contraste com o GRSV que ainda não foi detectado no país e o TSWV que foi encontrado em uma proporção maior do que a observada no Brasil. A crescente disseminação de TCSV não está restrita à República Dominicana e pode ser justificada pelo 'fitness' mais eficiente desta espécie. Relatos recentes têm ocorrido em outros países do Caribe e nos Estados Unidos, onde foi caracterizado o primeiro isolado proveniente de rearranjo intraespecífico de tospovírus composto por segmentos genômicos não cognatos. Este isolado heterogêneo possui os RNAs S e L de GRSV e o RNA M de TCSV ( $S_{\text {GRSVM MCSVL }} L_{G R S V}$ ). Pela diversidade biológica e devido aos critérios taxonômicos estabelecidos, foi pressuposto que a detecção de rearranjos nas condições 
brasileiras havia sido negligenciada ao longo dos anos. Contudo, após a análise de mais de cento e sessenta amostras, coletadas em dois países com históricos de infecções de tospovirus bem distintos (Brasil e República Dominicana), não foi possível detectar rearranjos genéticos. Neste trabalho foram sequenciados e comparados isolados de TCSV e de GRSV coletados no final dos anos 80, com isolados sequenciados recentemente e/ou armazenados em bancos de dados genômicos. As análises de filogenia do RNA M de TCSV e GRSV permitiram concluir que, provavelmente, essas duas espécies compartilham o mesmo segmento M, ou seja, caso tenha ocorrido algum evento definitivo de rearranjo entre as espécies de GRSV e TCSV, este foi em um passado distante, não sendo possível detectar o segmento parental por falta de dados suficientes para as análises. Neste trabalho, a distribuição mundial de TCSV, TSWV e de Iris yellow spot virus (IYSV) também foi verificada por meio de estudos de filogeografia, com a finalidade de compreender a dispersão de espécies de tospovirus e possibilitar a agregação de dados para implementação de medidas quarentenárias e o aperfeiçoamento de programas de melhoramento, para a obtenção de resistência genética a espécies de tospovírus. Nestas análises foi possível verificar que a distribuição dos isolados é local e não global e que a disseminação mundial dos tospovírus parece estar relacionada com as atividades econômicas e intercâmbios comerciais realizadas pelos países. 


\section{Abstract}

The viruses on the genus Tospovirus belong to the family Bunyaviridae and have their genome comprised by trisegmented RNA, named L RNA, M RNA and S RNAS. The Groundnut ringspot virus (GRSV) and Tomato spotted wilt virus (TSWV) are the most important tospovirus in Brazil, causing severe losses mainly in tomato and pepper crops. Tomato chlorotic spot virus (TCSV) is often found infecting similar hosts range as GRSV and TSWV. TCSV occurrence is restricted to some states in Brazil, where it was described for the first time. Viruses having segmented genomes can undertake frequent recombinations and/or reassortants. With the aim to seek for natural reassortants among GRSV, TCSV and TSWV an extensive survey was carried out in Brazil and Dominican Republic. In this survey, any genetic reassortant was detected and the incidence of mixed infection was significantly low. However, more than $50 \%$ of the samples collected were infected with tospoviruses, reinforcing the economic importance of these viruses. In Brazil there was a prevalence of GRSV, the same scenario observed in the last tospoviruses survey in the field, which has also verified the prevalence of the GRSV in horticultural producing areas located in the Northeast and in the Federal District. As we bring together the old and the new database, we can notice that the importance of TSWV is decreasing in agriculture, since this specie is not the most economically relevance. In Dominican Republic, the TCSV has been recently reported and have been spreading over important cultivated crops, such as tomato crops, pepper crops, tobacco and bean crops. The survey in Dominican Republic showed that GRSV was not detected yet in the country and TSWV has been found in higher percentages compared to those found in Brazil. The remarkably dissemination of the TCSV is not restricted to the Dominican Republic and may be due to an efficient fitness of this species. Recent reports showed occurrence of TCSV in others Caribbean countries and in the south of USA, where it was reported the first interspecific reassortant isolate among tospoviruses. This reassortant isolate has the S and L RNA genomic segments of the GRSV and the M RNA of the TCSV (denoted as $\mathrm{S}_{\mathrm{GRSV}} \mathrm{M}_{\mathrm{TCSV}} \mathrm{L}_{\mathrm{GRSV}}$ ). Up to now, due to the biologic diversity, associate with the taxonomic criteria established, we assumed that the reassortant detection in the Brazilian conditions was neglected. However, after the analysis of more than one hundred and sixty samples, collected in two countries (Brazil and Dominican Republic), which have different tospoviruses history, genetic rearrangements were not detected. To understand the nature of the 
natural reassortant $\mathrm{S}_{\mathrm{GRSV}} \mathrm{M}_{\mathrm{TCSV}} \mathrm{L}_{\mathrm{GRSV}}$ between GRSV and TCSV, recently reported in USA, in this work, we sequenced and compared the first GRSV and TCSV isolates reported in the world, which were isolated in the 1980's, with all GRSV and TCSV available in GenBank and/or sequenced in our Lab. After a stringent analysis of the M RNA of the TCSV and GRSV phylogeny, we were able to conclude that, probably, these two species share the same M segment. In this case, we hyptothesize that the reassortant event between GRSV and TCSV occurred in a distant past (at least 30 years ago), and not recently, as reported in USA. However, it is not possible to detect the parental segment due to the lack of sequence information in the database. The world distribution of TCSV, TSWV and Iris yellow spot virus (IYSV) were also studied in this work verified by phylogeography analysis. The results aimed to gather information in order to improve the effiency of breeding programs searching for resistant or tolerant genotypes to tospovirus infection and to implement quarantine procedures. In this analysis, we could verify that the distribution of the isolates seems to be local and not global and the world dissemination of the topoviruses was related to economic activities among the countries. 


\section{Sumário}

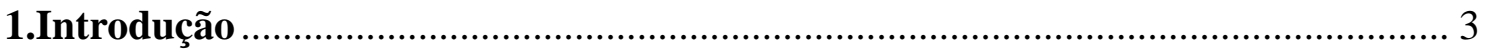

1.1 Histórico global das tospoviroses: da doença ao agente etiológico.............. 3

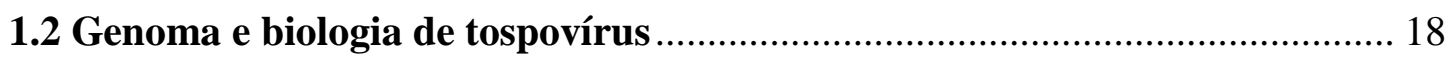

1.3 Taxonomia, filogenia e diversidade de Tospovirus ....................................... 23

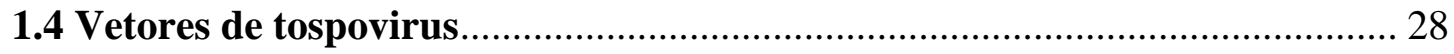

1.5 Aspectos econômicos e epidemiológicos ......................................................... 31

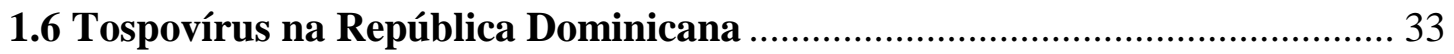

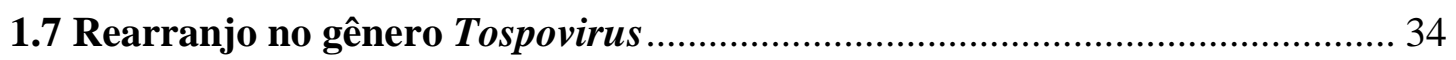

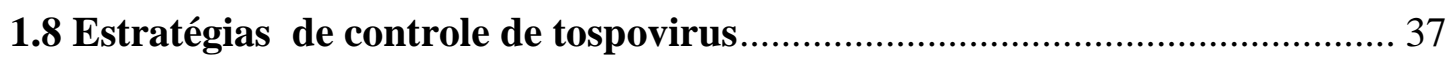

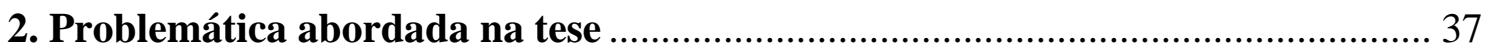

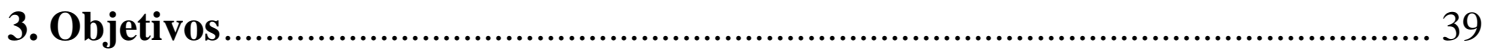

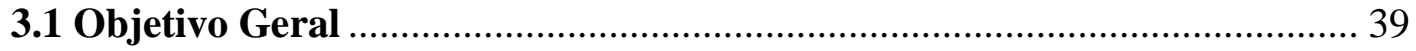

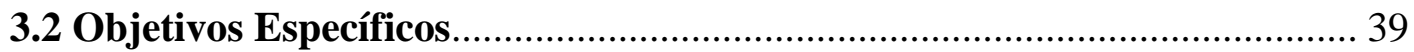

CAPÍTULO 1: Ocorrência e dispersão de Groundnut ringspot virus (GRSV), Tomato chlorotic spot virus (TCSV) e Tomato spotted wilt virus (TSWV) submetidos a diferentes condições ambientais e pressão de seleção no Brasil e na República

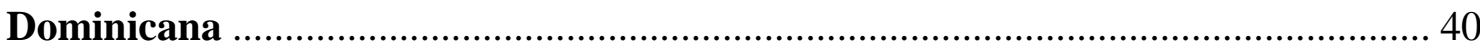

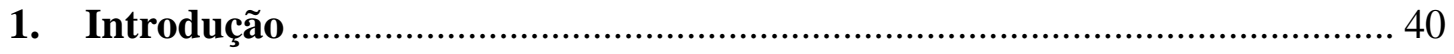

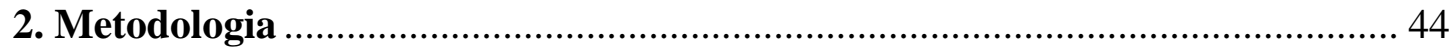

2.1 Desenvolvimento de marcadores moleculares para detecção simultânea e espécie-específica das espécies Groundnut ringspot virus (GRSV), Tomato chlorotic spot virus (TCSV) e Tomato spotted wilt virus (TSWV) ...

2.2 Metagenômica na identificação de genomas virais em plantas cultivadas na República Dominicana ........................................................................... 50

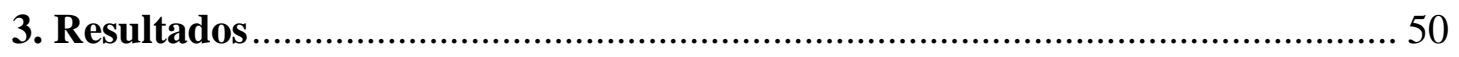

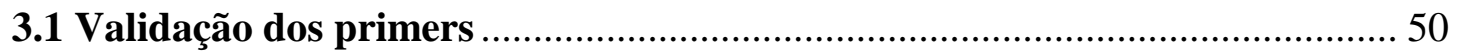

3.2 Detecção de Tospovirus nas amostras de campo......................................... 56

3.3 Detecção de viromas em plantas hortículas na República Dominicana ..... 59

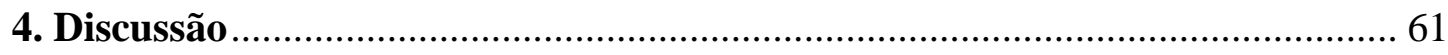

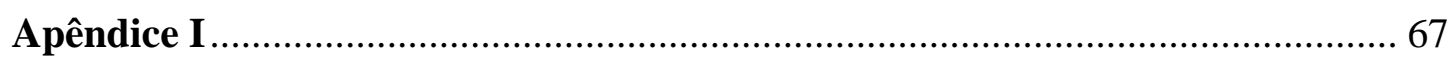

CAPÍTULO 2: Filogeografia Iris yellow spot virus (IYSV), Tomato chlorotic spot virus (TCSV) e Tomato spotted wilt virus (TSWV).

1. Introdução 


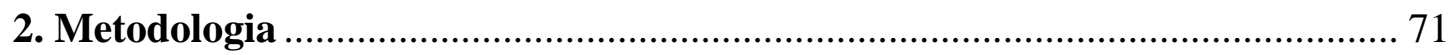

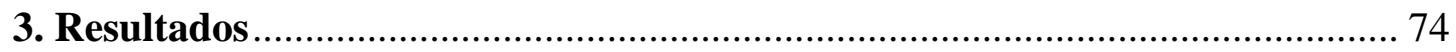

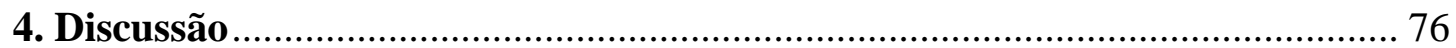

CAPÍTULO 3: Determinação do 'fitness' entre Groundnut ringspot virus (GRSV) e Tomato chlorotic spot virus (TCSV) e estudo da ancestralidade dos RNAs M de

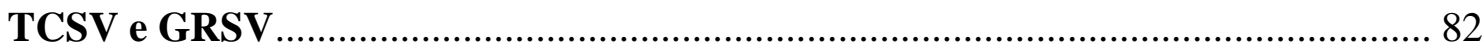

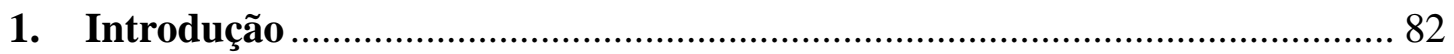

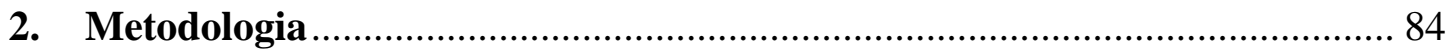

2.1. Ensaio biológico: infecção mista e análise de 'fitness' de Groundnut ringspot virus (GRSV) e Tomato chlorotic spot virus (TCSV) ............................ 84

2.3. Estudo de ancestralidade dos RNAs M de TCSV e GRSV ....................... 91

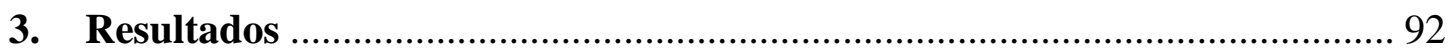

3.1. Análise da capacidade replicativa de Tomato chlorotic spot virus (TCSV) e Groundnut ringspot virus (GRSV) em infecção mista

3.2 Análise de Ancestralidade do RNA M de Tomato chlorotic spot virus (TCSV) e Groundnut ringspot virus (GRSV)

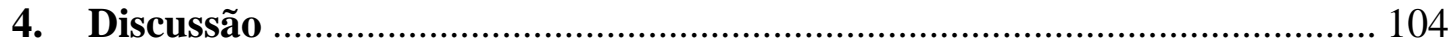

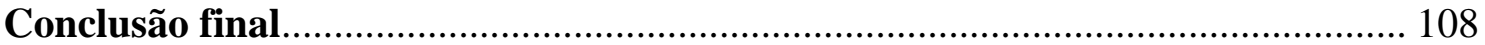

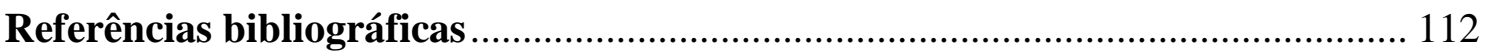




\section{Introdução}

\subsection{Histórico global das tospoviroses: da doença ao agente etiológico}

Na primeira metade do século XX foram frequentes os relatos de sintomas virais semelhantes, relacionados à diferentes doenças em plantas de fumo, tomateiro, batateira, abacaxizeiro, pimenteiras, alface e plantas ornamentais. Doenças conhecidas como 'vira-cabeça' no Brasil, 'spotted wilt' na Inglaterra, Austrália, Nova Zelândia e Estados Unidos, 'corcova' na Argentina, 'kromneck' na África do Sul e 'a mancha amarela do abacaxi' também nos Estados Unidos foram, por fim, associadas a um único agente etiológico, o vírus causador da doença 'spotted wilt' (Costa et al., 1941). Os sintomas descritos foram manchas anelares concêntricas, amarelas e pálidas nas folhas de tomateiro, abacaxizeiro e batateira; crestamento e enrolamento dos ponteiros; pontos necróticos nas folhas de fumo, batateira e tomateiro e manchas necróticas longitudinais no caule das mesmas plantas (Costa et al., 1941) (Figura 1, Figura 2).

(a)

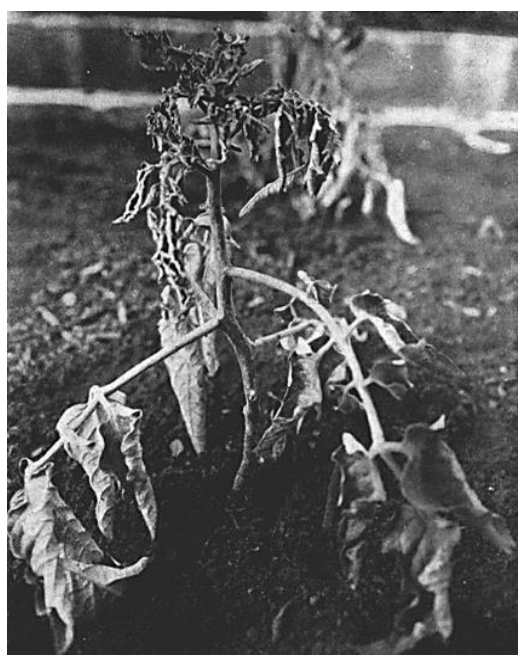

(b)

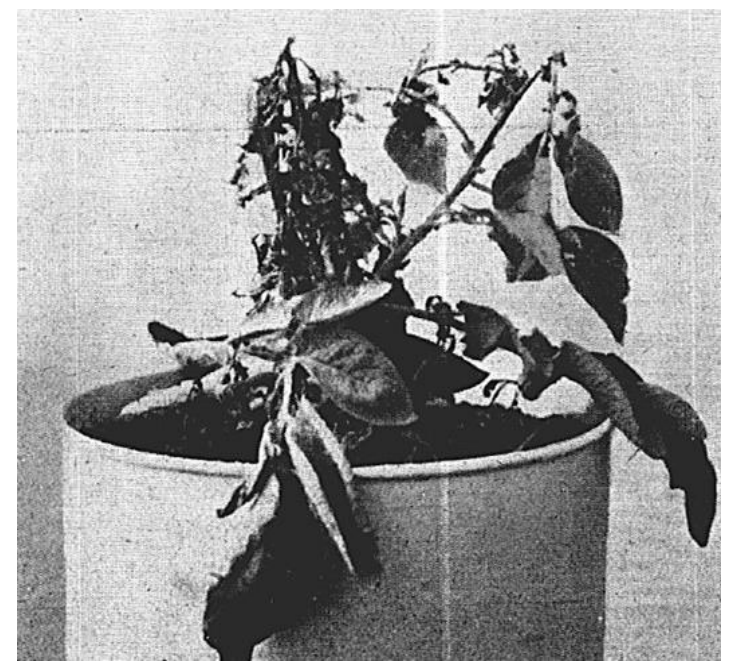

Figura 1. Tomateiro (a) e batateira (b) com crestamento do ponteiro e enrolamento foliar, causados pelo vírus 'spotted wilt'. Fonte: Costa et al., 1941. 
(a)

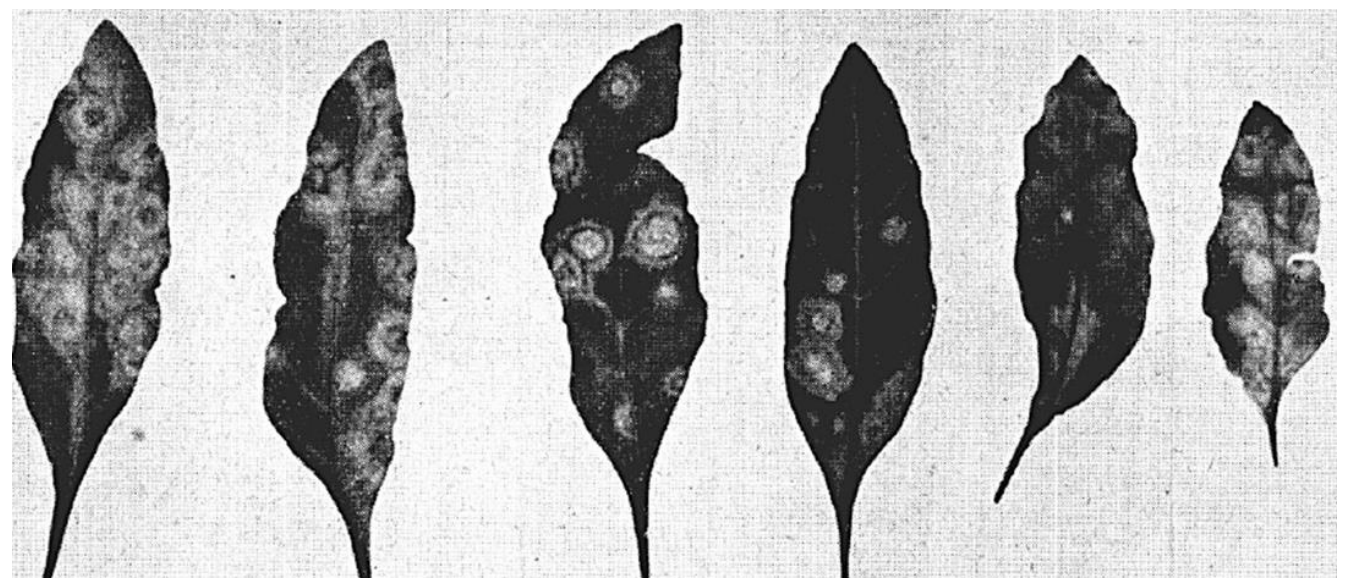

(b)
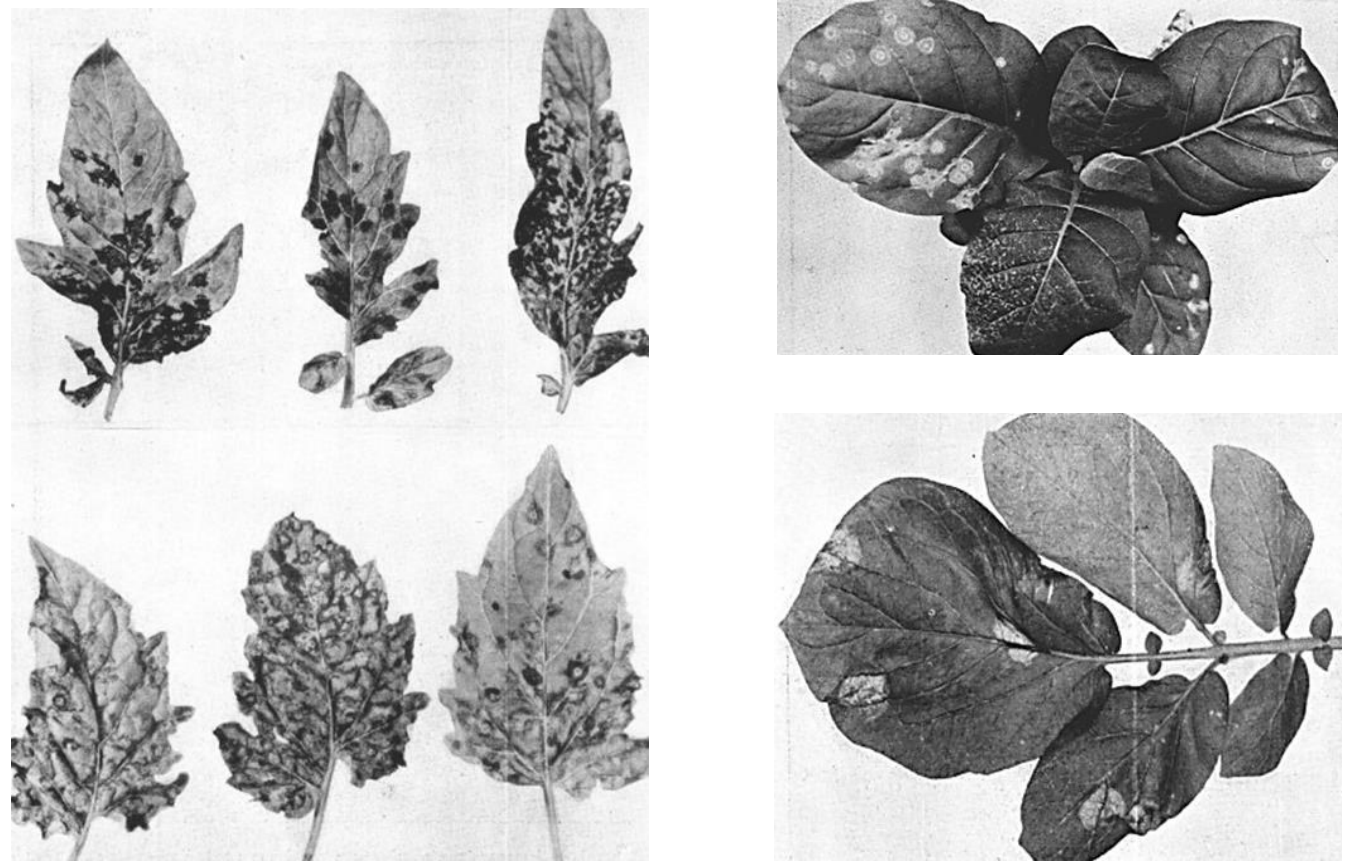

Figura 2. Folhas de pimenteira com manchas pálidas e anéis concêntricos (a) e folhas de tomateiro com anéis necróticos, fumo com manchas pálidas anelares e concêntricas e batateira com manchas pálidas (sentindo horário) (b) sintomas típicos de 'spotted wilt'. Fonte: Costa et al., 1941.

A doença 'spotted wilt' do tomateiro foi primeiramente descrita na Austrália em 1915 e o agente etiológico foi estabelecido posteriormente devido à transmissão da doença para plantas sadias utilizando o suco de plantas sintomáticas e por meio de insetos associados às culturas infectadas (Brittlebank, 1919; Pittman, 1927; Samuel et al., 1930). Insetos conhecidos como tripes foram relacionados à todas as epidemias ocorridas em distintas regiões da Austrália, tanto em cultivos protegidos quanto em cultivos em campo. As espécies de tripes Thrips tabaci (tripes da cebola) e Frankliniella insularis foram capazes de transmitir a doença 'spotted wilt' à plantas 
sadias, depois de se alimentarem de plantas doentes e continuarem infectando, mesmo após um longo período de alimentação apenas em plantas saudáveis. Assim, o causador da moléstia 'spotted wilt' foi reconhecido como de etiologia viral e denominado Tomato spotted wilt virus (TSWV), tendo os tripes (ordem: Thysanoptera) como insetos vetores (Pittman, 1927; Samuel et al., 1930).

A ocorrência da doença declinou na Europa Ocidental após a segunda guerra mundial, enquanto sua incidência crescia na Europa Oriental e no Brasil. Durante os anos de 1930 e 1940, T. tabaci foi considerado o principal vetor de TSWV, contudo, estudos posteriores demonstraram que a eficiência de transmissão de TSWV por $T$. tabaci esta diretamente relacionada ao hospedeiro que foi isolada a população, temperatura ambiental, ao sexo do inseto e ao isolado de TSWV, fatores esses que limitam a capacidade de transmitir o vírus e questionam a eficiência do vetor (Paliwal, 1974; Goldbach et al., 1994; Chatzivassiliou et al., 2002; Westmore et al., 2013). As populações de T. tabaci são separadas de acordo com o tipo de reprodução: populações arrhenotokus (reprodução sexuada) e populações thelyotokus (reprodução assexuada, ou partenogênese). Populações arrhenotokus são mais eficientes na transmissão de TSWV e foram as responsáveis pela disseminação do vírus pelos países do leste europeu na primeira metade do século XX, ao contrário dos países do oeste europeu e dos Estados Unidos, onde a população prevalente é a thelyotokus, a qual não demostra eficiência em transmitir o vírus. Esta perspectiva pode justificar o declínio da incidência de TSWV a partir dos anos de 1940 até 1980 (Goldbach et al., 1994; Chatzivassiliou et al., 2002; Kirk et al., 2003; Westmore et al., 2013).

A partir da década de 1980 a incidência de TSWV aumentou nos Estados Unidos, na Europa Ocidental e na Austrália, fato intimamente relacionado ao espalhamento do tripes Frankiniella occidentalis e sua eficiência como vetor de tospovírus. (Allen et al., 1986; Kirk et al., 2003; Ditzgen et al., 2005). Até 1960, F. occidentalis era amplamente encontrado apenas no lado oeste dos Estados Unidos e no México, ocorrendo uma única exceção na Nova Zelândia, onde uma população distinta ('lupin strain') foi relatada anteriormente às encontradas na América. Contudo, a população 'lupin strain' não foi associada a danos às grandes culturas, apesar de amplamente distribuída por todo país, sendo abundantemente encontrada na planta invasora Lupinus arboreus (Moud, 1983; Kirk et al., 2003). Populações distintas de F. occidentalis foram observadas nos Estados Unidos, sendo possível diferenciar as estirpes encontradas no campo e em casas de vegetação. Como meio de controle do 
tripes, o uso abusivo de inseticidas pode ter selecionado estirpes mais resistentes, que, juntamente com o aumento do trânsito de 'comodities' de origem vegetal no mundo a partir de 1960, contribuiu para disseminação de $F$. occidentalis para o restante do continente americano e os demais, favorecendo a dispersão de TSWV no mundo (Allen et al., 1986; Goldbach et al., 1994; Kiritani, 2001; Kirk et al., 2003).

Os constantes relatos de doenças causadas pelo vírus do 'spotted wilt' e a iminência de uma epidemia de TSWV, intensificaram as investigações sobre as características biológicas e moleculares do vírus. A composição estrutural de TSWV começou a ser desvendada a partir da segunda metade do século XX quando estudos em microscopia eletrônica mostraram que as partículas do vírus são encontradas no citoplasma da célula vegetal em agrupamentos rodeados por membranas com as mesmas características das citomembranas de células eucarióticas, sendo observados possíveis grânulos nessas vesículas similares aos ribossomos, sugerindo localização no lúmen do retículo endoplasmático. Além disso, pôde-se constatar que as partículas individuais eram circulares com diâmetro de 80-120nm e circundadas por uma camada externa (Kitajima, 1965; Kammen et al., 1966) (Figura 3).

O tipo de ácido nucleico que compõe o vírus foi determinado a partir de reações com os componentes químicos orcinol e difenilanima capazes de discriminar RNA e DNA, respectivamente. Dessa forma, o conteúdo interno da partícula reagiu na presença de orcinol e não reagiu quando em contanto com difenilamina, sinalizando a presença de RNA como o componente nucleico do core da partícula (Kammen et al., 1966). A composição proteica da partícula começou a ser definida em decorrência de uma série de experimentos com géis desnaturantes e o posterior tratamento das frações com marcadores químicos específicos e proteases. Ao menos sete proteínas foram isoladas, sendo quatro estruturais pré-estabelecidas. Polipeptídeos associados a glicolipídeos e ao ácido nucleico de partículas purificas de TSWV foram obtidos e após digestões proteolíticas das partículas intactas, não foi possível a detecção de três das quatro proteínas estruturais, indicando que essas compunham a membrana externa observada ao microscópio e que a única proteína ainda detectável estava provavelmente localizada no interior da partícula (Mohamed et al., 1973; Tas et al., 1977b). 
(a)

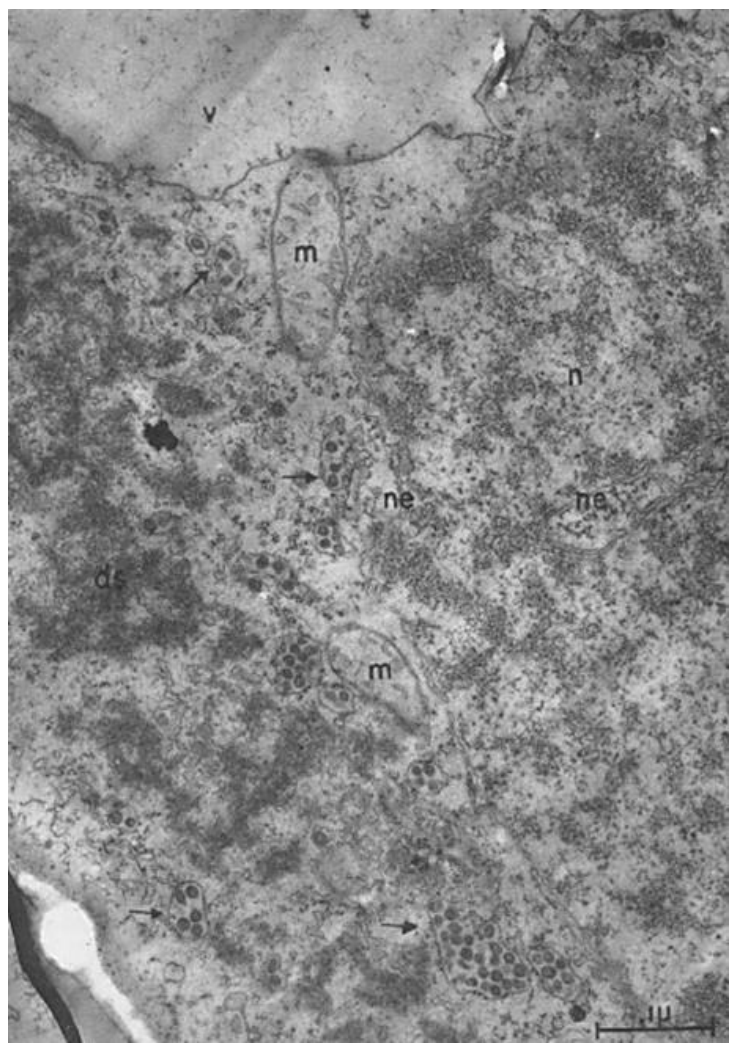

(b)
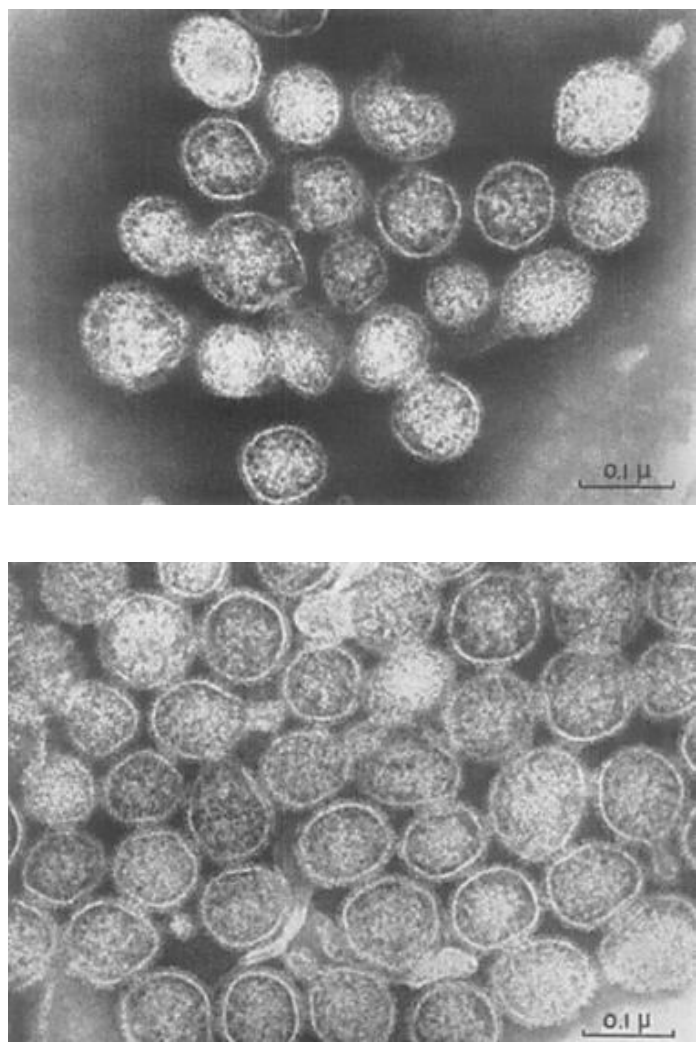

Figura 3. (a) Seção ultrafina de células do parênquima esponjoso de folhas de tabaco repletas de vesículas contendo partículas virais (setas pretas). $\mathrm{n}=$ núcleo; $\mathrm{m}=$ mitocôndria; ne = envelope nuclear; $\mathrm{v}=$ vacúolo; ds = fitas estrondensas. (b) Microscopia eletrônica das partículas individuais de TSWV purificadas de folhas de Nicotiana rustica. A membrana externa pode ser claramente observável. Fonte: Kitajima, 1965; Kammen et al., 1966.

Por meio de eletroforese com géis desnaturantes com variadas concentrações de agarose dos ácidos nucleicos extraídos de partículas purificadas de TSWV, quatro perfis de migração foram observados. Os materiais componentes dessas bandas foram tratados com RNAse e DNAse e submetidos à temperatura $\left(100^{\circ} \mathrm{C}\right)$, além de terem sido precipitados com LiCL (2M). Os componentes nucleicos que compunham três das quatro bandas encontradas ficaram intactos apenas na presença de DNAse, concluindose que a composição nucleotídica do core da partícula era de RNA fita simples (Hurck et al., 1977). O peso molecular das quatro bandas de RNA foi determinado, assim como o número de moléculas contidas nas bandas 1, 3 e 4 . Uma vez que, a banda 2 não pôde ser recuperada, foi sugerido que o core da partícula é composto por RNA segmentado. O peso molecular dessas moléculas de RNA foi de $1.1 \times 10^{6}, 1.7 \times 10^{6}$ e 2.7 x $10^{6}$, respectivamente (Hurck et al., 1977; Verkleij et al., 1982). Uma variação proporcional entre o RNA 1, RNA 3 e RNA 4 foi observada, ou seja, enquanto que em uma infecção inicial detecta-se mais RNA 3 para iguais proporções dos RNAs 1 e RNA 4, com a 
evolução da infecção pode-se perceber o acúmulo dos RNAs 1 e 4 e a queda no acúmulo do RNA 3, demonstrando que há uma dinâmica na demanda desses RNAs (Hurck et al., 1977). Além disso, a infectividade de diferentes frações proteicas obtidas das partículas de TWSV foi analisada. Assim, um componente infeccioso composto pela proteína encontrada no interior da partícula associada ao material genético foi isolado, sugerindo que tal proteína forma um complexo junto ao ácido nucleico (Mohamed et al., 1973; Tas et al., 1977b). A infectividade de TSWV não pôde ser associada às partículas intactas e tão pouco somente ao ácido nucleico, sugerindo que a proteína estrutural interna à partícula se trata de uma ribonucleoproteína (Mohamed et al., 1973; Hurck et al., 1977; Tas et al., 1977b).

As constantes falhas na detecção de infectividade nas preparações de RNA de TSWV levaram à conclusão de que os RNAs sozinhos não atuavam como mRNAs e, por isso, algum componente extra à transcrição era necessário ou alguma atividade de polimerase. Estas observações levantaram a hipótese sobre a possível orientação das moléculas de RNA associadas às partículas de TSWV, sugerindo que possuíssem orientação negativa (Mohamed et al., 1973; Hurck et al., 1977; Tas et al., 1977b). Observações posteriores questionaram essa hipótese, quando evidências mostraram que não há atividade transcriptase reversa associada às partículas purificadas de TSWV, muito menos às ribonucleoproteínas. Muitas proteínas foram diretamente transcritas in vitro, inclusive a nucleoproteína. Tais observações reforçaram a ideia de que os RNAs eram senso positivo, contudo a polaridade das moléculas ainda era incerta (Verkleij et al., 1982). Estudos de tradução in vitro demonstraram que a maioria dos polipeptídeos sintetizados a partir das frações recolhidas num gradiente de sacarose estavam sob orientação do RNA 3, o maior fragmento de RNA encontrado no interior da partícula, sinalizando que essa molécula é o principal fator de ativação da transcrição (Verkleij et al., 1982).

Apesar do desconhecimento da estrutura ribonucleoproteica de TSWV, as evidências de que o interior da partícula era composto por RNA trisegmentado associado à proteína estrutural de menor peso molecular encontrada no interior da partícula eram recorrentes (Mohamed et al., 1973; Hurck et al., 1977; Tas et al., 1977b; Mohamed, 1981; Verkleij et al., 1982). Três componentes distintos contendo a chamada proteína 1 com diferentes composições de RNA foram isolados da fração infecciosa, sendo altamente infectivos quando misturados (Mohamed, 1981). 
O entendimento da composição dos vírions de TSWV avançou. Então foi determinado que espécimes de TSWV eram compostas por partículas esféricas com diâmetro 80-120nm e uma membrana externa de glicoproteínas. O interior da partícula formado for três segmentos de RNA de fita simples com tamanhos diferentes: RNA S ('small'), RNA M ('medium') e RNA L ('large'), com aproximadamente 3400, 5200 e 8800 nucleotídeos, respectivamente. Inicialmente foi estabelecido que os vírions continham três proteínas estruturais distintas: uma interna $(\mathrm{N})$ de $29 \mathrm{kDa}$ e duas glicoproteínas de membrana de $78 \mathrm{kDa}(\mathrm{G} 1)$ e $58 \mathrm{kDa}(\mathrm{G} 2)$. Além dessas, uma quarta proteína de 110-220kDa era constantemente detectada no interior da partícula, porém em menor quantidade, sendo chamada de proteína L, ou 'large', por ser a de maior peso molecular (Mohamed et al., 1973; Tas et al., 1977b; Mohamed, 1981; Verkleij et al., 1983). A localização das regiões codantes das proteínas nos RNAs de TSWV começou a ser elucidada com a observação de vírus defectivos incapazes de formar partículas completas na célula hospedeira. Esse fenômeno pôde ser observado a partir de consecutivas passagens do vírus por meio de material infectado às plantas sadias. Após um determinado número de inoculações do suco foliar in planta, o vírus perdeu a capacidade de formar partículas completas, diminuindo gradativamente sua propriedade infectiva. O RNA de tamanho médio estava ausente nessa população viral defectiva, fato que relacionou esta a observação à codificação das proteínas de membrana componentes da partícula ao RNA M (Verkleij et al., 1983). Contudo, o conhecimento completo da organização genômica de TSWV foi finalizado no início dos anos de 1990 com a caracterização do RNA M (Kormelink et al., 1992b).

A polaridade das moléculas de RNA foi questionada até a demonstração que tanto o RNA S, quanto o RNA M, possuem duas sequencias abertas de leitura, ou 'Open Reading Frames' (ORFs), e que em ambos os casos, os genes são transcritos em orientações diferentes, ou seja, os RNAs S e M codificam proteínas no sentido viral e no viral complementar; e, que no RNA L há apenas uma ORF no sentido viral complementar (de Haan et al., 1990; de Haan et al., 1991; Kormelink et al., 1992b; Poelwijk et al., 1993).

A demonstração de que as sequencias terminais dos RNAs $S$ e $M$ são complementares e juntamente com o fato de TSWV ser composto por RNA trisegmentado fez surgir a primeira evidência de que o vírus do 'spotted wilt' não poderia ser membro solitário de um grupo de vírus e sim componente de uma grande família de vírus transmitidos por insetos, a família Bunyaviridae (Bishop et al., 1980; de 
Haan et al., 1989). A complementariedade terminal das moléculas de RNA possibilita a formação de estrutura do tipo 'panhadle' e moléculas pseudocirculares, que estão fortemente associadas à proteína do nucleocapsídeo (N) (de Haan et al., 1989; Kormelink et al., 1992c; Richmond et al., 1998; Uhrig et al., 1999). A complementariedade dos segmentos de TSWV foi comprovada para as três moléculas de RNA. Além disso, observou-se que os sete primeiros nucleotídeos de cada molécula (5' AGAGCAA 3') eram idênticos e que no meio da sequência nucleotídica dos RNAs S e M há uma região rica em uracila e adenina capaz de se complementar e dobrar a molécula de RNA em uma estrutura de grampo ('hairpin') (de Haan et al., 1989; de Haan et al, 1990; de Haan et al, 1991; Kormelink et al., 1992b) (Figura 4). 
(a)
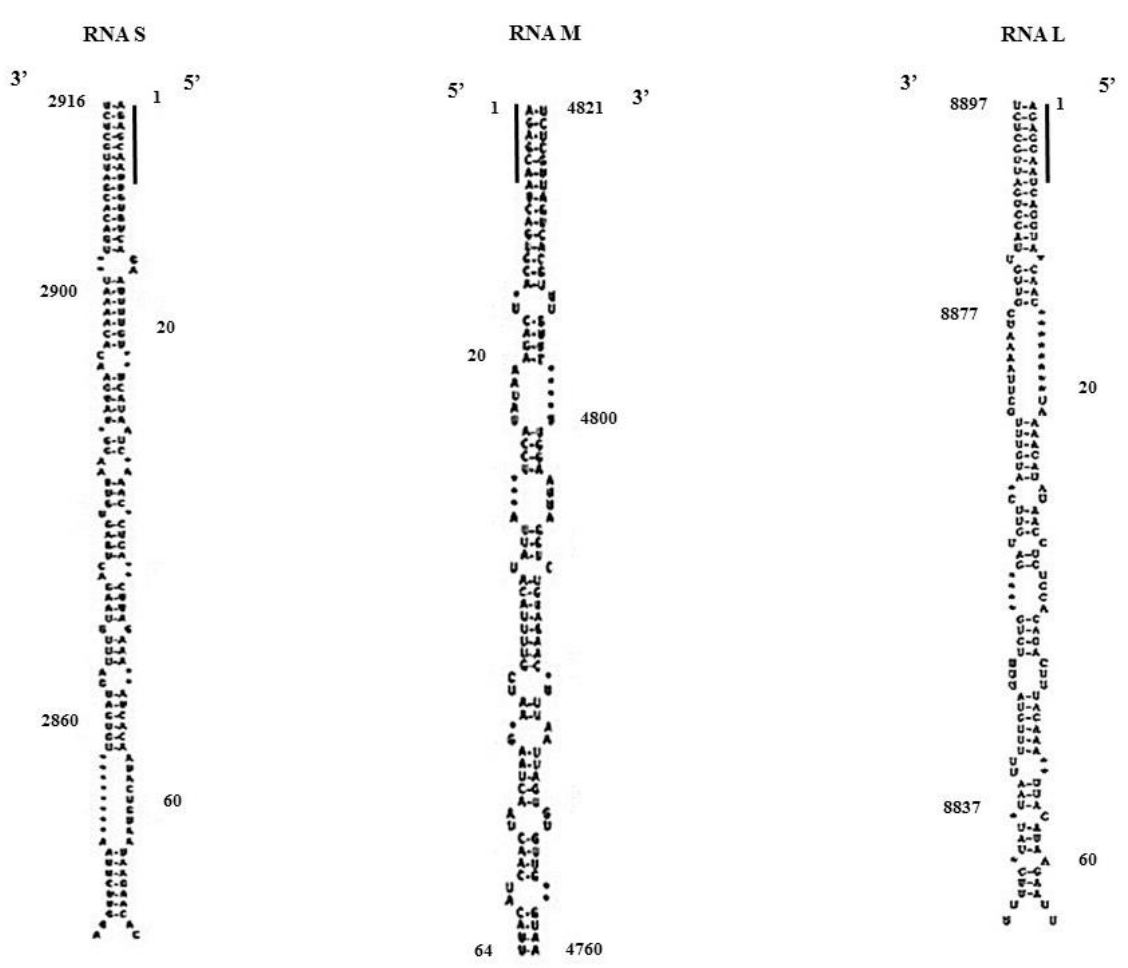

(b)
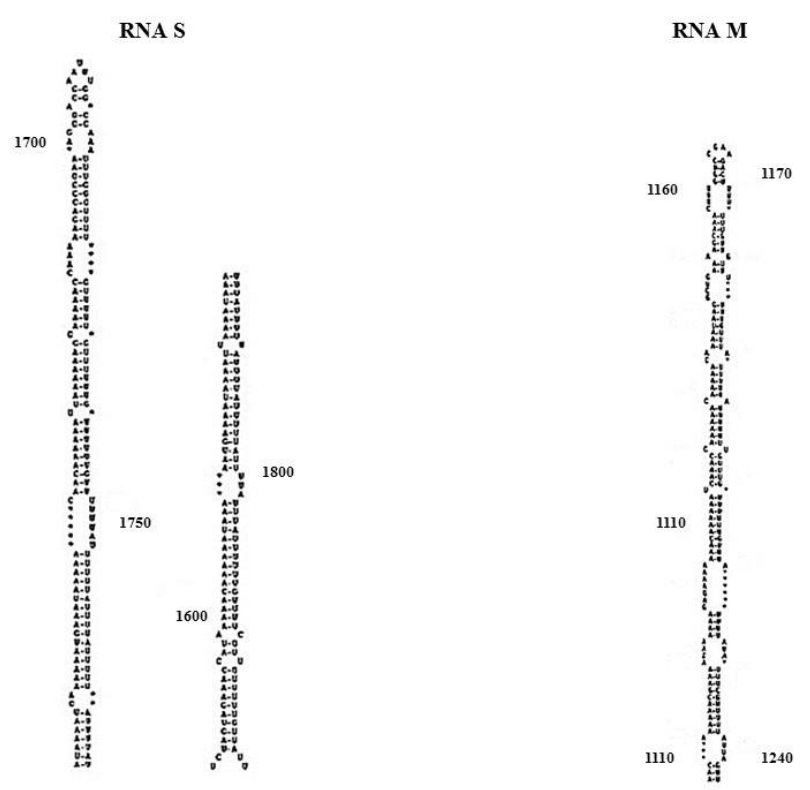

Figura 4. Estruturas secundárias formadas nos RNAs de TSWV. (a) 'Panhandle' formado pela complementariedade das sequências terminais dos segmentos S, M e L; a barra preta sinaliza os sete nucleotídeos idênticos nos três segmentos. (b) 'Hairpin' formado pelo dobramento das da região intergência rica em A e U dos RNAs S e M. Fonte: de Haan et al, 1990; de Haan et al, 1991; Kormelink et al., 1992b. 
O RNA S com estratégia de expressão gênica denominada ambisenso e aproximadamente 3100 nucleotídeos codifica a ribonucleoproteína (29kDa) estrutural no sentido viral complementar (vc) e uma segunda proteína não estrutural no sentido viral (v) que foi chamada de NSs (52kDa) ('nonstructural protein of S RNA') que é responsável pela supressão do silenciamento gênico na planta infectada, favorecendo a infecção viral e não apresenta nenhuma homologia com outras proteínas não estruturais do RNA S de outros membros da família Bunyaviridae (de Haan et al., 1990; Bucher et al., 2003). O RNA M com aproximadamente 5400 bases também codifica duas proteínas em ambos sentidos: no sentindo viral complementar (vc), a proteína estrutural precursora das glicoproteínas G1 (46kDa) e G2 $(75 \mathrm{kDa})$ componentes da partícula e também responsável pela interação vírus-vetor e, no sentido viral (v), uma proteína não estrutural responsável pelo movimento célula-a-célula e, consequentemente, à infecção sistêmica, denominada NSm (34kDa) ('nonstructural protein of M RNA') (Koermelink et al., 1992b; Kormelink et al., 1994; Storms et al., 1995; Bandla et al., 1998). O RNA L é a maior molécula com quase 8800 nucleotídeos e apenas uma ORF no sentido viral complementar codificadora da polimerase viral (332kDa) (Figura 5). Apesar de o RNA L não possuir aparentes singularidades como seus cognatos S e M, uma característica muito importante foi observada nessa molécula: a capacidade natural de formar moléculas mutantes em condições artificiais, conhecidas como defectivos interferentes (DIs) de função ainda desconhecida (de Haan et al., 1991; Resende et al., 1991b; Poelwijk et al., 1993; Inoue-Nagata et al., 1998). 
(a)

\section{RNA S}

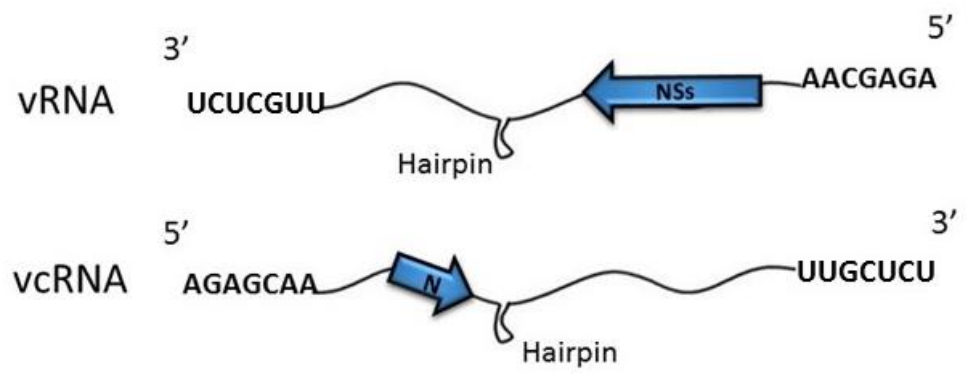

(b)

RNA M
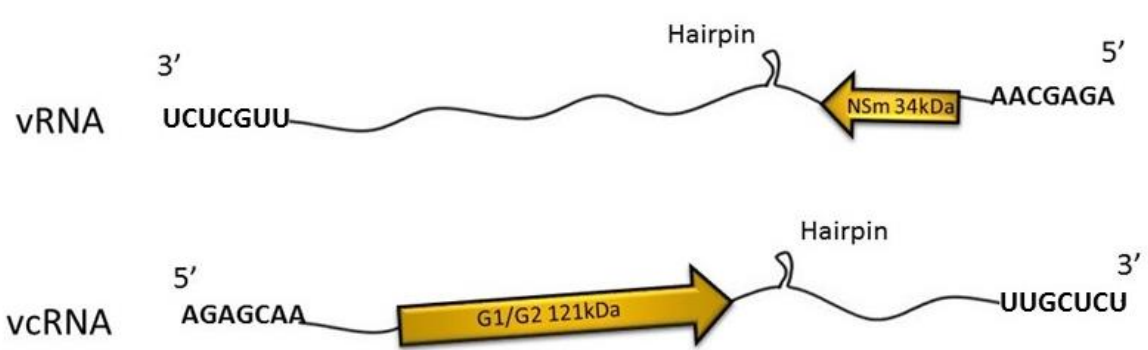

(c)

RNA L

$5^{\prime}$

vCRNA AGAGCAA

Figura 5. Esquema organização genômica de TSWV. (a) RNA S com aproximadamente 3100 nucleotídeos codifica a ribonucleoproteína $\mathrm{N}(29 \mathrm{kDa})$ na fita viral complementar (vcRNA) e a NSs (52kDa) na fita viral (vRNA). (b) RNA M com aproximadamente 5400 bases codifica a proteína precursora das glicocoproteínas G1 (46kDa) e G2 $(75 \mathrm{kDa})$ na fita viral complementar (vcRNA) e a proteína não estrutural NSm $(34 \mathrm{kDa})$ na fita viral (vRNA). (c) RNA L com aproximadamente 8800 nucleotídeos possui apenas a ORF da polimerase (332kDa) na fita viral (vRNA). 
A caracterização do genoma e estrutura de TSWV foi finalizada e com ela soube-se mais sobre a posição taxonômica do vírus. Similaridades estruturais da partícula, organização genômica do tipo RNA trisegmentando linear de fita simples, associado à nucleoproteína, com polaridade senso negativa e positiva (ambisenso) e homologia significante da glicoproteína G1 de TSWV com membros do gênero Bunyavirus (família Bunyaviridae) foram evidenciadas (Figura 6). Estes fatores, associados às diferenças, tanto nas sequências de aminoácidos, quanto de nucleotídeos com os demais membros da família, justificaram a proposta de inclusão de Tomato spotted wilt virus (TSWV) em um novo gênero da família Bunyaviridae (de Haan et al., 1989; de Haan et al, 1990; de Haan et al, 1991; Kormelink et al., 1992b). Dessa forma, em 1990, o Comitê Internacional de Taxonomia Viral (ICTV) incluiu Tomato spotted wilt virus (TSWV) como membro único e espécie tipo do recém-criado gênero Tospovirus na família Bunyaviridae, sendo o único gênero do grupo composto por vírus que infectam plantas (Francki et al., 1991; Kormelink et al., 1992b). Assim, o gênero Tospovirus passou a integrar a família Bunyaviridae juntamente com outros quatro gêneros de vírus que infectam animais: Orthobunyavirus, Phlebovirus, Hantavirus e Nairovirus (King et al., 2012).

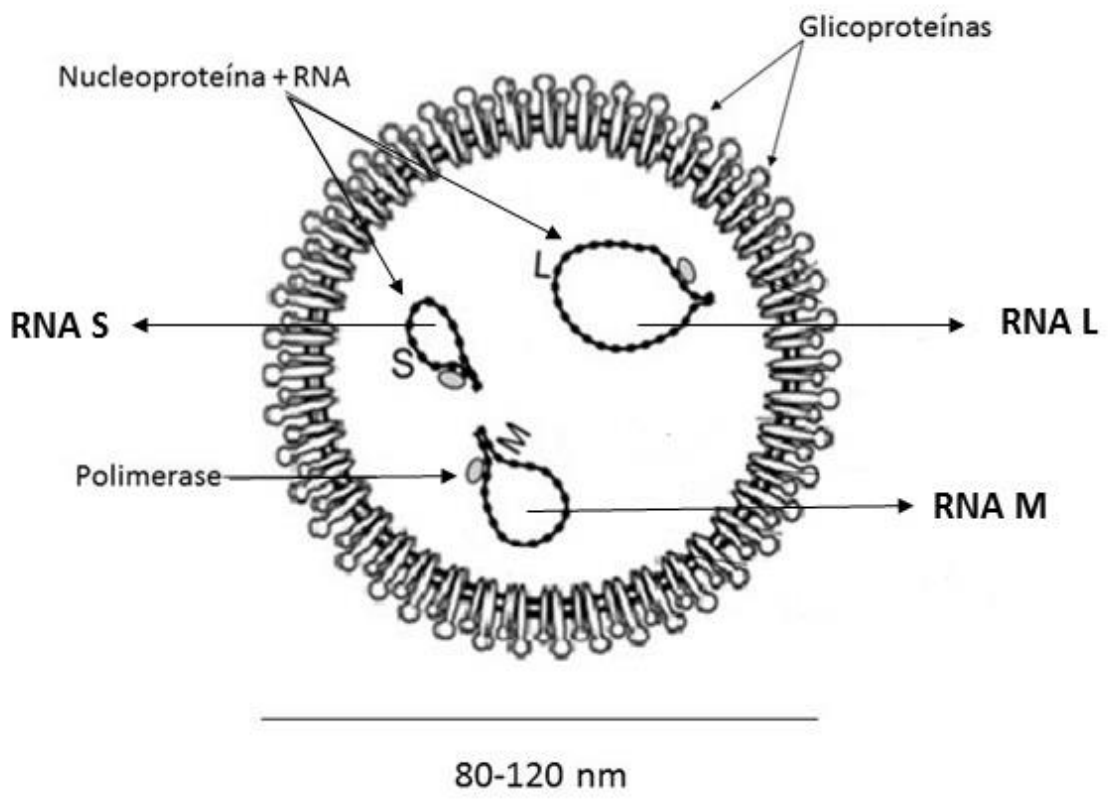

Figura 6. Representação esquemática da partícula dos integrantes da família Bunyaviridae. As três moléculas de RNA (S RNA, M RNA e L RNA) associadas à nucleoproteína são arranjadas dentro de uma partícula esférica $(80-120 \mathrm{~nm})$ envelopada, que possui uma camada externa de glicoproteínas. 
Com os avanços nos estudos moleculares de TSWV, foi possível ampliar o conhecimento epidemiológico do vírus, com um maior entendimento sobre a disseminação dos isolados de tospovirus coletados em diversas parte do mundo, sendo produzidos anticorpos monoclonais e policlonais e diversos tipos de anti-soros para tal finalidade (Tas et al., 1977a; Law et al., 1990; de Ávila et al., 1990; Wang et al., 1990; Adam et al., 1991; Resende et al., 1991a; de Ávila et al., 1993b). Isolados de diferentes regiões geográficas foram analisados, ficando evidente que poderiam ser agrupados em diferentes sorogrupos e, consequentemente, diferentes sorotipos (Tabela 1). Dessa forma, três sorogrupos e dois sorotipos foram determinados (de Ávila et al., 1990; Elliot, 1990; de Ávila et al., 1992; de Ávila et al., 1993b). Entende-se por serogrupo isolados que reagem de forma semelhante a antissoros policlonais, e serotipos são separados por diferenças antigências, via anticorpos monoclonais, entre as proteínas $\mathrm{N}$ de isolados de um mesmo serogrupo, por ser essa proteína menos conservada do que as outras encontradas em TSWV (de Ávila et al., 1990; Law et al., 1991; de Ávila et al., 1993b).

Tabela 1. Região geográfica (país) e plantas hospedeiras dos isolados de Tomato spotted wilt virus (TSWV) analisados por serologia com anticorpos policlonais

\begin{tabular}{ccc}
\hline Isolado & País & Cultura \\
\hline $\mathrm{A} 1 \bullet$ & Alemanha & Ranunculus \\
$\mathrm{A} 4 \bullet$ & África do Sul & Ervilha \\
$\mathrm{A} 7 \bullet$ & Iugoslávia & Tabaco \\
$\mathrm{B} 1 \bullet$ & Brasil & Ervilha \\
$\mathrm{B} 2 \bullet$ & Brasil & Tomate \\
$\mathrm{B} 5 \bullet$ & Brasil & Tomate \\
$\mathrm{B} 13 \bullet$ & Brasil & Tomate \\
$\mathrm{B} 15 \bullet$ & Brasil & Tomate \\
$\mathrm{B} 16 \bullet$ & Brasil & Tomate \\
$\mathrm{CNPH} \bullet$ & Brasil & Tomate \\
$\mathrm{Fi} \bullet$ & Finlândia & Tomate \\
$\mathrm{H} 1 \bullet$ & Países Baixos & Impatiens spp. \\
$\mathrm{H} 2 \bullet$ & Países Baixos & Tomate \\
$\mathrm{H} 3 \bullet$ & Países Baixos & Tomate \\
$\mathrm{H} 4 \bullet$ & Países Baixos & Crisântemo \\
$\mathrm{S} 1 \bullet$ & Espanha & Batata doce \\
$\mathrm{B} 3 \bullet \bullet$ & Brasil & Tomate \\
$\mathrm{B} 6 \bullet$ & Brasil & Tomate \\
$\mathrm{A} 5 \bullet$ & África do Sul & Amendoim \\
$\mathrm{A} 8 \bullet \bullet$ & Brasil & Tomate \\
$\mathrm{H} 7 \bullet \bullet$ & Países Baixos & Impatiens spp.
\end{tabular}

Fonte: de Ávila et al., 1990; de Ávila et al., 1992.

- Isolados do sorogrupo I

-• Isolados do sorogrupo II

••• Isolados do sorogrupo III

Sete isolados representantes dos três serogrupos pré-determinados foram analisados mais profundamente (Tabela 2). Todos os isolados testados se diferenciaram no tempo de incubação e severidade de sintomas. Os sintomas observados na época 
foram os típicos causados pelo vírus do 'spotted wilt': anéis cloróticos e necróticos, seguido por necrose das nervuras, mosqueado nas folhas, deformação e necrose dos ponteiros. Todos os isolados estudados exibiram efeitos citopatológicos similares (de Ávila et al., 1993b). Partículas de todos os isolados foram encontradas em cavidades circundadas por membranas do retículo endoplasmático, e partículas maduras foram observadas em aglomerados ('clusters'). Apenas o isolado BR-08 pôde ser encontrado a maior parte das vezes separadamente dentro das vesículas. O isolado NL-7 não infectou sistemicamente solanáceas típicas suscetíveis à TSWV (Datura stramonium, tomate, Nicotiana tabacum), causando apenas lesões locais nas folhas inoculadas, mesmo infectando severamente Nicotiana benthamiana. Todos os isolados causaram sintomas sistêmicos em Impatiens spp., contudo o isolado NL-7 foi mais agressivo (de Ávila et al., 1990; de Ávila et al., 1992).

Tabela 2. Classificação sorológica (via anticorpos monoclonais), notação e origem de sete isolados de Tomato spotted wilt virus (TSWV)

\begin{tabular}{lcccc}
\hline \multirow{2}{*}{ Serogrupo } & \multicolumn{2}{c}{ Notação } & \multicolumn{2}{c}{ Origem } \\
\cline { 2 - 5 } & Antiga & Nova & País & Cultura \\
\hline I & CNPH $_{1}$ & BR-01 & Brasil & Tomate \\
& S1 & E-01 & Espanha & Pimenta \\
II Serotipo I & B3 & BR-03 & Brasil & Tomate \\
& B6 & BR-06 & Brasil & Tomate \\
\multicolumn{1}{c}{ Serotipo II } & A5 & SA-05 & África do Sul & Amendoim \\
III & B8 & BR-08 & Brasil & Tomate \\
\hline
\end{tabular}

Fonte: de Ávila et al., 1990; de Ávila et al., 1992; de Ávial et al., $1993 b$.

Os membros do serogrupo III eram totalmente distintos dos outros presentes nos serogrupos I e II, não apresentando nenhum tipo de reação cruzada com os anticorpos capazes de detectar os isolados dos outros dois grupos e com sintomatologia totalmente distinta. Tais observações reforçaram a ideia de que os isolados do serogrupo I e III eram espécies diferentes no gênero Tospovirus, sendo denominadas Tomato spotted wilt virus (TSWV) e Impatiens necrotic spot virus (INSV), respectivamente (de Ávila et al., 1992; Law et al., 1991; de Ávila et al., 1993b). Ainda por meio dos estudos com antissoros policlonais e anticorpos específicos, pôde-se perceber que os membros dos 
serogrupos I e II eram menos divergentes, além disso, os componentes do grupo II não apresentavam identidade nucleotídica da proteína $\mathrm{N}$ de quase $100 \%$ entre si, como observado para os isolados dos outros grupos, ficando claro que havia dois subgrupos (serotipos) e que eram distintos de TSWV (serogrupo I) e INSV (serogrupo III), podendo representar duas novas espécies. Assim, outro fator de classificação surgiu na determinação de espécies no gênero Tospovirus, a identidade das sequências da proteína N (de Ávila et al., 1990; de Ávila et al., 1993b).

Os estudos sorológicos e moleculares dos isolados demonstraram que características fenotípicas (citopatologia, sintomatologia, composição da partícula, tamanho dos RNAs) não poderiam ser utilizadas na descriminação de espécies, apenas na definição do gênero Tospovirus (de Ávila et al., 1990; Law et al., 1991; de Ávila et al., 1993b). Dessa forma, as propriedades antigênicas da proteína $\mathrm{N}$ passaram a ser um importante critério de determinação de espécies no gênero Tospovirus, como já ocorria com os outros integrantes da família Bunyaviridae (de Ávila et al., 1993a; de Ávila et al., 1993b; Elliot, 1990). As sequências nucleotídica e de aminoácido da proteína $\mathrm{N}$ de isolados de tospovírus foram comparadas e utilizadas na separação de espécies, por serem suficientemente divergentes entre si (Tabela 3). Os isolados do serogrupo I e III foram bastante divergentes ( $55 \%$ identidade nucleotídica) como já havia sido observado nos estudos sorológicos. Isolados do serogrupo II tiveram uma variação intermediária (57-75\% identidade nucleotídica) quando comparados com os isolados dos grupos I e III, mas apresentaram uma diferença significativa entre os isolados do grupo. Enquanto que isolados dos grupos I e III tiveram 100\% de identidade entre si, os isolados do grupo II apresentaram $82 \%$ de identidade. Estes dados levaram à proposta de duas novas espécies: Tomato chlorotic spot virus (TCSV) e Groundnut ringspot virus (GRSV), ambas pertencentes ao serogrupo II, já que já havia sido reconhecido que os isolados do serogrupo I pertenciam à espécie TSWV e os isolados do serogrupo III à INSV (de Ávila et al., 1992; de Ávila et al., 1993a; de Ávila et al., 1993b) (Tabela 4). Assim, as relações sorológicas da proteína $\mathrm{N}$ e o grau de identidade de sua sequência de aminoácidos tornaram-se importantes fatores na demarcação de espécies do gênero Tospovirus (de Ávila et al., 1993a; King et al., 2012). 
Tabela 3. Identidade (\%) das sequencias nucleotídicas e proteicas de quatro isolados de Tomato spotted wilt virus TSWV (serogrupo I) comparados com isolados de outros serogrupos

\begin{tabular}{cccc}
\hline Isolado & $\begin{array}{c}\text { BR-03 } \\
(\text { Serogrupo II })\end{array}$ & $\begin{array}{c}\text { SA-05 } \\
(\text { Serogrupo II })\end{array}$ & $\begin{array}{c}\text { NL-07 } \\
(\text { Serogrupo III })\end{array}$ \\
\hline $\begin{array}{c}\text { BR-01 } \\
\text { (serogrupo I) }\end{array}$ & $74.2(\mathrm{nt})$ & $75.9(\mathrm{nt})$ & $55.9(\mathrm{nt})$ \\
$76.4(\mathrm{aa})$ & $78.2(\mathrm{aa})$ & $55.4(\mathrm{aa})$ \\
$\begin{array}{c}\text { BR-03 } \\
(\text { Serogrupo II) }\end{array}$ & $82.1(\mathrm{nt})$ & $57.6(\mathrm{nt})$ \\
& $81.0(\mathrm{aa})$ & $56.0(\mathrm{aa})$ \\
$\begin{array}{c}\text { SA-05 } \\
\text { Serogrupo II) }\end{array}$ & & $57.3(\mathrm{nt})$ \\
\end{tabular}

Fonte: de Ávila et al., 1993a.

Tabela 4. Classificação por espécie de isolados do gênero Tospovirus baseada em testes sorológicos e nas identidades de sequências de nucleotídeos e aminoácidos da proteína do nucleocapsídeo $(\mathrm{N})$

\begin{tabular}{|c|c|}
\hline Isolado & Espécies de Tospovirus \\
\hline $\begin{array}{c}\text { BR-01 } \\
\text { (serogrupo I) }\end{array}$ & Tomato spotted wilt virus (TSWV) \\
\hline $\begin{array}{c}\text { BR-03 } \\
\text { (Serogrupo II) }\end{array}$ & Tomato chlorotic spot virus (TCSV) \\
\hline $\begin{array}{c}\text { SA-05 } \\
\text { (Serogrupo II) }\end{array}$ & Groundnut ringspot virus (GRSV) \\
\hline $\begin{array}{c}\text { NL-07 } \\
\text { (Serogrupo III) }\end{array}$ & Impatiens necrotic spot virus (INSV) \\
\hline
\end{tabular}

\subsection{Genoma e biologia de tospovírus}

Após o sequenciamento completo do genoma de TSWV, foi possível determinar a organização genômica dos membros do gênero. Os tospovírus são vírus de RNA trisegmentado de fita simples, organizados em partículas esféricas de $80-120 \mathrm{~nm}$ de diâmetro, as quais são envelopadas por uma membrana de glicoproteínas. Os três RNAs possuem tamanhos variados e por isso foram denominados RNA L ('large'), RNA M ('medium') e RNA S ('small'). As sequências 5' e 3' terminais de todos os RNAs são conservadas, e juntos os três RNAs codificam cinco ORFs ('open reading frames'). As extremidades conservadas são complementares, possibilitando a formação de moléculas pseudocirculares (de Haan et al, 1990; de Haan et al, 1991; Kormelink et al., 1992b). O interior da partícula é composto por diferentes concentrações das fitas virais e virais 
complementares dos três RNAs que estão fortemente associados à uma nucleoproteína e também a unidades prontas da polimerase (Mohamed et al., 1973; Tas et al., 1977; de Haan et al., 1989; Kormelink et al., 1992c) (Figura 6).

O RNA L possui em torno de $9 \mathrm{~kb}$ é senso negativo e codifica apenas uma ORF que apresenta motivos de polimerases dependentes de RNA, contudo, provavelmente se trata de uma proteína multifuncional de aproximadamente $332 \mathrm{kDa}$, que além da atividade polimerase, pode atuar como endonuclease, transcriptase e helicase (de Haan et al., 1991; Poelwick et al., 1993; Adkins et al., 1995; Duijsings et al., 2001; Chapman et al., 2002; Knippenberg et al., 2005). O RNA M com aproximadamente 5.5kb é ambisenso e possui duas ORFs, uma na fita viral que codifica a proteína não estrutural NSm (34kDa) responsável pelo movimento célula-célula e a outra na fita viral complementar que codifica o precursor das glicoproteínas G1 (46kDa) e G2 (75kDa) da membrana que engloba a partícula e são responsáveis pela interação com o vetor (Kormelink 1992b; Kormelink et al., 1994; Badla et al., 1998). O RNA S tem pouco mais de $2.9 \mathrm{~kb}$ é ambisenso e possui duas ORFs: uma no sentido viral complementar que codifica a proteína estrutural $\mathrm{N}$ do nucleocapsídeo e outra no sentido viral que codifica a proteína não estrutural NSs, responsável pela supressão do silenciamento gênico na planta (de Haan et al., 1990; Kormelink et al., 1991; Bucher et al., 2003; Margaria et al., 2007).

A transcrição primária das proteínas dos tospovírus inicia-se com a síntese dos mRNAs subgenômicos das fitas virais e virais complementares dos RNAs $\mathrm{S}$ e $\mathrm{M}$ e do mRNA do segmento L pela polimerase viral em um sistema de 'cap-snatching'. Neste sistema, "primers" são formados a partir de mRNAs do hospedeiro para iniciar a transcrição (Knippenberg et al., 2005) (Figura 7). Regiões não específicas da porção 5' desses mRNAs ligam-se às extremidades 3' dos vírus e por meio da ação de endonucleases virais os mRNAs dos doadores dos primers (doadores 'cap') são clivados logo no início da sequência 5' (nucleotídeos 1 ou 2) onde começa a elongação do mRNA viral (Kormelink et al., 1992a; Poelwijk et al., 1996; Kormelink et al., 1992c; Duijsings et al., 1999; Duijsings et al., 2001; Knippenberg et al., 2005). Os mRNAs virais possuem sequencias heterólogas do hospedeiro na extremidade 5', formando uma estrutura do tipo ‘cap' que pode ser um sítio de ligação da proteína $\mathrm{N}$, protegendo essas moléculas e evitando que atuem como doadores de primers na transcrição ('resnatching') (Kormelink et al., 1992a; Poelwijk et al., 1996; Knippenberg et al., 2005; Geerts-Dimitriadou et al, 2012) (Figura 7). As estruturas secundárias presentes nas regiões intergênicas dos RNAs S e M ainda são de função desconhecida, contudo, 
atuam como cofatores da transcrição, pois a deleção de tais regiões impossibilita a transcrição dos mRNAs (Geerts-Dimitriadou et al, 2012; Clabbers et al., 2014). Motivos conservados nas estruturas das regiões intergênicas de tospovírus e outros vírus sinalizam que há seleção positiva dessas estruturas em diversos grupos virais (Clabbers et al., 2014).
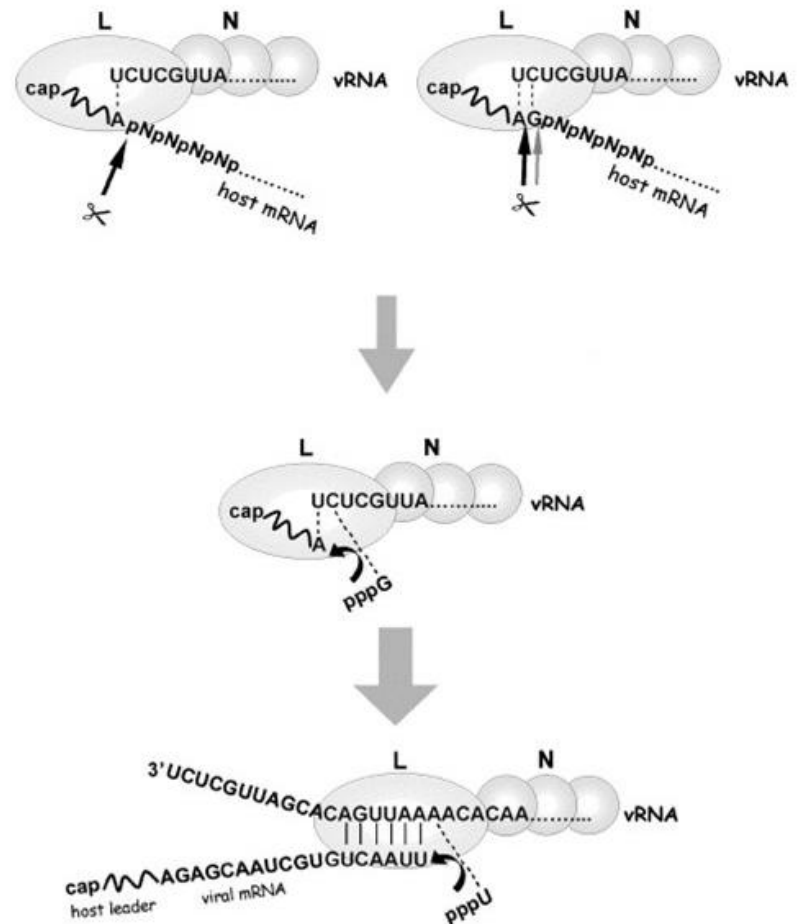

Figura 7. Modelo da transcrição por 'cap-snatching' de tospovírus. Após o alinhamento do mRNA do hospedeiro (doador 'cap') ao template viral, uma endonuclease cliva a porção 5' do doador 'cap' na primeira ou segunda base pareada, seguindo com a elongação do mRNA viral. L: polimerase; N: nucleoproteína; 'host mRNA': RNA mensageiro do hospedeiro; 'viral mRNA': RNA mensageiro viral; 'host leader': sequência do hospedeiro destinada ao processo de 'cap-snatching'. Fonte: Knippenberg et al., 2005.

As proteínas N, G1, G2 e NSs são compartimentalizadas em distintas inclusões no citoplasma. Análises de cortes ultrafinos de células infectadas com TSWV por imunohistoquímica demonstraram que a proteína $\mathrm{N}$ é acumulada no viroplasma (região de massa densa devido ao acúmulo dos RNAs virais), local onde, provavelmente, ocorre a associação do RNA com a proteína do nucleocapsídeo, pois agregados de nucleocapsídeos são encontradas na periferia dos viroplasmas (Ullman et al., 1995; Kikkert el al., 1999). Em membranas paralelas formadas a partir da separação de cisternas no complexo de Golgi são encontradas predominantemente as proteínas da camada glicoproteica. Essas membranas apresentam junções com o retículo 
endoplasmático e também são localizadas adjacentes ao viroplasma, embebidos em uma única massa densa, o que sugere regiões diferentes de uma mesma compartimentalização celular (Ullman et al., 1995; Kikkert el al., 1999). As proteínas da NSs são acumuladas em inclusões fibrosas no citoplasma (Kormemlink et al., 1991; Ullman et al., 1995).

A morfogênese da partícula inicia-se com o dobramento das membranas paralelas do Golgi fundidas ao retículo endoplasmático e dispersas no citoplasma ao redor dos agregados de nucleocapsídeos adjacentes, formando partículas com duplo envelope. Essas partículas fundem-se umas às outras gerando aglomerados de partículas com apenas um envelope ('clusters'). As partículas com envelope dupla também podem se fundir com o retículo endoplasmático, criando sacos cheios de partículas maturadas de tospovírus (Kikkert el al., 1999) (Figura 8). A formação das membranas paralelas derivadas do complexo de Golgi e de membranas do retículo endoplasmático é induzida pelas glicoproteínas dos tospovírus, pois a proteína G1 apresenta domínio transmembrânico e é responsável pelo recrutamento da proteína G2 no processo de formação da partícula (Snippe et al., 2007; Ribeiro et al., 2008). Quando expressadas separadamente, G1 é encontrada no retículo endoplasmático e no complexo de Golgi, enquanto que, G2 é encontrada apenas no retículo endoplasmático. Porém, quando são coexpressadas ambas são localizadas em regiões de exportação do retículo endoplasmático e depois no complexo de Golgi. As glicoproteínas também possuem a capacidade de induzir deformações de membranas, o que justifica a formação esférica envelopada das partículas virais (Ribeiro et al., 2008). 


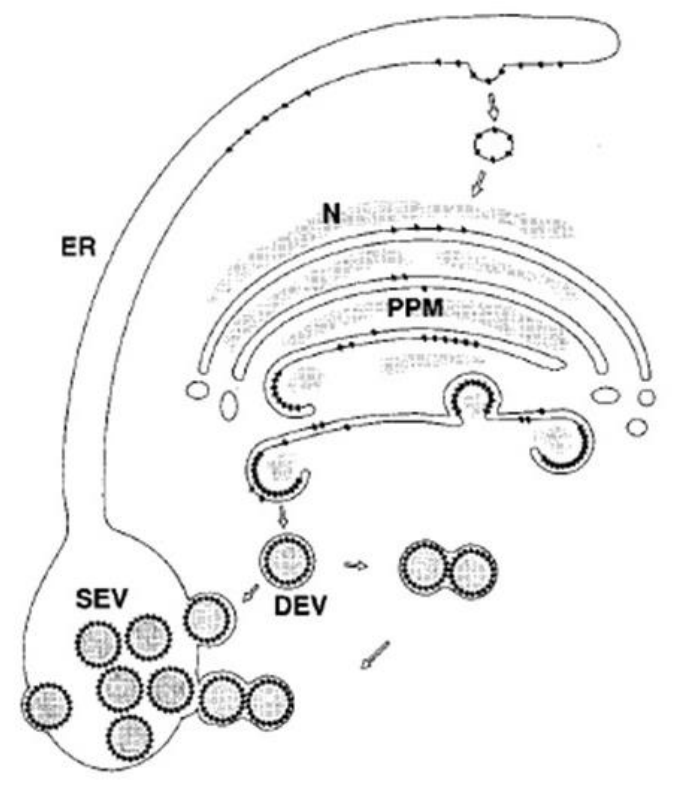

Figura 8. Modelo da morfogênese das partículas de Tomato spotted wilt virus (TSWV). ER = retículo endoplasmático; $\mathrm{SEV}=$ partículas envelopadas; $\mathrm{DEV}=$ partículas duplamente envelopadas; $\mathrm{N}=$ nucleoproteínas. Fonte: Kikkert et al., 1999.

A nucleoproteína tem afinidade por ssRNA e, apesar de não possuir uma sequência específica de ligação, diversos motivos para tal associação foram caracterizados (Richmond et al., 1998). A falta de uma sequência específica de ligação aos RNAs sugere que essa proteína pode desempenhar diversas funções durante a infecção viral, principalmente na interação com outras proteínas codificadas pelo vírus, como a proteína de movimento NSm, a polimerase e as glicoproteínas, atuando na regulação da replicação e montagem da partícula (Storms et al., 1995; Richmond et al, 1998; Uhrig et al., 1999; Kikkert el al., 1999). No empacotamento da molécula de RNA as nucleoproteínas associam-se umas às outras, formando estruturas multiméricas por meio de domínios de interação $\mathrm{N}$ - e C-terminais. Este tipo de interação entre as proteínas do nucleocapsídeo empacota o RNA e confere proteção ao ácido nucleico (Uhrig et al., 1999).

A proteína não estrutural NSs é a supressora do silênciamento viral atuando nas infecções local e sistêmica, sendo esta, uma característica genérica, de todas as proteínas NSs expressas pelos membros do gênero Tospovirus (Kormelink et al., 1991; Takeda et al., 2002; Bucher et al., 2003; Margaria et al., 2007; Hedil et al., 2015). Análises bioquímicas demonstraram que a NSs dos tospovírus tem capacidade de se associar aos micro RNAs (miRNAs), sequestrando essas moléculas e impedindo a entrada no complexo RISC da planta e por consequência inibe o sistema de defesa do 
hospedeiro. Assim, a supressão do silenciamento gênico da planta pela NSs é transcricional (Margaria et al., 2007; Schnettler et al., 2010; Hedil et al., 2015). Além disso, as NSs(s) codificadas pelos tospovírus apresentam distintos domínios de ligação a proteínas elementares ao sistema de defesa da planta, sugerindo a inviabilização da função de defesa dessas proteínas e justificando as diferentes respostas das espécies de tospovírus ao ataque anti-viral (Hedil et al., 2015).

A NSm é a proteína de movimento célula-a-célula que se associa a membranas celulares em ambas porções $\mathrm{N}$ - e C-terminal com orientação voltada para o citosol (Kormelink et al., 1994; Leastro et al., 2015). Esta característica garante a ligação da NSm com a membrana do retículo endoplasmático, possibilitando o tráfego pela meio celular e passagem para a célula adjacente, pois o retículo endoplasmático compõe uma rede de membranas espalhadas por todo o citoplasma e atravessa o plasmodesma, criando vias de mobilização de grandes moléculas (Leastro et al., 2015; Feng et al., 2016). A NSm tem capacidade de se associar a ela mesma e à proteína N (Kormelink et al., 1994; Leastro et al., 2015). A co-ligação de NSm(s) permite a formação de túbulos (40-45 nm) que auxiliam no transporte do nucleocapsídeo célula-a-célula e não da partícula completa $(80-120 \mathrm{~nm})$, pois o limite de exclusão do plasmodesma $(5 \mathrm{~nm})$ não permitiria a passagem da partícula completa $(80-120 \mathrm{~nm})$, mesmo quando admite-se extensões do limite de exclusão (por exemplo a passagem de partículas de Cowpea Mosaic virus de $28 \mathrm{~nm}$ ) (Storms et al., 1995). Contudo, isolados com mutações no RNA M que impossibilitam a formação de partículas completas, ainda são capazes de se translocar e garantir infecção sistêmica na planta hospedeira (Resende et al., 1991; Kormelink et al., 1992b). Tudo indica que a associação da NSm com a proteína N não é específica, isso possibilita a interação direta de diferentes espécies de tospovírus em uma infecção mista (Leastro et al., 2015).

As glicoproteínas (GPs) compõem o envelope da partícula e são responsáveis pela associação com o vetor. As GPs interagem com um ou mais receptores celulares no intestino do inseto (Bandla et al., 1998). A abundância desses receptores é menor nos adultos do que nas larvas, diminuindo drasticamente com seu desenvolvimento e justificando o fato de a aquisição do vírus ocorrer no estágio larval e a transmissão na fase adulta (Paliwal, 1973; Bandla et al., 1998).

\subsection{Taxonomia, filogenia e diversidade de Tospovirus}

O gênero Tospovirus pertence à família Bunyaviridae, a qual é composta por patógenos que infectam plantas, humanos e animais. Os membros da família são 
caracterizados em gênero e espécie de acordo com a combinação de algumas características, como: o tipo de hospedeiro, podendo ser vertebrado, insetos e plantas; organização genômica; interações sorológicas e moleculares da proteína $\mathrm{N}$ com outros membros da família; tipo de vetor; e identidade da sequência de aminoácidos da proteína $\mathrm{N}$ do nucleocapsídeo (King et al., 2012). Atualmente são reconhecidas pelo Comitê Internacional de Taxonomia de Vírus (ICTV) 100 espécies de vírus na família Bunyaviridae, contudo mais de 300 espécies já foram relatadas em diversas partes do mundo (Briese et al., 2013; ICTV, 2015). As espécies estão divididas em cinco gêneros: Orthobunyavirus, Hantavirus, Nairovirus, Phlebovirus e Tospovirus. Desse total de espécies, apenas uma pequena porção infecta plantas, compondo o gênero Tospovirus (de Haan et al., 1989; Francki et al., 1991; Kormelink et al., 1992b; King et al., 2012).

Os critérios taxonômicos definidos pelo ICTV determinam que indivíduos de uma mesma espécie tem que possuir mais do que $90 \%$ de identidade na sequência de aminoácidos da proteína $\mathrm{N}$ do nucleocapsídio e apresentar relação sorológica na mesma proteína, além disso, devem compartilhar o ciclo de hospedeiras e serem transmitidos pelos mesmos insetos vetores (King et al., 2012). Assim, hoje são conhecidas onze espécies definitivas de tospovírus e mais dezoito aguardam estudos complementares para serem classificadas, sendo consideradas espécies tentativas (de Ávila et al., 1992; de Ávila et al., 1993a; Satynarayana et al., 1996; Nagata et al., 1998; Qiu et al., 1998; Satynarayana et al., 1998; Bezerra et al., 1999; Kato el al., 2000; Chu et al., 2001; McMichael et al., 2002; Chen et al., 2005; Hassani-Mehraban et al., 2005; Dong et al., 2008; Ciuffo et al., 2009 Hassani et al., 2010; Li et al., 2011; Seepiban et al., 2011; Zhou et al., 2011; Oliveira et al., 2012; Torres et al., 2012; Dong et al., 2013; Meng et al., 2013; Smith et al., 2013; Cheng et al., 2014; ICTV, 2015; Margaria et al., 2014; Shimomoto et al., 2014; Yin et al., 2014) (Tabela 5).

Alguns trabalhos de comparação da diversidade de tospovirus indicam que novos parâmetros podem ser usados na taxonomia de tospovirus, incluindo a análise conjunta de outras proteínas virais. Por meio de análises filogenéticas baseadas nas sequências de aminoácidos das proteínas $\mathrm{N}$ e NSm as espécies de tospovírus foram agrupadas em dois clados, os quais foram classificados como americano e euroasiático devido à distribuição geográfica das espécies (Figura 9) (Silva et al., 2001). 

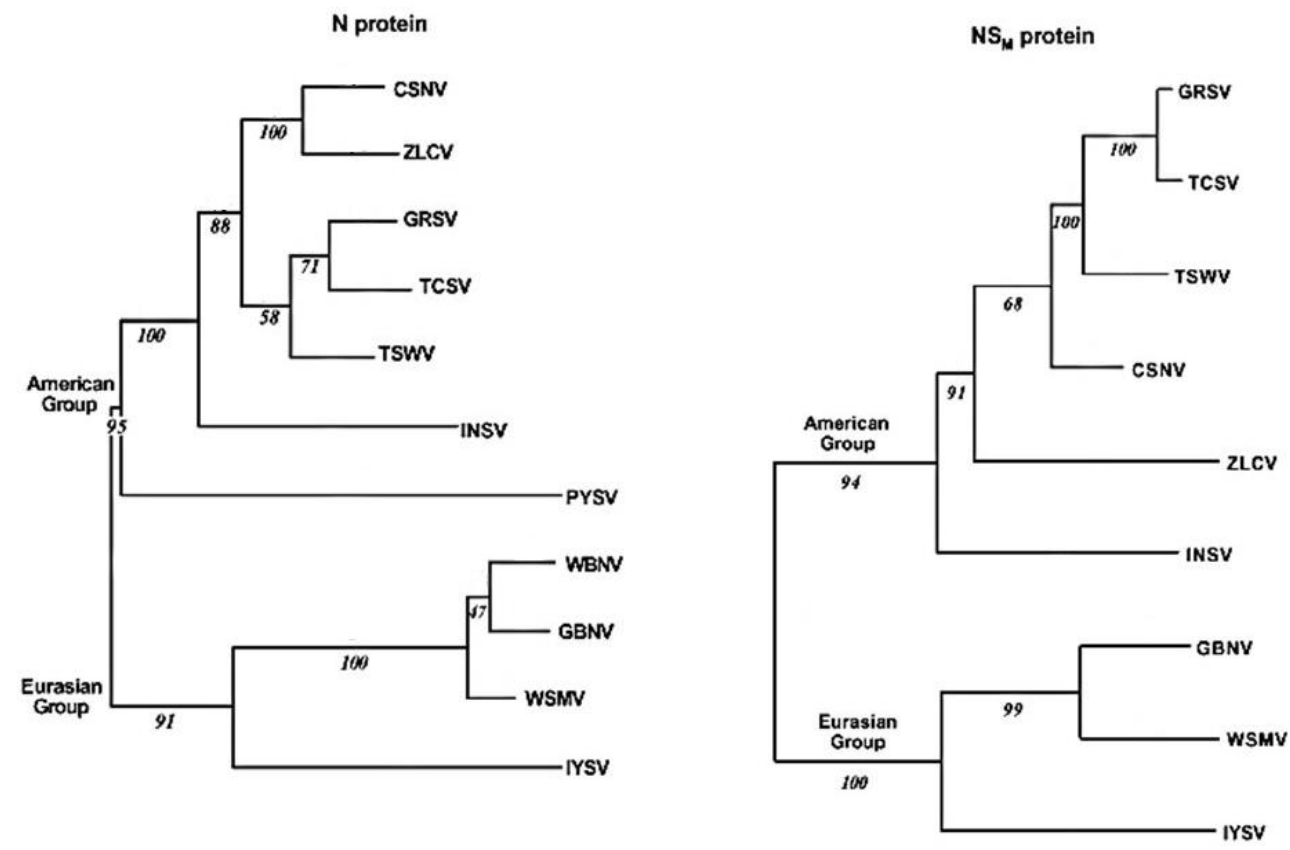

Figura 9. Filogenia de Tospovirus baseada nas sequencias de aminoácidos das proteínas N e NSm. As árvores mais parcimoniosas foram construídas com o programa PAUP 3.1 com suporte dos nós determinado por 'bootstrap' de 100 replicações. Dois grupos de tospovírus são indicados nas ávores: americano e euroasiático. TSWV (Tomato spotted wilt virus), WSMV (Watermelon silver mottle virus), GBNV (Groundnut bud necrosis virus), INSV (Impatiens necrotic spot virus), GRSV (Groundnut ringspotring spot virus), TCSV (Tomato chlorotic spot virus), CSNV (Chrysanthemum stem necrosis virus), ZLCV (Zucchini lethal chlorosis virus), IYSV (Iris yellow spot virus), WBNV (Watermelon bud necrosis virus), PYSV (Peanut yellow spot virus). Fonte: Silva et al., 2001. 
Tabela 5. Relação das espécies de tospovírus definitivas (itálico) e tentativas

\begin{tabular}{|c|c|c|c|}
\hline Acrônimo & Nome do vírus & País & $\mathrm{N}^{\circ}$ acesso Genebank ${ }^{\circledR}$ \\
\hline ANSV & Alstromeria necrotic streak virus & Colômbia & GQ478668.1 \\
\hline BeNMV & Bean necrotic mosaic virus & Brasil & JN587268.1 \\
\hline $\mathrm{CaCV}$ & Capsicum chlorosis virus & Austrália & NC_008301.1 \\
\hline CCSV & Calla lily chlorotic spot virus & Taiwan & AY867502.1 \\
\hline CSNV & Chrysanthemum stem necrosis virus & Brasil & KM114548 \\
\hline GBNV & Groundnut bud necrosis virus & Índia & AY871098.2 \\
\hline GRSV & Groundnut ringspot virus & Brasil & AF487516.1 \\
\hline GYSV & Groundnut yellow spot virus & Índia & AF013994.1 \\
\hline HCRV & Hippeastrum chlorotic ringspot virus & China & JX833564 \\
\hline INSV & Impatiens necrotic spot virus & EUA & X66972.1 \\
\hline IYSV & Iris yellow spot virus & EUA & AF001387.1 \\
\hline LNRV & Lisianthus necrotic ringspot virus & Japão & AB852525 \\
\hline MSMV & Melon severe mosaic virus & Mexico & EU275149.1 \\
\hline MVBaV & Mulberry vein banding associated virus & China & KM819701.1 \\
\hline MYSV & Melon yellow spot virus & Japão & АВ038343.1 \\
\hline PCFSV & Peanut chlorotic fan- spot virus & Taiwan & AF080526.1 \\
\hline PCSV & Pepper chlorotic spot virus & Taiwan & KF383956 \\
\hline PNSV & Pepper necrotic spot virus & Peru & HE584762.1 \\
\hline PolRSV & Polygonum ringspot virus & Italy & KJ541744 \\
\hline SVNaV & Soybean vein necrosis associated virus & EUA & HQ728387.1 \\
\hline TCSV & Tomato chlorotic spot virus & Brasil & AF282982.1 \\
\hline TNRV & Tomato necrotic ringspot virus & Thailand & FJ489600.2 \\
\hline TNSaV & Tomato necrotic spot-associated virus & China & KM355773.1 \\
\hline TSWV & Tomato spotted wilt virus & Austrália & AF020660.1 \\
\hline TYRV & Tomato yellow ring virus & Irã & AY686718.1 \\
\hline TZSV & Tomato zonate spot virus & China & EF552433.1 \\
\hline WBNV & Watermelon bud necrosis virus & Índia & GU584184.1 \\
\hline WSMoV & Watermelon silver mottle virus & Taiwan & AB042650.1 \\
\hline ZLCV & Zucchini lethal chlorosis virus & Brasil & AF067069.1 \\
\hline
\end{tabular}

Fonte: de Ávila et al., 1992; de Ávila et al., 1993a; Satynarayana et al., 1996; Nagata et al., 1998; Qiu et al., 1998; Satynarayana et al., 1998; Bezerra et al., 1999; Kato el al., 2000; Chu et al., 2001; McMichael et al., 2002; Chen et al., 2005; Hassani-Mehraban et al., 2005; Dong et al., 2008; Ciuffo et al., 2009 Hassani et al., 2010; Li et al., 2011; Seepiban et al., 2011; Zhou et al., 2011; Oliveira et al., 2012; Torres et al., 2012; Dong et al., 2013; Meng et al., 2013; Smith et al., 2013; Cheng et al., 2014; ICTV, 2015; Margaria et al., 2014; Shimomoto et al., 2014; Yin et al., 2014; Zheng et al., 2016. 
Novas tecnologias como o Sequenciamento de Nova Geração, ou 'New Generation Sequencing' (NGS), tem permitido a descoberta de novas espécies de tospovírus, bem como, o monitoramento de diferentes espécies de tospovírus em várias regiões geográficas do mundo.

A caracterização recente de duas novas espécies no continente americano Bean necrotic mosaic virus (BeNMV) e Soybean vein necrosis associated virus ( $\mathrm{SVNaV}$ ), introduziu um novo clado na filogenia do gênero Tospovirus quase equidistante dos grupos americano e euriasiático, sugerindo que esse novo clado representa uma nova linhagem no gênero Tospovirus (Oliveira et al., 2012; Zhou et al., 2011) (Figura 10). Algumas dessas espécies vêm sendo alvo de estudos mais aprofundados sobre suas características moleculares e epidemiologias (Leastro et al., 2015, Zhou and Tzanetakis, 2013, Groves et al., 2016).

Baseado em análises filogenéticas, o gênero Tospovirus é comumente separado em dois clados: americano e euroasiático, representando dois centros de diversificação de espécies a partir de um ancestral comum. No clado americano estão espécies que são mais similares a TSWV, enquanto espécies mais próximas a Watermelon silver mottle virus estão no clado euroasiático. No entanto, Iris yellow spot virus (IYSV) representa um caso curioso: como doença "tipo-tospovírus" foi descrita pela primeira vez no início da década de 1980 em cebolas no Brasil, mas de acordo com sua filogenia é uma espécie classificada no clado euroasiático, próxima a espécies como Polygonum ringspot virus (PolRSV), Tomato yellow ring virus (TYRV) e Hippeastrum chlorotic ringspot virus (HCRV) (Figura 10) (de Ávila et al, 1981; Bag et al., 2015). Não obstante, IYSV caracterizado como nova espécie por Cortês e colaboradores na Holanda em 1998, possui grande relevância nos Estados Unidos da América, onde causa danos severos de rendimento a plantações de cebola (Nischwitz et al., 2007). Iris yellow spot virus (IYSV) também foi encontrado em Israel, Irã e Holanda, indicando que a divisão filogenética de cunho geográfico pode não ser bem correlacionada à história do vírus. $\mathrm{O}$ exemplo da espécie IYSV demonstra claramente a introdução de vírus pertencentes a um clado em outra região geográfica, provavelmente devido ao fluxo de material vegetal contaminado. 


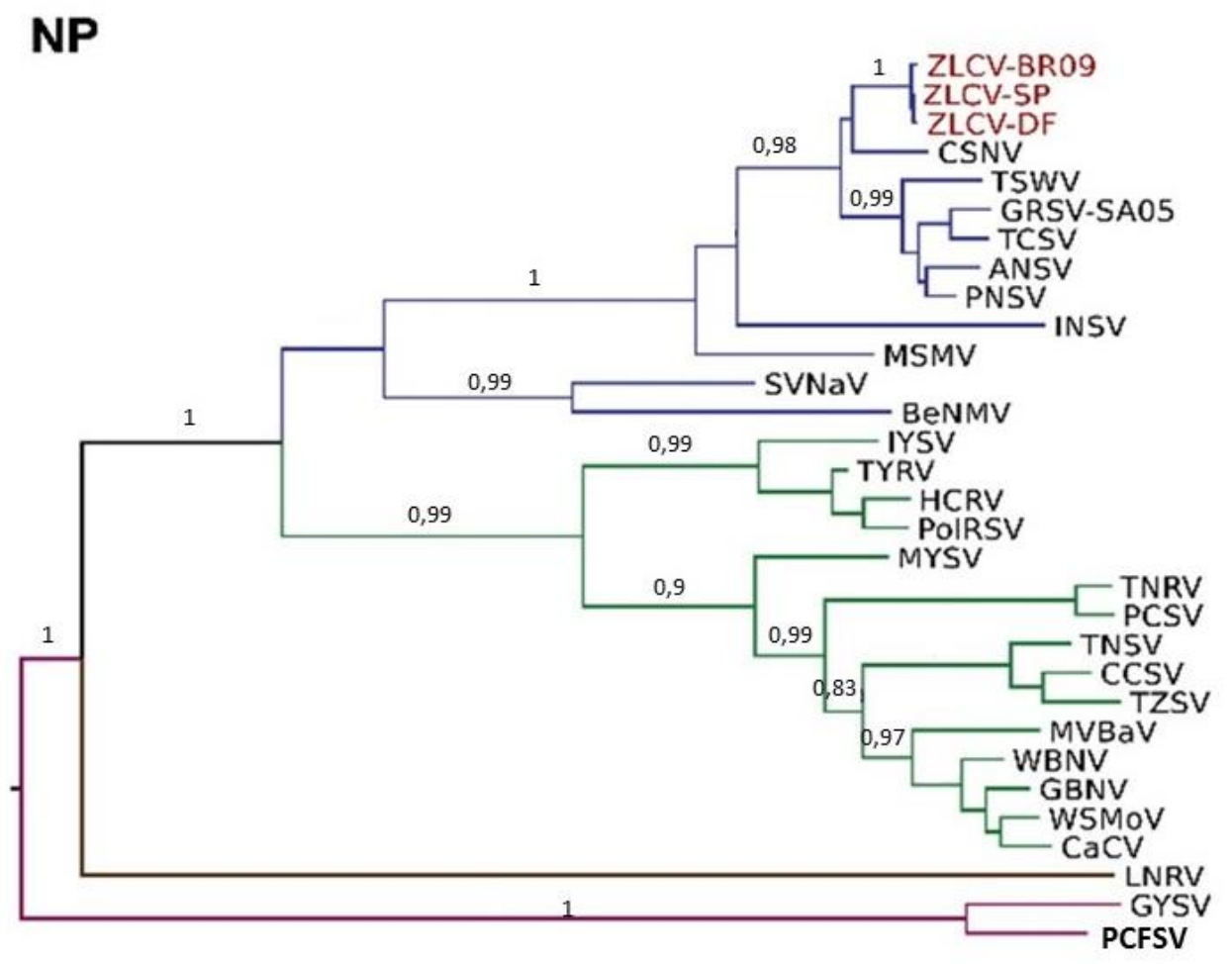

Figura 10. Filogenia de Tospovirus baseada nas sequências de aminoácidos da proteína do nucleocapsídeo (NP). As árvores mais parcimoniosas foram construídas com o programa Geneious. Os valores de probabilidade posterior e suporte dos ramos estão sinalizados nos braços da árvore. Os ramos em azul sinalizam o grupo americano composto por ZLCV (Zucchini lethal chlorosis virus), CSNV (Chrysanthemum stem necrosis virus), TSWV (Tomato spotted wilt virus), GRSV (Groundnut ringspotring spot virus), TCSV (Tomato chlorotic spot virus), ANSV (Alstromeria necrotic streak virus), PNSV (Pepper necrotic spot virus), INSV (Impatiens necrotic spot virus), MSMV (Melon severe mosaic virus), SVNaV (Soybean vein necrotic associated virus) e BeNMV (Bean necrotic mosaic virus). Os ramos em verde representam o grupo euroasiático composto por IYSV (Iris yellow spot virus), TYRV (Tomato yellow ring virus), HCRV (Hippeastrum chlorotic ringspot virus), PolRV (Polygonum ringspot virus), WSMoV (Watermelon silver mottle virus), MYSV (Melon yellow spot virus), TNRV (Tomato necrotic ringspot virus), PCSV (Pepper chlorotic spot virus), TNSV (Tomato necrotic spot virus), CCSV (Calla lily chlorotic spot virus), TZSV (Tomato zonate spot virus), MVBaV (Mulberry vein banding associated virus), WBNV (Watermelon bud necrosis virus), GBNV (Groundnut bud necrosis virus) e $\mathrm{CaCV}$ (Capsicum chlorosis virus). O ramo marrom representa o clado de LNRV (Lisianthus necrotic ringspot virus), composto por apenas esta espécie. O ramo roxo compõe o clado de GYSV (Groundnut yellow spot virus) e PCFSV (Peanut chlorotic fan-spot virus). Fonte: Lima et al., 2016.

\subsection{Vetores de tospovirus}

Com exceção das hantaviroses, para as quais não se sabe se possuem insetos como vetor, todos os outros vírus da família Bunyaviridae são transmitidos por uma ou várias espécies de artrópode (King et al., 2012). Os tospovírus são transmitidos por diversas espécies de tripes (ordem Thysanoptera) de maneira circulativa-propagativa, adquirindo o vírus no estádio larval e o transmitindo com mais eficiência no estádio adulto (Ullman et al., 1993; Wijkamp et al., 1995; Wetering et al., 1996).

Atualmente são conhecidas mais de 2000 espécies de tripes, contudo apenas 14 foram relatadas como transmissoras de tospovírus (Pappu et al., 2009; Rlley et al., 2011; 
Wang et al., 2016). No Brasil, cerca de 520 espécies de tripes ordenadas em 139 gêneros e seis famílias foram relatadas, sendo que apenas 5 são transmissoras de tospovírus: Frankliniella occidentalis, F. schultzei, F. zucchini, Thrips tabaci e T. palmi (Nagata et al., 1999; Monteiro, 2001; Nagata et al., 2000; Nagata et al., 2004) (Tabela $6)$.

Tabela 6. Espécies de tripes vetoras de tospovírus

\begin{tabular}{|c|c|}
\hline Tripes & Tospovírus transmitido \\
\hline Frankliniella occidentalis & $\begin{array}{l}\text { Chrysanthemum stem necrosis virus } \\
\text { Groundnut ringspot virus } \\
\text { Impatiens necrotic spot virus } \\
\text { Tomato chlorotic spot virus } \\
\text { Tomato spotted wilt vírus }\end{array}$ \\
\hline Thrips tabaci & $\begin{array}{l}\text { Iris yellow spot virus } \\
\text { Tomato spotted wilt virus } \\
\text { Tomato yellow ring virus }\end{array}$ \\
\hline Frankliniella schultzei & $\begin{array}{l}\text { Chrysanthemum stem necrosis } \\
\text { Groundnut ringspot virus } \\
\text { Groundnut bud necrosis virus } \\
\text { Tomato chlorotic spot virus } \\
\text { Tomato spotted wilt virus }\end{array}$ \\
\hline Frankliniella fusca & $\begin{array}{l}\text { Tomato spotted wilt virus } \\
\text { Impatiens necrotic spot virus }\end{array}$ \\
\hline Thrips palmi & $\begin{array}{l}\text { Calla lily chlorotic spot virus } \\
\text { Groundnut bud necrosis virus } \\
\text { Melon yellow spot virus } \\
\text { Watermelon silver mottle virus }\end{array}$ \\
\hline Scirtothrips dorsalis & $\begin{array}{l}\text { Groundnut bud necrosis virus } \\
\text { Peanut chlorotic fan-spot virus } \\
\text { Groundnut yellow spot vírus }\end{array}$ \\
\hline Frankliniella intonsa & $\begin{array}{l}\text { Groundnut ringspot virus } \\
\text { Impatiens necrotic spot virus } \\
\text { Tomato chlorotic spot virus } \\
\text { Tomato spotted wilt virus }\end{array}$ \\
\hline Frankliniella bispinosa & Tomato spotted wilt virus \\
\hline Thrips setosus & Tomato spotted wilt virus \\
\hline Ceratothripoides claratris & Capsicum chlorosis virus \\
\hline Frankliniella zucchini & Zucchini lethal chlorosis virus \\
\hline Frankliniella gemina & $\begin{array}{l}\text { Tomato spotted wilt virus } \\
\text { Groundnut ringspot virus }\end{array}$ \\
\hline Frankliniella cephalica & Tomato spotted wilt virus \\
\hline Dictyothrips betae & Polygonum ringspot virus \\
\hline
\end{tabular}

Fonte: Wijkamp et al., 1995; Cortês et al., 1998; Kato et al., 2000; Nagata et al., 2000; Nagata et al., 2004; Chen et al., 2005; Whitfield et al., 2005; Ciuffo et al., 2009; Pappu et al 2009; Rlley et al., 2011. 
O ciclo de vida dos tripes é constituído por seis fases, sendo que as características (temperatura, umidade, tempo de incubação) no desenvolvimeto de cada fase variam com a espécie de tripes. Fêmeas adultas depositam os ovos nas superfícies das folhas ou em partes florais que depois eclodem, dando origem ao primeiro estágio larval, ou primeiro instar, que se desenvolve para o segundo estágio larval, segundo instar. Ambos os estágios larvais não possuem asas e se alimentam nas folhas ou nas flores da planta hospedeira. Em seguida, há dois estágios pulpais que não se alimentam e seu desenvolvimento pode ser na planta ou no solo, dependendo da espécie de tripes. Adultos alados são formados após os estágios de pulpa e se dispersam rapidamente (Whitfiel et al., 2005) (Figura 11).

Os tripes perfuram a epiderme da planta e sugam o conteúdo celular do mesófilo, destruindo muitas células e causando danos ao tecido (Ullman et al., 1992). Após a ingestão das partículas virais, os vírions se dispersam da parte superior do intestino até a porção média, o primeiro local de entrada do vírus nas células do inseto. As microvilosidades da borda em escova do intestino médio são as primeiras barreiras encontradas pelos vírus. Os vírus atravessam o epitélio do intestino médio, passam por camadas de células musculares, migram até as glândulas salivares onde atravessam a camada epitelial que reverte o órgão, atingem o lúmem para serem excretados juntamente com a saliva no momento da alimentação (Nagata et al., 1999).

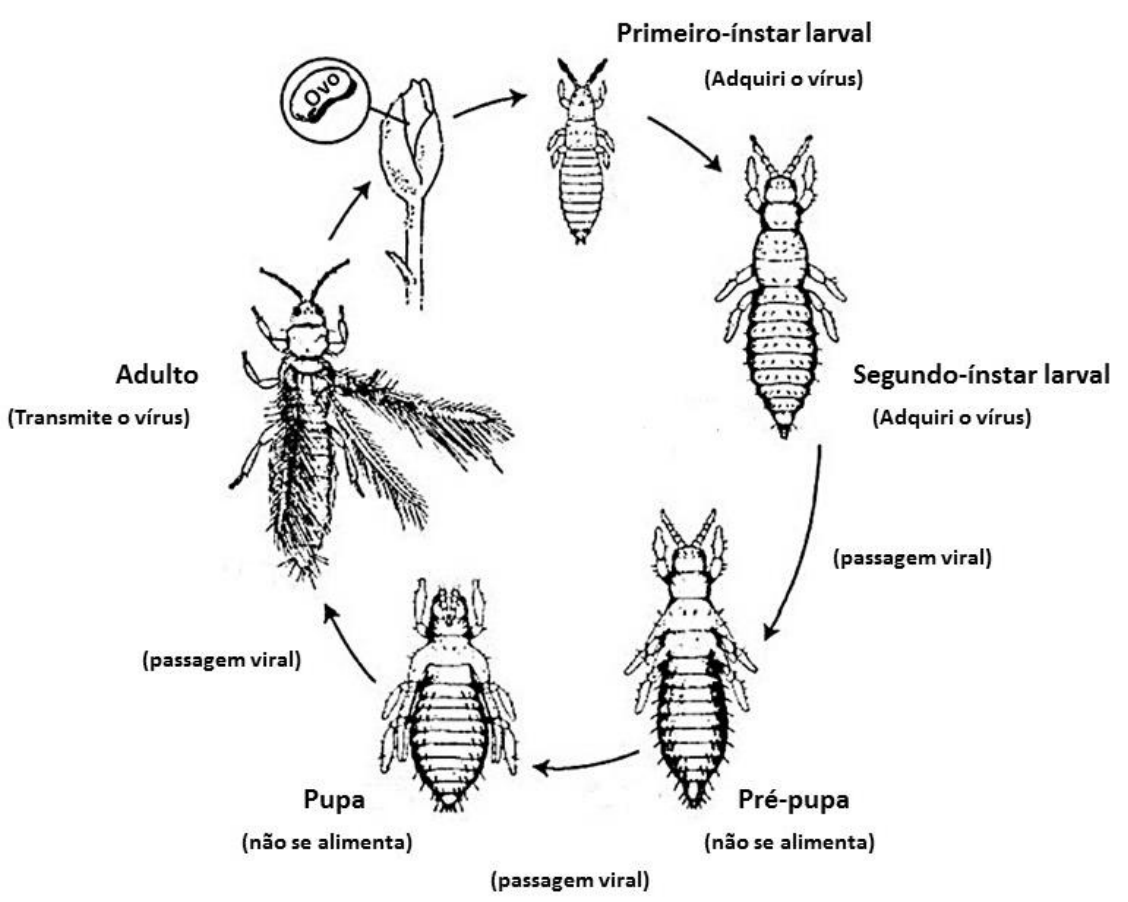

Figura 11. Ciclo de vida do tripes e o ciclo de transmissão de tospovírus. Fonte: Kuepper, 2004. 


\subsection{Aspectos econômicos e epidemiológicos}

Os tospovírus estão entre os principais agentes causadores de problemas fitossanitários no campo (Pappu et al., 2009). TSWV foi colocado na lista dos 10 vírus vegetais que mais causam danos em culturas, sendo responsável pela perda de bilhões de dólares (Scholthof et al., 2011). TSWV infecta mais de 1000 espécies de plantas, entre monocotiledôneas (15 famílias), dicotiledôneas (69 famílias) e uma família de pteridófitas (Parrella et al., 2003). Doenças causadas por tospovírus foram reportadas em todos os continentes, afetando culturas de batata, alface, cebola, alho, feijão, pimentas e pimentões, soja, ervilha, cucurbitáceas, tomate, amora e muitas ornamentais (Pappu et al., 2009). Já foram estimadas perdas anuais de mais de \$1 bilhão, ocasionadas, apenas, por TSWV (Prins et al., 1998). Entre os anos de 1996 e 2006 as perdas geradas por infecções de TSWV só no estado da Georgia nos Estados Unidos foram em média de \$326 milhões, atingindo as culturas de amendoim (\$12.3 milhões), tabaco (\$11.3 milhões), tomate e de pimenteiras (\$9 milhões). Extrapolando esses dados para todo o país, podem-se considerar perdas de $\$ 1.4$ bilhões nessas culturas apenas nos Estados Unidos (Rlley et al., 2011).

No Brasil, foram relatadas as espécies BeNMV, GRSV, CSNV, TCSV, TSWV, IYSV e ZLCV (Costa et al., 1941; de Ávila et al., 1993a; de Ávila et al., 1996; Nagata et al., 1998; Bezerra et al., 1999; Pozzer et al., 1999; Oliveira et al., 2012). Contudo, as principais espécies encontradas no campo são GRSV e TSWV prevalentes em plantios de tomateiro e pimenteiras, levando a perdas econômicas significativas quando epidêmicas (Boiteux et al., 1993; Resende et al.,1996; Lima et al., 2000).

Existem relatos de TSWV no Brasil há várias décadas no estado de Pernambuco, causando prejuízos na cultura de alface, pimentão e tomateiro. Os primeiros surtos de TSWV no Submédio do Vale do São Francisco ocorreram em 1995 nas culturas de pimentão e tomateiro quando foi estimada perda de $30 \%$ da produção em tomateiro (de Ávila et al., 1996). No último levantamento da ocorrência de tospovírus em tomate e pimentão no Brasil ocorrido no período de 1995 a 1997 foi constatado que a espécie predominante era GRSV, quando esta foi detectada em 76,2\% das 202 amostras de pimentão analisadas no período e em 67,0\% das 630 amostras de tomate (Lima et al., 2000). As perdas geradas por tospovírus no Brasil são significativamente relevantes, principalmente tratando-se de hortaliças. Atualmente, GRSV é a espécie 
economicamente mais importante para o país, gerando prejuízos no cultivo de culturas essenciais para a produção agrícola nacional, como tomate e pimentão.

TCSV e GRSV classificados no sorogrupo II, porém em sorotipos diferentes, apresentam relação filogenética muito próxima $(81 \%$ identidade sequência de aminoácidos da proteína $\mathrm{N}$ ) e ambos foram descritos infectando tomateiro no Brasil no início da década de 90 com os isolados B3 (TCSV) e B6 (GRSV) (de Ávila et al., 1990; de Ávila et al., 1993a) (Tabela 1). Inicialmente, TCSV e GRSV mantiveram nicho restrito a poucos estados brasileiros. Contudo, GRSV venceu as barreiras de nicho e se alastrou por diversos outros estados, tornando-se a espécie de tospovírus mais relevante no Brasil na atualidade, enquanto que TCSV permanece restrito a alguns estados brasileiros (Nagata et al., 1995; de Ávila et al., 1996; Lima et al., 2000; Eiras et al., 2012). No entanto, nos últimos 4 anos, novos relatos de infecções severas causadas por TCSV têm ocorrido em países do Caribe (República Dominicana e Costa Rica) e em estados do sul e sudeste dos Estados Unidos, onde GRSV também é relatado. (Webster et al., 2010; Londoño et al., 2012; Webster et al., 2013; Batuman et al., 2015; Webster et al., 2015). Além das espécies tipos, indentificadas na América do Norte, foram relatados os primeiros isolados híbridos (proposto como rearranjo viral) entre espécies de tospovírus, os quais possuem os segmentos $\mathrm{S}$ e L de GRSV e $\mathrm{M}$ de TCSV (denominados $\mathrm{S}_{\mathrm{GRSV}} \mathrm{M}_{\mathrm{TCSV}} \mathrm{L}_{\mathrm{GRSV}}$ ), sendo a proximidade genética dessas duas espécies o principal fator para viabilizar a troca dos componentes (Webster et al., 2011).

IYSV infecta preferencialmente plantas do gênero Allium spp. Dentre todas as espécies de tospovírus conhecidas atualmente, é o único membro do grupo asiático relatado nos cinco continentes (Cortês et al., 1998; Pozzer et al., 1999; Ravi et al., 2006; Nischwitz et al., 2007; Krauthausen et al., 2012; 2015; Fuji et al., 2015) (Figura 10). O sucesso de dispersão dessa espécie é relacionado à presença do tripes Thrips tabaci, o qual é constantemente encontrado nos bulbos e nas proximidades de campos infectados e apresenta uma alta eficiência na transmissão dispersão de IYSV. Além disso, como a principal forma de propagação de Allium spp. é vegetativa, o comércio de produtos agrícolas deve ter contribuído significativamente para a disseminação do vírus (Nischwitz et al., 2007; Krauthausen et al., 2012; 2015; Fuji et al., 2015). 


\subsection{Tospovírus na República Dominicana}

$\mathrm{Na}$ República Dominicana o cultivo de solanáceas como o tomateiro e pimenteiras tem grande relevância econômica, pois seus produtos são destinados ao mercado externo, sendo exportados para os Estados Unidos, Canadá e Europa. Atualmente, essa importante atividade econômica está ameaçada, devido à crescente presença dos tospovírus nos campos cultivados, principalmente o vírus denominado como o bronzeado do tomateiro (TSWV) (Martínez et al., 2014).

Durante a safra de 2009, muitos produtores das regiões Constanza e Jarabocoa (importantes áreas produtoras de hortaliças no pais) eliminaram seus cultivos devido à alta incidência de viroses, identificando-se o TSWV, como principal agente causal das enfermidades (Martínez et al., 2014). Durante o período de setembro a junho de 2013, os plantios em cultivo protegido também nas regiões de Constanza e Jarabacoa foram eliminadas devido à alta incidência de plantas com sintomas de TSWV, atingindo até 100\% (Comunicação pessoal R.T. Martínez). O TSWV é conhecido por possuir uma vasta gama de hospedeiros, principalmente nas famílias Solanaceae e Fabaceae, com um incontável número de espécies cultivadas e não cultivadas suscetíveis à esta espécie viral. Na região de Constanza, a incidência de TSWV no cultivo de batata (Solanum tuberosum) foi de até $60 \%$, assim como nos cultivos de feijão-vagem (Vigna unguiculata) e pimenta picante (Capsicum frutenscens) na localidade de Moca (Martínez, comunicação pessoal). Além de causar perdas em pimentas e tomate de cultivo protegido, TSWV foi detectado em tomate indústria no Noroeste do país com alta incidência e severidade de sintomas (R. Gilbertson, comunicação pessoal). Não há dúvidas que o vírus está se expandindo de cultivos protegidos para campos abertos. $\mathrm{O}$ TSWV é transmitido principalmente pelos tripes Frankliniella occidentalis e Thrips tabaci, os quais foram encontrados em várias regiões do país (Valdez et al., 2016). O vírus e seus vetores têm uma ampla gama de hospedeiras cultivadas e hospedeiras alternativas (ervas-daninhas), dificultando o manejo da doença.

A luta contra as doenças virais é muito complexa, pois os sintomas ocasionados podem ser alterados por diversos quesitos tais como a idade da planta hospedeira, fatores nutricionais, diferenças entre as estirpes de vírus que infectam a planta (Fernandes-Carrijo et al., 2006, Pereira-Carvalho et al., 2015a). Devido ao desconhecimento dos sintomas, os vírus podem ser disseminados pelos produtores mediante a utilização de material vegetal contaminado, como mudas e tubérculossementes (Pereira-Carvalho et al., 2015b). A identificação de maneira precisa e 
confiável garante a detecção de focos recentes, prevenindo futuras epidemias ao utilizar material suscetível (Dianese et al., 2015).

O manejo dos vírus deve ser de forma preventiva, diferentemente dos fungos e bacterias, para os quais, utilizam-se métodos curativos. Os vírus não respondem a tratamentos químicos uma vez que infectam seus hospedeiros. O controle viral mediante o uso de materiais resistentes ou tolerantes é a melhor alternativa (Bedendo, 1995). A situação apresentada por TSWV, que têm sido detectada em diversos cultivos e em diferentes regiões produtoras no país, incluindo também as localidade de San José de Ocoa e Azua, pode ser o indício de uma epidemia por tospovírus, como a que ocorreu com o vírus do enrolamento amarelo das folhas de tomateiro, causado pelo begomovírus Tomato yellow leaf curl virus (TYLCV) em 1994 (Nakhla et al., 1994). Apesar da alta incidência, severidade e do abandono de várias culturas devido à infecção viral, não existem informações dos níveis de danos causados em pimenteira e tomateiro. Na maioria dos casos os produtores não dispõem de materiais resistentes ou tolerantes aos vírus.

A República Dominicana representa um nicho ecológico com introduções recentes de espécies de tospovírus. Em 2012 infecções por tospovírus se alastraram por diversos cultivos causando grandes danos, quadro que se estende até a atualidade. Nesta situação, foi possível detectar as espécies TSWV e TCSV, infectando tomateiro (TCSV e TSW), batateira (TSWV), pimenteiras (TCSV e TSWV), pimentão (TSWV), feijoeiro (TCSV), fumo (TCSV) e ervas-daninhas ao redor dos cultivos, sendo os primeiros relatos de TCSV no país, no feijoeiro e em fumo (Batuman et al., 2015; dados coletados neste trabalho de tese). Acompanhar o comportamento de novas espécies introduzidas na ilha é muito valioso, para que possamos complementar estudos de evolução e adaptação a novos nichos pelos tospovírus, comparando à regiões geográficas onde a interação entre diferentes espécies parece ter atingido um patamar mais estável. Assim, este quadro epidemiológico de espécies de tospovirus, presente na República Dominicana, pode se tornar um bom modelo para o estudo de hipóteses de especiação no gênero, em contraste com regiões de maior equilíbrio populacional, como o Brasil.

\subsection{Rearranjo no gênero Tospovirus}

Vírus compostos por genoma segmentado podem sofrer frequentes recombinações e/ou rearranjos de seus componentes, sendo, essas, uma das justificativas evolutivas para o sucesso de tais organismos (Webster et al., 2011). Estas trocas genéticas são as razões fundamentais para a existência de genomas virais 
segmentados, elas permitem novas combinações no genoma a partir de distintas modificações e eliminam características indesejáveis à carga genética. Na recombinação, há a formação de quimeras dos ácidos nucleicos, resultando em uma nova molécula com fragmentos do(s) genoma(s) parental(is). O rearranjo é caracterizado pela troca de componentes inteiros do genoma segmentado em uma mesma partícula viral, preservando-se a sequência nucleotídica original (Tentchev et al., 2011) (Figura 12). Esses dois mecanismos podem ser a chave para evolução e adaptação das espécies a novas hospedeiras e colonização de novos nichos, aumentando o espectro de ação do vírus e burlando possíveis sistemas de defesa das plantas, como genes de resistências.

Análises recentes de 57 isolados TSWV revelaram que a ocorrência de recombinação é maior no RNA L, seguida pelo RNA M e por último o RNA $S$ é o segmento que menos sofre recombinação. Seis eventos de recombinação foram observados no RNA L de dezessete isolados de TSWV, quatro eventos no RNA M de quarenta e sete isolados e apenas dois eventos no RNA $S$ de seis isolados de TSWV. Neste caso, a deriva genética foi o principal fator relacionado às diferenças filogenéticas observadas nesses isolados (Lian et al., 2013).

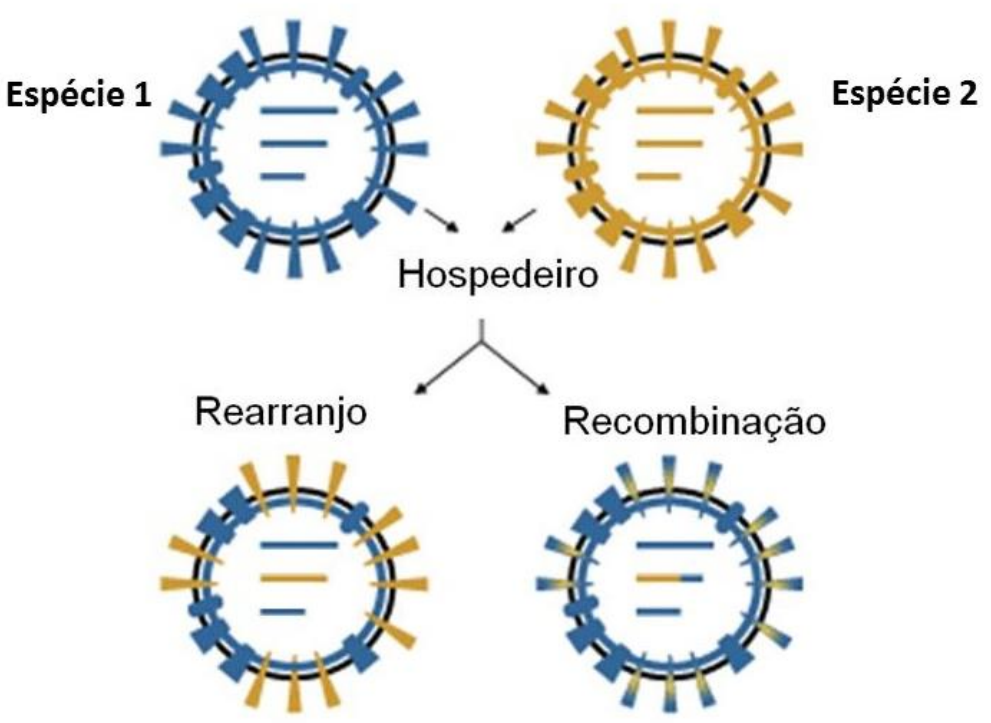

Figura 12. Esquema representativo de rearranjo e recombinação entre vírus com genoma segementado, como os tospovírus. O rearranjo é caracterizado por troca de segmentos inteiros do genoma, enquanto, na recombinação, apenas partes do genoma são trocadas entre os diversos segmentos do genoma virais.

Apesar do rearranjo ocorrer em baixas taxas entre os membros da família Bunyaviridade, uma grande quantidade de isolados rearranjados de TSWV foi 
recentemente relatada em amostras da Espanha, Itália e França e, um novo isolado, carregando os segmentos L e S de GRSV e o segmento M de TCSV, foi encontrado infectando plantas de tomate na Flórida, Estados Unidos. Mesmo tendo havido recentes relatos de rearranjos intra e inter-espécies de tospovírus, este fenômeno parece não ser comum entre espécies de tospovirus. Um grande número de isolados de TSWV que não sofreram rearranjo foi encontrado em pequenas áreas separadas por $35 \mathrm{~km}$, ou menos, demonstrando que há uma importante pressão seletiva ocorrendo nessas interações (Tenchev et al., 2011). Desta forma, apesar de a ocorrência ser baixa, o rearranjo pode ser uma importante ferramenta adaptativa dos tospovírus, aumentando a dispersão das espécies (Tentchev et al., 2011; Webster et al., 2011).

O rearranjo de segmentos genômicos inter e intra-espécies de tospovírus, pode também ser uma ferramenta no estudo das funções dos genes virais, considerando-se que as espécies do gênero Tospovirus são vírus de RNA negativo e não há, até o presente, ferramentas disponíveis para a realização de genética reversa (Hoffman et al., 2001; Margaria et al, 2007). De acordo com Webster e colaboradores (2011), estudos de rearranjo com bunyavírus provaram ser úteis, pois eles têm permitido o mapeamento de atributos e funções específicas para os segmentos genômicos de RNA. Como o que foi relatado por Okuda e colaboradores (2003), quando plantas co-infectadas com estirpes de Watermelon silver mottle virus apresentaram um grande número de isolados rearranjados, facilitando a identificação de regiões com funções específicas, como as que são responsáveis pela determinação dos sintomas.

Nas condições brasileiras onde várias espécies de tospovírus já convivem por décadas, até o presente não foram detectados exemplos de rearranjos intra e interespecíficos no campo. O que pode justificar tal fato é a principal forma de detecção utilizada atualmente, a qual é baseada apenas na comparação das sequências do gene $\mathrm{N}$ do segmento $\mathrm{S}$, ou que, em áreas onde os tospovirus já estão adaptados e estabilizados, a ocorrência desses eventos é limitada. Por isso, é interessante contrastar essa situação com outros nichos ecológicos, onde as introduções de espécies de tospovirus são recentes, como por exemplo, na República Dominicana, onde as introduções de tospovirus parecem ter ocorrido há apenas 5 anos. Essas comparações entre sistemas epidemiológicos significamente distintos, podem auxiliar na elucidação da dinâmica populacional e evolução de espécies e isolados de tospovírus. 


\subsection{Estratégias de controle de tospovirus}

Os métodos de controle mais adequados para tospovírus são por meio de genes de resistência, pois as alternativas para controle do vetor não são eficientes, principalmente, devido à rápida capacidade de dispersão dos tripes, a capacidade de adquirir resistência aos produtos usados em controles químicos, a eficiência com que transmitem as espécies de tospovírus e devido à completa adaptação vírus-vetor (Cho et al., 1989; Boiteux et al., 1993a; Boiteux et al., 1993b; Wijkamp et al., 1995; Prins et al., 1998; Westmore et al., 2013).

O gene $T s w$ confere resistência em linhagens de Capsicum chinense a TSWV (Boiteux et al., 1994; Boiteux, 1995). O 'cluster' do gene $S w-5$ formado por cinco paralogos $(S w-5 a$ a $S w-5 e)$ foi detectado primeiramente em tomate selvagem (Solanum peruvianum) e em seguida em tomate comercial ( $S$. lycopersicum) e se tornou o principal alvo dos programas de melhoramento clássico e na produção de plantas transgênicas. Este gene confere resistência ampla à diversas espécies de tospovirus como o TSWV, CSNV, GRSV, INSV e TCSV (Stevens et al., 1992; Boiteux et al., 1993a; Spassova et al., 2001; Dianese et al., 2011; Oliveira, 2015; Oliveira et al., 2016). Apesar dos relatos de quebra de resistência pelos tospovírus, a utilização de resistência genética ainda é a melhor opção na tentativa de conter as infecções virais e produzir culturas com menos controle químico, preservando o meio-ambiente. Além disso, há indícios de que $S$. peruvianum possui outros genes candidatos à resistência a TSWV (Gordillo et al., 2008). A grande diversidade de espécies de tospovírus, o aparecimento de isolados capazes de quebrar a resistência dos genes de resistência conhecidos e mais recentemente, a ocorrência de rearranjos intra e interespecíficos de tospovirus, constituem um desafio para o controle desses patógenos vía resistência genética.

Os genes de avilulência $(A v r)$ de tospovírus que direcionam para quebra de resistência de genes $\mathrm{R}$ da planta conhecidos atualmente são os genes da N, NSs e da NSm (Margaria et al., 2007; Lovato et al., 2008; Oliveira et al., 2016)

\section{Problemática abordada na tese}

O Brasil está entre os países com maior número de espécies de tospovírus relatadas, juntamente com alguns países da Ásia, e possui como principal atividade na balança comercial nacional e internacional a produção agrícola. $\mathrm{O}$ combate a patógenos de plantas cultivadas torna-se imprescindível para a produção de culturas importantes para consumo interno e/ou exportação, como as hortaliças tomate e pimentão. Na tentativa de criar estratégias de defesa contra os problemas fitossanitários, é 
indispensável o conhecimento do agente causal da doença e sua variabilidade, como também gerar, para cada patógeno, ferramentas eficientes para elucidar as características biológicas e a interação que esses exercem no ambiente em que estão inseridos.

Conforme estudos recentes, a evolução de tospovírus parece ser baseada principalmente na ocorrência de rearranjos virais intra e inter-específicos para adaptação a diferentes condições biológicas (Margaria et al, 2007; Tentchev et al., 2011; Webster et al., 2011; Margaria et al., 2015) (Figura 11). Portanto, os estudos desses eventos biológicos no gênero Tospovirus, são essenciais para o entendimento do processo evolutivo e adaptativo das espécies, já que podem ocorrer naturalmente no ambiente.

Groundnut ringspot virus (GRSV), Tomato spotted wilt virus (TSWV), Tomato chlorotic spot virus (TCSV) têm sido as espécies mais relevantes no Brasil e possuem ciclo de hospedeiras semelhantes (Nagata et al., 1995; de Ávila et al., 1996; Pozzer et al., 1996; Lima et al., 2000; Eiras et al., 2012). Dessa forma, foi investigado a ocorrência natural de rearranjo em isolados brasileiros de TSWV, GRSV e TCSV. Consequentemente, um novo levantamento da ocorrência e diversidade dessas espécies foi conduzido em algumas regiões brasileiras. Como nosso grupo de pesquisa possui um projeto de cooperação com a República Dominica, essas análises se expandiram para a esta região do Caribe, devido à recente epidemia de tospovírus lá instalada e a necessidade de monitoramento da dispersão de espécies de tospovirus e a busca por soluções desse novo quadro epidemiológico alarmante. Além disso, a recente introdução de diferentes espécies de tospovirus na República Dominicana constitui-se um excelente modelo para estudo de emergência e evolução de vírus de plantas, tomando como modelo os tospovirus.

Devido ao recente quadro de dispersão de TCSV nas Américas, sua proximidade taxônomica com GRSV e por constituírem o único relato de rearranjo inter-específico ocorrido naturalmente entre espécies de tospovírus $\left(\mathrm{S}_{\mathrm{GRSV}} \mathrm{M}_{\mathrm{TCSV}} \mathrm{L}_{\mathrm{GRSV}}\right)$, um desenho experimental de coinfecção (GRSV + TCSV) em plantas modelo de Nicotiana benthamiana foi elaborado, afim de observar o 'fitness' dessas espécies em um processo de co-infecção (de Ávila et al., 1993a; Webster et al., 2011; Londoño et al., 2012; Batuman et al., 2015). Além disso, um estudo de ancestralidade do RNA M de TCSV e GRSV foi realizado para o entendimento da origem desses segmentos.

Ainda, estudos de filogeografia foram realizados baseados em sequências da proteína $\mathrm{N}$ de isolados de espécies importantes de tospovirus e disponíveis no banco de dados (GenBank®). Estes estudos foram conduzidos para as espécies TCSV, TSWV e 
IYSV devido ao recente quadro de dispersão de TCSV nas Américas, a relevância de TSWV para o gênero tospovirus e IYSV ser a única espécie do clado asiático a ser encontrada em todos os continentes (Cortês et al., 1998; Pozzer et al., 1999; Ravi et al., 2006; Nischwitz et al., 2007; Krauthausen et al., 2012; Lodoño et al., 2012; Batuman et al., 2015; Fuji et al., 2015).

Dessa forma, o principal objetivo do trabalho é estudar a capacidade adaptativa e evolutiva de tospovírus, baseado na diversidade e distribuição geográfica, ocorrência natural de rearranjo e competição entre as espécies.

\section{Objetivos}

\subsection{Objetivo Geral}

Estudar a capacidade adaptativa e evolutiva de tospovírus baseado na ocorrência natural de rearranjo entre as espécies Groundnut ringspot virus (GRSV), Tomato chlorotic spot virus (TCSV), Tomato spotted wilt virus (TSWV) e na competição entre GRSV e TCSV. Conduzir o estudo em dois ambientes distintos, no Brasil onde os tospovírus já estão estabelecidos por um período longo de tempo, comparado à diversidade e dispersão de tospovírus na República Dominicana, considerada uma região emergente na infecção por tospovirus. Determinar a distribuição geográfica (filogeografia) de IYSV, TCSV e TSWV, importantes espécies de tospovirus detectados em várias regiões no mundo.

\subsection{Objetivos Específicos}

- Fazer o levantamento da presença de GRSV, TCSV e TSWV em regiões produtoras de espécies hortículas no Brasil e na República Dominicana;

- Verificar a ocorrência de rearranjos naturais entre GRSV, TCSV e TSWV nessas regiões geográficas distintas;

- Análisar o 'fitness' de GRSV e TCSV em infecção mista e da ancestralidade do RNA M dessas duas espécies;

- Estudar a filogeografia de TSWV, TCSV e IYSV. 


\section{CAPÍTULO 1: Ocorrência e dispersão de Groundnut ringspot virus (GRSV), Tomato chlorotic spot virus (TCSV) e Tomato spotted wilt virus (TSWV) submetidos a diferentes condições ambientais e pressão de seleção no Brasil e na República Dominicana}

\section{Introdução}

Tospovírus são bem adaptados às condições brasileiras, pois além do clima tropical favorável ao desenvolvimento de microrganismos e da presença de diversas espécies de plantas hospedeiras do vírus, no país já foram relatadas cinco espécies de tripes conhecidas como vetoras de tospovírus, Frankliniella occidentalis, F. schultzei, F. zucchini, Thrips tabaci e T. palmi (Nagata et al., 1995; Nagata et al., 1999; Monteiro, 2001). A grande capacidade de infecção e dispersão acarreta perdas anuais de produção avaliadas em milhões de dólares na cultura do tomateiro. O Brasil é conhecido por possuir uma grande diversidade de tospovírus, sendo relatado no país BeNMV, CSNV, GRSV, IYSV, TCSV, TSWV e ZLCV (de Ávila et al., 1993a; Bezerra et al., 1999; Pozzer et al., 1999; Oliveira et al., 2012). Apesar da diversidade e de condições ecológicas favoráveis ao estabelecimento das infecções virais, as espécies TSWV, GRSV e TCSV são as mais importantes no campo por causa das culturas que infectam, por partilharem importantes hospedeiras, como o tomateiro e por serem eficientemente transmitidas pelas espécies de tripes predominantes nas condições brasileiras, $F$. occidentalis e F. schultzei (Nagata et al., 1995).

TSWV é conhecido há muitos anos por causar a doença vira-cabeça do tomateiro que é relevante também em pimenteiras e batateiras e é considerada uma das principais doenças virais do Brasil, limitando a produção principalmente nos períodos mais quentes do ano, devido ao aumento da população do inseto vetor (Costa et al., 1941; de Ávila et al., 1996; Salgado et al., 1980; Lima et al., 2000). A doença pode causar prejuízos totais, destruindo a planta ou causando desvalorização dos frutos já formados pelos sintomas da doença (Salgado et al., 1980) (Figura 1). GRSV e TCSV foram relatados no país no início da década de 1990 em tomateiro, sendo atualmente disseminados pelo sul e sudeste dos Estados Unidos (GRSV e TCSV) e Caribe (TCSV) (de Ávila et al., 1993a; Boari et al., 2002; Webster et al., 2010; Webster et al., 2011; Eiras et al., 2012; Londoño et al., 2012; Webster et al., 2013; Batuman et al., 2015; Webster et al., 2015; Duarte et al., 2016). 
IYSV foi primeiramente descrito nos países baixos causando doença na planta ornamental Iris hollandica, sendo posteriormente relatado no Brasil causando perdas de até $100 \%$ na cultura da cebola no Vale do São Francisco, no norte de Minas Gerais e na região Nordeste (Cortês et al., 1998; Pozzer et al., 1999). CSNV foi relatado pela primeira vez no Brasil em crisântemo no estado de São Paulo, onde o cultivo e a produção de plantas ornamentais englobam altos investimentos financeiros. CSNV surgiu de forma epidêmica em plantas de crisântemo cultivadas em casas de vegetação, posteriormente se disseminou para o campo, infectando também tomateiro (Bezerra et al., 1999). O relato de CSNV não é restrito ao Brasil, sendo detectado também no Reino Unido, no Japão, Holanda, Slovenia a e na Bélgica, provavelmente disseminado via intercâmbio de material vegetal infectado (Duarte et al., 1995; Verhoven et al., 1996; Mumfort et al., 2003; Ravnikar et al., 2003; Takeshita et al., 2011; Jonghe et al., 2013; Dullemans et al., 2015). ZLCV foi descrito no Brasil em campos experimentais de Cucurbita pepo e é um tospovírus com distribuição e ciclo de hospedeiras bastante restritos. Essa espécie foi relatada somente no Brasil e infecta exclusivamente plantas da família Cucurbitaceae e alguns hospedeiros experimentais, como Nicotiana benthamiana e Gomphrena globosa (Bezerra et al., 1999). O BeNMV é um tospovírus brasileiro isolado de feijão comum (Phaseolus vulgaris) no estado de São Paulo, o qual também apresenta distribuição e ciclo de hospedeiras bastante limitados. BeNMV foi relatado somente no Brasil, infectando apenas uma cultivar de Phaseolus vulgaris (cultivar Santana) e a hospedeira experimental Datura stramonium (família Solanaceae) (Oliveira et al., 2012).

TCSV e TSWV foram relatados recentemente em países da região do Caribe. Na República Dominicana, TCSV e TSWV foram reportados em tomateiro, em Porto Rico TCSV foi encontrado infectando pimenta, D. stramonium, alface e também em tomateiro (Batuman et al., 2015; Webster et al., 2015). A recente disseminação de tospovírus pelo Caribe é acompanhada também pelos crescentes relatos de TCSV e GRSV nas regiões Sul e Sudeste dos Estados Unidos, infectando tomateiros e pimenteiras (Capsicum spp.) (Webster et al., 2010; Londoño et al., 2011; Webster et al., 2011; Webster et al., 2015).

A dispersão de tospovírus pelas Américas e principalmente nos Estados Unidos, foi proposta como fator causador do surgimento de um provável isolado híbrido de tospovírus, o qual é composto pelos RNAs S e L de GRSV e o RNA M de TCSV (Webster et al., 2011). Este tipo de composição genômica conhecida como rearranjo ainda não havia sido relatada na natureza entre espécies de tospovírus, mas apenas entre 
isolados de TSWV e, portanto, de uma mesma espécie viral. O possível isolado americano híbrido $\mathrm{S}_{\mathrm{GRSV}} \mathrm{M}_{\mathrm{TCSV}} \mathrm{L}_{\mathrm{GRSV}}$ está se disseminando no sul dos Estados Unidos e sendo tratado como um novo isolado de GRSV (Margaria et al., 2007; Tentchev et al., 2011; Webster et al., 2011; Webster et al., 2015). Portanto, baseado nessa nova combinação genômica encontrada no campo, e considerando, o principal critério taxonômico que utiliza a identidade da proteína $\mathrm{N}$ do RNA S para definir espécies, é possível que os estudos de diversidade genética de tospovírus tenham negligenciado a capacidade de geração de novas combinações virais. Portanto, as taxas de surgimento de novos rearranjos no campo, podem ser mais frequentes do que foi relatado até o momento, devido a não detecção de potenciais rearranjos genômicos ocorridos sob condições naturais de infecção por diferentes espécies de tospovírus (Webster et al., 2011).

No Brasil, devido às condições favoráveis, espera-se a ocorrência de isolados que sofreram rearranjo genômico sob condições de infecção múltipla. Além dos fatores ambientais, à exemplo do quadro de dispersão nos Estados Unidos, a competição entre as espécies por um novo nicho pode favorecer o aparecimento de rearranjos (Webster et al., 2015). Assim, a região do Caribe onde se constatou a introdução recente de diferentes espécies de tospovírus pode ser um 'hotspot' no surgimento de novos isolados rearranjados e até de novas espécies (Batuman et al., 2015; Webster et al., 2015). Neste capítulo, foram avaliados isolados de GRSV, TCSV e TSWV encontrados em plantas coletadas no Brasil e na República Dominicana quanto à composição dos segmentos de RNA. Assim, foi realizada uma amostragem da ocorrência de GRSV, TCSV e TSWV em regiões produtoras de hortaliças dos estados brasileiros de Goiás, São Paulo e Ceará e do Distrito Federal e de áreas agrícolas das províncias de La Vega, Monseñor Nouel e Santiago na República Dominicana (Figura 13). Por fim, A plataforma de sequenciamento de alto rendimento Ilumina Hiseq 2000 e o método Sanger 454, juntamente com os clássicos procedimentos de detecção viral (RT-PCR e serologia) foram utilizados na busca por possíveis genomas virais nas amostras das províncias da República Dominicana. 
(a) Arachis hypogea

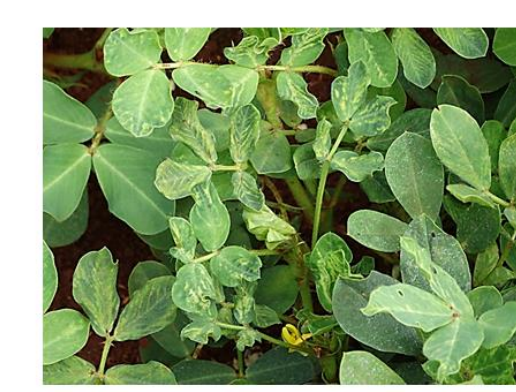

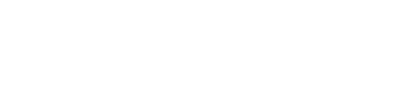
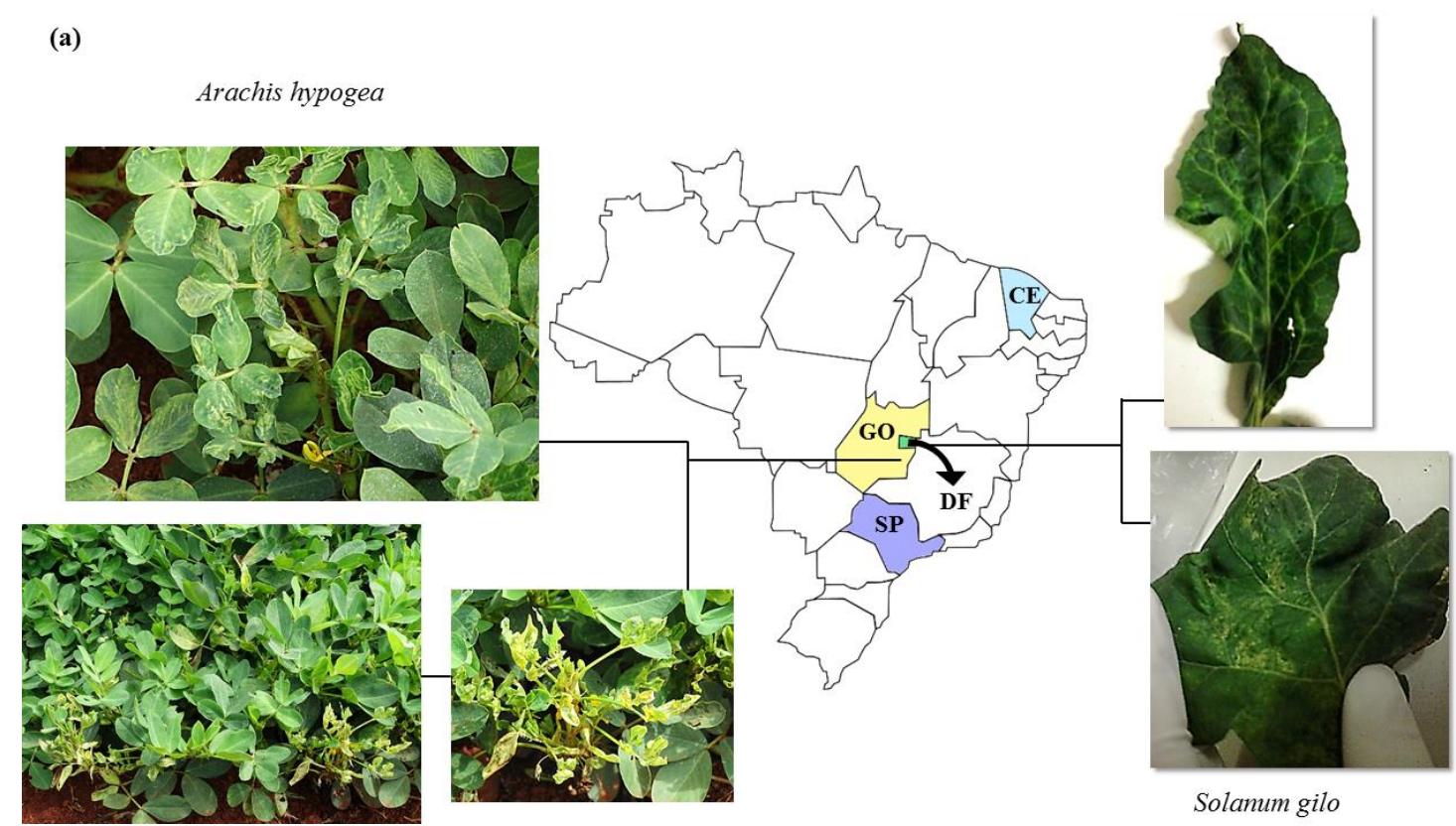

Solanum gilo

(b)
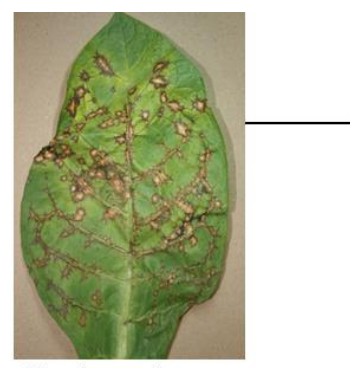

Nicotiana tabacum

Solanum tuberosum

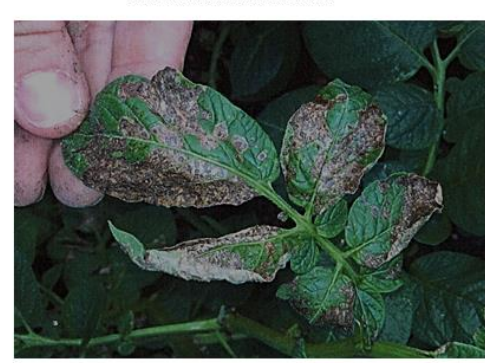

Província de Santiago
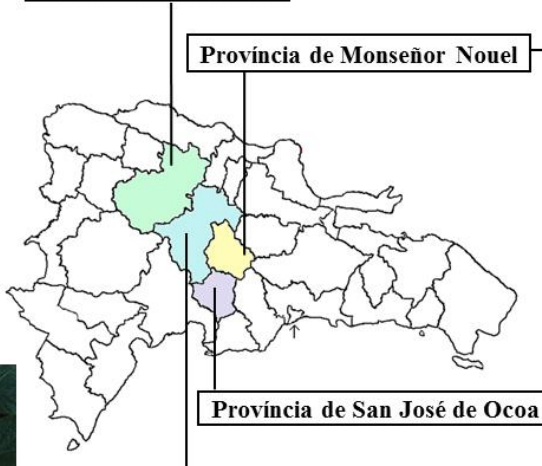

Província de La Vega

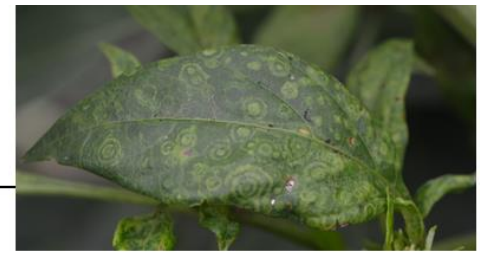

Capsicum annuum
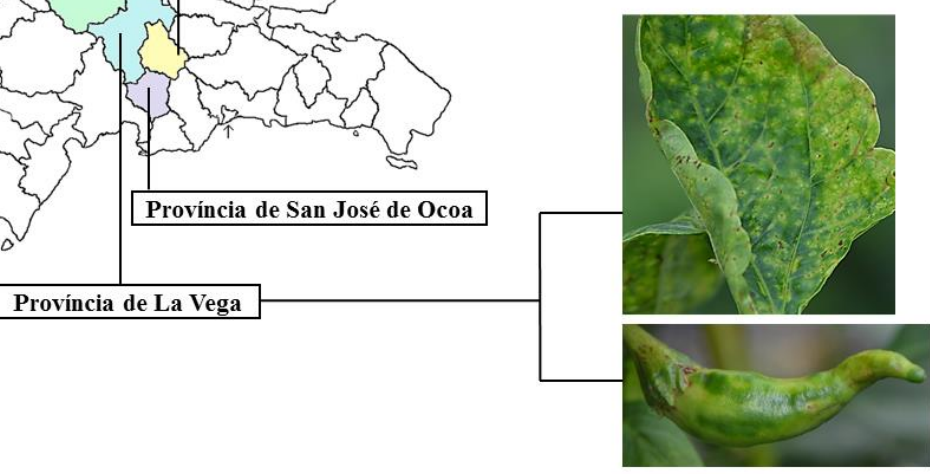

Capsicum frutescens

Figura 13. Regiões de coleta (áreas coloridas) das amostras analisadas quanto à presença e composição dos tospovírus Groundnut ringspot virus (GRSV), Tomato chlorotic spot virus (TCSV) e Tomato spotted wilt virus (TSWV) no Brasil (a) e na República Dominicana (b). Na amostragem do Brasil (a), o jiló (Solanum gilo) foi coletado no Distrito Federal com forte clareamento de nervuras e pequenos anéis cloróticos e necróticos no limbo foliar. Plantas de amendoim (Arachis hypogea) foram encontradas no estado do Goiás com forte clareamento de nervuras e anéis cloróticos. Na República Dominicana (b), pimenta-doce (Capsicum annuum) foi coletada com típicos sintomas de tospovírus, os anéis cloróticos concêntricos. Os frutos da pimenta-picante (Capsicum frutescens) amostrada estavam deformados e impróprios para o comércio. As folhas da batateira (Solanum tuberosum) coletada na província de La Vega apresentavam muitos anéis necróticos, comprometendo grande parte do limbo foliar. Folhas de tabaco (Nicotiana tabacum) da província de Santiago expunham pálidos anéis necróticos, o que prejudica a comercialização do produto. 


\section{Metodologia}

A primeira etapa do trabalho foi identificar a presença dos tospovírus Groundnut ringspot virus (GRSV), Tomato chlorotic spot virus (TCSV) e Tomato spotted wilt virus (TSWV) e a composição genômica (identidade dos RNA L, M e S) dos isolados. Para tanto, foram coletadas amostras de plantas com sintomas semelhantes aos causados por tospoviroses em regiões de produção agrícola no Brasil e na República Dominicana (Figura 13). No total, foram coletadas 166 amostras distribuídas nas famílias Solanaceae, Fabaceae, Asteraceae, Alliaceae e Chenopodiaceae entre os anos de 2013 e 2016. As amostras foram coletadas de forma aleatória, principalmente em campo aberto. Amostras provenientes de cultivo protegido foram coletadas apenas na República Dominicana. Os sintomas observados para as coletas foram clareamento de nervuras, nanismo, deformação da planta, enrolamento dos ponteiros, necrose no limbo foliar e no caule, anéis necróticos e cloróticos na epiderme da folha. O principal foco das coletas foi em plantas solanáceas, com ênfase no tomateiro.

Os RNAs totais das 166 amostras coletadas foram extraídos pelo método Trizol ${ }^{\circledR}$ (Invitrogen), seguindo as especificações do fabricante. A integridade dos RNAs extraídos foi verificada por eletroforese em gel de agarose. A presença dos RNAs ribossomais $18 \mathrm{~S}(\sim 2 \mathrm{~kb})$ e $28 \mathrm{~S}(\sim 4.5 \mathrm{~kb})$ intactos nas amostras foi o critério de avaliação da qualidade das mesmas, pois são os tipos mais comuns de RNA encontrados no citoplasma (Figura 14). A identificação e composição viral nessas amostras foram feitas por marcadores moleculares específicos. Inicialmente, todas as amostras foram testadas com um par de primers sintetizados a partir de uma região conservada do RNA L de GRSV, TCSV e TSWV, visando realizar uma seleção primária de amostras com tospoviroses. Em seguida, as amostras positivas foram avaliadas com primers espécieespecíficos para detectar os RNAs S, M e L de GRSV, TCSV e TSWV, separadamente.

Algumas amostras coletadas na República Dominicana foram selecionadas para o sequenciamento de alta performance por meio da plataforma Ilumina Hiseq 2000 para identificação ampla dos possíveis vírus presentes. Após o sequenciamento extensivo, reações de PCR com primers específicos foram realizadas e seus produtos sequenciados para confirmação dos genomas encontrados no sequenciamento de alta performance. 


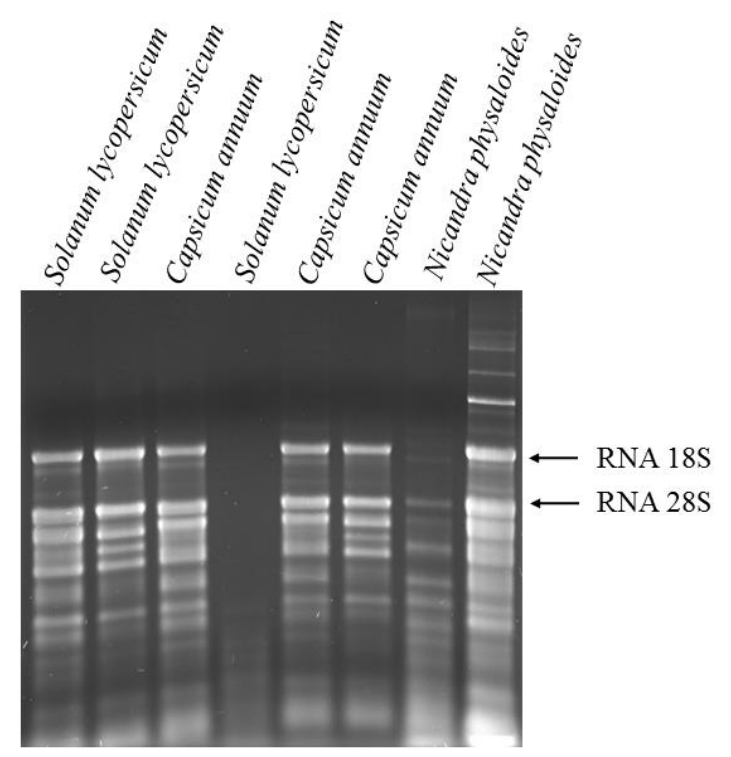

Figura 14. Perfil de um gel de agarose $1 \%$ usado para verificar integridade do RNA total de plantas infectadas e sadias extraídos pelo método Trizol $^{\circledR}$. As múltiplas bandas correspondem às diferentes moléculas de RNA presentes nas células. As setas pretas indicam as bandas referentes aos RNAs 18S $(\sim 2 \mathrm{~Kb})$ e $28 \mathrm{~S}(\sim 4.5 \mathrm{~kb})$, os quais são mais abundantes no citoplasma e utilizados como critério de qualidade.

\subsection{Desenvolvimento de marcadores moleculares para deteç̧ão simultânea e} espécie-específica das espécies Groundnut ringspot virus (GRSV), Tomato chlorotic spot virus (TCSV) e Tomato spotted wilt virus (TSWV)

Sequências de nucleotídeos dos RNAs S, M e L de GRSV, TCSV e TSWV disponíveis nos bancos de dados (GenBank®) foram alinhadas com o programa DNAMAN v.4 Lynnon Biosoft. (Tabela 7). Primeiramente, com os alinhamentos múltiplos entre os RNAs L e M dos três tospovírus, foram selecionadas sequências conservadas entre as três espécies, para a síntese de primers de detecção simultânea de GRSV, TCSV e TSWV. 
Tabela 7. Sequências de nucleotídeos utilizadas para sintetizar os primers de detecção simultânea e espécie-específica de Groundnut ringspot virus (GRSV), Tomato chlorotic spot virus (TCSV) e Tomato spotted wilt virus (TSWV). Números de acessos das sequências disponibilizadas pelo banco de dados GenBank® do National Center for Biotechnology Information (NCBI)

\begin{tabular}{ccc}
\hline Sequência & Tospovírus & Número de Acesso \\
\hline RNA S & GRSV & AF513219 \\
& TCSV & AF282982 \\
& TSWV & D00645 \\
RNA M & GRSV & AY575055 \\
& TCSV & AY574054 \\
& TSWV & S48091 \\
RNA L & GRSV & HQ634679 \\
& TCSV & HQ700667 \\
& TSWV & D10066 \\
\hline
\end{tabular}

Primers espécie-específicos foram desenhados por meio da escolha de regiões variáveis e específicas entre as espécies. As sequências foram selecionadas quanto ao tamanho e número de nucleotídeos idênticos (primers de detecção simultânea) ou diferentes (primers espécie-específicos). As sequências escolhidas foram analisadas quanto à porcentagem dos nucleotídeos guanina e citosina (GC\%), temperatura de 'melting' e a entropia necessária para que ocorra a formação de dímeros de primers, visando a otimização das reações de PCR. As análises dos oligonucleotídeos foram realizadas com a ferramente OligoAnayzer 3.1, disponibilizada pela 'Integrated DNA Technologies' (IDT) (https://www.idtdna.com/calc/analyzer). A porcentagem de GC foi admitida entre 40-65\%, pois nas sequências dos RNAs de tospovírus as quantidades de adenina (A) e uracila (U) são maiores, e a temperatura de 'melting' entre $45-65^{\circ} \mathrm{C}$. Após essas duas análises, foi verificada a entropia $(\Delta \mathrm{G})$ das sequências para predizer as chances dos oligonucleotídeos se ligarem entre si. Para este critério foram aceitos valores de entropia $(\Delta G)$ entre 0 - $(-8)$, pois valores menores indicam mais energia livre para que ocorram ligações intermoleculares, ou seja, a formação de dímeros entre os primers (Tabela 8, Tabela 9). 
Tabela 8. Oligonucleotídeos selecionados após alinhamento múltiplo dos RNAs S, M e L de Groundnut ringspot virus (GRSV), Tomato chlorotic spot virus (TCSV) e Tomato spotted wilt virus (TSWV) para síntese dos primers espécie-específicos dos segmentos genômicos de GRSV, TCSV e TSWV. Temperatura de melting $\left(\mathrm{T}_{\mathrm{m}}\left[\mathrm{C}^{\circ}\right]\right)$ dos primers e local de anelamento no genoma são fornecidos na tabela. $\mathrm{Np}$ = nucleoproteína, $\mathrm{Gp}$ = glicoproteína, $\mathrm{RdRp}=$ polimerase e NSs = proteína não estrutural do RNA S

\begin{tabular}{|c|c|c|c|c|c|}
\hline Tospovírus & RNA & $\begin{array}{c}\text { Nome } \\
\text { do primer }\end{array}$ & Sequência 5' - 3' (17-25nts) & $\begin{array}{c}\mathrm{T}_{\mathrm{m}} \\
{\left[\mathrm{C}^{\circ}\right]}\end{array}$ & $\begin{array}{c}\text { Posição no } \\
\text { genoma } \\
5^{\prime}-3^{\prime}\end{array}$ \\
\hline \multirow[t]{10}{*}{ GRSV } & \multirow[t]{2}{*}{$\mathrm{S}$} & GRSV-S_For & CTGTCAGGAAAATCTTGACCTG & 53.5 & $\begin{array}{c}\mathrm{Np} \\
\mathrm{nt} 111-132\end{array}$ \\
\hline & & GRSV-S_Rev & ACGAGATGTTTGGAGTCAAG & 52.5 & $\begin{array}{c}\mathrm{Np} \\
\mathrm{nt} 728-747\end{array}$ \\
\hline & \multirow[t]{6}{*}{ M } & GRSV-M_For & AGCCGATTTGTCACCAC & 52.9 & $\begin{array}{c}\mathrm{Gp} \\
\mathrm{nt} 2869-2885\end{array}$ \\
\hline & & GRSV-M_Rev & GTCGATATCCCTTTGACCTCG & 54.8 & $\begin{array}{c}\mathrm{Gp} \\
\mathrm{nt} 3353-3373\end{array}$ \\
\hline & & GRSV-M2_For & GTGAGCTATTAGTTCGCCGACG & 57.7 & $\frac{\mathrm{Gp}}{\mathrm{nt} 1324-1342}$ \\
\hline & & GRSV-M2_Rev & AGAGGTTGAAAATACCAGGTCC & 60.3 & $\begin{array}{c}\text { Gp } \\
\text { nt868-889 }\end{array}$ \\
\hline & & GRSV-M3_For & TTGCCTTAACAGGTAATTAAAGC & 57.5 & $\underset{\mathrm{nt} 1-23}{\mathrm{Gp}}$ \\
\hline & & GRSV-M3_Rev & GTGAGCTATTAGTTCGCCGACG & 64 & $\begin{array}{c}\mathrm{Gp} \\
\text { nt1321-1342 }\end{array}$ \\
\hline & \multirow[t]{2}{*}{$\mathrm{L}$} & GRSV-L_For & CCATTGAGGACTGTGTAGG & 52.3 & $\begin{array}{c}\text { RdRp } \\
\text { nt90-109 }\end{array}$ \\
\hline & & GRSV-L_Rev & GATGATCTACGACTGGAAG & 49.3 & $\begin{array}{c}\text { RdRp } \\
\text { nt577-595 }\end{array}$ \\
\hline \multirow[t]{8}{*}{ TCSV } & \multirow[t]{2}{*}{$\mathrm{S}$} & TCSV-S_For & AACTGGGAAAGCAGAAAACC & 53.5 & $\begin{array}{c}\mathrm{Np} \\
\mathrm{nt} 321-340\end{array}$ \\
\hline & & TCSV-S_Rev & TGCAATGTTCGGAGTAAGG & 52.5 & $\begin{array}{c}\mathrm{Np} \\
\text { nt729-747 }\end{array}$ \\
\hline & \multirow[t]{4}{*}{ M } & TCSV-M_For & GCAAGATTCCATAGAGATTG & 48.3 & $\begin{array}{c}\text { Gp } \\
\text { nt853-872 }\end{array}$ \\
\hline & & TCSV-M_Rev & TTGCTTCAGAGAGTCTCC & 51 & $\begin{array}{c}\mathrm{Gp} \\
\mathrm{nt} 1930-1947\end{array}$ \\
\hline & & TCSV-M2_For & GGAAGATAAAGGCTATAAGCAG & 58 & $\underset{\mathrm{Gt}}{\mathrm{Gp}}$ \\
\hline & & TCSV-M2_Rev & AGTCCCGAAAATGCTTTCTAC & 57 & $\begin{array}{c}\text { Gp } \\
\text { nt2209-2229 }\end{array}$ \\
\hline & \multirow[t]{2}{*}{$\mathrm{L}$} & TCVS-L_For & ATGTTCGGTGGGCTGGTGTC & 60 & $\begin{array}{c}\text { RdRp } \\
\text { nt344-363 }\end{array}$ \\
\hline & & TCSV-L_Rev & GGGAAGCATCTAGGGAAAATTATG & 53.6 & $\begin{array}{c}\text { RdRp } \\
\text { nt1280-1303 }\end{array}$ \\
\hline \multirow[t]{8}{*}{ TSWV } & \multirow[t]{2}{*}{$\mathrm{S}$} & TSWV-S_For & CCCTGTGAAGAAGAAGAGATTTC & 53.2 & $\begin{array}{c}\text { Nss } \\
\text { nt283-305 }\end{array}$ \\
\hline & & TSWV-S_Rev & GATGTGCTATAATCAGGCTTTAGGC & 55.7 & $\begin{array}{c}\text { Nss } \\
\text { nt701-725 }\end{array}$ \\
\hline & \multirow[t]{4}{*}{ M } & TSWV-M_For & CGATTAATGTAGGAGATAGGATC & 49 & $\begin{array}{c}\mathrm{Gp} \\
\mathrm{nt} 1235-1257\end{array}$ \\
\hline & & TSWV-M_Rev & GCTCTAAACCAGATCTAAATCTG & 50 & $\begin{array}{c}\text { Gp } \\
\text { nt2052-2074 }\end{array}$ \\
\hline & & TSWV-M2_For & GGCTTTGATCTCAGAATC & 47.6 & $\begin{array}{c}\mathrm{Gp} \\
\mathrm{nt} 1349-1365\end{array}$ \\
\hline & & TSWV-M2_Rev & AATCCTTGAGCATTGAC & 51 & $\begin{array}{c}\mathrm{Gp} \\
\mathrm{Nt} 2368-2384\end{array}$ \\
\hline & \multirow[t]{2}{*}{$\mathrm{L}$} & TSWV-L_For & CTGTTGTCTATTGAGGATTGTG & 51.2 & $\begin{array}{c}\text { RdRp } \\
\text { nt82-103 }\end{array}$ \\
\hline & & TSWV-L_Rev & GTCCTGCATTAACAAGCTCTCTG & 47.8 & $\begin{array}{c}\text { RdRp } \\
\text { nt475-453 }\end{array}$ \\
\hline
\end{tabular}


Tabela 9. Primers degenerados sintetizados para detecção simultânea de Groundnut ringspot virus (GRSV), Tomato chlorotic spot virus (TCSV) e Tomato spotted wilt virus (TSWV). Temperatura de melting $\left(\mathrm{T}_{\mathrm{m}}\left[\mathrm{C}^{\circ}\right]\right)$ dos primers e local de anelamento no genoma são fornecidos na tabela. $\mathrm{Np}=$ nucleoproteína, $\mathrm{Gp}=$ glicoproteína, $\mathrm{RdRp}=$ polimerase e NSs = proteína não estrutural do RNA $\mathrm{S}$

\begin{tabular}{|c|c|c|c|c|c|}
\hline Tospovírus & RNA & Nome do primer & Sequência 5' - 3' (18-25nts) & $\mathrm{T}_{\mathrm{m}}\left[\mathrm{C}^{\circ}\right]$ & $\begin{array}{l}\text { Posição no genoma } \\
5^{\prime}-3^{\prime}\end{array}$ \\
\hline \multirow{4}{*}{$\begin{array}{l}\text { GRSV } \\
\text { TCSV }\end{array}$} & \multirow[t]{4}{*}{$\mathrm{M}$} & Tospo_For & CTTCKTCTYGCTATDGTR & 52.6 & $\begin{array}{c}\mathrm{Gp} \\
\mathrm{nt} 1313-1330\end{array}$ \\
\hline & & Tospo_Rev & DCCYAAAGARCTTCCTGT & 54.9 & $\begin{array}{c}\text { Gp } \\
\text { nt2989-3006 }\end{array}$ \\
\hline & & TospouniFor & AAATAAGGCTGAAAAGCCAAA & 51 & $\begin{array}{c}\text { Gp } \\
\text { nt1130-1150 }\end{array}$ \\
\hline & & TospouniRev & CCATCATTRTGCARAATCTGC & 54.5 & $\begin{array}{c}\text { Gp } \\
\text { nt2400-2419 }\end{array}$ \\
\hline \multirow{2}{*}{ TSWV } & \multirow[t]{2}{*}{$\mathrm{L}$} & TospoF2L & GGTTCTAACCACGACCTAGC & 55 & $\begin{array}{c}\text { RdRp } \\
\text { nt104-123 }\end{array}$ \\
\hline & & TospoR2L & ATGATGAGTTTGAGAGGATA & 47.7 & $\begin{array}{c}\text { RdRp } \\
\text { nt474-495 }\end{array}$ \\
\hline
\end{tabular}

Observação: As letras K, Y, D e R nas sequências dos primers são símbolos para representar que diferentes oligonucleotídeos compõem a solução do primer. Nas posições dessas consoantes foram inseridas de forma alternada as bases nitrogenadas Adenina (A), Guanina (G), Timina (T) e Citosina (C). Assim, a solução do primer degenerada é composta por variadas moléculas. A letra K pode ser substituída por Timina (T) ou Guanina (G), Y significa Citosina (C) ou Timina (T) na posição, o símbolo D traduz que nesta posição parte dos oligonucleotídeos possui A, outra parte possui G e uma outra porção T, por fim, a letra R representa Adenina (A) e Timina (T) na posição.

Os RNAs totais de folhas de Nicotiana spp. e Datura stramonium infectadas com isolados de BeNMV, CSNV, GRSV, TCSV, TSWV e ZLCV foram extraídos pelo método Trizol ${ }^{\circledR}$ (Invitrogen) para serem usados como 'template' nas reações de RTPCR. Os vírus foram cedidos pela Dra. Alice Nagata do Centro Nacional de Pesquisa em Hortaliças (CNPH).

As reações de transcriptase reversa com a enzima M-MLV foram testadas com temperaturas de síntese da fita complementar de DNA (cDNA) à $37^{\circ} \mathrm{C}$ e à $42^{\circ} \mathrm{C}$. A enzima Superscript III $^{\circledR}$ (SSIII) foi utilizada apenas para as reações específicas por se tratar de uma enzima mais eficiente. As reações com SSIII foram testadas nas temperaturas de 55 e $58^{\circ} \mathrm{C}$. As reações de RT-PCR foram conduzidas em duas etapas. A primeira etapa é de desnaturação e foi utilizado $1 \mu 1$ de cada primer ('forward' e reverso) [10uM], $1 \mu 1$ solução de dNTPs [10mM] [2,5mM de cada dNTP], $2 \mu 1$ RNA molde [0.5$2 \mu \mathrm{g}]$ e $13 \mu \mathrm{l}$ de água estéril para a etapa de desnaturação $\left(70^{\circ} \mathrm{C}-5\right.$ minutos; gelo - 1 minuto). Ao termino da primeira etapa, foi acrescentado a segunda reação para síntese dos cDNAs. Na segunda etapa foi utilizado $2 \mu 1$ do tampão da enzima 'First Strand' $[5 \mathrm{x}], 1 \mu \mathrm{l}$ do agente redutor DTT (DL-Ditiotreitol) $[0.1 \mathrm{M}]$ para estabilizar a enzima, $0.5 \mu 1$ de enzima (M-MLV ou Superscript III ${ }^{\circledR}$ ) [200 unids./ $\left.\mu 1\right]$, completando o volume 
final de $7 \mu 1$ por reação com água estéril (ajustar temperatura de síntese -1 hora; $70^{\circ} \mathrm{C}-$ 15 minutos, desnaturação final).

As reações de PCR foram feitas com a enzima Taq Platinum $^{\circledR}$ DNA polymerase (Invitrogen). Um gradiente de temperatura $\left(55-65^{\circ} \mathrm{C}\right)$ foi aplicado por "corrida" para determinar as temperaturas ótimas de anelamento dos primers. As reações foram montadas com $1.5 \mu 1$ de $\mathrm{MgCl}_{2}$ [50Mm], 2.5 $\mu 1$ de tampão 10x da enzima, $1 \mu 1$ primer forward $[10 \mathrm{uM}], 1 \mu \mathrm{l}$ primer reverso $[10 \mu \mathrm{M}], 1 \mu 1$ solução de dNTPs $[10 \mathrm{mM}][2,5 \mathrm{mM}$ de cada dNTP], $0.2 \mu 1$ de enzima, $1 \mu 1$ de cDNA e $16.8 \mu 1$ de água estéril. As reações ficaram 3 minutos à $94^{\circ} \mathrm{C}$ para desnaturação inicial das moléculas, seguindo para um ciclo de $94^{\circ} \mathrm{C}$ por 30 segundos, gradiente de $55-65^{\circ} \mathrm{C}$ por 30 segundos e $72^{\circ} \mathrm{C}$ por um minuto para extensão, ciclo que se repetiu por 35 vezes e por fim foram submetidas a extensão final de cinco minutos de duração à $72^{\circ} \mathrm{C}$. Os fragmentos de PCR amplificados foram clonados no vetor pGEM $^{\circledR}$ T-Easy (Promega) e sequenciados automaticamente na Macrogen Inc. (Coréia do Sul). 


\subsection{Metagenômica na identificação de genomas virais em plantas cultivadas na República Dominicana}

A primeira biblioteca de cDNA foi construída com o 'pool' do RNA total de amostras de tomateiro, batateira, pimenteiras e feijoeiro, província de La Vega, e de pimenteiras, província de Monsenhor Nouel, República Dominicana. O agrupamento desses RNAs compôs uma única amostra, RD1. A segunda biblioteca, ou amostra RD2, foi preparada apenas com RNA total extraído de tomateiro da província de Ocoa com sintoma diferenciado. Os 'reads' obtidos no sequenciamento foram montados utilizando o programa CLC Genomic Workbench v. 6.0.3 e as sequências resultantes foram submetidas à análise no banco de dados GeneBank® por meio da ferramenta BLASTx. Todos os RNAs isolados para o sequenciamento de nova geração (NGS) foram extraídos com o kit mirVana ${ }^{\mathrm{TM}}\left(\right.$ Ambion $\left.^{\mathrm{TM}}\right)$ para garantir mais qualidade à amostra final. Para confirmar os resultados obtidos no NGS, todas as sequências virais relevantes encontradas nas amostras da República Dominicana foram rastreadas de volta por meio da RT-PCR com primers específicos. O 'template' de cada reação foi apenas um único RNA que compôs o 'pool' da amostra RD1 sequenciada por NGS.

\section{Resultados}

\subsection{Validação dos primers}

Os primers listados nas Tabelas 8 e 9 foram testados sob diferentes temperaturas de anelamento, utilizando como moldes ('template') RNAs totais extraídos de plantas com suspeita de infecção causada por tospovírus. Os pares de primers mais eficientes foram selecionados para detecção simultânea de GRSV, TCSV e TSWV e para identificação específica dos três segmentos de RNA de GRSV, TCSV e TSWV.

Os primers TospoF2L e TospoR2L feitos a partir do anelamento múltiplo dos RNAs L das três espécies de tospovírus apresentaram o espectro amplo de detecção de GRSV, TCSV e TSWV. Submetidos à RT-PCR com a enzima M-MLV (Invitrogen) à $42^{\circ} \mathrm{C}$, os primers TospoF2L e TospoR2L amplificaram as espécies GRSV, TCSV e TSWV na reação em cadeia da polimerase (PCR) com temperatura de $55^{\circ} \mathrm{C}$, perdendo a eficiência de amplificação a temperaturas mais altas. A partir de $58^{\circ} \mathrm{C}$ a amplificação foi limitada às espécies GRSV e TCSV (Figura 15). 
(a)

(b)
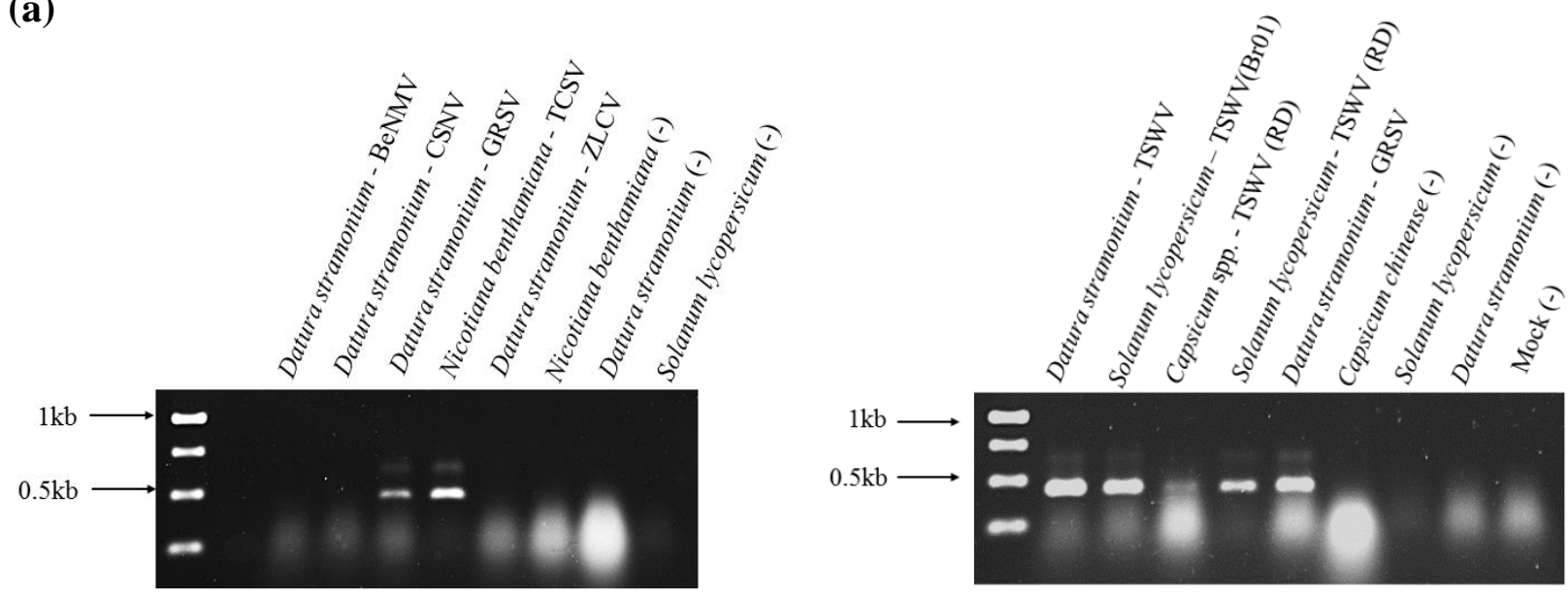

(c)

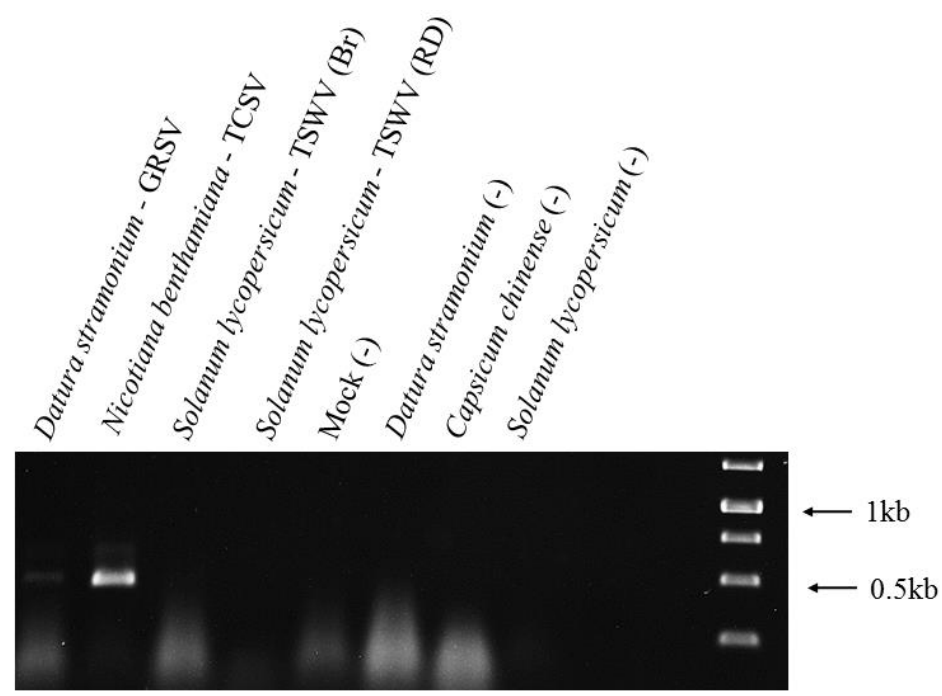

Figura 15. Validação do par de primers 'forward' TospoF2L e 'reverse' TospoR2L para detecção simultânea de Groundnut ringspot virus (GRSV), Tomato chlorotic spot virus (TCSV) e Tomato spotted wilt virus (TSWV). Reações de transcrição reversa (RT) feitas com M-MLV à $42^{\circ} \mathrm{C}$. (a) e (b) temperaturas de anelamento na reação de PCR a $55^{\circ} \mathrm{C}$ e (c) $58^{\circ} \mathrm{C}$. Para as reações foram utilizados como 'template' RNAs totais de Datura stramonium infectada com Bean necrotic mosaic virus (BeNMV), D. stramonium infectada com Chrysanthemum stem necrosis virus (CSNV), D. stramonium com Zucchini lethal chlorosis virus (ZLCV), Nicotiana benthamiana com TCSV, D. stramonium com TSWV, Capsicum spp. com TSWV, Solanum lycopersicum com TSWV e D. stramonium com GRSV.

As reações de transcrição reversa (RT) com enzima Super Script III ${ }^{\circledR}$ foram conduzidas à $55^{\circ} \mathrm{C}$ e $58^{\circ} \mathrm{C}$. A maioria dos pares de primers para detecção específica foi utilizada em reações de RT à $55^{\circ} \mathrm{C}$, apenas os pares para detecção dos RNAs M de GRSV e TCSV foram submetidos à temperatura mais elevada de $58^{\circ} \mathrm{C}$. Atingir a especificidade na detecção dos RNAs M de GRSV e TCSV foi desafiador, sendo os resultados pouco satisfatórios. 
Os primers específicos foram submetidos a um gradiente de temperatura na reação em cadeia da polimerase (PCR), sendo possível determinar a extensão de amplificação dos mesmos. O par de primers para detecção dos RNAs S (TSWV-S_For e TSWV-S_Rev) e M (TSWV-M2_For e TSWV-M2_Rev) de TSWV foram específicos na PCR com anelamento de $60^{\circ} \mathrm{C}$. O par para detecção do RNA L (TSWV-L_For e TSWV-L_Rev) foi específico na PCR com anelamento de $65^{\circ} \mathrm{C}$ (Figura 16a).

(a)
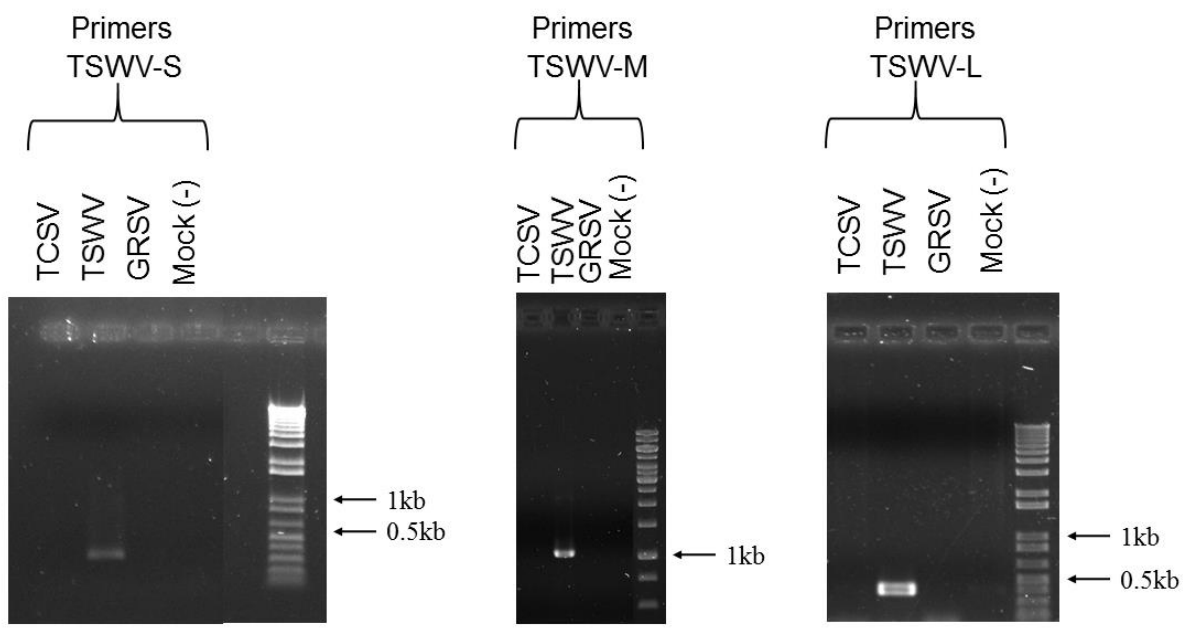

(b)

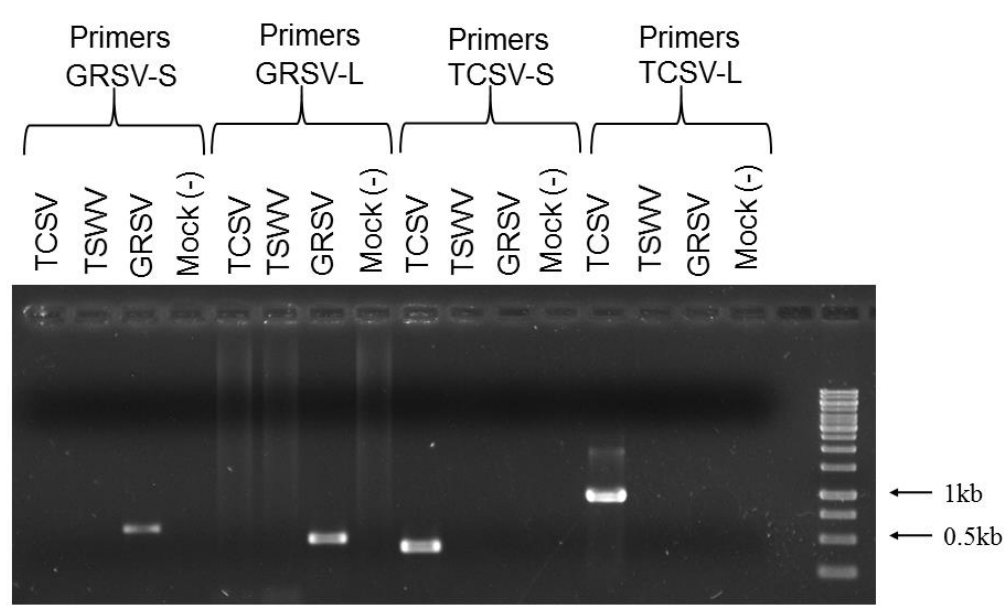

Figura 16. (a) Amplificação específica dos primers para detecção dos segmentos S, M e L de Tomato spotted wilt virus (TSWV) a partir de cDNAs produzidos à $55^{\circ} \mathrm{C}$. Os pares TSWV-S_For + TSWVS_Rev e TSWV-M2_For + TSWV-M2_Rev foram específicos à $60^{\circ} \mathrm{C}$ (RNAs S e M, respectivamente) e o par TSWV-L_For + TSWV-L_Rev à $65^{\circ} \mathrm{C}$ (RNA L). (b) Amplificação específica dos pares de primers GRSV-S_For + GRSV-S_Rev e GRSV-L_For + GRSV-L_Rev à $60^{\circ} \mathrm{C}$ para identificação dos segmentos S e L de Groundnut ringspot virus (GRSV), respectivamente. Os pares de primers TCSV-S_For + TCSVS_Rev e TCSV-L_For + TCSV-L_Rev amplificaram fragmentos dos RNAs S e L, respectivamente, Tomato chlorotic spot virus (TCSV) à $65^{\circ} \mathrm{C}$, com cDNAs produzidos à $55^{\circ} \mathrm{C}$. Marcador de peso molecular: GeneRuler 1kb Ladder, Thermo Scientific. 
O par para detecção do RNA S de GRSV (GRSV-S_For e GRSV S_Rev) foi específico à $60^{\circ} \mathrm{C}$ e do RNA L (GRSV-L_For e GRSV-L_Rev) foi específico entre as temperaturas de anelamento de $60-63^{\circ} \mathrm{C}$, com cDNA obtido na reação de RT à $55^{\circ} \mathrm{C}$ (Figura 16b). Os pares para detecção do RNA S de TCSV (TCSV-S_For e TCSVS_Rev) foi específico a $65^{\circ} \mathrm{C}$ e do RNA L (TCSV-L_For e TCSV-L_Rev) foi específico entre $55-65^{\circ} \mathrm{C}$, ambas as reações utilizaram como 'template' cDNAs produzidos à $55^{\circ} \mathrm{C}$ (Figura 16b). Quanto aos primers sintetizados para a detecção dos RNAs M de GRSV e TCSV, os cDNAs foram obtidos nas reações de transcrição reversa à $55^{\circ} \mathrm{C}$ e $58^{\circ} \mathrm{C}$, respectivamente. Os pares para detecção do RNA M de GRSV não amplificaram o segmento esperado com cDNA produzido à $58^{\circ} \mathrm{C}$. O par GRSV-M_For e GRSV-M_Rev não atingiu a especificidade desejada, amplificando também o TCSV, mesmo à $60^{\circ} \mathrm{C}$ (Figura 17a). Outros pares de primers utilizados como os GRSV-M3_For + GRSVM2_Rev e GRSV-M3_For + GRSV-M3_Rev não amplificaram os segmentos esperados (Tabela 8). Os pares de primers para detecção do RNA M de TCSV produziram as amplificações esperadas com cDNAs feitos à 55 e $58^{\circ} \mathrm{C}$. Contudo, esses pares não foram específicos e amplificaram o segmento M de GRSV. A amplificação inespecífica de GRSV pelo par TCSV-M_For e TCSV-M_Rev foi significativamente baixa apenas à $63^{\circ} \mathrm{C}$ (Figura 17b). O par TCSV-M2_For e TCSV-M2_Rev não foi específico mesmo à altas temperaturas de anelamento na PCR. Após a realização de todas as reações de RT e PCR em diferentes temperaturas e combinações de primers, determinando a especificidade dos primers testados, foi possível selecionar um par de primers para detecção de cada segmento de RNA genômico (S, M e L) de TSWV. Os segmentos S e L de GRSV e TCSV foram distinguíveis na PCR, contudo não foi possível detectar especificamente o segmento M dessas duas espécies (Tabela 10) (Figura 18). 
(a)

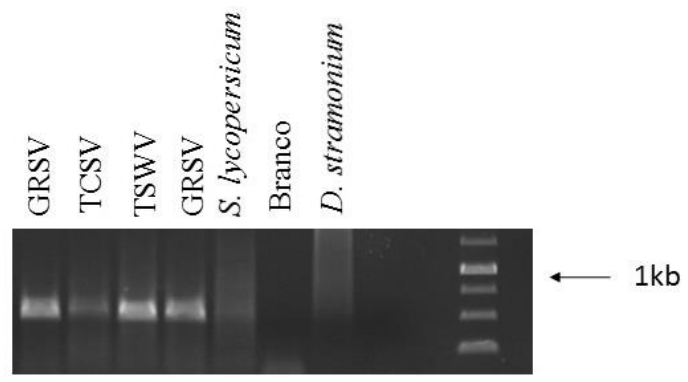

(b)

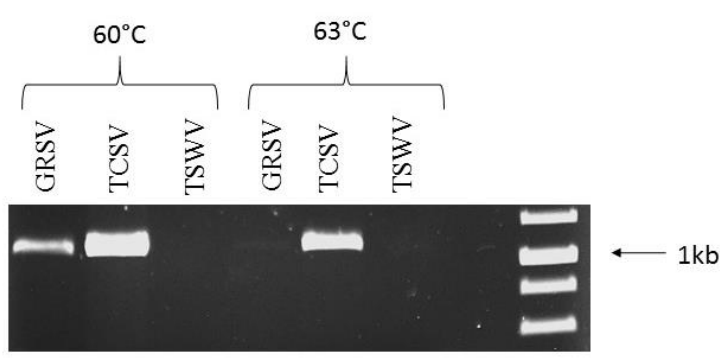

Figura 17. Otimização de primers para amplificação de espécies de tospovirus. (a) Amplificação inespecífica do par de primers GRSV-M_For + GRSV-M_Rev (RNA M) de Groundnut ringspot virus (GRSV) à $60^{\circ} \mathrm{C}$ a partir de cDNAs produzidos à temperatura de $55^{\circ} \mathrm{C}$. (b) Amplificação inespecífica do par de primers TCSV-M_For + TCSV-M_Rev (RNA M) de TCSV à 60 e $63^{\circ}$ C, a partir de cDNAs produzidos à $58^{\circ} \mathrm{C}$. Marcador de peso molecular: GeneRuler $1 \mathrm{~kb}$ Ladder, Thermo Scientific.

Tabela 10. Primers sintetizados para detecção ampla (*) e específica via RT-PCR dos tospovírus Groundnut ringspot virus (GRSV), Tomato chlorotic spot virus (TCSV) e Tomato spotted wilt virus (TSWV). Temperaturas de anelamento testadas para garantir especificidade com os respectivos tamanhos esperados dos segmentos amplificados estão representados na tabela

\begin{tabular}{|c|c|c|c|c|c|}
\hline Tospovírus & RNA & $\begin{array}{c}\text { Nome } \\
\text { do primer }\end{array}$ & Sequência 5' - 3' (17-25nts) & $\begin{array}{l}\text { Anelamento } \\
\text { PCR }\left[\mathrm{C}^{\circ}\right] \\
\end{array}$ & $\begin{array}{c}\text { Amplicon } \\
(\mathrm{pb})\end{array}$ \\
\hline \multirow[t]{2}{*}{ GRSV } & S & $\begin{array}{l}\text { GRSV-S_For } \\
\text { GRSV-S_Rev }\end{array}$ & $\begin{array}{c}\text { CTGTCAGGAAAATCTTGACCTG } \\
\text { ACGAGATGTTTGGAGTCAAG }\end{array}$ & $55-60$ & 636 \\
\hline & $\mathrm{L}$ & $\begin{array}{l}\text { GRSV-L_For } \\
\text { GRSV-L_Rev }\end{array}$ & $\begin{array}{l}\text { CCATTGAGGACTGTGTAGG } \\
\text { GATGATCTACGACTGGAAG }\end{array}$ & $55-63$ & 486 \\
\hline \multirow[t]{2}{*}{ TCSV } & S & $\begin{array}{l}\text { TCSV-S_For } \\
\text { TCSV-S_Rev }\end{array}$ & $\begin{array}{l}\text { AACTGGGAAAGCAGAAAACC } \\
\text { TGCAATGTTCGGAGTAAGG }\end{array}$ & $55-65$ & 407 \\
\hline & $\mathrm{L}$ & $\begin{array}{l}\text { TCVS-L_For } \\
\text { TCSV-L_Rev }\end{array}$ & $\begin{array}{c}\text { ATGTTCGGTGGGCTGGTGTC } \\
\text { GGGAAGCATCTAGGGAAAATTATG }\end{array}$ & $55-65$ & 940 \\
\hline \multirow[t]{3}{*}{ TSWV } & S & $\begin{array}{l}\text { TSWV-S_For } \\
\text { TSWV-S_Rev }\end{array}$ & $\begin{array}{l}\text { CCCTGTGAAGAAGAAGAGATTTC } \\
\text { GATGTGCTATAATCAGGCTTTAGGC }\end{array}$ & $55-60$ & 420 \\
\hline & M & $\begin{array}{l}\text { TSWV-M2_For } \\
\text { TSWV-M2_Rev }\end{array}$ & $\begin{array}{l}\text { GGCTTTGATCTCAGAATC } \\
\text { AATCCTTGAGCATTGAC }\end{array}$ & $55-60$ & 1037 \\
\hline & $\mathrm{L}$ & $\begin{array}{l}\text { TSWV-L_For } \\
\text { TSWV-L_Rev }\end{array}$ & $\begin{array}{l}\text { CTGTTGTCTATTGAGGATTGTG } \\
\text { GTCCTGCATTAACAAGCTCTCTG }\end{array}$ & $55-65$ & 372 \\
\hline $\begin{array}{l}\text { GRSV } \\
\text { TCSV } \\
\text { TSWV }\end{array}$ & $\mathrm{L}$ & $\begin{array}{l}\text { *TospoF2L } \\
\text { *TospoR2L }\end{array}$ & $\begin{array}{l}\text { GGTTCTAACCACGACCTAGC } \\
\text { ATGATGAGTTTGAGAGGATA }\end{array}$ & 55 & 391 \\
\hline
\end{tabular}

* Primers de ampla detecção 
(a)

- Primers de ampla detecção: GRSV, TCSV e TSWV

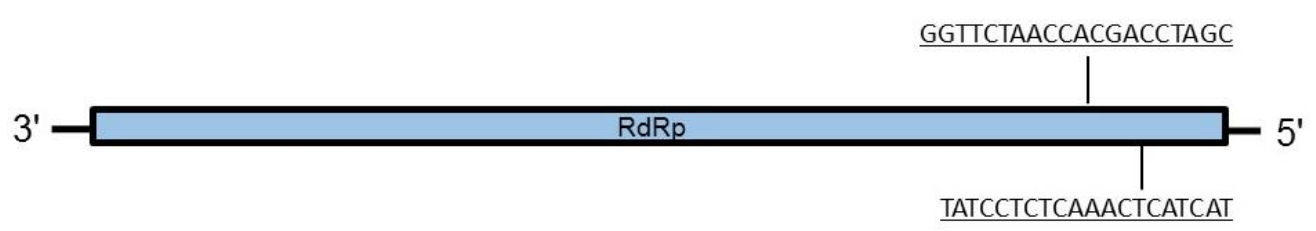

(b)

- Primers específicos: GRSV, TCSV e TSWV

RNA S (2.9 kb)

RNA M (4.8 kb)

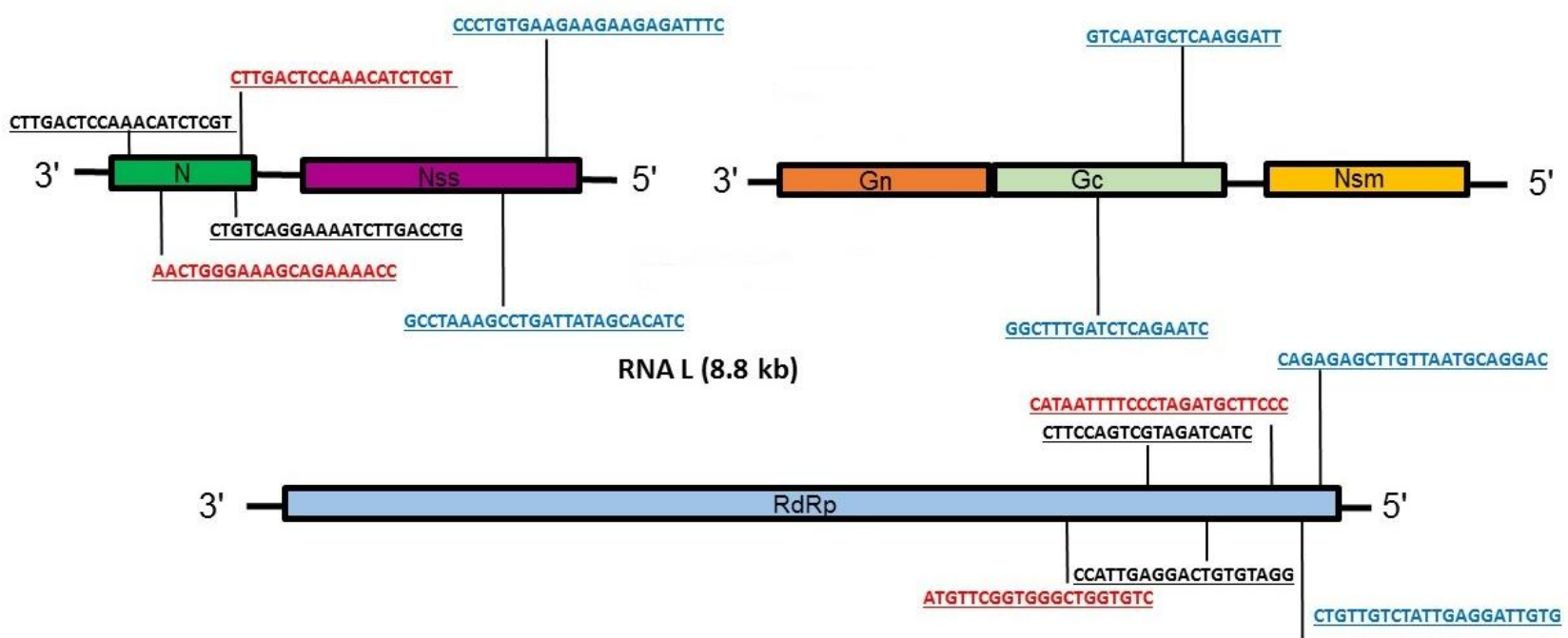

Figura 18. Representação esquemática do posicionamento dos pares de primers selecionados para detecção de Groundnut ringspot virus (GRSV), Tomato chlorotic spot virus (TCSV) e Tomato spotted wilt virus (TSWV). (a) O Par TospoF2L + TospoR2L que possui sequência homóloga ao RNA L de GRSV, TCSV e TSWV anela-se na porção terminal da ORF da polimerase (RdRp). (b) Os pares de primers para identificar os segmentos de GRSV são as sequências em preto, aqueles para amplificar os RNAs de TCSV estão escritos em vermelho e os escolhidos para detectar os segmentos de TSWV estão representados em azul claro. Os pares GRSV-S_For + GRSV-S_Rev e TCSV-S_For + TCSV-S_Rev anelam-se na ORF da proteína do nucleocapsídeo (N). TSWV-M_For + TSWV-M_Rev ligam-se à porção Gc (5') da glicoproteína. Todos os pares produzidos para identificar o RNA L das três espécies anelam-se na região 5' do segmento, GRSV-L_For + GRSV-L_Rev, TCSV-L_For + TCSV-L_Rev e TSWV-L_For + TSWV-L_Rev. O local exato de alinhamento dos primers está discriminado na Tabela 10. 


\subsection{Detecção de Tospovirus nas amostras de campo}

Neste trabalho foram realizados levantamentos de campo em algumas regiões brasileiras e na República Dominica da ocorrência de tospovírus em vários cultivos de importância econômica e em plantas silvestres, totalizando 166 amostras analizadas. Dessas, 95 foram positivas para infecção por tospovírus. Empregando-se os primers da Tabela 10 sintetizados para detecção específica dos fragmentos L, M e S de GRSV, TCSV e TSWV, nenhum rearranjo genômico (reassortants) entre as espécies de tospovírus foi detectado. Além disso, o índice de infecção mista foi de aproximadamente $7 \%$ do total de amostras infectadas. Infecções mistas foram detectadas entre GRSV e TSWV e GRSV e TCSV apenas em amostras coletadas no Brasil, ocorrendo em Solanum lycopersicum (GRSV+TSWV), Capsicum annuum (GRSV+TSWV), Datura stramonium (GRSV+TSWV) e Arachis hypogea (GRSV+TCSV). Curiosamente, a espécie TSWV só foi detectada nas amostras brasileiras em infecções mistas. TCSV foi encontrado em apenas quatro amostras brasileiras, um tomateiro e em três amostras de amendoim coletadas no estado do Goiás. A espécie mais abundante e predominate foi o GRSV presente em 100\% das amostras positivas brasileiras, repetindo o resultado observado no último levantamento realizado no final da década de 90 (Lima et al., 2000) (Tabela 11).

Na República Dominicana foi identificado TCSV em tomate (Solanum lycopersicum), pimenta doce (Capsicum annuum.), pimenta picante (Capsicum frutescens), feijão vagem (Vigna unguiculata) e no trevo comum (Trifolium sp.) coletados na província de La Vega e nas amostras de fumo (Nicotiana tabacum) da província de Santiago. Tomato spotted wilt virus (TSWV) foi encontrado em tomate (Solanum lycopersicum) e batata (Solanum tuberosum) da província de La Vega, em pimenta doce (Capsicum annuum) e na planta daninha maria-pretinha (Solanum americanum) de Monseñor Nouel, em amostras de pimenta (Capsicum spp.) e de tomate (Solanum lycopersicum) de San Jose de Ocoa (Tabela 12) (Figura 13). 
Tabela 11. Amostras sintomáticas coletadas no Brasil e analisadas via RT-PCR com primers específicos para identificação de Groundnut ringspot virus (GRSV), Tomato chlorotic spot virus (TCSV) e Tomato spotted wilt virus (TSWV)

\begin{tabular}{|c|c|c|c|c|}
\hline Estado & $\begin{array}{c}\text { Amostras } \\
\text { coletadas/infectadas }\end{array}$ & Espécie, família & Nome comum & Tospovírus \\
\hline \multirow[t]{9}{*}{ Distrito Federal } & $18 / 11$ & $\begin{array}{c}\text { Solanum lycopersicum, } \\
\text { Solanaceae }\end{array}$ & Tomate & GRSV \\
\hline & $4 / 0$ & $\begin{array}{c}\text { Nicandra physoloides, } \\
\text { Solanaceae }\end{array}$ & Joá-de-capote & \\
\hline & $5 / 2$ & Capsicum annuum, Solanaceae & Pimenta doce & $\begin{array}{c}\text { GRSV, } \\
\text { GRSV+TSWV }\end{array}$ \\
\hline & $2 / 0$ & Bidens pilosa, Asteraceae & Picão & \\
\hline & $4 / 4$ & Solanum gilo, Solanaceae & Jiló & GRSV \\
\hline & $1 / 0$ & Chenopodium sp., Solanaceae & & \\
\hline & $3 / 3$ & Datura stramonium, Solanaceae & $\begin{array}{l}\text { Figueira-do- } \\
\text { diabo }\end{array}$ & $\begin{array}{c}\text { GRSV, } \\
\text { GRSV+TSWV }\end{array}$ \\
\hline & $4 / 1$ & Capsicum sp., Solanaceae & Pimenta & GRSV \\
\hline & $1 / 0$ & Lactuca sativa, Asteraceae & Alface & \\
\hline Goiás & $57 / 27$ & $\begin{array}{c}\text { Solanum lycopersicum, } \\
\text { Solanaceae }\end{array}$ & Tomate & $\begin{array}{c}\text { GRSV, } \\
\text { GRSV+TSWV }\end{array}$ \\
\hline & $3 / 3$ & Arachis hypogaea, Fabaceae & Amendoim & GRSV+TCSV \\
\hline \multirow[t]{2}{*}{ São Paulo } & $7 / 4$ & $\begin{array}{c}\text { Solanum lycopersicum, } \\
\text { Solanaceae }\end{array}$ & Tomate & GRSV \\
\hline & $3 / 3$ & Lactuca sativa, Asteraceae & Alface & GRSV \\
\hline \multirow[t]{2}{*}{ Ceará } & $3 / 0$ & Chrysanthemum sp., Asteraceae & Crisântemo & \\
\hline & $3 / 0$ & Allium fistulosum, Alliaceae & Cebolinha & \\
\hline
\end{tabular}


Tabela 12. Amostras sintomáticas coletadas na República Dominicana e analisadas via RT-PCR com primers específicos para identificação de Groundnut ringspot virus (GRSV), Tomato chlorotic spot virus (TCSV) e Tomato spotted wilt virus (TSWV)

\begin{tabular}{|c|c|c|c|c|}
\hline Província & $\begin{array}{c}\text { Amostras } \\
\text { coletadas/infectadas }\end{array}$ & Espécie, família & Nome comum & Tospovírus \\
\hline \multirow[t]{7}{*}{ La Vega } & $6 / 4$ & $\begin{array}{c}\text { Solanum lycopersicum, } \\
\text { Solanaceae }\end{array}$ & Tomate & TSWV, TCSV \\
\hline & $4 / 4$ & Solanum tuberosum, Solanaceae & Batata & TSWV \\
\hline & $2 / 0$ & Capsicum annuum, Solanaceae & Pimenta doce & \\
\hline & $1 / 1$ & Capsicum sp., Solanaceae & Pimenta & TCSV \\
\hline & $1 / 1$ & Vigna unguiculata., Fabaceae & Feijão vagem & TCSV \\
\hline & $1 / 1$ & Capsicum frutescens, Solanaceae & Pimenta picante & TCSV \\
\hline & $1 / 1$ & Trifolium sp., Fabaceae & Trevo & TCSV \\
\hline \multirow[t]{2}{*}{ Monseñor Nouel } & $12 / 12$ & Capsicum annuum, Solanaceae & Pimenta doce & TSWV \\
\hline & $1 / 1$ & $\begin{array}{l}\text { Solanum americanum, } \\
\text { Solanaceae }\end{array}$ & Maria-Pretinha & TSWV \\
\hline \multirow[t]{3}{*}{$\begin{array}{l}\text { San Jose de } \\
\text { Ocoa }\end{array}$} & $5 / 2$ & $\begin{array}{c}\text { Solanum lycopersicum, } \\
\text { Solanaceae }\end{array}$ & Tomate & TSWV \\
\hline & $4 / 4$ & Capsicum sp., Solanaceae & Pimenta & TSWV \\
\hline & $2 / 2$ & Capsicum annuum, Solanaceae & Pimenta doce & TSWV \\
\hline Santiago & $8 / 7$ & Nicotiana tabacum, Solanaceae & Fumo & TCSV \\
\hline
\end{tabular}

O levantamento na República Dominicana revelou pela primeira vez a infecção de TSWV em batateira, tomate de mesa, pimenteira e em pimenta doce em diferentes regiões do país. Estes resultados mostraram a confirmação e expansão de TSWV em vários cultivos, e demonstrou, pela primeira vez, em campos da República Dominicana a espécie TCSV infectando feijão vagem (Vigna unguiculata), pimenta picante (Capsicum frutescens) e fumo (Nicotiana tabacum). Esses dados inéditos permitiram a publicação de uma Disease Note relatando a primeira identificação de TCSV em feijoeiro e pimenteira no país (Apêndice I). Os RNAs das amostras de feijão vagem e pimenta picante da província de La Vega foram sequenciados por NGS, com os dados ('reads') obtidos foi possível montar as sequências completas dos RNAs $\mathrm{S}$ (gb|KX463274|), M (gb|KX463273|) e L (gb|KX463272) de TCSV. Apesar de o TCSV ter sido relatado há mais de duas décadas no Brasil, as sequências completas de seus três RNAs ainda não estavam disponíveis em bancos de dados genéticos. 


\subsection{Detecção de viromas em plantas hortículas na República Dominicana}

Um amplo levantamento da presença de tospovirus foi realizado em várias áreas de produção de hortaliças na República Dominicana. Em cultivos protegidos ou em campos abertos, plantas com sintomas de vírus e suspeita de tospovírus foram testadas, como tomate (Solanum lycopersicum), pimenta doce (Capsicum annuum), pimenta picante (Capsicum frutescens), feijão vagem (Vigna unguiculata), fumo (Nicotiana tabacum) e batata (Solanum tuberosum). Os RNAs totais extraídos foram analisados via RT-PCR com primers específicos para tospovírus (Tabela 10). Além dessas primeiras detecções, um 'pool' de RNAs foram submetidos à técnica de NGS para identificação extensiva de sequências virais nessas amostras. Em ambas as amostras que foram submetidas ao sequenciamento extensivo, RD1 composta pelo 'pool' dos RNAs isolados de amostras de tomateiro, batateira, pimenteiras e feijoeiro da província de La Vega, e de pimenteiras, província de Monsenhor Nouel, e RD2 composta por um tomateiro coletado na província de San Jose de Ocoa, além dos tospovírus TCSV e TSWV detectados previamente, foram montadas sequências de espécies de vírus endógenos, ou seja, vírus que são transmitidos de forma vertical por células gaméticas (Lockhart et al., 2000; Horiuchi et al., 2004; Valverde et al., 2007).

Após o NGS, os vírus encontrados foram rastreados individualmente nos RNAs que compuseram o 'pool'. RT-PCRs com primers específicos e posterior sequenciamento desses produtos confirmaram os resultados obtidos no NGS das amostras RD1 e RD2, sendo possível determinar qual hospedeira estava infectada com os vírus encontrados (Tabela 13). Southern tomato virus (STV) (gb|KX525266|) foi encontrado infectando o tomateiro do 'pool' de amostras RD1. O STV pertence ao gênero Amalgavirus (família Amalgaviridae) e possui genoma do tipo RNA fita dupla (dsRNA), o qual codifica duas ORFs sobrepostas no genoma (Sabanadzovic et al., 2009). Um isolado do dsRNA Bell pepper endornavirus (BPEV) (gb|KX525267|) da família Endornaviridae e os dois segmentos de RNA do dsRNA Pepper cryptic virus 2 (PCV-2) (gb|KX525268| e gb|KX525269|) pertencente à família Partitiviridae foram identificados em amostras de pimenta doce da província de Monseñor Nouel (Okada et al., 2011; Sabanadzovic et al., 2011). Além disso, sequências genômicas parciais de Tobacco vein-clearing virus (TVCV) foram identificadas no tomateiro da amostra RD2 e na batateira da amostra RD1. O TVCV pertence ao gênero Solendovirus (família Caulimoviridae) e possui genoma do tipo DNA de fita dupla (dsDNA), com uma fase de RNA no ciclo replicativo (Lockart et al., 2000). Todos os vírus endógenos encontrados nas amostras submetidas ao NGS estão listados na Tabela 14. 
Tabela 13. Primers específicos sintetizados para detecção dos vírus endógenos encontrados em amostras comerciais de vegetais da República Dominicana. Temperatura de 'melting' $\mathrm{Tm}\left[{ }^{\circ} \mathrm{C}\right]$ dos primers e de anelamento na PCR

\begin{tabular}{|c|c|c|c|}
\hline Nome do primer & Sequence 5'- 3' (20nts) & $\mathrm{T}_{\mathrm{m}}\left[{ }^{\circ} \mathrm{C}\right]$ & $\begin{array}{l}\text { Temperatura de } \\
\text { anelamento }\left[{ }^{\circ} \mathrm{C}\right]\end{array}$ \\
\hline Amalga - F & TGGGTATCGACAAGCGCTAC & 60.5 & 55 \\
\hline Amalga - R & ACATGTCGAAGGCCTCCTTG & 60.5 & 55 \\
\hline Bell - F & CGCTTCGAGCATAAAAGCCC & 60.5 & 55 \\
\hline Bell - R & TGGCTTGCGCTTTTGTGTAC & 58.4 & 55 \\
\hline Pep70 - F* & CACCCGCACACAATTAACGG & 60.5 & 55 \\
\hline Pep $70-R^{*}$ & ACACATCTTCGGTCCGACAC & 60.5 & 55 \\
\hline Pep126 - F• & ACGCCCCCTATAACGCAAAA & 58.4 & 55 \\
\hline Pep126 - R・ & AATGTCGCAAGGGCCCATAA & 58.4 & 55 \\
\hline
\end{tabular}

*Primers para amplificação do RNA 1 de Pepper cryptic virus 2 (PCV-2).

- Primers para amplificação do RNA 2 de Pepper cryptic virus 2 (PCV-2).

Tabela 14. Espécies de vírus endógenos encontrados nas amostras coletadas na República Dominicana

\begin{tabular}{|c|c|c|c|c|}
\hline Vírus & Família & Hospedeiro & $\begin{array}{l}\text { Número de } \\
\text { acesso } \\
\text { GenBank } ®\end{array}$ & $\begin{array}{l}\text { Tipo do } \\
\text { genoma }\end{array}$ \\
\hline Tobacco vein-clearing virus & Caulimoviridae & Batata & & dsDNA \\
\hline Bell pepper endornavirus & Endornaviridae & $\begin{array}{c}\text { Pimenta } \\
\text { doce }\end{array}$ & KX525267 & dsRNA \\
\hline $\begin{array}{c}\text { Pepper cryptic virus } 2 \\
\text { (bipartido) }\end{array}$ & Partitiviridae & $\begin{array}{l}\text { Pimenta } \\
\text { picante }\end{array}$ & $\begin{array}{c}\text { KX525268 } \\
\text { (RNA 1) } \\
\text { KX525269 } \\
\text { (RNA 2) }\end{array}$ & dsRNA \\
\hline Southern tomato virus & Amalgaviridae & Tomato & KX525266 & dsRNA \\
\hline
\end{tabular}




\section{Discussão}

Em levantamentos da incidência de tospovírus realizados nos estados de Pernambuco, Minas Gerais, São Paulo, Paraná e Rio Grande do Sul e no Distrito Federal nos anos de 1992-1993 foi possível concluir que a distribuição das espécies de tospovírus era limitada nas regiões amostradas (Nagata et al., 1995). Foi constatada a incidência de TSWV em 85 e 95\% das amostradas avaliadas no Distrito Federal e no estado do Paraná, respectivamente. Neste estado, além de TSWV, houve também uma baixa incidência de TCSV, encontrado apenas em uma amostra, e nenhuma ocorrência de GRSV foi verificada. Nos estados de São Paulo e Rio Grande do Sul, TCSV foi encontrado em 94 e em 100\% das amostras analisadas, respectivamente. No estado de São Paulo, pôde-se detectar TSWV e outras espécies de tospovírus não conhecidas na época, mas nenhuma infecção de GRSV foi encontrada. A prevalência de GRSV ficou restrita aos estados de Minas Gerais (47\%) e em Pernambuco (67\%), contudo, a incidência foi baixa comparada àquelas observadas para TWSV no Distrito Federal e TCSV nos estados do Sul e Sudeste. Minas Gerais foi o único estado com a presença de todas as três espécies. Do total de amostras analisadas no estudo, $46 \%$ estavam infectadas com TSWV, 36\% com TCSV e apenas 8\% com GRSV (Nagata et al., 1995). No mesmo período, GRSV foi detectado em $43 \%$ das amostras de hortaliças coletadas no Submédio do São Francisco, não sendo detectado TCSV e TSWV (de Ávila et al., 1996). No último levantamento da ocorrência de GRSV e TSWV em áreas hortícolas do Nordeste e no Distrito Federal, no período de 1995-1997, GRSV foi detectado em mais de $70 \%$ das amostras de pimentão infectadas com tospovírus e em $67 \%$ das amostras de tomateiro (Lima et al., 2000). Groundnut ringspot virus (GRSV) foi reportado com baixa incidência no Espírito Santo (4\%), onde plantas de tomate e pimentão com fortes sintomas de virose foram avaliadas quanto à presença de vírus dos gêneros Tospovirus, Potyvirus e Cucumovirus. Nesta ocasião, mais de 50\% das amostras analisadas estavam infectadas com Pepper yellow mosaic virus (PepYMV) (de Ávila et al., 2004). Neste trabalho de tese, GRSV foi detectado em 100\% das amostras infectadas com tospovírus coletadas nos estados de São Paulo, Ceará, Goiás e no Distrito Federal. Tal resultado demonstra que GRSV continua a ser a espécie de Tospovirus mais abundante em regiões hortícolas do Centro-Oeste e Nordeste e vem expandindo sua população em regiões do Sudeste, onde a incidência de TSWV está claramente diminuindo.

Depois do último levantamento das espécies de tospovírus TSWV e GRSV feito no Brasil, era possível que atualmente a espécie mais abundante pudesse ser outra 
diferente de GRSV, pois a prevalência de espécies virais no campo muitas vezes é cíclica, como já foi observado, por exemplo, para begomoviroses (Lima et al., 2000; Ribeiro, 2006; Raush et al., 2008). Contudo, o que foi observado até o momento é que a incidência de TSWV apresentou um declínio acentuado em regiões produtoras de hortaliças do Distrito Federal, já que no último levantamento sua ocorrência foi relatada em pelo menos $30 \%$ das amostras analisadas e há um crescimento da incidência de GRSV na região Centro-Oeste (Lima et al., 2000; Nagata et al., 2004). As razões da prevalência de GRSV no campo provavelmente estão relacionadas à interação vírusvetor. As mesmas espécies de tripes que transmitem TSWV no Brasil, também transmitem GRSV, Frankliniella occidentalis e Frankliniella shultzei (Nagata et al., 2004; Rlley et al., 2011). No entanto, a eficiência de transmissão das espécies de tospovírus pelas espécies de tripes é variável. F. occidentalis relatado no país a partir da década de 1990 em estados do Nordeste (Alagoas e Pernambuco), Sudeste (São Paulo e Rio de Janeiro) e Sul (Rio Grande do Sul e Santa Catarina) apresentou eficiência de pouco mais de $70 \%$ e $17 \%$ na transmissão de TSWV e GRSV, respectivamente. Enquanto que $F$. shultzei com relato no país anterior ao de $F$. occidentalis e encontrado nas regiões Nordeste (Bahia, Maranhão, Pernambuco e Rio Grande do Norte), CentroOeste (Goiás e Mato Grosso do Sul), Sudeste (São Paulo) e Sul (Paraná e Rio Grande do Sul) teve eficiência de $93 \%$ e pouco mais de $12 \%$ na transmissão de GRSV e TSWV, respectivamente (Monteiro et al., 2001; Nagata et al., 2004) (Figura 19). 


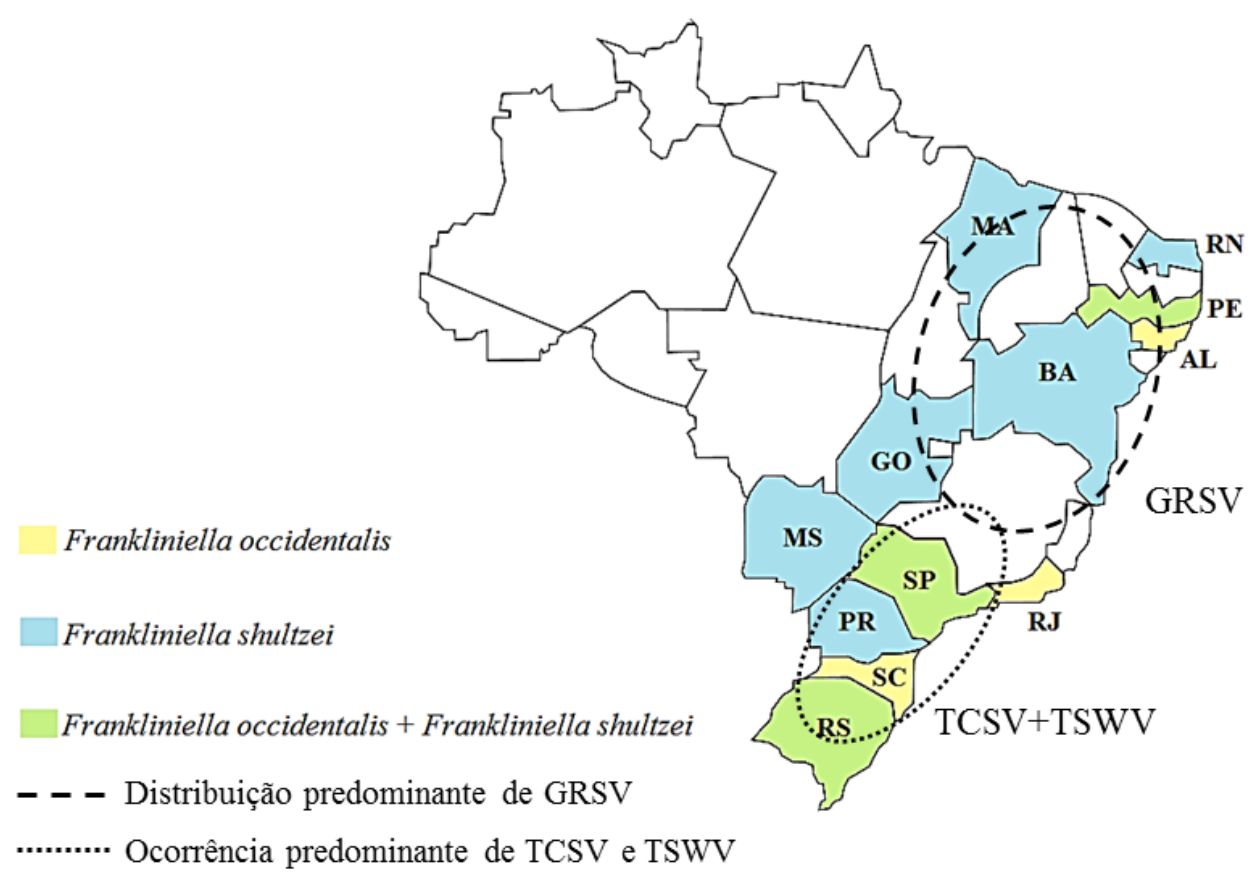

Figura 19. Relação dos estados brasileiros onde foram relatadas as espécies de tripes Frankliniella occidentalis e Frankliniella. shultzei. O Groundnut ringspot virus (GRSV) ocorre com mais frequência em regiões hortícolas do Nordeste e Centro-Oeste, onde F. shultzei é predominante. Tomato chlorotic spot virus (TCSV) e Tomato spotted wilt virus (TSWV) são mais comuns nos estados do Sul e Sudeste, onde a ocorrência de F. occidentalis é maior do que F. shultzei. Fonte: Lima et al., 2000; Monteiro et al., 2001; Nagata et al., 2004.

TCSV foi descrito pela primeira vez infectando tomateiros no Brasil no início da década de 1990 (de Ávila et al., 1990; de Ávila et al., 1993a). Até pouco tempo atrás, a ocorrência de TCSV estava restrita a províncias na Argentina e a poucos estados no Brasil, sem representar impedimento para a produção agrícola (Dewey et al., 1997; Nagata et al., 1995; de Ávila et al., 1996; Lima et al., 2000; Eiras et al., 2012). No entanto, nos últimos 4 anos novos relatos de infecções severas causadas por TCSV têm ocorrido em países do Caribe (República Dominicana, Costa Rica e Haiti) e em estados do sul e sudeste dos Estados Unidos (Webster et al., 2010; Londoño et al., 2012; Webster et al., 2013; Batuman et al., 2015; Webster et al., 2015; Adegbola et al., 2016). A situação que se apresenta na República Dominicana em relação à disseminação de tospovirus, pode se tornar um bom modelo para hipóteses de especiação no gênero, em contraste com regiões de maior equilíbrio populacional, já que o Caribe têm sido um 'hotspot' de novos isolados de tospovírus.

Devido à ausência de rearranjo (reassortant) entre espécies de tospovírus nas amostras coletadas no Brasil, um ambiente considerado de equilíbrio na prevalência de espécies de tospovírus, e na República Dominicana, ambiente em adaptação com a 
emergência de novas espécies, questiona-se se o isolado híbrido ( $\mathrm{S}_{\mathrm{GRSV}} \mathrm{M}_{\mathrm{TCSV}} \mathrm{L}_{\mathrm{GRSV}}$ ), relatado nos Estados Unidos (Webster et al., 2011) seja realmente um isolado proveniente de um rearranjo ocorrido recentemente. Um dos principais fatores que influencia na disseminação viral e a interação das espécies de vírus e seus vetores. $\mathrm{Na}$ tentativa de elucidar a pressão biológica que levou à formação do possível isolado híbrido, testes com os principais vetores de tospovírus foram realizados e não foi encontrada diferença significativa na transmissão do isolado $S_{\text {GRSV }} M_{\text {TCSVL }} L_{G R S V}$ em relação aos isolados parentais de GRSV e TCSV (Webster et al., 2015). Além disso, os RNAs M de GRSV e TCSV não se separam filogeneticamente como duas espécies independentes, como observado para as outras ORFs que se agrupam em clados espécie-específicos. Estes resultados sugerem que os RNAs M de GRSV e TCSV são originados de um ancestral comum às duas espécies (Breuil et al., 2016).

Infecções mistas entre vírus de plantas já foram relatadas em diferentes tipos de interação. Muitas doenças virais são causadas pela coinfecção de múltiplos isolados de uma mesma espécie, como a tristeza do citrus que é o resultado da infecção de estirpes claramente separadas filogeneticamente de Citrus tristeza virus (CTV) (Harper et al., 2015). Este tipo de interação também pode ocorrer entre espécies de grupos taxonômicos distintos. Como exemplo, podemos citar o padrão de infecções múltiplas observado em plantas de alho, as quais são infectadas concomitantemente por espécies dos gêneros Potyvirus, Allexivirus e Carlavirus (Fayad-Andre et al., 2011; Mituti et al., 2014). Infecções mistas também são comuns entre espécies pertencentes a um mesmo gênero, sendo essa associação, causadora de doenças em importantes culturas, como o complexo de espécies de Begomovirus responsável pela 'Cotton leaf curl disease' em algodoeiro (Briddon et al., 2003). No gênero Tospovirus são relatadas infecções causadas por estirpes da espécie TSWV, o que pode ser considerado como um tipo de infecção mista, a qual é sugerida como um fator que favorece a evolução da espécie (Tentchev et al., 2011; Margaria et al., 2015).

A associação dos vírus de plantas em infecção múltipla pode resultar em interações ecológicas ainda não caracterizadas entre os indivíduos, possibilitando a permanência no ambiente (Fargette et al., 2006; Harper et al., 2015). A combinação de vírus na mesma planta pode causar reações muito mais severas ou atenuar a expressão de sintomas, mascarando a infecção viral e aumentando a permanência da planta no campo. Devido à necessidade de aprofundar nos estudos de vírus de plantas, principalmente aqueles que são negligenciados por não causarem sintomas aparentes, a metagenômica tem sido amplamente utilizada e o sequenciamento extensivo tornou-se 
uma importante ferramenta no diagnóstico de doenças virais e descoberta de novos vírus (Sela et al., 2012; Mitter et al., 2013; Prabha et al., 2013; Chandler et al., 2014).

O sequenciamento do 'pool' (RD1) de amostras de tomateiro, batateira, pimenteiras e feijoeiro, na província de La Vega, de pimenteiras na província de Monsenhor Nouel, e do tomateiro de San Jose de Ocoa da amostra RD2, além dos tospovírus TCSV e TSWV, revelou a presença de Tobacco vein clearing virus (TVCV), Southern tomato virus (STV), Pepper cryptic virus 2 (PCV) e Bell pepper endornavirus (BPEV). Todos são vírus endógenos, ou seja, são encontrados no citoplasma ou no núcleo da célula e são replicados a cada divisão celular, sendo transmitidos de forma vertical por células gaméticas, dispensando a presença de um vetor no ciclo de vida (Lockhart et al., 2000; Horiuchi et al., 2004; Valverde et al., 2007). Os vírus endógenos não matam o hospedeiro e os danos fisiológicos à planta muitas vezes são brandos, sem sintomas expressivos (Staginnus et al., 2009). Vírus que são capazes de estabelecer tão estreita relação com a célula, na qual estão inseridos, e infectam de forma persistente o hospedeiro, ou seja, eles permanecem na planta hospedeira indefinidamente (Roossinck et al., 2011).

Bell pepper endornavirus (família: Endornaviridae) (BPEV) (gb|KX525267|) encontrado em Capsicum annuum já havia sido relatado infectando diversas espécies e tipos de Capsicum spp. (Okada et al., 2011). Ainda foram detectados o Southern tomato virus (STV) (família: Amalgaviridae) (gb|KX525266|) em tomateiro, como também, sequências parciais de Tobacco vein clearing virus (TVCV) (família: Caulimoviridae) em batateira os dois segmentos de RNA de Pepper cryptic virus 2 (PCV) (família: Partitiviridae) (gb|KX525268| e gb|KX525269|) em pimenta-doce (Capsicum annuum) de Monseñor Nouel. A amostra RD2 composta apenas por um tomateiro da província de San José de Ocoa estava infectada com TVCV, além do TSWV. O vírus TVCV além de endógeno é também um pararetrovírus, ou seja, partes do genoma viral são incorporadas ao DNA do hospedeiro. Os pararetrovírus compõem a família Caulimoviridae e são vírus de DNA de fita dupla (dsDNA) semicirculares ou lineares que utilizam de uma forma intermediária de RNA para replicação (Lockart et al., 2000; Gregor et al., 2004). Os membros das famílias Amalgaviridae, Endornaviridae e Partitiviridae são vírus de RNA fita dupla (dsRNA) lineares. (Boccardo et al., 1987; King et al., 2012). O TVCV e as sequências similares foram encontradas em cromossomos de tomateiro (Solanum lycopersicum), pimenteiras (Capsicum spp.), batateira (Solanum tuberosum), diversos tipos de fumo (Nicotiana spp.), petúnia (Petunia spp.), bananeira (Musa spp.) (Boccardo et al., 1987; Lockhart, 
1986; Richert-Pöggeler et al., 1997; Haper et al., 2002; Hansen et al., 2005; Valverde et al., 2007; Sabanadzovic et al., 2009).

Os contigs montados de Tobaco vein-clearing virus (TVCV) nas amostras de tomateiro e batateira a partir de RNA viral indicam que genes desse vírus foram expressos nessas plantas que também estavam infectadas com TSWV. Tomato spotted wilt virus (TSWV) também foi encontrado em Capsicum annuum com infecção persistente de Bell pepper endornavirus (BPEV) (Endornaviridae) e Pepper cryptic virus 2 (PVC-2). A razão da existência de sequências virais incorporadas ao genoma das plantas pode ser para atuar em vias de silenciamento gênico pós-transicional por meio de RNA interferente (RNAi), no entanto, essa hipótese ainda não foi bem elucidada. Além disso, essas sequências exógenas foram encontradas flanqueando outros genes, o que sugere que elas podem influenciar na expressão gênica dos genes da hospedeira (Matzke et al., 2000).

Apesar de a incidência de infecções mistas observadas entre espécies de tospovírus ter sido baixa, os resultados das poucas amostras analisadas por NGS demonstram que a presença de mais de uma espécie em infecções virais é a regra e não a exceção. O significado biológico dessas interações necessita ser elucidado. 


\section{Apêndice I}

The First Report of Tomato chlorotic spot virus (TCSV) infecting long beans and chilli peppers in Dominican Republic. Plant Disease 98(9):1285 doi.org/10.1094/PDIS-04-14-0348-PDN

M. M. S. Almeida ${ }^{1}$, A. F. Orílio ${ }^{1}$, F. L. Melo ${ }^{1}$, R. Rodriguez $^{2}$, A. Feliz $^{3}$, X. Cayetano ${ }^{3}$, R. T. Martínez ${ }^{3}$, R. O. Resende ${ }^{1}$

${ }^{1}$ Dept. de Biologia Celular, Universidade de Brasília, Brasília, Brasil

${ }^{2}$ Ministerio de Agricultura, Departamento de Sanidad Vegetal, Santo Domingo, Dominican Republic.

${ }^{3}$ Instituto Dominicano de Investigaciones agropecuarias y forestales - IDIAF, Ensanche Evaristo Morales, Santo Domingo, Dominican Republic

The Dominican Republic has a significant area of the country cultivated with vegetables. In July 2013, in the provinces of Moca and La Vega, horticultural crops showed typical tospovirus symptoms (> 30\% incidence), including bronzing, chlorosis, necrosis and ring spots on leaves and fruits. Samples were collected from potatoes (Solanum tuberosum), long beans (Vignaun guiculata), chilli peppers (Capsicum frutescens), sweet peppers (Capsicum annuиm) and tomatoes (Solanum lycopersicum). Serological tests were clearly positive for infection by Tomato spotted wilt virus (TSWV) and/or related tospoviruses when tested with AgDia immunostrips. The viral RNA extracted from 5 plants per host was pooled to construct a cDNA library that was sequenced using an Illumina HiSeq 2000 (Illumina) platform. The paired-end reads were assembled using CLC genomic Workbench version 6.0.3. The assembled contigs were submitted to blastx against a viral genome database. The results confirmed the presence of Tomato chlorotic spot virus (TCSV) and TSWV. Then, PCR tests were performed with primers pairs TSWV-LF 5' CTG TTG TCT ATT GAG GAT TGT G 3' \& TSWV-LR 5' CAG AGA GCT TGT TAA TGC AGG AC 3' to amplify part of the TSWV L RNA, the pairs TCSV-SF 5'AAC TGG GAA AGC AGA AAA CC 3' \& TCSV-SR 5' CCT TAC TCC GAA CAT TGC A 3' and GRSV-SF 5' CTG TCA GGA AAA TCT TGA CCT G 3’ \& GRSV-SR 5’ CTT GAC TCC AAA CAT CTC GT 3’ to detect part of the TCSV and Groundnut ringspot virus (GRSV) S segments. In the long bean and chilli pepper samples from La Vega, only TCSV was detected (40\% of the all 
samples) based on amplification of the expected size fragment with the S RNA specific primer pair. All the other samples were positive for TSWV and no GRSV was detected. The complete $\mathrm{N}$ gene of TCSV and TSWV were amplified using the primer pairs TCSV-NR2 5' CACACTGAACTGAACTATAACACAC 3’ \& TCSV-NF 5’ ACC TTG AAT CAT ATC TCT CG 3’and primers N-TSWV_FW 5’ TAC GGA TCC GAT GTC TAA GGT TAA GCT CAC 3’ \& N-TSWV_RV 5’ TTA TCT CGA GTC AAG CAA GTT CTG CGA G 3'. The TCSV N protein sequences (KJ399303 and KJ399304) were 99\% identical with the TCSV found in processing tomatoes in DO (1) and in the USA (2). The TSWV N protein sequences (KJ399313, KJ399314 and KJ399315) shared 98\%-96\% identity with the TSWV N sequences available. In addition, no reassortants were detected based on amplification of the expected size RNA fragments. These other amplicons (KJ399301, KJ399299, KJ399302 and KJ399300) showed 98\% identity with the $\mathrm{L}$ and $\mathrm{M}$ segments of TCSV. Thrips collected from symptomatic plants were identified mainly as Frankliniella schultzei, consistent with the main thrips species transmitting TCSV. In the last two years, TCSV was reported in North and Central America and in the Caribbean Basin (1, 2, 3). These findings have an important epidemiological impact and can be used to guide seed companies and growers. It could change the cultivars of sweet pepper and chilli pepper cultivated in these regions since, the $T s w$ resistance gene used to confer resistance to tospovirus is specific to TSWV but it is not effective against the TCSV species (4). In addition, TCSV represents a new threat to other horticultural crops affected by this tospovirus.

(1) O. Batuman et al. Plant Disease, 98:286, 2014 (2) A. Londono et al.Tropical Plant Pathology. 37:333, 2012 (3) Webster, C. G. et al. 2013. First Report of Tomato chlorotic spot virus (TCSV) in Tomato, Pepper, and Jimsonweed in Puerto Rico. Plant Health Progress. Online publication. doi:10.1094/PHP-2013-0812-01-BR (4) Lovato et al. Virus Research, 137:245-252, 2008. 


\section{CAPÍTULO 2: Filogeografia Iris yellow spot virus (IYSV), Tomato chlorotic spot virus (TCSV) e Tomato spotted wilt virus (TSWV)}

\section{Introdução}

O comércio global de material vegetal, sementes, flores, frutos expandiu muito a partir de 1960 (Kiritani, 2001), favorecendo à dispersão, tanto de vírus, quanto de insetos vetores. Dentre esses patógenos, os tospovírus e os tripes vetores podem ser considerados um dos principais gêneros que apresentam uma dispersão mundial. Decifrar as rotas e tendências globais de espalhamento dos tospovírus é uma necessidade econômica, pois possibilita a formulação de métodos quarentenários mais eficientes, assim como, a adoção de medidas preventivas para minimizar a dispersão de espécies de tospovírus entre as diversas regiões geográficas do mundo.

Baseado em análises filogenéticas, o gênero Tospovirus é comumente separado em dois clados: americano e euroasiático, os quais representam dois centros de diversificação de espécies, provavelmente, a partir de um ancestral comum. No clado americano estão as espécies filogeneticamente mais relacionadas à Tomato spotted wilt virus (TSWV), enquanto que, no clado euroasiático, agrupam-se as espécies mais próximas à Watermelon silver mottle virus (WSMoV) espécie descrita pela primeira vez em melância em Taiwan e que representa um tospovírus filogeneticamente distinto do TSWV (Shyi-Dong et al., 1992; Silva et al., 2001; Wei-Te et al., 2014).

IYSV foi descrito pela primeira vez no início da década de 1980 em cebolas no Brasil como doença "tipo-tospovírus", mas de acordo com sua filogenia é uma espécie classificada no clado euroasiático, próxima à espécie européia Polygonum ringspot virus (PolRSV), à espécie Tomato yellow ring virus (TYRV) isolada no Iran e Hippeastrum chlorotic ringspot virus, isolada na China (HCRV) (Figura 10) (de Ávila et al, 1981; Bag et al., 2015). IYSV foi caracterizado como nova espécie por Cortês e colaboradores na Holanda em 1998 e a partir daí atingiu grande relevância nos Estados Unidos, onde causa perdas na produção de cebola (Nischwitz et al., 2007), além de estar disseminado em algumas regiões da América do Sul, como no Peru. O exemplo da espécie IYSV demonstra claramente a introdução e adaptação de um vírus a regiões geográficas distintas, provavelmente, devido ao fluxo de material vegetal contaminado.

TSWV é uma espécie disseminada mundialmente, podendo ser encontrada nos cinco continentes. TSWV é conhecido por infectar mais de 900 espécies de plantas, distribuídas em mais de 90 famílias de monocotiledôneas e dicotiledôneas. TSWV foi descrito pela primeira vez na Austrália em 1915, contudo, devido à falta de diversidade 
dos isolados australianos e o fato de se agruparem filogeneticamente com os isolados europeus, provavelmente o TSWV foi introduzido no país devido à colonização européia. O que reforçou essa hipótese é o fato de no início do século $\mathrm{XX}$ a prática agrícola não era comum no país e plantas nativas eram raramente encontradas infectadas por TSWV (Costa et al., 1941; Dietzgen et al., 2005; Pappu et al., 2009). No início da década de 1990, o eficiente vetor de TSWV Frankliniella occidentalis foi introduzido na Austrália e, como em outras partes do mundo, essa ocorrência resultou em surtos epidêmicos de TSWV, o que tornou essa espécie de tospovírus o principal foco de pesquisas e estudos em doenças de plantas no país (Latham et al., 1996; Latham et al., 1997).

TCSV tem se destacado no cenário global de disseminação de tospovírus devido às recentes epidemias que vêm causando em países da região do Caribe e nos Estados Unidos em importantes culturas hortículas (Webster et al., 2010; Webster et al., 2013; Almeida et al., 2014; Batuman et al., 2015; Webster et al., 2015; Adegbola et al., 2016). Estes locais ainda não haviam relatado a presença dessa espécie, a qual era restrita à América do Sul, ocorrendo na Argentina e no Brasil, porém, com pouco destaque. Além disso, a observação de TCSV nesses países era principalmente restrita à plantas ornamentais, apesar de ter sido relatado pela primeira vez infectando tomateiros no Brasil (Dewey et al., 1997; Nagata et al., 1995; de Ávila et al., 1996; Lima et al., 2000; Eiras et al., 2012). Recentemente, TCSV foi relatado em tomateiros, pimenteiras, feijoeiro, no fumo, amendoim, alface e em diversas espécies de plantas-daninhas (Webster et al., 2010; Webster et al., 2013; Almeida et al., 2014; Batuman et al., 2015; Webster et al., 2015; Adegbola et al., 2016).

$\mathrm{Na}$ história genealógica de todos os seres vivos é possível detectar os fatores que levaram à evolução e adaptação das espécies. Vários fatores são considerados importantes por atuarem como fatores evolutivos, como mutações, derivas genéticas, fluxos gênicos e a seleção natural, eventos demográficos, como colonização ou extinção de populações locais, expansão ou declínio populacional e migração, fatores esses que deixam marcas no genoma dos organismos. A observação e os estudos desses eventos possibilitam a compreensão da história evolutiva das espécies. A filogeografia surgiu com a necessidade de se incorporar, tanto os dados das relações genéticas dos indivíduos, quanto suas ocorrências geográficas (Avise et al., 1987; Cunha et al., 2012). Dessa forma, essa abordagem visa estudar os princípios e processos, históricos e contemporâneos, que influenciaram a distribuição geográfica das linhagens genealógicas dentro de uma espécie ou entre espécies próximas (Avise et al., 1987). 
Neste trabalho, reconstruções filogeográficas de TSWV, TCSV e IYSV foram realizadas. Estas espécies foram escolhidas porque TSWV é a espécie tipo do gênero, IYSV que de acordo com sua filogenia é uma espécie classificada no clado euroasiático, mas apresenta distribuição mundial, e o TCSV que foi descrito no início dos anos 90 juntamente com GRSV, como restrito à América do Sul, mas desde 2010, vem se disseminando para outras regiões geográficas do continente americano (de Ávila et al., 1990; Pappu et al., 2009; Webster et al., 2010; Londoño et al., 2012; Webster et al., 2013; Almeida et al., 2014; Batuman et al., 2015; Webster et al., 2015; Adegbola et al., 2016).

\section{Metodologia}

Sequências de nucleotídeos do RNA $\mathrm{S}$ correspondentes à proteína do nucleocapsídeo $(\mathrm{N})$ foram adquiridas no abrangente banco de dados genético GenBank® (http://www.ncbi.nlm.nih.gov) para compor o 'dataset' necessário nas análises de filogeografia, juntamente com amostras sequenciadas nesse trabalho de tese. Sequências de diferentes regiões geográficas do mundo, isoladas de hospedeiros variados foram utilizadas com o propósito de se observar padrões de distribuição dos tospovírus IYSV, TCSV e TSWV.

As análises filogenéticas e de filogeografia foram realizadas apenas com sequências que possuem informações completas sobre data e local de coleta. Cento e onze isolados de IYSV coletados em vinte e nove países, vinte e oito sequências de TCSV de cinco países e cento e vinte e um isolados de TSWV identificados em trinta países foram utilizados nas análises. As amostras foram agrupadas de acordo com a macrorregião geográfica em que o país de coleta está inserido (Tabela 15).

Os alinhamentos múltiplos das sequências selecionadas foram realizados com o programa MUSCLE, sendo em seguida estimado por meio do programa JmodelTest versão 2.1.4 o modelo filogenético que melhor se adapta à história evolutiva dos isolados analisados (Darriba et al., 2012). As análises filogenéticas foram feitas pelo software PhyML, ambos por meio da multiplataforma SeaView v.4.5.4 (Edgar, 2004; Guindon et al., 2009; Gouy et al., 2010). As árvores filogenéticas construídas a partir dos modelos selecionados foram submetidas à análises do programa PATH-O-GENE versão 1.4 para verificar a regressão linear entre a distância genética da raiz com a data de coleta de cada sequência dos isolados. Depois de verificada à correlação entre a raiz e as datas de coletas dos isolados, extensivas análises de filogeografia do RNA S (proteína $\mathrm{N}$ ) foram realizadas por meio do programa BEAST v.1.6.2. Nesta etapa, 
diversos parâmetros evolucionários foram testados para a análise de cada espécie, sendo os mais satisfatórios utilizados para construir a melhor árvore. A inspeção das relações entre as probabilidades posteriores e os parâmetros evolucionários relevantes, foram verificadas pelo programa TRACER versão 1.5. As árvores geradas nas análises baesianas foram sumarizadas em uma mais parcimoniosa utilizando o programa TreeAnnotator v.1.6.2 e a reconstrução ancestral foi visualizada no programa FigTree v.1.3.1 (Figura 21 e Figura 22) (Drummond et al., 2012). Os dados gerados nas análises baesianas de filogeografia foram plotados em um mapa para visualização das rotas de distribuição global das espécies IYSV, TCSV e TSWV. Estas análises foram realizadas por meio do programa SPREAD (Spacial Phylogeography Reconstruction and EvolucionAry Dynamics) e visualizadas pelo programa Google Earth. As rotas de espalhamento dos vírus estudados foram depois associadas ao fluxo de importação e exportação de importantes culturas suscetíveis a essas espécies de tospovírus nos países envolvidos (Figura 23). 
Tabela 15. Países e macrorregiões em que os isolados de Iris yellow spot virus (IYSV), Tomato chlorotic spot virus (TCSV) e Tomato spotted wilt virus (TSWV) utilizados nas análises de filogeografia foram coletados

\begin{tabular}{|c|c|c|}
\hline Tospovírus & País & Macrorregião \\
\hline \multirow[t]{30}{*}{ IYSV } & Estados Unidos da América & América do Norte \\
\hline & Canadá & \\
\hline & Peru & América do Sul \\
\hline & Brasil & \\
\hline & Chile & \\
\hline & Uruguai & \\
\hline & México & América Central \\
\hline & Guatemala & \\
\hline & Bósnia e Herzegovina & Sul da Europa \\
\hline & Sérvia & \\
\hline & Itália & \\
\hline & Espanha & \\
\hline & Grécia & \\
\hline & Reino Unido & Europa Central \\
\hline & Alemanha & \\
\hline & Holanda & \\
\hline & África do Sul & África \\
\hline & Maurício & \\
\hline & Quênia & \\
\hline & Tajiquistão & Ásia Central \\
\hline & Japão & Ásia Oriental \\
\hline & Paquistão & Sudeste Asiático \\
\hline & Sri Lanka & \\
\hline & India & \\
\hline & Israel & Sudoeste Asiático \\
\hline & Irã & \\
\hline & Austrália & Oceania \\
\hline & Nova Zelândia & \\
\hline & Brasil & América do Sul \\
\hline & Argentina & \\
\hline \multirow[t]{17}{*}{ TCSV } & Estados Unidos da América & América do Norte \\
\hline & Porto Rico & América Central \\
\hline & República Dominicana & \\
\hline & Estados Unidos da América & América do Norte \\
\hline & Brasil & América do Sul \\
\hline & Argentina & \\
\hline & Venezuela & \\
\hline & República Dominicana & América Central \\
\hline & Polônia & Europa Central \\
\hline & França & \\
\hline & Alemanha & \\
\hline & Hungria & \\
\hline & Holanda & \\
\hline & Montenegro & Sul da Europa \\
\hline & Itália & \\
\hline & Sérvia & \\
\hline & Bulgária & \\
\hline \multirow[t]{15}{*}{ TSWV } & Espanha & \\
\hline & Zimbabwe & África \\
\hline & África do Sul & \\
\hline & Quênia & \\
\hline & Coréia do Sul & Ásia Oriental \\
\hline & China & \\
\hline & Japão & \\
\hline & Taiwan & \\
\hline & India & Sudeste Asiático \\
\hline & Turkia & Sudoeste Asiática \\
\hline & Síria & \\
\hline & Líbano & \\
\hline & Jordânia & \\
\hline & Austrália & Oceania \\
\hline & Nova Zelândia & \\
\hline
\end{tabular}




\section{Resultados}

As análises das reconstruções filogenéticas permitiram identificar que as migrações de IYSV e TCSV foram intensas nos anos de 1980 e 1990, enquanto que o deslocamento de TSWV começou nas primeiras décadas do século XX, progredindo entre os anos de 1960 e 1990 (Figura 20; Figura 21).

Inicialmente, os principais centros de distribuição de TSWV para o mundo foram os Estados Unidos, os países asiáticos Japão e China e a Austrália. A filogeografia dos isolados de TSWV revelou que estes estão agrupados por localidade geográfica, sinalizando que as populações de TSWV atingiram certa estabilidade genética e estão adaptadas aos nichos ecológicos em que se encontram. Além disso, os longos braços observados na filogeografia de TSWV e os elevados valores de probabilidade posterior demonstram a presença de diversidade genética, pois quanto menos variabilidade na sequência, mais difícil determinar a composição do clados. Dessa forma, muitas vezes, os valores de probabilidade posterior são baixos porque não há informação suficiente para garantir o grau de relacionamento filogenético (Figura 20). Diferentemente, os isolados de IYSV flutuam entre os grupamentos geográficos formados. Tal mobilidade demonstra que a ocupação e permanência das populações de IYSV ainda não estão estabelecidas nas áreas produtoras. As rotas de migração de TSWV e IYSV são semelhantes e ocorreram por toda região tropical e subtropical (Figura 22). O IYSV tem origem europeia, de onde se espalhou por todos os continentes do velho mundo e, em seguida, para o continente americano. Na América, o principal centro de distribuição da espécie foram os Estados Unidos, de onde alcançou a América do Sul e Central (Figura 20).

TCSV possui uma história recente de dispersão da América do Sul, precisamente do Brasil, local de origem, para outras regiões do continente americano. A linhagem brasileira se espalhou pelo país, migrou para a América do Norte, chegando, em seguida, à América Central, na região do Caribe (Figura 21). A recente introdução na América do Norte é associada à provável causa do aparecimento de uma nova composição viral, o primeiro isolado rearranjado intra-espécies de Tospovirus. Este novo isolado é caracterizado por possui o $\mathrm{S}$ e o L RNAs de GRSV e o M RNA de

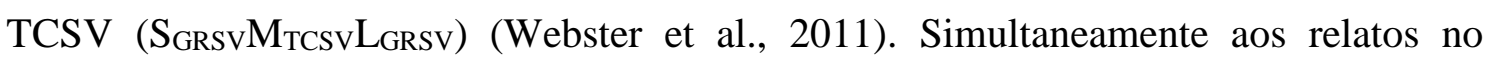
estado da Flórida (USA), o TCSV foi relatado em países da América Central. Os isolados originados com a introdução na América do Norte são mais relacionados filogenéticamente com os isolados do Caribe, compartilhando, pelo menos, 97\% de identidade de nucleotídeos no gene da nucleopretína $(\mathrm{N})$. 
(a)

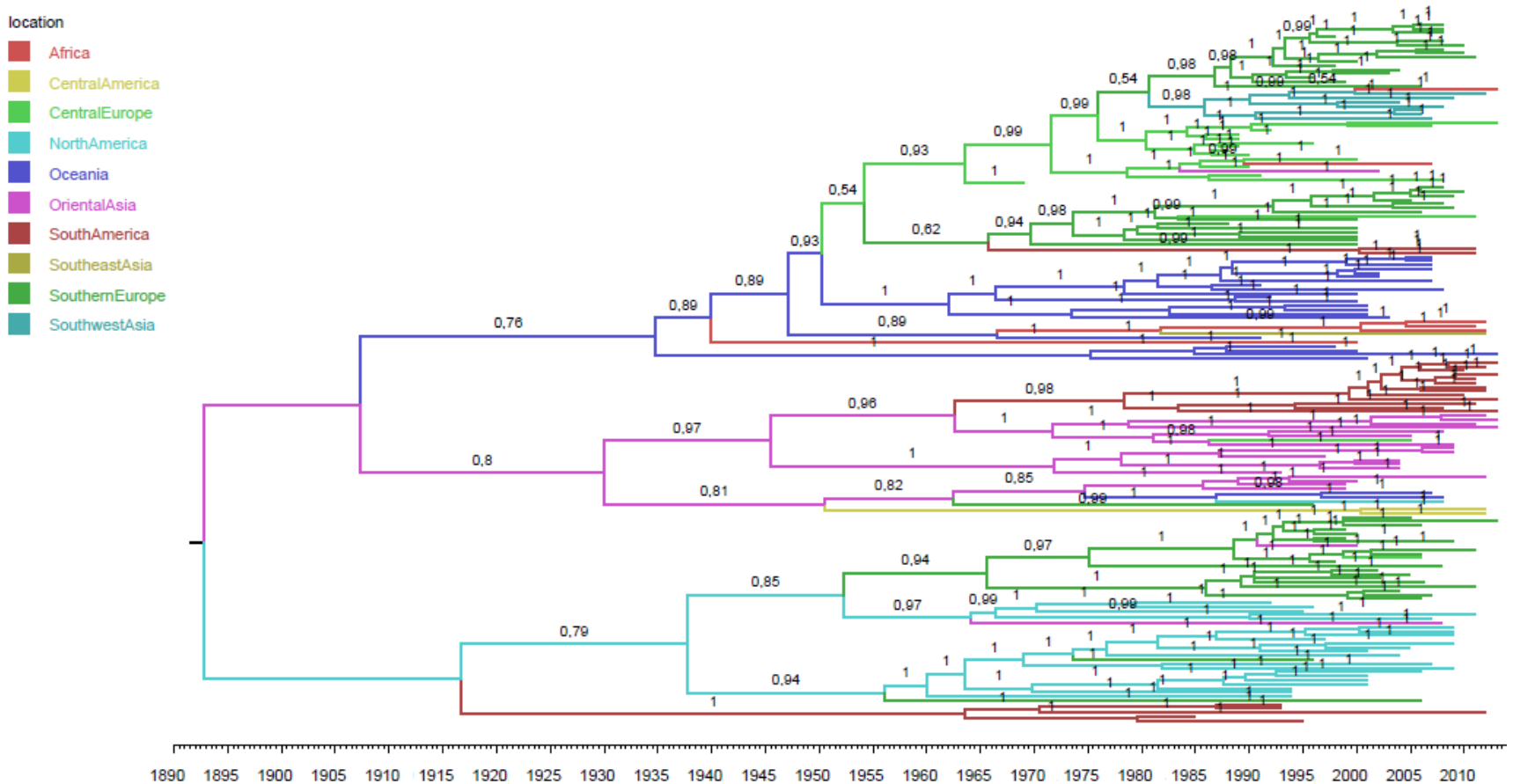

(b)
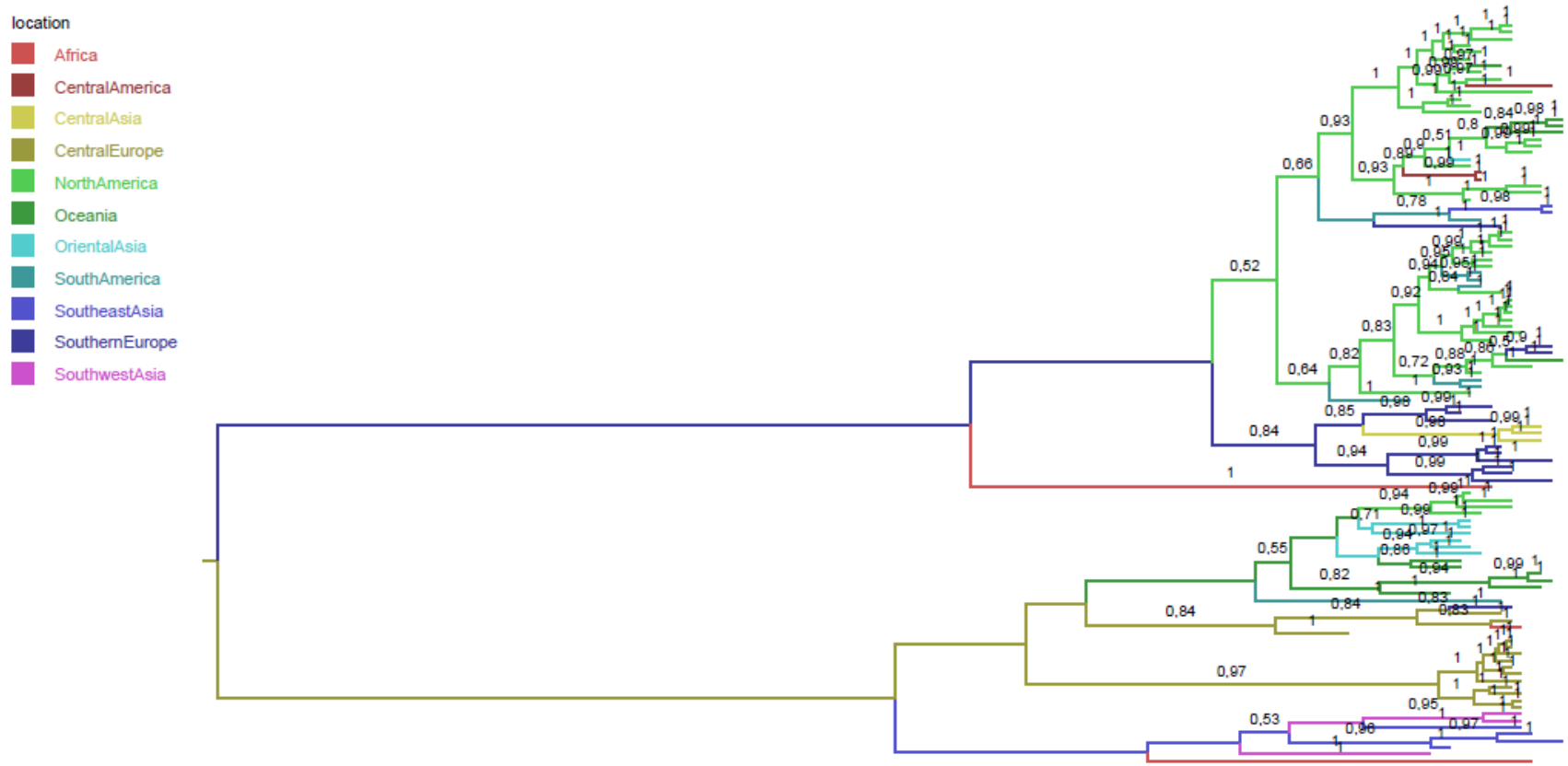

Figura 20. Filogeografia de Tomato spotted wilt virus (TSWV) e Iris yellow spot virus (IYSV). O TSWV (painel A) pode ter origem asiática ou americana, enquanto que o IYSV (painel B) foi originado em países asiáticos. Ambos se espalharam para o resto do globo. Os valores de probabilidade relacionados à localidade estão sinalizados nos braços dos clados, sendo representados valores acima de $50 \%$ ou 0,5 . 


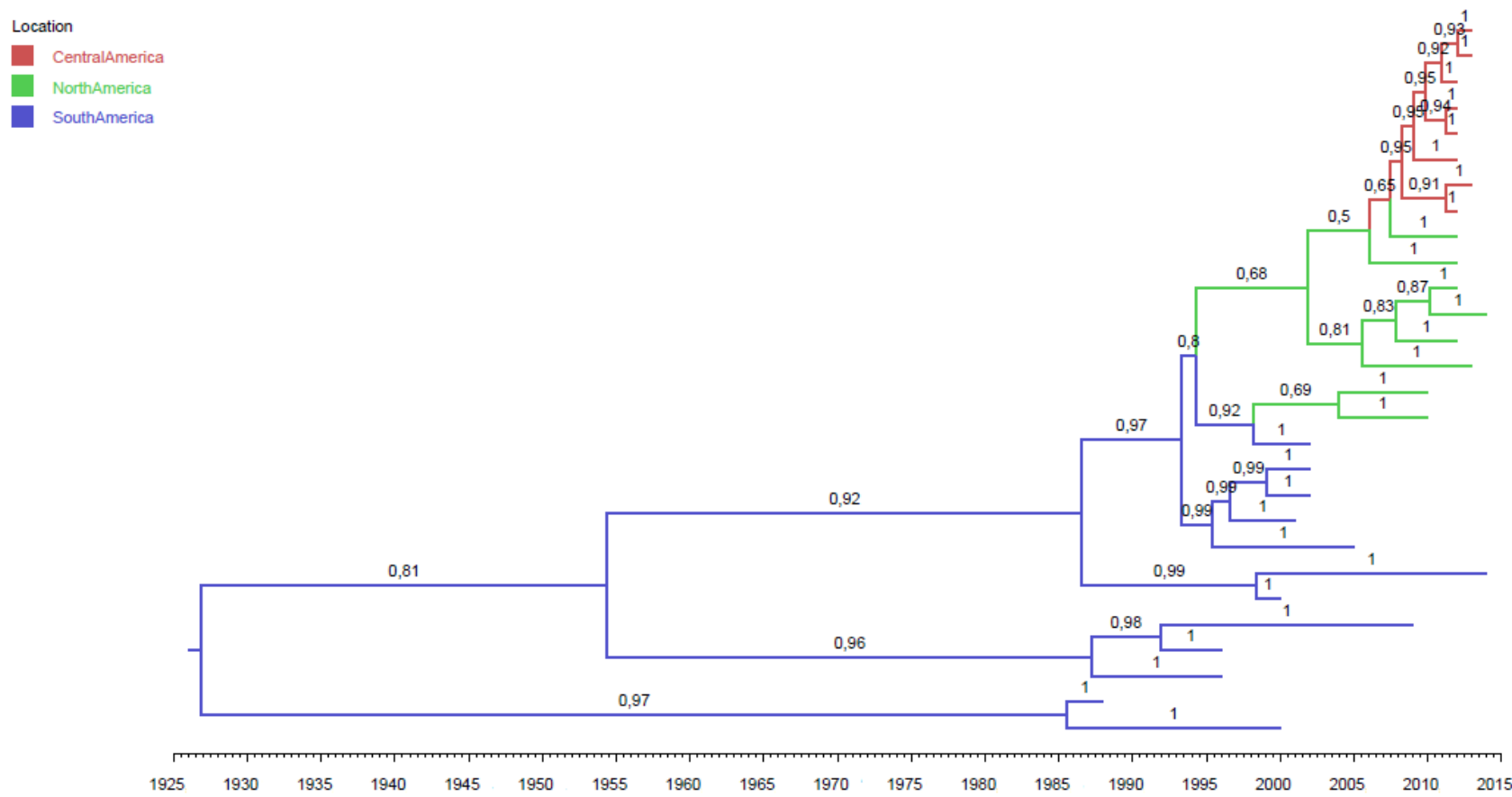

Figura 21. A filogeografia de Tomato chlorotic spot virus (TCSV) mostra que esse vírus é originário do continente americano com duas prováveis linhagens ancestrais, uma brasileira e outra argentina. A linhagem brasileira espalhou-se por todo o país, chegando à América do Norte e ao Caribe, propiciando, posteriormente, um fluxo constante de material viral entre essas regiões. Os valores de probabilidade relacionados à localidade estão sinalizados nos braços dos clados, sendo representados valores acima de $50 \%$ ou 0,5 .

\section{Discussão}

A demanda por produtos agrícolas tem crescido desde os anos de 1960, atingindo execelentes metas na década de 1970. Nos anos de 1980, a produção mundial de muitos produtos alimentícios sofreu grande queda, no entanto, foi um período em que foi registrado aumento significativo da produção de vegetais, gorduras e óleos vegetais e frutas tropicais. Crescimento que se manteve na década seguinte, aumentando o fluxo de mercadorias entre os países (FAO, 1999). Os anos de 1980 também foram marcantes pela intensa disseminação dos tripes vetores, destacando a espécie Frankliniella occidentalis capaz de transmitir GRSV, TCSV e TWSV com eficiência variável (Kiritani et al., 2002; Kirk et al., 2003; Pappu et al., 2009) (Tabela 6). Apesar de possuírem fatores similares na sua dispersão, a dinâmica de deslocamento viral foi distinta para cada tospovírus analisado (Figura 23). 

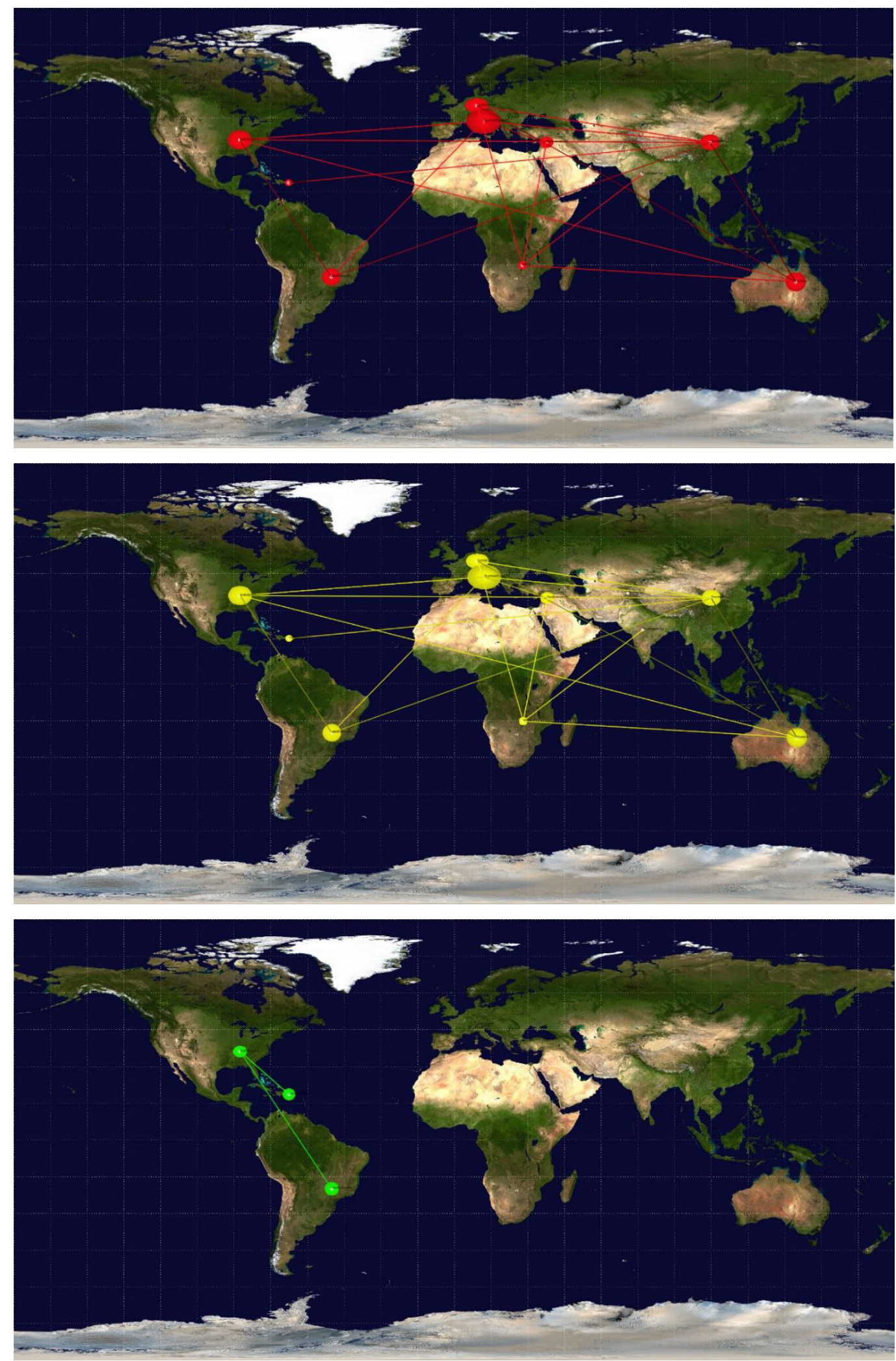

Figura 23. Perfil de distribuição global, baseado na filogeografia, de Tomato spotted wilt virus (TSWV) (vermelho), Iris yellow spot virus (IYSV) (amarelo) e Tomato chlorotic spot virus (TCSV) (verde) gerado no programa SPREAD. A intensidade de coloração e o raio dos círculos são determinados de acordo com o número de linhagens que compartilham o mesmo estado ancestral. 
Atualmente, nos Estados Unidos (EUA), TSWV permanece circulando dentro do país, sem escapes para outras localidades, além disso, todas as sequências norte americanas possuem, provavelmente, um mesmo ancestral, a partir de uma única introdução. Essa falta de trânsito dos isolados norte americanos para o resto do mundo e vice-versa, pode se dar pelo fato de que a maior parte do tomate produzido nos EUA é utilizado no consumo interno, com menos de $2 \%$ destinado à exportação (FAO, 2013). Além disso, apenas uma pequena porcentagem de pimentas e pimentões consumidos no país são importados de outras localidades (México e Canadá), sendo a grande maioria produzida internamente (USITC, 2007). Assim, essa prática econômica parece limitar o fluxo de mercadorias e de material contaminado com TSWV para outras regiões no mundo. O IYSV apresenta-se com mais mobilidade do que as outras espécies de tospovírus comparadas nesse trabalho. Isto pode ser explicado pelo fato de que, os EUA importam cebolas de países como o Canadá, Japão, México e Peru e exportam para o Japão e Canadá, assim, a rede de compartilhamento desse produto é diversificada (FAO, 2013).

Na Europa, a migração de TSWV é maior entre países do centro e sul da Europa, como entre França e Itália, e Espanha e França. O livre comércio entre países membros da zona do euro intensificado a partir de 1986 destinou quase 70\% das exportações e importações desses países a parceiros da União Européia (Diniz et al., 2013). É possível descrever as rotas de migração de IYSV concentradas em apenas dois países, EUA e Japão, com um fluxo viral no qual os EUA recebem e enviam a maior parte dos isolados caracterizados. Já para o TSWV, o intercâmbio ocorre basicamente entre os países da Europa, como há também um fluxo dos países europeus para a Ásia (Figura 24).

A delimitação de isolados à uma região geográfica também foi observada em estudos de filogeografia com espécies pertencentes aos gêneros Potyvirus, Begomovirus e Sobemovirus (Abubakar et al., 2003; Venkataravanappa et al., 2011; Cuevas et al., 2012). Estudos com Rice yellow mottle virus (RYMV) na África, gênero Sobemovirus, demonstraram que a diversidade genética dos isolados analisados estava diretamente relacionada com a distribuição geográfica dos mesmos. Ainda, nas topologias das árvores filogenéticas construídas no trabalho, isolados de uma mesma grande região geográfica, como por exemplo, isolados do oeste africano, foram separados em clados de acordo com o bioma onde foram coletados, selva ou savana. Além disso, nestes estudos não foi possível identificar evidências de que isolados são disseminados à longas distâncias, pois quanto maior o isolamento geográfico, maior a variabilidade genética observada (Abubakar et al., 2003). A segregação geográfica de isolados virais 
também foi observada em estudos com beta satélites em plantas de quiabo (Abelmoschus esculentus). Beta satélites são pequenas moléculas de DNA circular que estão associadas ao DNA genômico de espécies do gênero Begomovirus. Estas moléculas foram caracterizadas a pouco mais de dez anos e pouco se sabe sobre sua interação com as espécies relatadas (Venkataravanappa et al., 2011). A filogeografia do potyvírus Potato virus $Y$ (PVY) também revelou a relação do local de coleta na diversidade dos isolados, ainda, demonstrou que, assim como a distribuição geográfica, o hospedeiro exerce grande influência na adaptação dos isolados ao habitat (Cuevas et al., 2012).

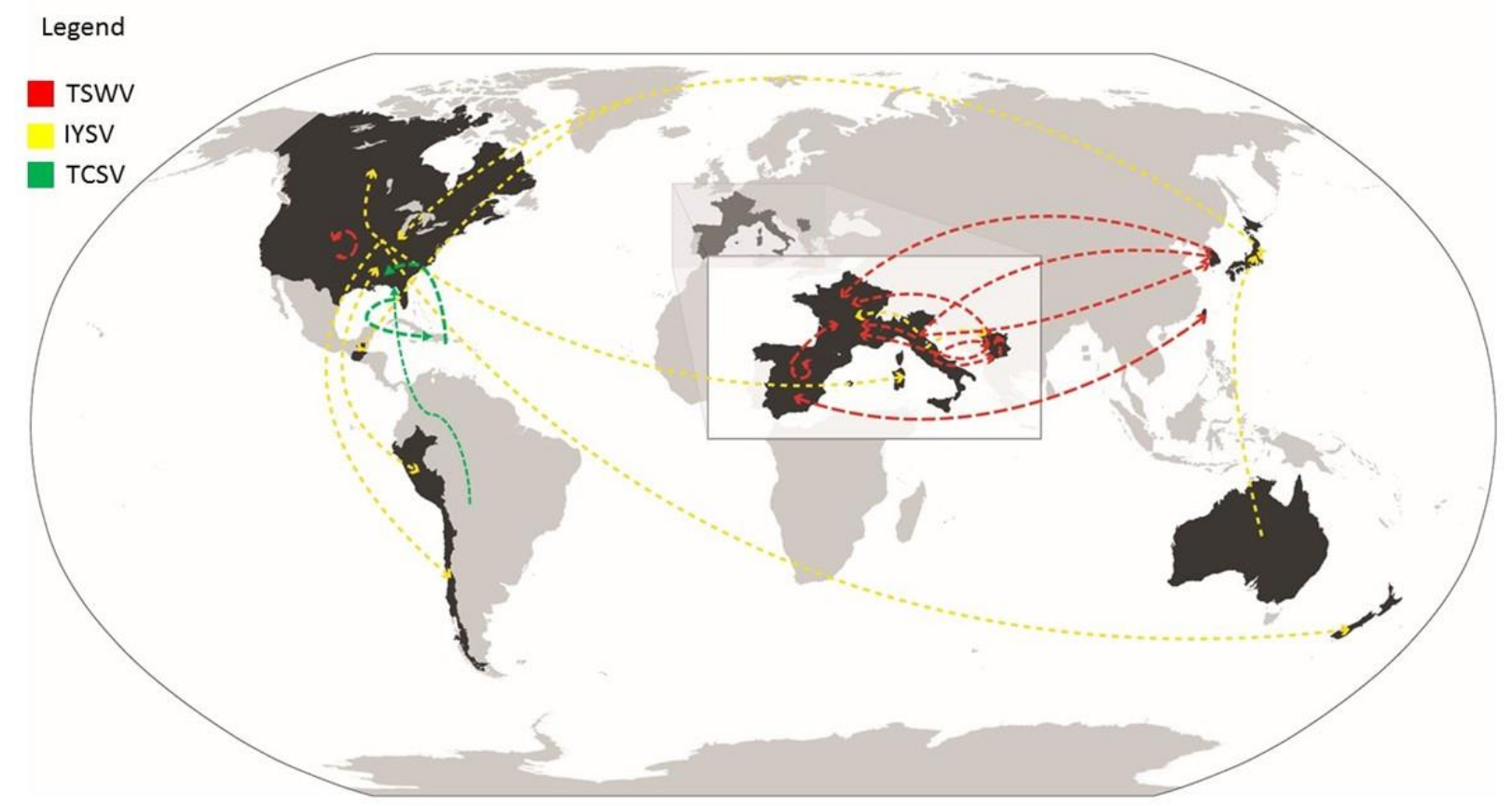

Figura 24. Espalhamento mundial de Tomato spotted wilt virus (TSWV), Iris yellow spot virus (IYSV) e Tomato chlorotic spot virus (TCSV), baseado na diversidade viral e no fluxo internacional de produtos agrícolas. O fluxo mais intenso de TSWV ocorre basicamente dentro dos Estados Unidos e entre os países da zona do euro com os países asiáticos. Da mesma forma, o espalhamento de TCSV hoje está restrito ao sul e leste dos Estados Unidos com os países da região do Caribe. Diferentemente o IYSV, apresenta uma distribuição global, com fluxo de material genético ocorrendo em quase todos os continentes.

O papel do hospedeiro no desenvolvimento das espécies virais pode ser evidenciado quando sequências de RNA viral podem ser encontradas frequentemente no transcriptoma dos hospedeiros (Staginnus et al., 2007; Li et al., 2015). Como hospedeiros consideram-se plantas e insetos, que também são vetores. Além disso, 
espécies virais com pouca relação filogenética foram encontradas infectando as mesmas espécies de artrópodes, situações similares podem ser observadas com as plantas, onde infecções mistas com espécies virais não relacionadas são recorrentes (Fargette et al., 2006; Li et al., 2015). Isto sugere que o hospedeiro desempenha papel relevante na evolução dos vírus. Além disso, muitas vezes as plantas carregam sequências completas de vírus endógenos que se mantêm indeterminadamente nas células hospedeiras (Lockhart, 1986; Richert-Pöggeler et al., 1997; Harper et al., 2002; Hansen et al., 2005; Valverde et al., 2007; Sabanadzovic et al., 2009; Khankhum et al., 2015).

A proteína não estrutural NSs codificada pelo RNA $\mathrm{S}$ dos tospovírus é fequentemente apontada como responsável pela quebra de resistência e adaptação de tospovirus às plantas hospedeiras. Esta proteína acumula mais mutações positivas do que as outras proteínas e apresenta grande variabilidade entre os diferentes isolados (Tentchev et al. 2011). Assim, como a dispersão de isolados está associada à localização geográfica, mas não existem evidências de que esses se deslocam por grandes distâncias, provavelmente, os isolados de tospovírus se adaptam rapidamente ao ambiente no qual foram introduzidos por meio de mutações sofridas na proteína NSs. Os fatores que realmente determinam a dispersão e evolução das espécies virais ainda são desconhecidos. Pelas observações disponíveis nesse tipo de estudo, os vírus parecem chegar em um local novo e depois se diferenciam, adaptando-se ao novo nicho ecológico. Espécies e isolados modificam-se, provavelmente devido à hospedeira a qual estão infectando.

O próprio ambiente pode favorecer a permanência de alguma espécie, como no caso da utilização de genes de resistência, dependendo do gene introduzido nas plantas, há o favorecimento de determinada espécie. Como exemplo podemos mencionar a ampla utilização dos genes $\mathrm{S} w-5$ e $T s w$ em tomateiro e pimenteira, respectivamente, visando a obtenção de resistência a tospovirus nessas hortaliças. Na República Dominicana, cultivares de pimenta-doce resistentes à TSWV com o gene $T s w$ são utilizadas largamente, o que pode ter favorecido à expansão de TCSV, para o qual, o gene Tsw não é eficiente. A alta disseminação e capacidade infectiva de TCSV nesse país, provavelmente possibilitou a contaminação de diferentes tipos de cultivos hortículas. Plantas que ainda não tinham sido relatadas como hospedeiras de TCSV foram encontradas com sintomas típicos e severos de tospovírus, sendo confirmado a presença de TCSV por PCR e sequenciamento genético. Variedades de fumo (Nicotiana tabacum) que dificilmente eram encontradas abrigando tospovírus, foram acometidas por um surto de infecção causada por TCSV no país, assim como, variedades de 
feijoeiro (Almeida et al., 2014). Dessa forma, a adaptação eficiente dos vírus a novos ambientes ecológicos, pode representar uma ameaça importante ao cultivo de diversas culturas economicamente relevantes para os países produtores.

As análises de dispersão das espécies de tospovírus IYSV, TCSV e TSWV revelaram que IYSV e TCSV estão em expansão, principalmente o TCSV. Este vírus tem se disseminado com muita agressividade no sul e sudeste dos Estados Unidos e em países da região do Caribe. No entanto, ressalta-se que, os Estados Unidos não são grandes exportadores de produtos agrícolas como o tomate, pimentões e pimentas, o que dificulta a dispersão de TCSV para outros continentes por esse país. Portanto, outros fatores de dispersão devem estar envolvidos, como provavelmente, a movimentação de populações de tripes infectados entre essas regiões por diferentes meios. Por outro lado, na República Dominicana as principais mercadorias exportadas são as pimentas picantes (Capsicum frutescens) e outras variedade de Capsicum spp. (FAO, 2013). Portanto, a República Dominicana e os países do Caribe tem grandes chances de se tornarem os principais centros de dispersão de TCSV para o velho mundo, onde ainda não há relatos dessa espécie. Outra constação desse estudo indica que o TSWV parece estar se tornando restrito a certas regiões e sua disseminação foi significativamente diminida, apesar das novas coletas realizadas não terem sido extensivas como descrito no capítulo 1. No levantamento restrito realizado, não foi possível resgatar tantos isolados de TSWV como em estudos realizados no passado.

Estudar como os vírus se evoluem ajuda os cientistas a entender o que faz com que certos vírus consigam se dispesar com eficiência no ambiente. Dessa forma, pode-se melhorar os métodos quarentenários adotados e aperfeiçoar os programas de melhoramento genético visando a incorporação de resistência à vírus. Contudo, para realização dessas análises é necessário possuir informações completas das coletas de isolados virais. O que limita o processamento, análise e conclusão dos dados é a dificuldade em se obter todas as informações relevantes para o conjunto de variáveis a serem analisadas.

Assim, predizer o deslocamento viral, associando essa informação às políticas econômicas dos países ou estados, pode prevenir surtos e epidemias virais, preservando o que é mais importante: a sanidade e a qualidade do produto agrícola. 


\section{CAPÍTULO 3: Determinação do 'fitness' entre Groundnut ringspot virus (GRSV) e Tomato chlorotic spot virus (TCSV) e estudo da ancestralidade dos RNAs M de TCSV e GRSV}

\section{Introdução}

Tomato chlorotic spot virus (TCSV) e Groundnut ringspot virus (GRSV) são classificados no serogrupo II, porém, em serotipos diferentes, apresentam relação filogenética próxima ( $81 \%$ de identidade na sequência de aminoácidos da proteína $\mathrm{N}$ ). Ambos foram descritos infectando tomateiro no Brasil no início da década de 90 com os isolados BR-3 (TCSV) e SA-5 (GRSV) (de Ávila et al., 1990; de Ávila et al., 1993a) (Tabela 1). Inicialmente, TCSV e GRSV mantiveram nichos geográficos restritos a poucos estados brasileiros, contudo, GRSV se disseminou para diversos outros estados, tornando-se a espécie de tospovírus mais disseminada no Brasil na atualidade. O TCSV, por sua vez, apresentava uma distribuição ainda restrita à algumas regiões brasileiras (Nagata et al., 1995; de Ávila et al., 1996; Lima et al., 2000; Eiras et al., 2012). No entanto, nos últimos quatro anos, relatos de infecções severas causadas por TCSV têm ocorrido em países do Caribe (República Dominicana, Haiti e Costa Rica e em estados do sul e sudeste dos Estados Unidos, onde GRSV também é relatado. (Webster et al., 2010; Londoño et al., 2012; Webster et al., 2013; Batuman et al., 2015; Webster et al., 2015; Adegbola et al., 2016). Esta crescente disseminação de TCSV na América do Norte levou os cientistas a aprofundarem os estudos em relação a esta espécie, o que possibilitou a descrição de um provável isolado híbrido (rearranjo) entre espécies de tospovírus, o qual foi descrito como possuindo os segmentos $\mathrm{S}$ e L de GRSV e o segmento M de TCSV (S $\mathrm{S}_{\mathrm{GRSV}} \mathrm{M}_{\mathrm{TCSV}} \mathrm{L}_{\mathrm{GRSV}}$ ) (Webster et al., 2011).

Os tospovírus podem interagir de maneira intra e interespecíficas, podendo, portanto, infectar novos hospedeiros. Margaria e colaboradores (2015) observaram que genomas tripartidos tem potencial para trocar segmentos genômicos inteiros entre diferente isolados em uma infecção mista, dessa forma, relataram o surgimento de novas variantes de TSWV capazes de infectar plantas pimenteiras contendo o gene $T s w$ de resistência a tospovirus. Estudos anteriores mostraram que o rearranjo ocorre espontaneamente em TSWV (Qiu et al., 1999; Tentchev et al., 2011). Isolados rearranjados naturalmente de TSWV foram amplamente coletados na Espanha, França e Itália, mostrando que esse mecanismo desenvolve um papel importante na emergência e na epidemia da espécie. Além disso, trocas de fragmentos genômicos inteiros foram 
observadas entre populações europeias e asiáticas de tospovirus (Tentchev et al., 2011; Lian et al., 2013). A proteína não-estrutural NSs codificada pelo RNA S foi identificada como o principal fator para superar o gene de resistência Tsw em pimenta. Entre isolados rearranjados capazes de quebrar a resistência conferida pelo gene $T s w$, nenhum segmento de tipo S selvagem foi detectado, sinalizando que este fragmento é alvo de mutações (Margaria et al., 2007).

Dois fatores principais são responsáveis pela resistência genética adquirida. São eles: a capacidade de acumular mutação e de que forma essas mutações irão afetar a interação vírus-hospedeiro. Em um amplo estudo com isolados europeus, pôde-se observar que a proteína NSs é alvo de muitas substituições positivas, ou seja, que não levam à troca do aminoácido. Isso sugere que há uma facilidade na aquisição das propriedades que possibilitam a quebra de resistência. Ademais, pode-se notar que as mutações não são dispendiosas para o fitness do vírus, já que estiveram sob seleção positiva, assim, a competitividade com os parentais em plantas experimentais comuns não é um problema para os isolados rearranjados (Tentchev et al., 2011). Observou-se que em uma co-infecção entre dois tospovírus distintos TSWV e Iris yellow spot virus (IYSV), a proteína NSs de IYSV pôde ser detectada em folhas sistêmicas da hospedeira não suscetível Datura stramonium, devido à interação com TSWV (Sudeep et al., 2012), sugerindo uma complementação de funções gênicas entre as duas espécies virais durante o processo infectivo.

A troca de segmentos genômicos inteiros entre espécies e isolados de tospovírus é uma ferramenta evolutiva (Tentchev et al., 2011; Webster et al., 2011; Lian et al., 2013). Contudo, a regulação de tal mecanismo no nível de espécie parece ser mais restrita do que entre isolados (Tentchev et al., 2011; Lian et al., 2013;). De acordo com os métodos de detecção utilizados atualmente, infecções mistas entre espécies de tospovírus são relatadas com pouca frequência, o que dificulta a detecção acurada da ocorrência natural de rearranjos entre as espécies do gênero. O isolado detectado nos Estados Unidos ( $\mathrm{S}_{\mathrm{GRSV}} \mathrm{M}_{\mathrm{TCSV}} \mathrm{L}_{\mathrm{GRSV}}$ ) possui competitividade no campo, pois os levantamentos realizados indicam que este isolado está se disseminando pelas áreas agrícolas produtoras de tomate, pimentas e pimentões (Webster et al., 2015). O principal critério taxônomico para classificar espécies no gênero Tospovirus determina que as sequências de aminoácidos da proteína $\mathrm{N}$ de isolados classificados numa mesma espécie, possuam pelo menos $90 \%$ de identidade entre si (King et al., 2012). A sequência de aminoácidos da proteína $\mathrm{N}$ se tornou o principal critério taxômico de 
classificação dos tospovírus porque essa proteína esta envolvida em importantes processos regulatórios como na transcrição, encapsidação e replicação do RNA genômico (de Ávila et al., 1993a). Além disso, a proteína N possui grande variabilidade genética entre as espécies e isolados de Tospovirus (Tentchev et al., 2011). Em média, a identidade nucleotídica dos RNAs S de isolados de GRSV e TCSV oscila entre 79-88\% e a identidade dos RNAs L é ligeiramente superior a $80 \%$, enquanto que os RNAs M dessas espécies possuem $95 \%$ de identidade. Esses nívies de identidade suscitam o questionamento sobre a existência de rearranjos naturais entre essas duas espécies de tospovírus, fomentando, dessa forma, estudos mais aprofundados sobre a estreita relação entre as espécies GRSV e TCSV.

Atualmente, os estudos sobre evolução no gênero Tospovirus são escasos e concentrados na espécie-tipo TSWV. Visando contribuir com os estudos de evolução, o estreito parentesco entre GRSV e TCSV foi analisado por filogenia e a interação dessas espécies na infecção mista foi observada em planta hospedeira experimental de Nicotiana benthamiana. A capacidade de infectar o hospedeiro, obtendo sucesso competitivo é conhecida como o 'fitness' viral. O 'fitness' de GRSV e TCSV foi associado ao número de moléculas do gene da proteína do nucleocapsídeo $(\mathrm{N})$ presentes no RNA total extraído de plantas com infecção mista (GRSV+TCSV). A diversidade de sequências de nucleotídeos entre os segmentos genômicos foi analizada e os estudos de evolução foram concentrados no RNA M de GRSV e TCSV, buscando elucidar a ancentralidade desse segmento e o seu envolvimento no processo de formação de rearranjos naturais interespecíficos no gênero Tospovirus.

\section{Metodologia}

\subsection{Ensaio biológico: infecção mista e análise de 'fitness' de Groundnut ringspot virus (GRSV) e Tomato chlorotic spot virus (TCSV)}

Os primeiros isolados de GRSV (isolado SA-05) e TCSV (isolado BR-3) caracterizados no mundo e mantidos em folhas de Nicotiana benthamiana congeladas à $-80^{\circ} \mathrm{C}$ na Universidade de Wageningen (WUR), Países Baixos, foram inoculados separadamente em plantas de $N$. benthamiana para recuperação da capacidade infectiva dos vírus mantidos congelados por muitos anos. Após o aparecimento dos primeiros sintomas, as folhas dessas plantas sistemicamente infectadas foram utilizadas na preparação de três inóculos distintos (Figura 25). Os inóculos foram preparados com 
porções do extrato foliar das plantas infectadas com TCSV e com GRSV, com o propósito de homogeneizar as concentrações virais e criar um ambiente competitivo para as duas espécies e, assim, observar as capacidades de infecção nas condições estabelecidas.

O tecido infectado com vírus foi macerado em solução tampão de fosfato de sódio $0.01 \mathrm{M}(\mathrm{pH}$ 7) e o extrato foliar obtido foi friccionado com abrasivo nas plantas experimentais (Nicotiana benthamiana) (de Avila et al. 1993). Três tipos de inóculos foram preparados simultaneamente utilizando diferentes concentrações dos extratos foliares iniciais: um composto de uma parte (1x) TCSV e 10 partes (10x) GRSV, o outro com uma parte (1x) TCSV e uma parte (1x) GRSV e o último com dez partes (10x) TCSV e uma parte (1x) GRSV. As concentrações iniciais dos inóculos foram determinadas por ELISA direto utilizando anticorpos específicos para cada um dos vírus. A infecção viral foi acompanhada diariamente, com base no desenvolvimento de sintomas locais e sistêmicos. A presença viral foi confirmada com primers específicos por meio de RT-PCR convencional e a acumulação viral, que reflete o "fitness" de cada vírus, foi medida por RT-PCR em tempo real (qRT-PCR) com primers específicos para detecção da proteína do nucleocapsídeo (N) de TCSV e GRSV nas folhas apicais sistemicamente infectadas (Tabela 16). Dessa forma, três tratamentos foram comparados utilizando-se treze plantas de $N$. benthamiana inoculadas por tratamento. 
(a)

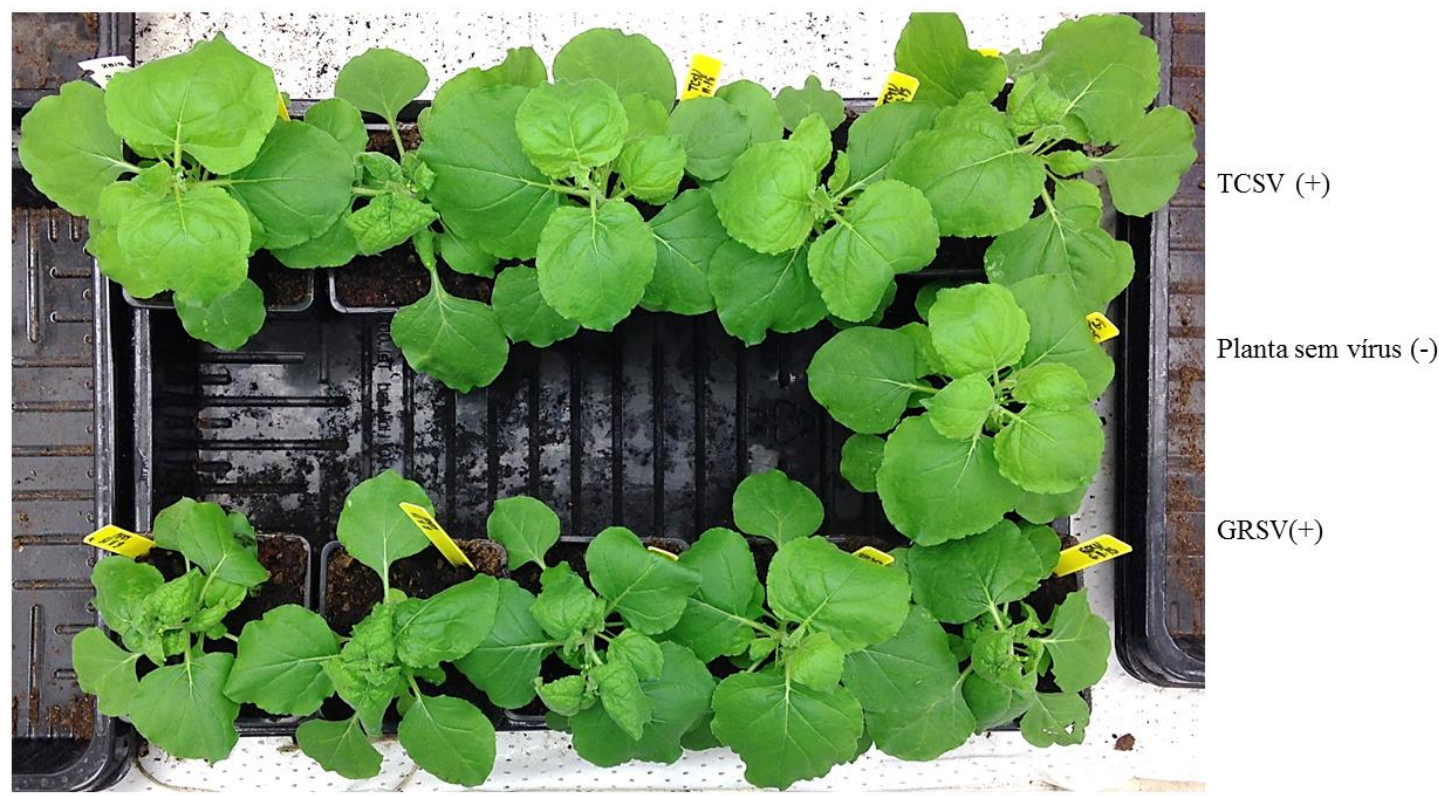

(b)

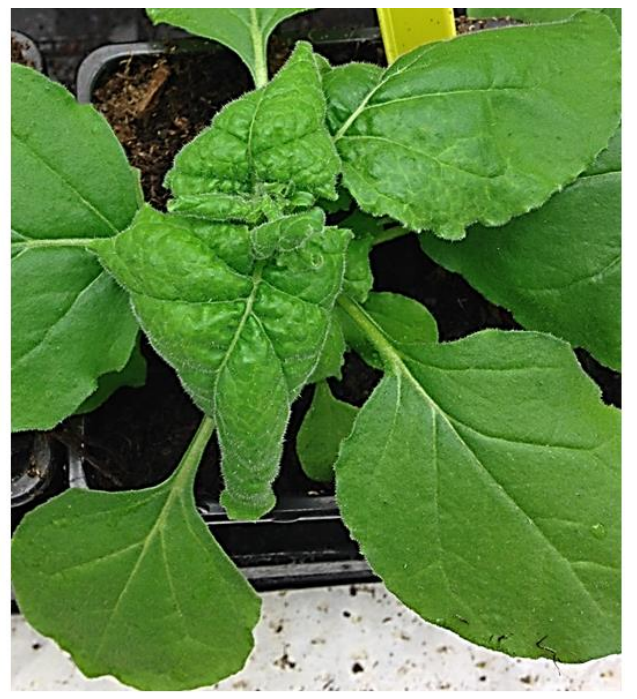

$\operatorname{GRSV}(+)$ (c)

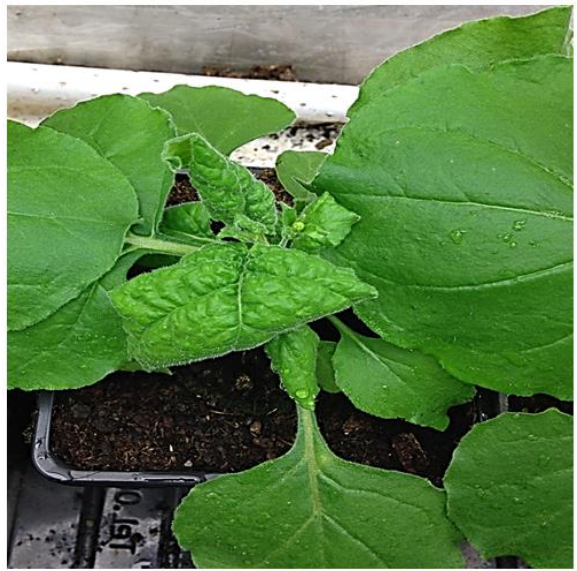

TCSV (+)

Figura 25. (a) Plantas de Nicotiana benthamiana infectadas com Groundnut ringspot virus (GRSV) e Tomato chlorotic spot virus (TCSV) por inoculação mecânica. Na planta de $N$. benthamiana no centro da bandeja foi friccionado o tampão de inoculação sem o vírus. Plantas de N. benthamiana inoculadas com (b) GRSV, ou (c) TCSV, dez dias após a inoculação com intensa deformação foliar e enrolamento dos ponteiros, sintomas típicos de tospovirus. 
Tabela 16. Primers específicos sintetizados a partir de sequências da proteína do nucleocapsídeo $(\mathrm{N})$ de Groundnut ringspot virus (GRSV) e Tomato chlorotic spot virus (TCSV). Estes primers foram utilizados nas reações de qRT-PCR para quantificação do número de moléculas de ambas espécies em plantas de Nicotiana benthamiana com infecção simples e/ou mista dessas duas espécies de tospovirus

\begin{tabular}{cccc}
\hline Nome do primer & Sequência 5'- 3' (19-20nts) & $\mathrm{T}_{\mathrm{m}}\left[{ }^{\circ} \mathrm{C}\right]$ & $\begin{array}{c}\text { Temperatura de } \\
\text { anelamento }\left[{ }^{\circ} \mathrm{C}\right]\end{array}$ \\
\hline qGRSV_N_For & TCTAAGGTCAAGCTCACAAA & 60.5 & 60 \\
qGRSV_N_Rev & CAGGTCAAGATTTTCCTGA & 60 & 60 \\
qTCSV_N_For & CAAGTTCAAGCTCACCAGA & 61 & 60 \\
qTCSV_N_Rev & ATTGAATCAAGATTTTCTCC & 58.4 & 60 \\
\hline
\end{tabular}

Os RNAs totais das plantas inoculadas extraídos pelo método Trizol® foram submetidos à RT-PCR com os primers específicos, utilizando a enzima Superscript III ${ }^{\circledR}$ (SSIII). Para obtenção do 'template' das reações de qRT-PCR, primeiramente $2 \mu 1$ $[0.5 \mu \mathrm{g}]$ do extrato de RNA total foi adicionado à reação contendo $1 \mu 1$ de cada primer ('forward' e reverso) $[10 \mathrm{mM}], 1 \mu 1$ solução de dNTPs $[10 \mathrm{mM}][2,5 \mathrm{mM}$ de cada dNTP] e $8 \mu 1$ de água estéril para completar o volume final de $13 \mu 1$. A mistura foi desnaturada à $70^{\circ} \mathrm{C}$ por cinco minutos e em seguida foi resfriado no gelo por um minuto. Ao termino da primeira etapa, foi acrescentado a segunda reação para síntese dos cDNAs. Na segunda etapa foi utilizado $2 \mu 1$ do tampão da enzima 'First Strand' [5x], $1 \mu 1$ do agente redutor DTT (DL-Ditiotreitol) $[0.1 \mathrm{M}]$ para estabilizar a enzima, $0.5 \mu l$ de enzima Superscript III ${ }^{\circledR}$ [200 unids./ $\left.\mu 1\right]$, completando o volume final de $7 \mu 1$ por reação com água estéril. Esta reação foi mantida por uma hora à $55^{\circ} \mathrm{C}$ para síntese da fita complementar de DNA (cDNA), seguido por quinze minutos à $70^{\circ} \mathrm{C}$ para desnaturação final das fitas de DNA sintetizadas in vitro.

As reações de qRT-PCR foram executadas com o 'software' Rotor-Gene $\mathrm{Q}^{\circledR}$, utilizando o kit QuantiNova SYBR Green ${ }^{\circledR}$, ambos Qiagen ${ }^{\circledR}$. Para compor essas reações foram utilizados $5 \mu \mathrm{l}$ do 'multiplex' QuantiNova SYBR Green ${ }^{\circledR}$, contendo o mix de dNTPs, a enzima Taq DNA polimerase, o tampão e dois estabilizadores da enzima, QuantiNova Antibody ${ }^{\circledR}$ e QuantiNova Guard ${ }^{\circledR}, 0,1 \mu 1$ de cada primer ('forward' e reverso) $[10 \mathrm{mM}], 0,2 \mu 1$ da sonda de referência ROX, fornecida no kit QuantiNova SYBR Green ${ }^{\circledR}, 1 \mu 1$ de cDNA, completando o volume final para $10 \mu 1$ de reação. As condições de ciclagem consistiram em uma incubação à $95^{\circ} \mathrm{C}$ por dois minutos para ativar a enzima, seguido por quarenta ciclos de $95^{\circ} \mathrm{C}$ por quinze segundos e $60^{\circ} \mathrm{C}$ por um minuto. Em cada ensaio o 'software' Rotor-Gene $Q^{\circledR}$ verificou a intensidade da fluorescência gerada durante os ciclos e, com isso, forneceu o limite mínimo de captação dos sinais de fluorescência, ou valor de Ct ('Threshold Cycle'). Cada amostra foi analisada em triplicata e as médias dos valores de Ct e do desvio padrão (DP) para 
cada amostra foram calculadas. As amostras controle incluíram RNAs totais de plantas de $N$. benthamiana inoculadas unicamente com GRSV ou TCSV e de plantas sadias, clones da proteína do nucleocapsídeo (N) de GRSV e TCSV, além de água estéril substituindo uma amostra de RNA desde a RT-PCR.

Com a finalidade de se determinar o número de moléculas de RNA de GRSV e TCSV nas amostras, clones da proteína do nucleocapsídeo $(\mathrm{N})$ de ambas as espécies foram diluídos em séries de dez (100x, 1000x, 10000x, 100000x e 1000000x) e utilizados nos ensaios de qRT-PCR para gerar as curvas padrões. A qualidade, concentração e pureza desses clones foram medidas pelo espectrofotômetro NanoVue ${ }^{\mathrm{TM}}$ $\left(\right.$ GE Healthcare ${ }^{\circledR}$ ) e a integridade foi verificada por eletroforese em gel de agarose $1 \%$. O número de cópias do 'template' foi estimado a partir da quantidade de matérial presente nas soluções de DNA plasmidial, contendo os clones da nucleoproteína utilizados para gerar as curvas padrões. Essa correção foi possível utilizando o 'software' Rotor-Gene $\mathrm{Q}^{\circledR}$. O número de cópias de DNA plasmidial nas soluções clonais foi estimado considerando alguns conceitos. Baseado na hipótese de que o par de bases (pb) pesa em média 650 daltons (Da) e partindo da convenção que o dalton (Da), ou unidade de massa atômica (u), equivale à massa molar $(\mathrm{g} / \mathrm{mol})$ de uma substância, o que representa um mol (mol) dessa substância, um mol de par de bases tem massa molar (M) igual a 650g. Assim, a massa molar de qualquer molde de fita dupla de DNA pode ser estimada multiplicando-se 650 pelo comprimento da molécula de DNA. Sendo o mol quantidade de matéria de um sistema e utilizando o número de Avogadro, o qual determina que em um mol de uma substância há $6.022 \times 10^{23}$ moléculas, o número de moléculas da amostra por grama de material pode ser calculado. Para isso deve-se multiplicar o número de Avogadro $\left(6.022 \times 10^{23}\right)$ pela quantidade de material, ou quantidade de mois presentes na amostra. Aqui, a quantidade de material é dada pela concentração das amostras. As concentrações dos clones da $\mathrm{N}$ de GRSV e TCSV foram de 70 e 50ng, respectivamente.

Então, se:

$1 \mathrm{~mol}-6.022 \times 10^{23}$ moléculas

Clone N GRSV [70ng] quantidade de mois

Clone N TCSV [50ng] quantidade de mois

e

número de moléculas $(\mathrm{n})=[\mathrm{DNA}] * 6.022 \times 10^{23}$ 
número de moléculas (n) N GRSV $=70 * 6.022 \times 10^{23}=4.2 \times 10^{25}$

número de moléculas (n) N TCSV $=50 * 6.022 \times 10^{23}=3 \times 10^{25}$

Para determinar o número aproximado de moléculas utilizadas na composição das curvas padrões deve-se calcular a quantidade de moléculas por grama e por fim, o número de moléculas contidas na porção adicionada à reação. Assim, para determinar a quantidade de moléculas por grama, é preciso estipular a massa molar (M) dos plasmídeos. Para isso deve-se determinar o comprimento total do plasmídeo, pois a massa molar (M) é calculada pelo produto do comprimento da cadeia nucleotídica por 650. Assim, tendo a proteína do nucleocapsídeo (N) 777 pb e os plasmídeos pGEM $^{\circledR}$-T Easy $3015 \mathrm{pb}$ e pGreen $3232 \mathrm{pb}$, os quais foram utilizados para clonar a nucleoproteína de GRSV e TCSV, respectivamente, as massas molares dos plasmídeos utilizados são:

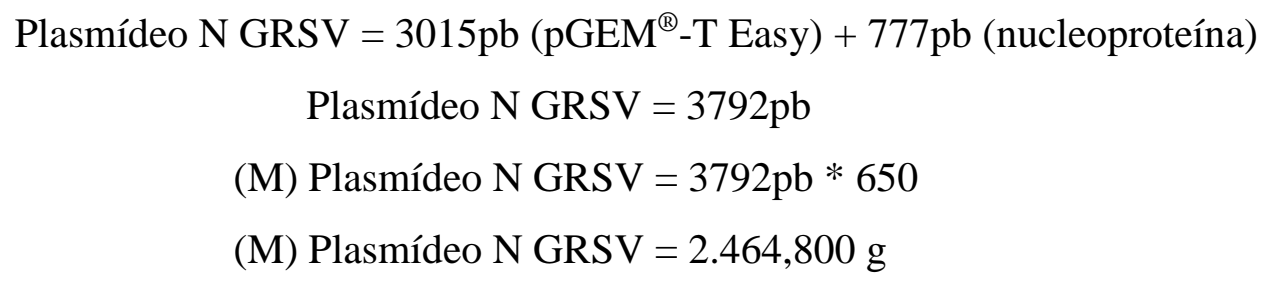

Plasmídeo N TCSV = 3232pb (pGreen) + 777pb (nucleoproteína)

Plasmídeo N TCSV $=4009 \mathrm{pb}$

(M) Plasmídeo N TCSV $=4009 \mathrm{pb} * 650$

(M) Plasmídeo N TCSV $=2.605,850 \mathrm{~g}$

Multiplicando-se as massas molares (M) por $1 \times 10^{9}$, foram determinadas as massas molares em nanogramas (ng):

(M) Plasmídeo N GRSV $=2.464,800 \mathrm{~g} * 1 \times 10^{9}$

(M) Plasmídeo N GRSV $=2.4 \times 10^{15} \mathrm{ng}$

(M) Plasmídeo N TCSV $=2.605,850 \mathrm{~g} * 1 \times 10^{9}$

(M) Plasmídeo N TCSV $=2.6 \times 10^{15} \mathrm{ng}$

Assim, o número de moléculas em um nanograma de material foi calculado:

(M) Plasmídeo N GRSV $=2.4 \times 10^{15} \mathrm{ng}$ 
número de moléculas $(\mathrm{n})$ no total do material $=4.2 \times 10^{25}$

$$
\begin{aligned}
2.4 \times 10^{12} \mathrm{ng}-4.2 \times 10^{25} \text { moléculas } \\
\begin{aligned}
& 1 \mathrm{ng}-\mathrm{n} \text { moléculas } \\
& 2.4 \times 10^{12} \mathrm{ng} * \mathrm{n}= 4.2 \times 10^{25} \text { moléculas } * 1 \mathrm{ng} \\
& \mathrm{n}=\frac{4.2 \times 10^{25} \text { moléculas } * 1 \mathrm{ng}}{2.4 \times 10^{15} \mathrm{ng}} \\
& \mathrm{n}=1.75 \times 10^{10} \text { moléculas/ng de plasmídeo N GRSV }
\end{aligned}
\end{aligned}
$$

(M) Plasmídeo N TCSV $=2.6 \times 10^{15} \mathrm{ng}$

número de moléculas no total do material $=3 \times 10^{25}$

$$
\begin{aligned}
& 2.6 \times 10^{12} \mathrm{ng}-3 \times 10^{25} \text { moléculas } \\
& \text { 1ng - A moléculas } \\
& 2.4 \times 10^{12} \mathrm{ng} * \mathrm{n}=3 \times 10^{25} \text { moléculas } * 1 \mathrm{ng} \\
& \mathrm{n}=\underline{3 \times 10^{25} \text { moléculas } * 1 \mathrm{ng}} \\
& 2.6 \times 10^{15} \mathrm{ng} \\
& \mathrm{n}=1.16 \times 10^{10} \text { moléculas/ng de plasmídeo N TCSV }
\end{aligned}
$$

Estes cálculos realizados para chegar ao número de cópias de DNA por nanograma (ng) de material podem ser resumidos em uma única fórmula desenvolvida por Andrew Staroscik, 2004, que foi disponibilizada por meio de 'software' pela universidade de Rhode Island Genomic and Sequencing Center no endereço eletrônico http://cels.uri.edu/gsc/cndna.html. Portanto, baseado no número de Avogadro, no comprimento $(\mathrm{pb})$ da molécula de DNA e concentração do material, o número de moléculas de DNA por nanograma (ng) de material pode ser calculado da seguinte forma:

$$
\text { número de cópias }(\mathrm{n})=\frac{\left([\mathrm{DNA}(\mathrm{ng})] * 6.022 \times 10^{23}\right)}{\left(\text { comprimento da molécula }(\mathrm{pb}) * 650 * 1 \times 10^{9}\right)} \text { mol }
$$

Curvas padrões para ambos plasmídeos foram construídas e os valores de $\mathrm{Ct}$ foram estipulados por meio de três replicatas por diluição, juntamente com número de cópias por nanograma. A eficiência de amplificação (E) dos primers é baseada numa curva linear gerada com os valores correspondentes ao decaimento da fluorescência 
(slope) e ambas são calculadas pelo software Rotor-Gene $\mathrm{Q}^{\circledR}$. A eficiência de amplificação (E) deve oscilar entre 90\% - 110\%. Outro quesito importante é o coeficiente de correlação $\left(\mathrm{R}^{2}\right)$ que tem que estar muito próximo de $1(\geq 0.985)$. Este coeficiente está associado à curva linear, a qual deve manter a linearidade por todas as séries de diluições.

\subsection{Estudo de ancestralidade dos RNAs M de TCSV e GRSV}

O sequenciamento completo dos genomas parentais de TCSV e GRSV armazenados à $-80^{\circ} \mathrm{C}$ no Dept. de Virologia da Universidade de Wageningen, foi realizado por sequenciamento de alta performance, ou sequenciamento de nova geração (NGS). Os estudos de ancestralidade de GRSV e TCSV foram concentrados no RNA M, contudo, os RNAs S e L também foram analisados. As sequências nucleotídicas dos isolados SA-05 (GRSV) e BR-03 (TCSV) foram analisadas juntamente com outras disponíveis no banco de dados GeneBank® (http://www.ncbi.nlm.nih.gov) e sequências que compõem o banco de dados viral mantido pelo laboratório de Virologia Vegetal da Universidade de Brasília, ainda não publicadas. Os alinhamentos múltiplos das sequências selecionadas foram realizados com o programa MUSCLE e as análises filogenéticas feitas pelo software PhyML, ambos por meio da multiplataforma SeaView v.4.5.4 (Edgar, 2004; Guindon et al., 2009; Gouy et al., 2010). O método 'maximum likelihood' (ML) foi utilizado para inferir as relações filogenéticas entre os isolados. O modelo de substituição foi estimado por meio do programa JmodelTest versão 2.1.4 (Darriba et al., 2012). Extensivas análises filogenéticas do RNA S, RNA M e RNA L foram realizadas e as árvores geradas visualizadas no programa FigTree v.1.3.1 (Figuras 33-35).

As taxas de substituições sinônimas $\left(d_{\mathrm{S}}\right)$ e não sinônimas $\left(d_{\mathrm{N}}\right)$ de nucleotídeos nas sequências codantes dos três segmentos de RNA foram calculadas utilizando o programa SynPlot2 (Firth, 2014). Estas análises são baseadas nas reconstruções filogenéticas dos RNAs S, M e L e demonstram a possibilidade de ocorrer mutações positivas nas cadeias de aminoácidos que compõem as proteínas. A razão $d_{\mathrm{N}} / d_{\mathrm{S}}$ determina a ocorrência de seleção positiva nas sequências utilizadas. 


\section{Resultados}

3.1. Análise da capacidade replicativa de Tomato chlorotic spot virus (TCSV) e Groundnut ringspot virus (GRSV) em infecção mista

O experimento para avaliar a capacidade infectiva e de persistência durante o processo de infecção foi realizado através da comparação do acúmulo do genoma viral de GRSV e TCSV inoculados isoladamente e/ou simultaneamente em diferentes concentrações, conforme descrito nos Materiais e Métodos.

Os primeiros sintomas da infecção viral começaram a aparecer sete dias após a inoculação (dpi) mecânica e com 10 dpis as amostras foram coletadas. Todas as plantas inoculadas em todos os três tratamentos apresentaram algum nível de sintoma. Antes das coletas, as plantas foram organizadas em ordem crescente de um a treze de acordo com a severidade de sintomas. As plantas com maior intensidade de sintomas de cada tratamento receberam número um (1), então as plantas menos sintomáticas são as de número treze (13). Os sintomas observados foram deformação foliar, enrolamento dos ponteiros, clareamento de nervuras e clorose. Aos dez dias de inoculação os sintomas na maior parte das plantas inoculadas com o tratamento 10xGRSV:1xTCSV não foram tão severos (Figura 26). Diferentemente, nos tratamentos 1xGRSV:1xTCSV e 1xGRSV:10xTCSV as plantas inoculadas apresentaram fortes sintomas de infecção viral, principalmente aquelas inoculadas com proporções equivalentes de GRSV e TCSV (Figura 27; Figura 28). As folhas apicais sintomáticas foram utilizadas para fazer a extração de RNA total e analisar a replicação dos tospovírus GRSV e TCSV. As amostras um, seis e treze de cada tratamento foram escolhidas para confirmação das infecções por meio de RT-PCR com os primers específicos descritos da Tabela 10 (Figura 29). 
(a)
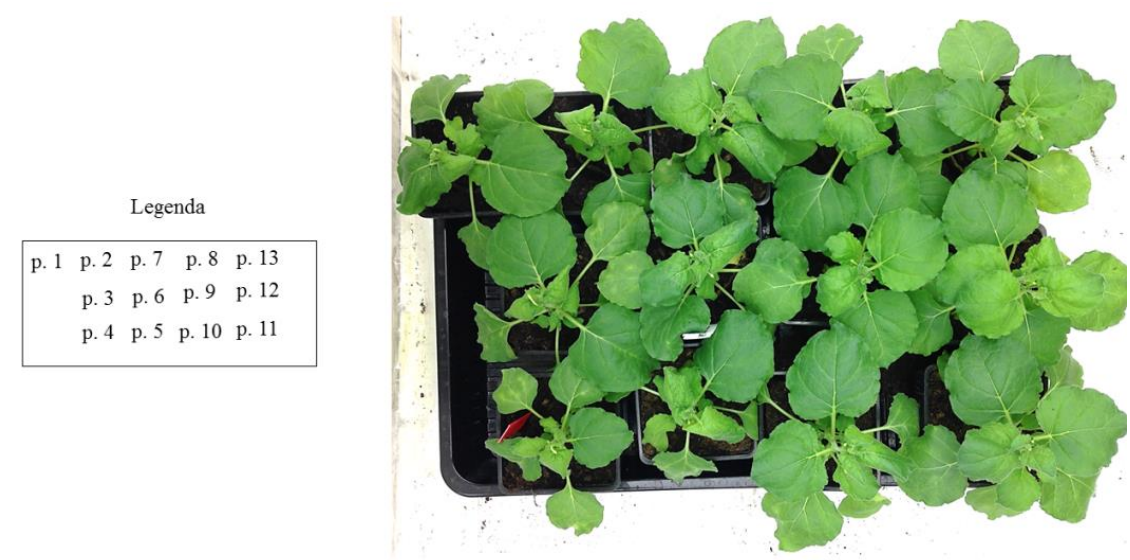

10xGRSV : 1xTCSV

(b)

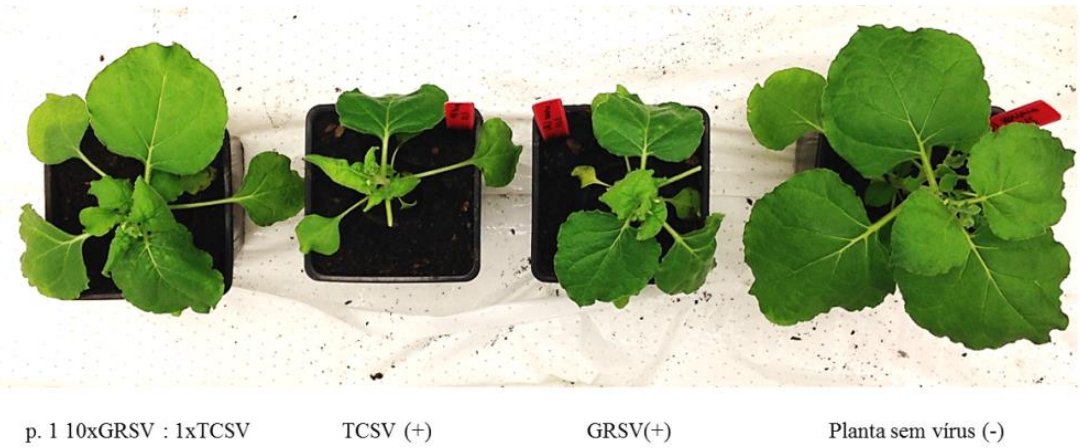

(c)

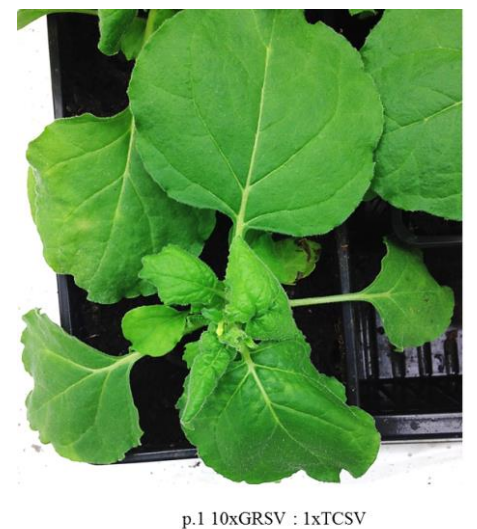

Figura 26. Plantas de Nicotiana benthamiana inoculadas no tratamento 10xGRSV:1xTCSV. (a) Bandeja com as treze plantas utilizadas por tratamento organizadas de acordo com a intensidade de sintomas. A legenda ao lado da foto demonstra a disposição das plantas na bandeja. A planta um (p. 1) é a mais sintomática e a planta treze (p. 13) a menos. (b) Comparação de p. 1 e os controles: planta inoculada apenas com Tomato chlorotic spot virus (TCSV+) ou Groundnut ringspot virus (GRSV+) e planta sem vírus (-). (c) N. benthamiana (p. 1) com deformação foliar, enrolamento dos ponteiros e clorose leves. 
(a)

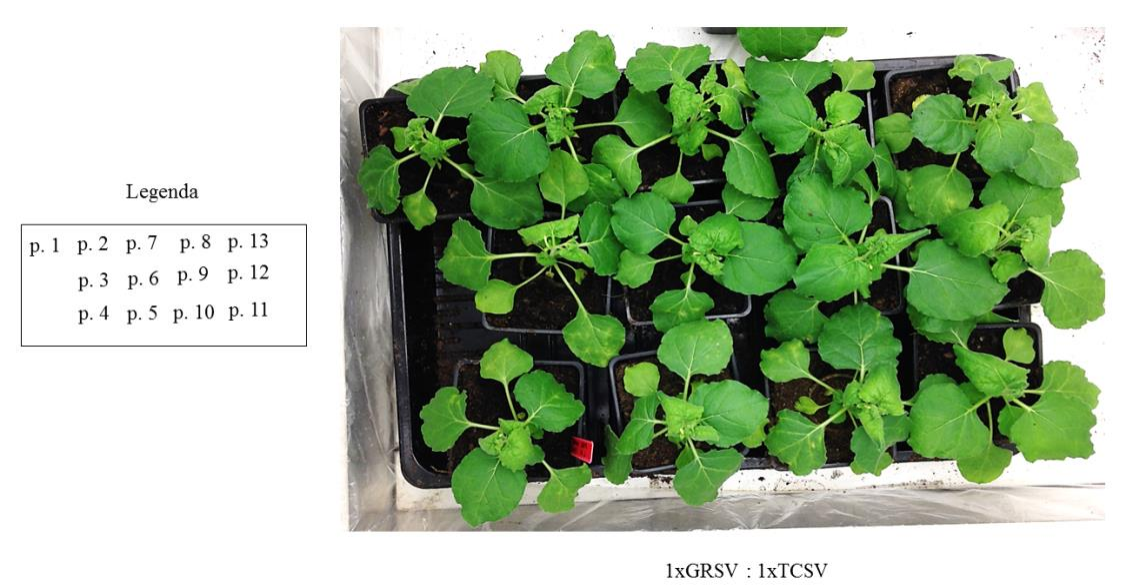

(b)

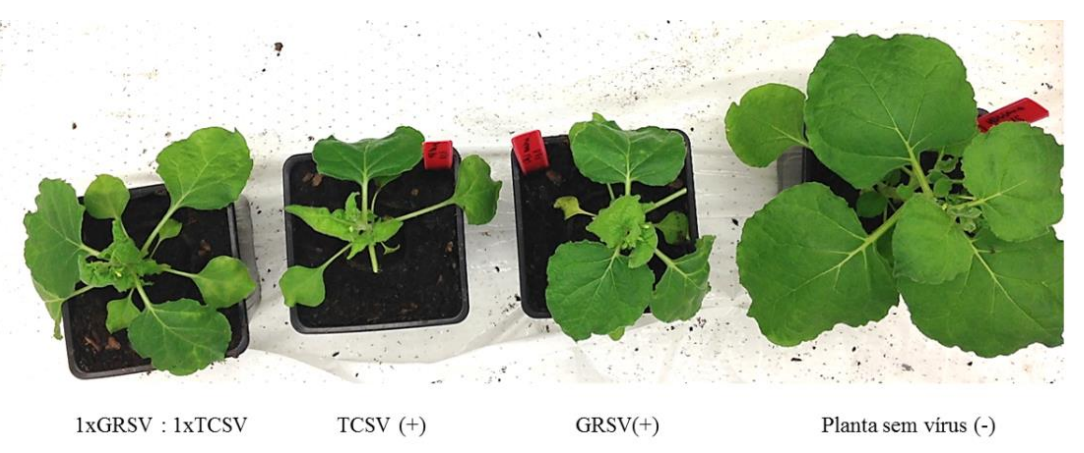

(c)

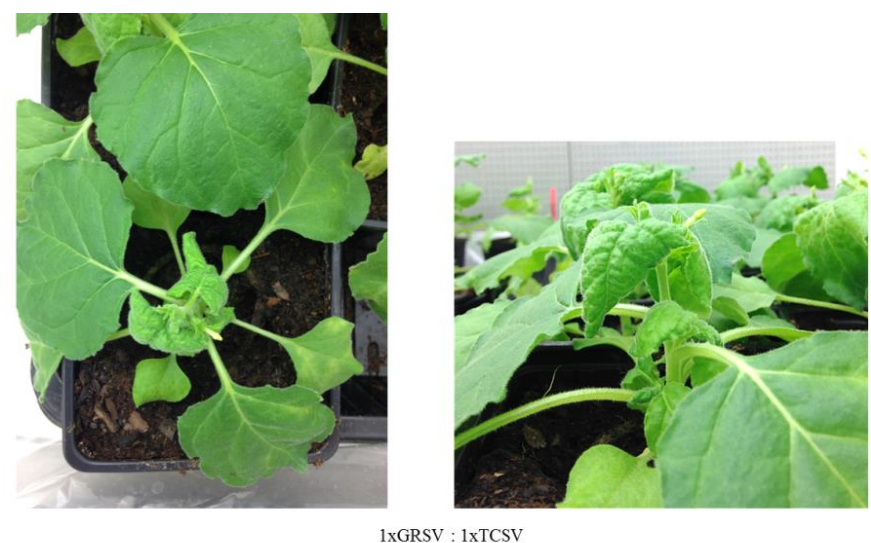

Figura 27. Plantas de Nicotiana benthamiana inoculadas no tratamento 1xGRSV:1xTCSV. (a) Bandeja com as treze plantas utilizadas por tratamento organizadas de acordo com a intensidade de sintomas. A legenda ao lado da foto demonstra a disposição das plantas na bandeja. A planta um (p. 1) é a mais sintomática e a planta treze (p. 13) a menos. (b) Comparação da planta um (p. 1) e os controles: planta inoculada apenas com Tomato chlorotic spot virus (TCSV+) ou Groundnut ringspot virus (GRSV+) e planta sem inoculação de vírus (-). (c) Nicotiana benthamiana (p. 1) com forte deformação foliar, enrolamento dos ponteiros e clorose. 
(a)

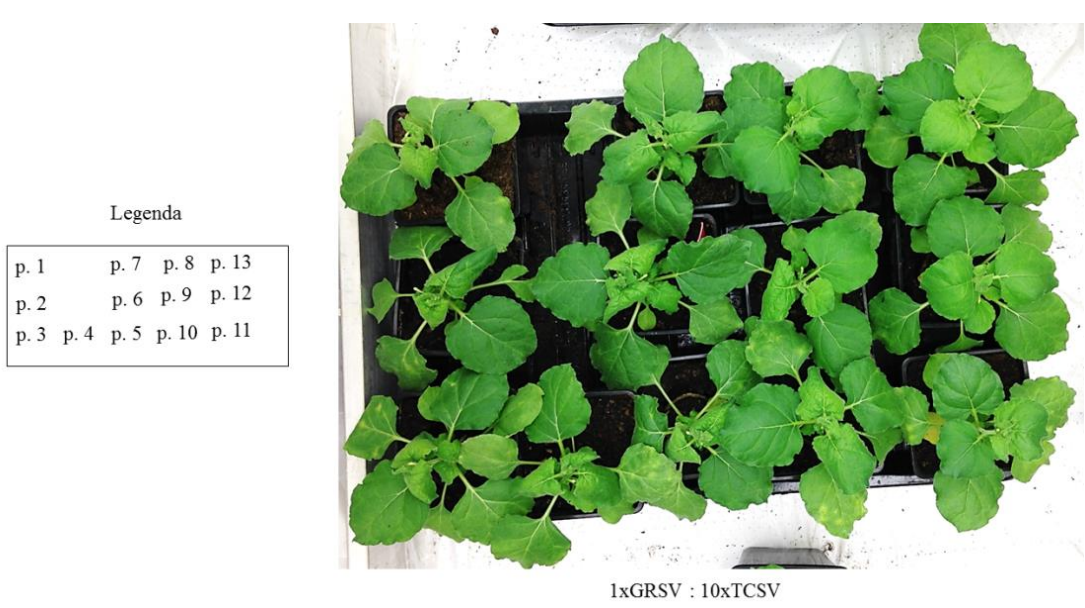

(b)

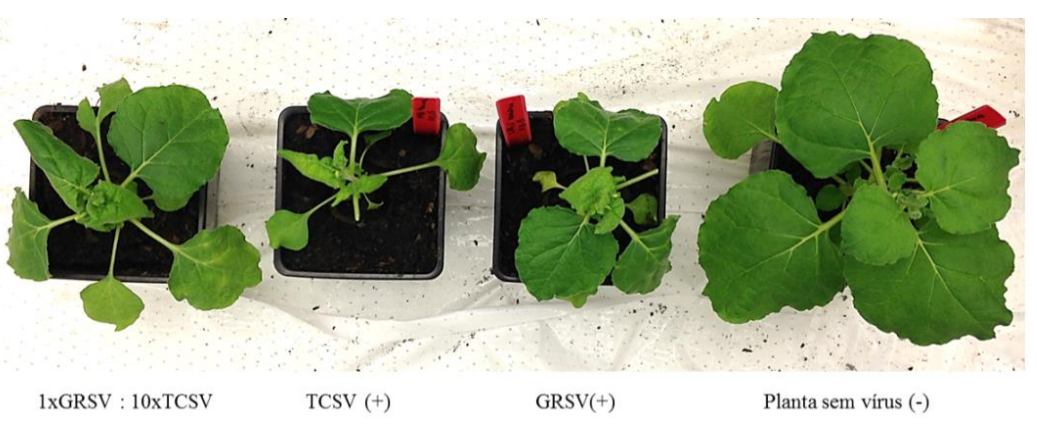

(c)

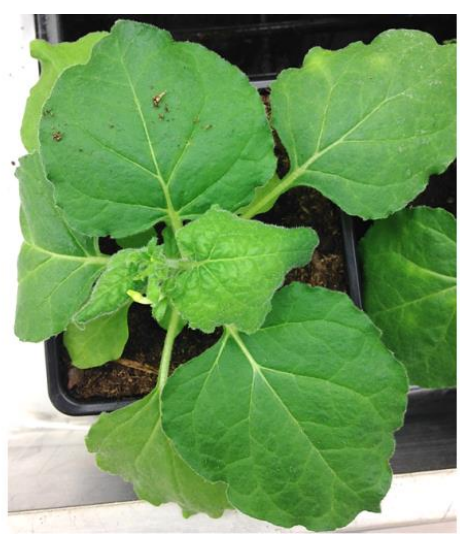

p. 1 1xGRSV : 10xTCSV

Figura 28. Plantas de Nicotiana benthamiana inoculadas no tratamento 1xGRSV:10xTCSV. (a) Bandeja com as treze plantas utilizadas por tratamento organizadas de acordo com a intensidade de sintomas. A legenda ao lado da foto demonstra a disposição das plantas na bandeja. A planta um (p. 1) é a mais sintomática e a planta treze (p. 13) a menos. (b) Comparação da planta um (p. 1) e os controles: planta inoculada apenas com Tomato chlorotic spot virus (TCSV+) ou Groundnut ringspot virus (GRSV+) e planta sem inoculação de vírus (-). (c) Nicotiana benthamiana (p. 1) com deformação foliar, enrolamento dos ponteiros e clorose. 


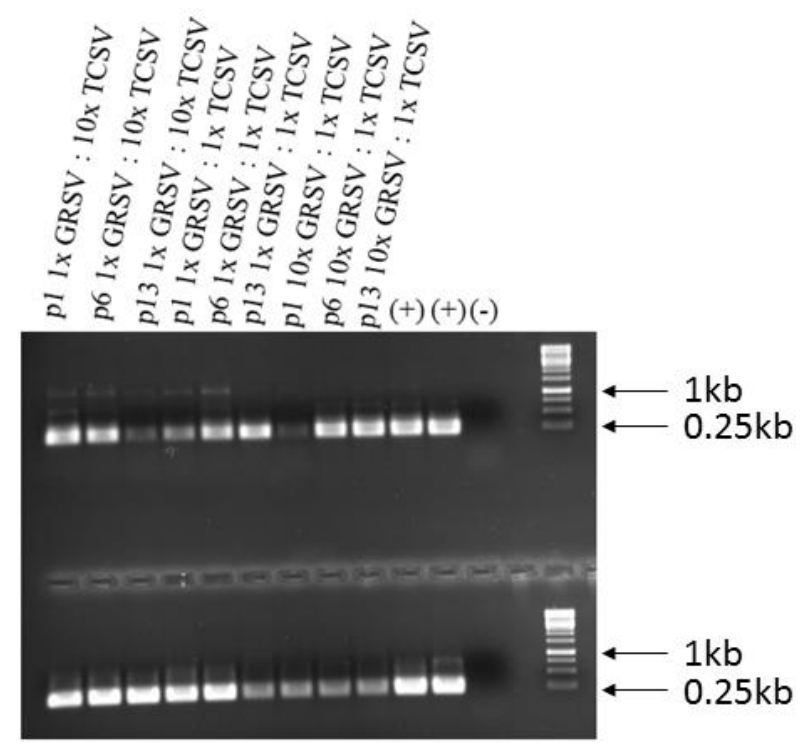

Figura 29. Confirmação da infecção de tospovírus nas plantas de Nicotiana benthamiana inoculadas com Groundnut ringspot virus (GRSV) e Tomato chlorotic spot virus (TCSV) por RT-PCR com primers específicos para detecção do RNA L. Os controles positivos são plantas de N. Benthamiana inoculadas com apenas um dos tospovírus. Marcador de peso molecular: GeneRuler 1kb Ladder, Thermo Scientific.

O número de cópias da proteína N de GRSV e TCSV foi estimado por meio de curvas padrões de cada vírus, utilizando diluições de dez dos clones das proteínas $\mathrm{N}$ de ambos os tospovírus. As curvas padrões obtiveram alcance amplo com a faixa de oito unidades decimais na concentração das amostras e demonstraram forte relação linear, com coeficientes de correlação maiores do que 0,987 e eficiência de amplificação dos primers a partir de $90 \%$ (Figura 30). As curvas padrões geradas foram eficientes na quantificação de $10^{2}$ a $10^{8}$ cópias de parte do gene da proteína N de GRSV e TCSV nos extratos de RNA total. As curvas de 'melting' de ambos os pares de primers apresentaram um pico bastante evidente composto por amplificações na faixa de 75$80^{\circ} \mathrm{C}$ e outro pico menor representando as amplificações na faixa de $62-68^{\circ} \mathrm{C}$ (Figura 31). Baixas concentrações de template foram detectadas nos controles negativos por ambos os pares de primers, contudo, essas moléculas foram amplificadas nos ciclos finais das reações de qRT-PCR, o que sinaliza para amplificação inespecífica. 
(a)

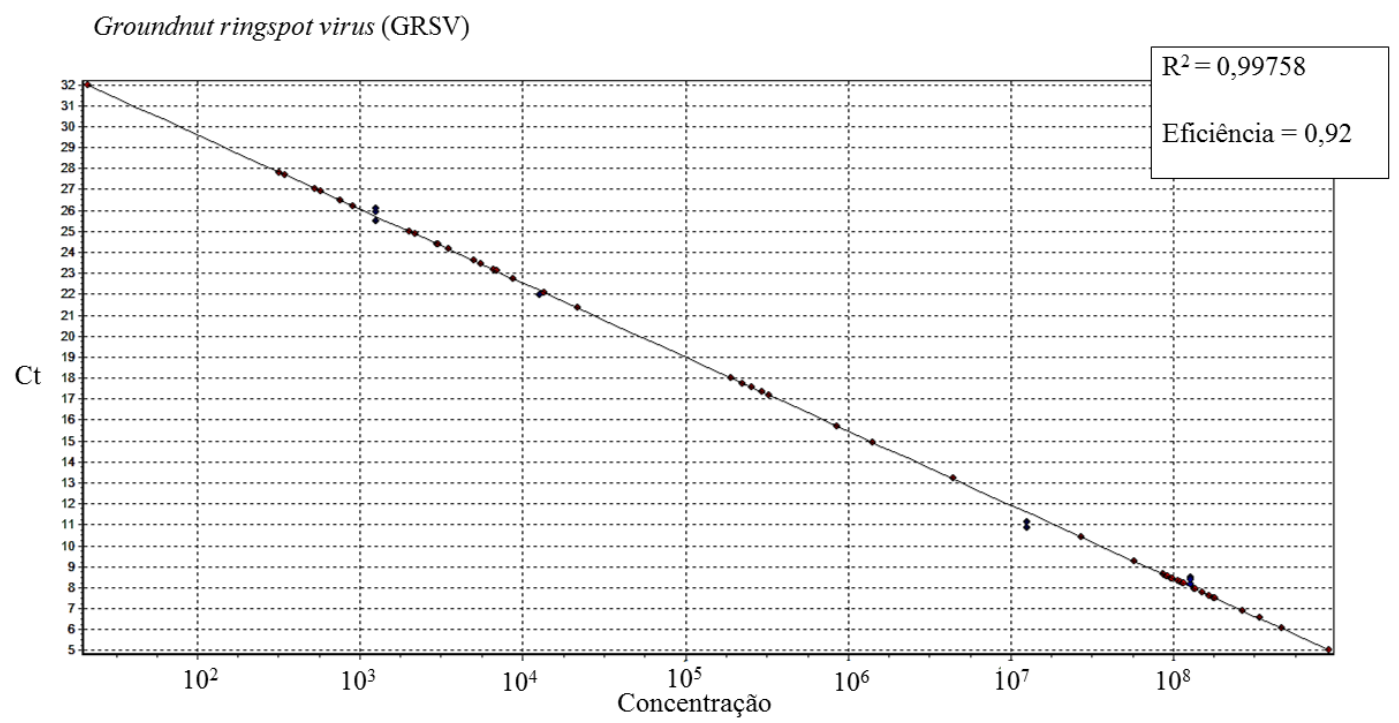

(b)

Tomato chlorotic spot virus (TCSV)

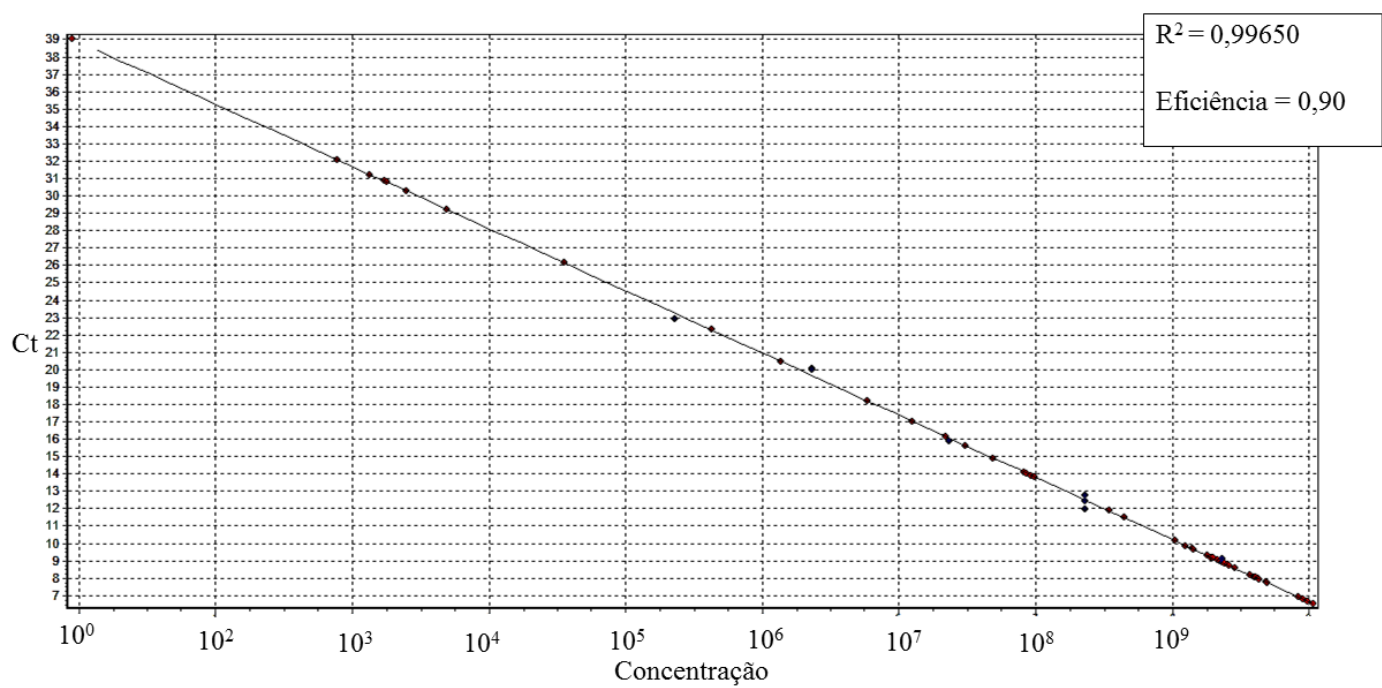

Figura 30. Curvas de regressão linear das amostras infectadas com (a) Groundnut ringspot virus (GRSV) e (b) Tomato chlorotic spot virus (TCSV) adquiridas na qRT-PCR a partir das curvas padrões dos clones da proteína N de GRSV e TCSV. A eficiência do par de primers e o coeficiente de correlação de amplificação estão representados no retângulo do canto superior direito. 
(a)

Groundnut ringspot virus (GRSV)

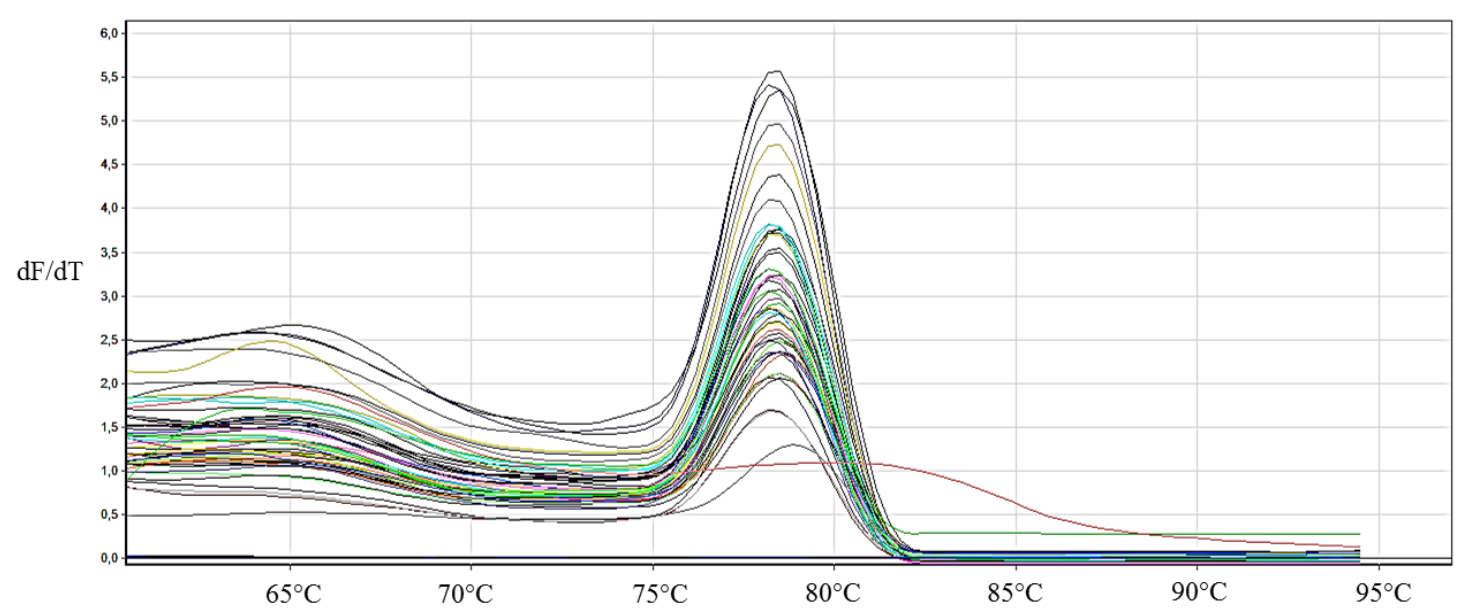

(b)

Tomato chlorotic spot virus (TCSV)

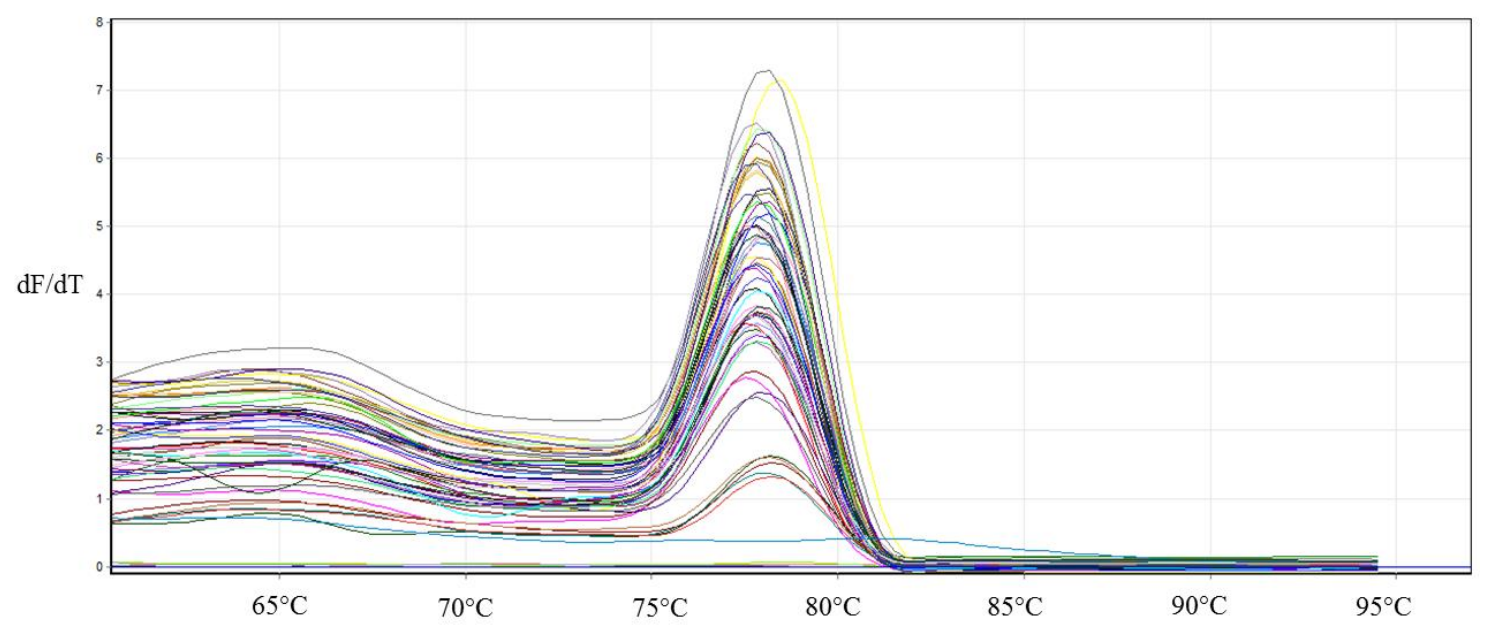

Figura 31. Curvas de 'melting' dos pares de primers (a) qGRSV_N_For + qGRSV_N_Rev e (b) qTCSV_N_For + qTCSV_N_Rev nas reações de qRT-PCR para detectar a proteína N de Groundnut ringspot virus (GRSV) e Tomato chlorotic spot virus (TCSV) em amostras com infecção mista.

Nos ensaios competitivos entre GRSV e TCSV, a quantificação viral nas amostras por meio da qRT-PCR revelou que em uma infecção mista, na qual a quantidade de moléculas de TCSV é significativamente maior do que GRSV (1xGRSV:10xTCSV), este vírus não é capaz de se replicar de forma eficiente (Tabela 17). Em uma situação contrária, na qual a quantidade de moléculas de GRSV é maior do que TCSV (10x GRSV:1x TCSV), a espécie TCSV, ainda assim, apresentou um desempenho superior do que o observado por GRSV, refletido na maior concentração viral detectada nos tecidos infectados (Tabela 18). Contudo, quando inoculados em proporções iguais, a quantidade de moléculas de GRSV detectadas foi equivalente ao 
número observado para TCSV, indicando que as duas espécies se replicaram de forma semelhante (Tabela 19). Na análise global dos experimentos, foi possível demonstrar via qRT-PCR, que o TCSV mostrou uma capacidade replicativa e infectiva superior ao GRSV, mesmo quando coinfectado sob uma alta titulação de GRSV (Figura 32).

Tabela 17. Detecção da quantidade de moléculas de RNA de Groundnut ringspot virus (GRSV) e Tomato chlorotic spot virus (TCSV) em plantas de Nicotiana benthamiana por qRT-PCR. Tratamento 10xGRSV:1xTCSV

\begin{tabular}{ccccc}
\hline \multirow{2}{*}{ Planta } & \multicolumn{2}{c}{ Tratamento 10xGRSV:1xTCSV } & \multicolumn{2}{c}{ TCSV } \\
\cline { 2 - 5 } & Cópias (n) & $\mathrm{Ct} \pm \mathrm{DP} *$ & Cópias (n) & $\mathrm{Ct} \pm \mathrm{DP} *$ \\
\hline Planta 1 & $1,14 \mathrm{E}+08$ & $8,19 \pm 0,17$ & $9,55 \mathrm{E}+06$ & $15,04 \pm 0,10$ \\
Planta 2 & $4,60 \mathrm{E}+08$ & $6,05 \pm 0,18$ & $3,73 \mathrm{E}+06$ & $16,56 \pm 0,12$ \\
Planta 3 & $1,10 \mathrm{E}+08$ & $8,25 \pm 0,32$ & $8,49 \mathrm{E}+08$ & $7,79 \pm 0,22$ \\
Planta 4 & $8,69 \mathrm{E}+07$ & $8,61 \pm 0,30$ & $1,72 \mathrm{E}+08$ & $10,37 \pm 0,18$ \\
Planta 5 & $1,65 \mathrm{E}+08$ & $7,62 \pm 0,14$ & $4,65 \mathrm{E}+07$ & $12,48 \pm 0,70$ \\
Planta 6 & $8,98 \mathrm{E}+07$ & $8,56 \pm 0,16$ & $6,99 \mathrm{E}+05$ & $19,27 \pm 0,11$ \\
Planta 7 & $1,06 \mathrm{E}+08$ & $8,31 \pm 0,11$ & $2,75 \mathrm{E}+06$ & $17,05 \pm 0,17$ \\
Planta 8 & $2,65 \mathrm{E}+08$ & $6,90 \pm 0,20$ & $5,37 \mathrm{E}+06$ & $15,97 \pm 0,30$ \\
Planta 9 & $9,59 \mathrm{E}+07$ & $8,46 \pm 0,33$ & $5,71 \mathrm{E}+06$ & $15,87 \pm 0,10$ \\
Planta 10 & $5,67 \mathrm{E}+07$ & $9,26 \pm 0,15$ & $5,95 \mathrm{E}+04$ & $23,25 \pm 0,24$ \\
Planta 11 & $9,19 \mathrm{E}+07$ & $8,52 \pm 0,17$ & $9,62 \mathrm{E}+06$ & $15,03 \pm 0,16$ \\
Planta 12 & $9,73 \mathrm{E}+07$ & $8,44 \pm 0,13$ & $4,99 \mathrm{E}+03$ & $27,25 \pm 0,50$ \\
Planta 13 & $1,79 \mathrm{E}+08$ & $7,50 \pm 0,40$ & $1,08 \mathrm{E}+07$ & $14,84 \pm 0,29$ \\
GRSV (+) & $1,77 \mathrm{E}+08$ & $7,52 \pm 0,08$ & $7,10 \mathrm{E}+02$ & $30,41 \pm 0,16$ \\
TCSV (+) & $1,36 \mathrm{E}+04$ & $22,06 \pm 0,17$ & $2,56 \mathrm{E}+08$ & $9,73 \pm 0,10$ \\
N. benthamiana (-) & $6,63 \mathrm{E}+03$ & $23,16 \pm 0,10$ & $1,86 \mathrm{E}+02$ & $32,57 \pm 0,11$ \\
\hline
\end{tabular}

*Médias dos valores de Ct ('Threshold Cycle') e do desvio padrão obtidos a partir de três replicatas. 
Tabela 18. Detecção da quantidade de moléculas de RNA de Groundnut ringspot virus (GRSV) e Tomato chlorotic spot virus (TCSV) em plantas de Nicotiana benthamiana por qRT-PCR. Tratamento 1xGRSV:10xTCSV

\begin{tabular}{ccccc}
\hline \multirow{2}{*}{ Planta } & \multicolumn{2}{c}{ Tratamento 1xGRSV:10xTCSV } & \multicolumn{2}{c}{ TCSV } \\
\cline { 2 - 5 } & Cópias (n) & Ct \pm DP* & Cópias (n) & Ct \pm DP* \\
\hline Planta 1 & $7,59 \mathrm{E}+02$ & $26,49 \pm 0,11$ & $3,76 \mathrm{E}+08$ & $9,10 \pm 0,14$ \\
Planta 2 & $2,01 \mathrm{E}+03$ & $24,99 \pm 0,08$ & $3,70 \mathrm{E}+08$ & $9,13 \pm 0,10$ \\
Planta 3 & $3,01 \mathrm{E}+03$ & $24,37 \pm 0,14$ & $3,41 \mathrm{E}+08$ & $9,26 \pm 0,68$ \\
Planta 4 & $2,56 \mathrm{E}+05$ & $17,55 \pm 0,17$ & $1,73 \mathrm{E}+08$ & $10,36 \pm 0,16$ \\
Planta 5 & $5,68 \mathrm{E}+02$ & $26,93 \pm 0,23$ & $3,83 \mathrm{E}+08$ & $9,07 \pm 0,18$ \\
Planta 6 & $2,97 \mathrm{E}+03$ & $24,39 \pm 0,12$ & $2,85 \mathrm{E}+08$ & $9,55 \pm 0,13$ \\
Planta 7 & $5,28 \mathrm{E}+02$ & $27,04 \pm 0,10$ & $1,87 \mathrm{E}+08$ & $10,17 \pm 0,12$ \\
Planta 8 & $9,09 \mathrm{E}+02$ & $26,21 \pm 0,13$ & $3,21 \mathrm{E}+08$ & $9,36 \pm 0,08$ \\
Planta 9 & $3,50 \mathrm{E}+03$ & $24,14 \pm 0,06$ & $1,51 \mathrm{E}+08$ & $10,57 \pm 0,13$ \\
Planta 10 & $2,16 \mathrm{E}+04$ & $21,34 \pm 0,43$ & $1,89 \mathrm{E}+08$ & $10,21 \pm 0,55$ \\
Planta 11 & $3,46 \mathrm{E}+02$ & $27,69 \pm 0,15$ & $1,11 \mathrm{E}+08$ & $11,07 \pm 0,11$ \\
Planta 12 & $2,20 \mathrm{E}+03$ & $24,86 \pm 0,17$ & $2,50 \mathrm{E}+08$ & $9,02 \pm 0,15$ \\
Planta 13 & $3,20 \mathrm{E}+02$ & $27,81 \pm 0,90$ & $4,48 \mathrm{E}+08$ & $8,82 \pm 0,18$ \\
GRSV (+) & $1,33 \mathrm{E}+08$ & $7,96 \pm 0,10$ & $2,86 \mathrm{E}+02$ & $31,88 \pm 0,12$ \\
TCSV (+) & $8,68 \mathrm{E}+03$ & $22,75 \pm 0,13$ & $2,59 \mathrm{E}+08$ & $9,71 \pm 0,14$ \\
N. benthamiana (-) & $5,50 \mathrm{E}+03$ & $23,45 \pm 0,18$ & $1,36 \mathrm{E}+02$ & $33,08 \pm 0,11$ \\
\hline
\end{tabular}

*Médias dos valores de Ct ('Threshold Cycle') e do desvio padrão obtidos de três replicatas.

Tabela 19. Detecção da quantidade de moléculas de RNA de Groundnut ringspot virus (GRSV) e Tomato chlorotic spot virus (TCSV) em plantas de Nicotiana benthamiana por qRT-PCR. Tratamento 1xGRSV:1xTCSV

\begin{tabular}{ccccc}
\hline \multirow{2}{*}{ Planta } & \multicolumn{2}{c}{ Tratamento 1xGRSV:1xTCSV } & \multicolumn{2}{c}{ TCSV } \\
\cline { 2 - 5 } & Cópias (n) & Ct \pm DP* & Cópias (n) & Ct \pm DP* \\
\hline Planta 1 & $1,49 \mathrm{E}+08$ & $7,78 \pm 0,20$ & $8,51 \mathrm{E}+08$ & $7,78 \pm 0,06$ \\
Planta 2 & $4,38 \mathrm{E}+06$ & $13,19 \pm 0,13$ & $1,97 \mathrm{E}+08$ & $10,14 \pm 0,20$ \\
Planta 3 & $8,97 \mathrm{E}+08$ & $5,03 \pm 0,75$ & $1,04 \mathrm{E}+09$ & $7,46 \pm 0,11$ \\
Planta 4 & $1,13 \mathrm{E}+08$ & $8,21 \pm 0,11$ & $4,46 \mathrm{E}+08$ & $8,83 \pm 0,13$ \\
Planta 5 & $3,26 \mathrm{E}+05$ & $17,18 \pm 0,24$ & $4,04 \mathrm{E}+08$ & $8,99 \pm 0,17$ \\
Planta 6 & $3,35 \mathrm{E}+08$ & $6,54 \pm 0,32$ & $7,30 \mathrm{E}+08$ & $8,03 \pm 0,23$ \\
Planta 7 & $8,53 \mathrm{E}+07$ & $8,64 \pm 0,62$ & $1,90 \mathrm{E}+08$ & $10,20 \pm 0,16$ \\
Planta 8 & $1,42 \mathrm{E}+06$ & $14,93 \pm 0,15$ & $1,10 \mathrm{E}+08$ & $11,10 \pm 0,21$ \\
Planta 9 & $8,51 \mathrm{E}+05$ & $15,71 \pm 0,17$ & $2,13 \mathrm{E}+08$ & $10,02 \pm 0,10$ \\
Planta 10 & $2,25 \mathrm{E}+05$ & $17,75 \pm 0,12$ & $1,44 \mathrm{E}+08$ & $10,66 \pm 0,13$ \\
Planta 11 & $2,95 \mathrm{E}+05$ & $17,34 \pm 0,25$ & $2,61 \mathrm{E}+08$ & $9,69 \pm 0,44$ \\
Planta 12 & $2,67 \mathrm{E}+07$ & $10,42 \pm 0,10$ & $3,29 \mathrm{E}+07$ & $13,04 \pm 0,27$ \\
Planta 13 & $1,90 \mathrm{E}+05$ & $18,01 \pm 0,12$ & $1,88 \mathrm{E}+05$ & $21,39 \pm 0,18$ \\
GRSV (+) & $1,34 \mathrm{E}+08$ & $7,94 \pm 0,11$ & $2,79 \mathrm{E}+02$ & $31,91 \pm 0,10$ \\
TCSV (+) & $6,09 \mathrm{E}+03$ & $23,10 \pm 0,27$ & $2,39 \mathrm{E}+08$ & $9,84 \pm 0,09$ \\
N. benthamiana $(-)$ & $5,00 \mathrm{E}+03$ & $23,59 \pm 0,18$ & $2,43 \mathrm{E}+02$ & $32,14 \pm 0,14$ \\
\hline
\end{tabular}

*Médias dos valores de Ct ('Threshold Cycle') e do desvio padrão obtidos a partir de três replicatas. 
(a)

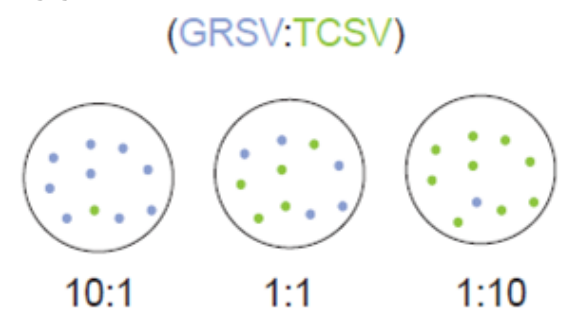

(b)
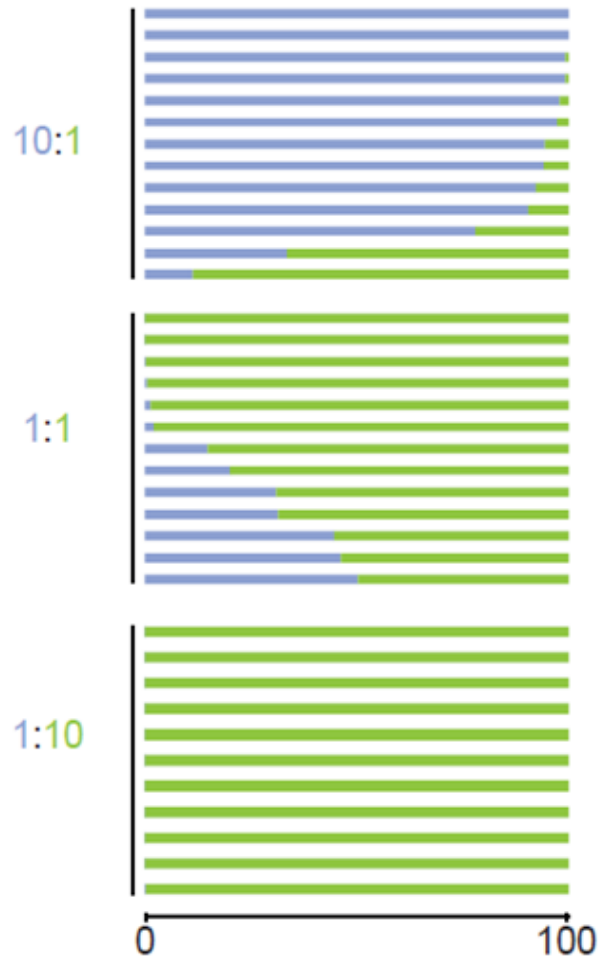

Figura 32. Representação esquemática dos resultados obtidos nas análises de qRT-PCR das amostras com infecção mista de Groundnut ringspot virus (GRSV) e Tomato chlorotic spot virus (TCSV), diante três tratamentos utilizando-se proporções diferentes dos dois vírus no inóculo inicial: (a) 10xGRSV:1xTCSV, 1xGRSV:1xTCSV e 1xGRSV:10xTCSV. As barras de cor azul representam GRSV e as de cor verde o TCSV. (b) A capacidade de acumulação viral do GRSV foi relevante apenas no tratamento 10xGRSV:1xTCSV, sendo prejudicada pela competição com TCSV nos tratamentos em que a concentração inicial de GRSV foi reduzida em relação à TCSV, ou equivalente.

\subsection{Análise de Ancestralidade do RNA M de Tomato chlorotic spot virus (TCSV) e Groundnut ringspot virus (GRSV)}

Extensivas análises filogenéticas foram realizadas, nas quais foi possível observar que as sequências dos RNAs S e L de GRSV e TCSV agrupam-se em clados separados, enquanto que, as sequências correspondentes ao RNA M, formam um mesmo clado. O grau de identidade das sequências nucleotídicas dos três segmentos genômicos de RNA dos isolados de TSWV, GRSV e TCSV foram comparadas. Nestas análises foi possível observar que os segmentos do RNA L de GRSV e TCSV compartilham 81 - 83\% de identidade. Isolados de uma mesma espécie apresentaram mais de $93 \%$ de identidade entre os segmentos L comparados (Figura 33). Os RNAs S de GRSV e TCSV possuem de 83 a $84 \%$ de identidade, enquanto que sequências intraespecíficas apresentaram 83 a 97\% de nucleotídeos idênticos (Figura 34). No 
entanto, as comparações entre os segmentos do M RNA de GRSV e TCSV foram as que mostraram menor divergência interespecífica: 91-95\%. Este intervalo é similar ao observado entre os isolados de TSWV e entre os isolados de GRSV (Figura 35). Isso indica que a diversidade interespecífica no segmento M de GRSV e TCSV se comporta como se esse segmento genômico fosse compartilhado entre as duas espécies. Foi possível observa ainda, que os segmentos M dos isolados de TCSV possuem mais de 97\% de identidade entre si, evidenciando que o polimorfismo é maior entre os isolados de TSWV e GRSV do que TCSV no RNA M.

\section{RNA L}
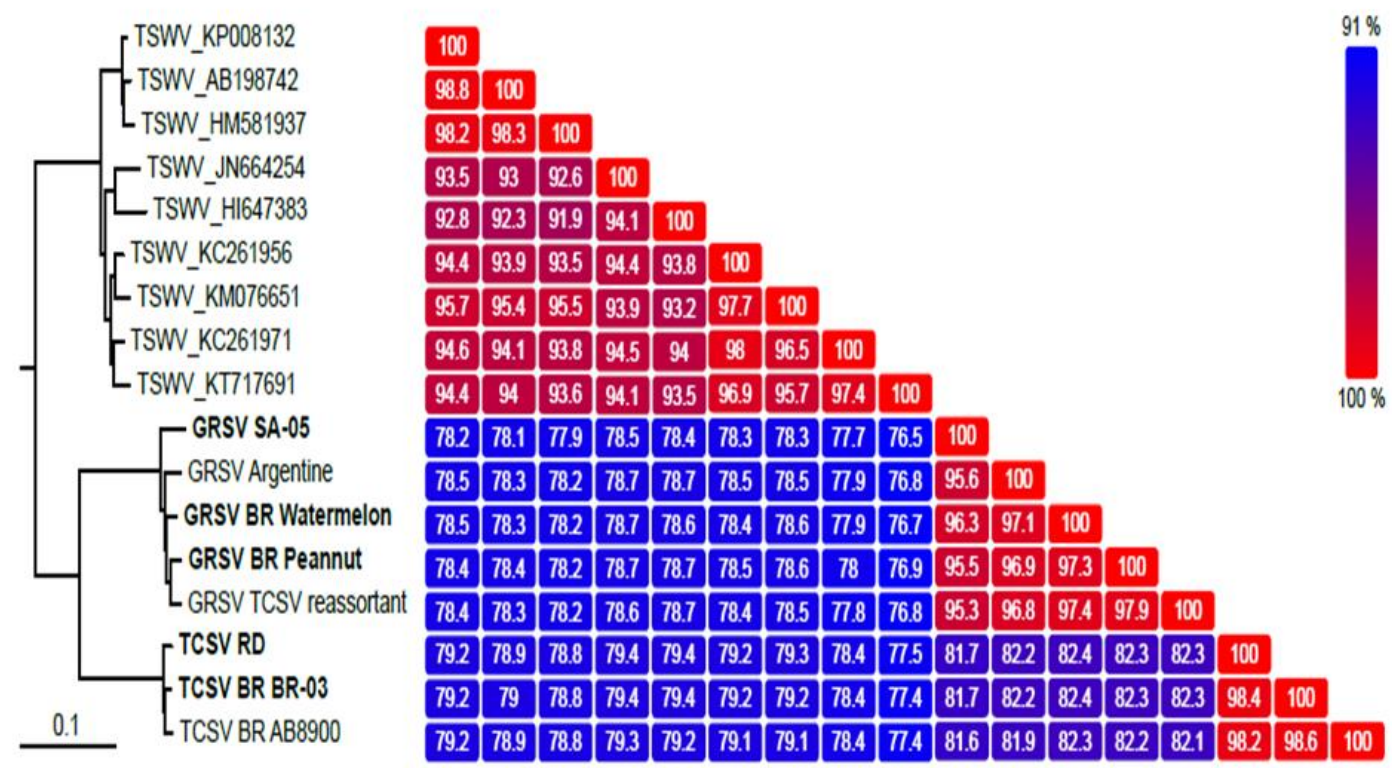

Figura 33. Filogenia do RNA L de Groundnut ringspot virus (GRSV), Tomato chlorotic spot virus (TCSV) e Tomato spotted wilt virus (TSWV), juntamente com a comparação do nível de identidade existente entre os isolados. Os isolados das três espécies se agrupam em clados espécie-específicos. A identidade entre isolados das espécies GRSV e TCSV foi cerca de $80 \%$, menor do que a observada entre isolados da mesma espécie (>93\%). 


\section{RNA S}
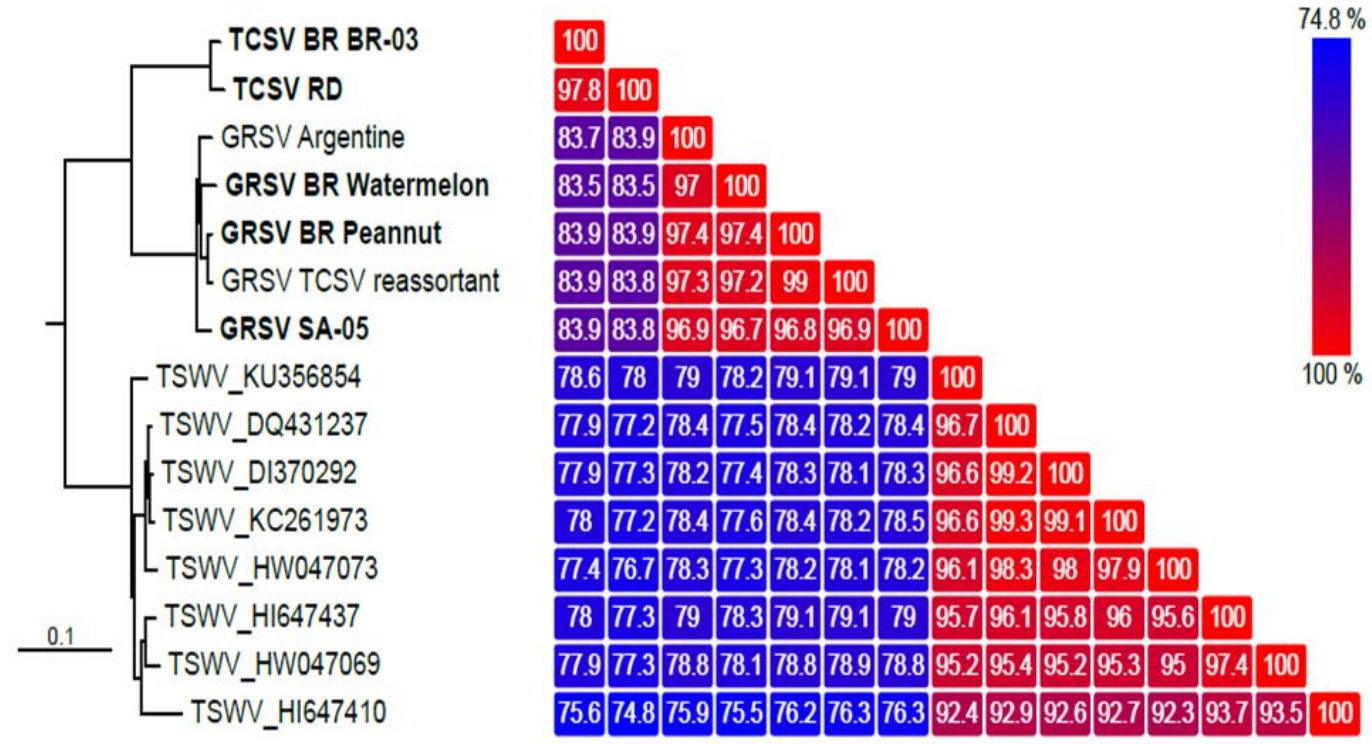

Figura 34. Filogenia do RNA S de Groundnut ringspot virus (GRSV), Tomato chlorotic spot virus (TCSV) e Tomato spotted wilt virus (TSWV) e grau de identidade entre os isolados. Os isolados das três espécies se agrupam em clados espécie-específicos. A identidade entre isolados das espécies GRSV e TCSV foi cerca de 83\%, menor do que a observada entre isolados da mesma espécie (>92\%).

\section{RNA M}
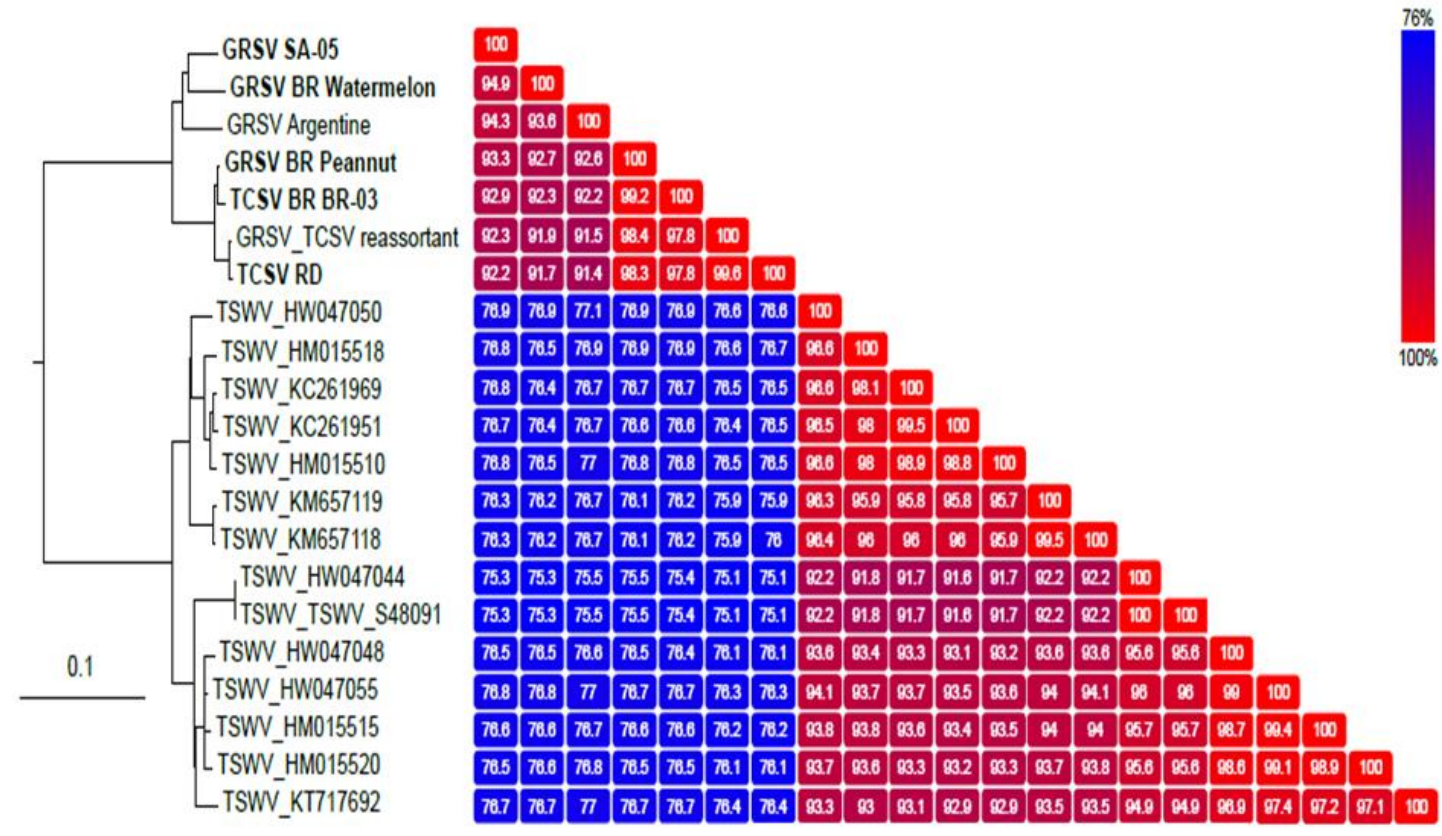

Figura 35. Filogenia do RNA M de Groundnut ringspot virus (GRSV), Tomato chlorotic spot virus (TCSV) e Tomato spotted wilt virus (TSWV) e identidade entre os isolados. Os isolados das espécies GRSV e TCSV compõem o mesmo clado. Os isolados de GRSV e TCSV apresentam mais de $90 \%$ de identidade entre si e a diversidade genética similar a observada entre os isolados de TSWV. 
A ocorrência de seleção positiva $\left(d_{\mathrm{N}} / d_{\mathrm{S}}\right)$ nos segmentos de RNA de GRSV e TCSV foi verificada pelo programa Synplot 2. Nestas análises, valores próximos a um (1) indicam a ocorrência de mutações positivas, enquanto que taxas próximas a 0 determinam ausência ou baixa capacidade acumular mutações positivas. O RNA S mostrou-se mais suscetível às mutações positivas do que os outros segmentos, em especial a proteína N (Figura 36). As análises do RNA M indicam que este não é alvo de mutações sinônimas. Manter o genoma do RNA M com poucas mutações parece ser importante porque é o segmento responsável por codificar as proteínas envolvidas na interação com vetor.

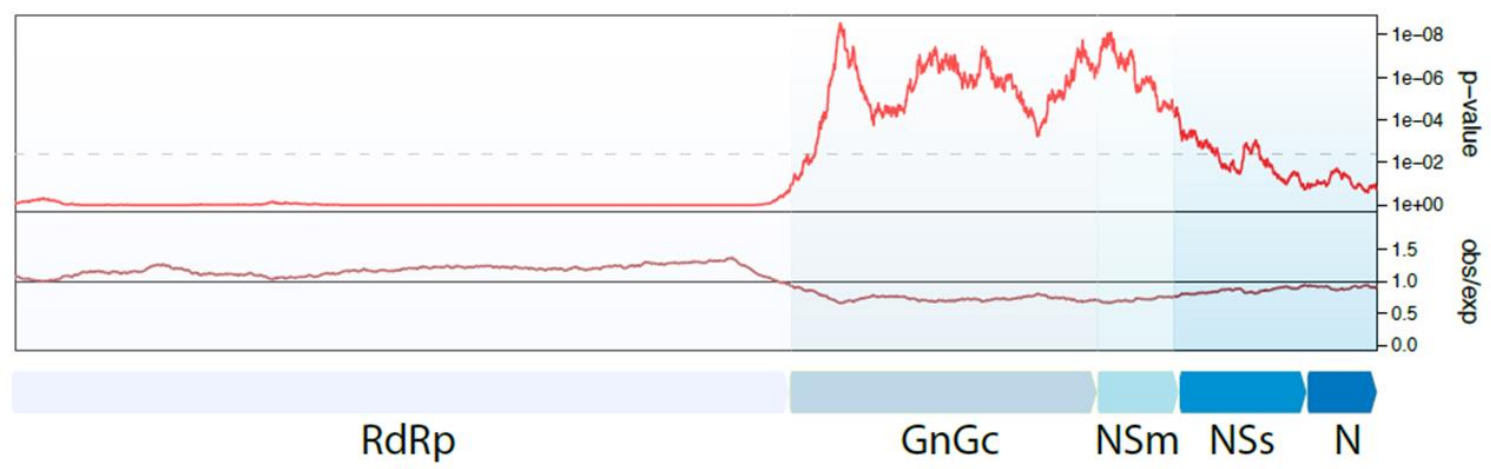

Figura 36. Variabilidade sinônima sítio específica de Groundnut ringspot virus (GRSV) e Tomato chlorotic spot virus (TCSV) analisada pelo programa SynPlot2. O painel de baixo (obs/exp) indica a variabilidade sinônima, representada pela relação entre o número observado e o esperado de substituições sinônimas. O painel de cima corresponde aos valores de $P$ (p-value). A linha pontilhada representa $\mathrm{p}$ value igual a 0.05 .

\section{Discussão}

O 'fitness' é um parâmetro complexo que descreve a capacidade de um organismo de se adaptar ao ambiente. No caso dos vírus, o 'fitness' é resumido como o mecanismo que explica a especialização ao hospedeiro (Domingo et al., 1997; Cervera et al., 2016). Este parâmetro é complexo porque envolve fundamentos de ecologia, epidemiologia, evolução e não se refere apenas à capacidade replicativa (Wargo et al., 2012). Estudos demonstram que a adaptabilidade do vírus ao hospedeiro é o principal fator que favorece o seu desenvolvimento ( $\mathrm{Li}$ et al., 2015). O 'fitness' pode mudar de acordo com o hospedeiro, contribuindo com a especialização viral. Mudar de 
hospedeiro permite que o isolado atinja taxas de replicação inacessíveis nos hospedeiros ancestrais. Ao alcançar uma capacidade replicativa mais eficiente, o isolado se torna mais competitivo e adquiri vantagem evolutiva. Dessa forma, mudanças de hospedeiro resultam em perturbações no padrão de 'fitness' estabelecido (Cervera et al., 2016).

Nos tospovírus a adaptação ao hospedeiro está relacionada à proteína não estrutural NSs codificada no RNA S. Este segmento é o que acumula mais mutações positivas e o que é intercambiado com mais frequência entre isolados de TSWV em eventos de rearranjo genético, sinalizando a plasticidade do RNA S em relação ao ambiente (Tenchev et al., 2011; Margaria et al., 2015). A taxa de substituições sinônimas do RNA S de GRSV e TCSV foi maior do que a observada no RNA M e RNA L (Figura 36). Os RNAs M e L codificam proteínas com funções essencias, como as glicoproteínas responsáveis pela associação ao vetor e à polimerase, respectivamente. Mutações nesses segmentos podem impedir a transmissão e replicação do isolado, por isso são mais conservados. Como interagir com o hospedeiro representa um importante papel no desenvolvimento da espécie, a capacidade de acumular substituições positivas no RNA S pode garantir sucesso evolutivo da espécie.

TCSV foi descrito a primeira vez em tomateiros no Brasil, contudo, até o momento, não foram relatadas ocorrências graves desse vírus no país (de Ávila et al., 1990; de Ávila et al., 1993a; de Ávila et al., 1993b; Nagata et al., 1995; de Ávila et al., 1996; Lima et al., 2000). TCSV no Brasil é comumente isolado de plantas ornamentais (Duarte et al., 2016). Atualmente, devido à recente disseminação pela América, TCSV foi encontrado infectando diversos tipos de plantas, como pimenteiras, tomateiro, feijoeiro, fumo, alface, amendoim, plantas ornamentais e daninhas, demonstrando que está se adaptando rapidamente a diferentes regiões geográficas, o que pode ser explicado por um 'fitness' mais eficiente. O número de espécies de plantas suscetíveis a TCSV cresceu muito e de forma desastrosa em alguns países. (Webster et al., 2010; Londoño et al., 2012; Webster et al., 2013; Almeida et al., 2014; Batuman et al., 2015; Webster et al., 2015; Adegbola et al., 2016; Duarte et al., 2016). TCSV parece possuir a mesma eficiência de transmissão pelo vetor que GRSV e tem demonstrado alta adaptabilidade a diferentes hospedeiros. A replicação viral de TCSV em relação à GRSV em infecção mista foi superior de acordo com as análises de qRT-PCR realizadas neste trabalho. Dessa forma, por meio de considerações epidemiológicas e genéticas, admite-se que TCSV tem um melhor 'fitness' do que GRSV. 
Pode-se esperar que, em um novo ambiente onde há a introdução de espécies de tospovírus, inicialmente, as espécies interagem em um pequeno espaço por um período adaptativo, sendo em seguida observado que as espécies se espalham e se separam, criando seus próprios nichos ecológicos de infecção (Dewey et 1., 1996). No processo adaptativo, associações de espécies virais em infecções mistas possibilitam a colonização de novos hospedeiros quando as espécies que estão interagindo são capazes de adquirir vantagens adaptativas, como eficiência de transmissão pelo vetor, ou de infecção da hospedeira. TCSV e GRSV são capazes de se multiplicar mesmo em competição quando infectam a mesma planta. Devido ao número de moléculas virais produzidas simultâneamente, a interação entre elas é inevitável. Da mesma forma, diversas combinações entre os segmentos de isolados de TSWV foram observadas em infecções de tomateiro e pimenteiras, assim como, a permisibilidade de Datura stramonium a IYSV foi possível devido à interação com TSWV (Tentchev et al., 2011; Sudeep et al., 2012; Margaria et al., 2015). Como a frequência de reassortant entre isolados de TSWV parece ser relativamente alta, pode-se supor, por analogia com TSWV, que em um passado distante, isolados de GRSV e TCSV trocaram constantemente seus segmentos genômicos. Provavelmente, nessas sucessivas trocas, o TCSV manteve o segmento M de GRSV, talvez para garantir eficiência de transmissão pelo vetor e/ou outra vantagem adaptativa ainda desconhecida.

As análises dos RNAs de GRSV e TCSV demonstraram que a variabiliadade genética entre os RNAs M dessas duas espécies é equivalente à encontrada entre isolados de TSWV. A identidade genética observada entre isolados de TSWV pode variar de 91-99\%, enquanto que a observada entre GRSV e TCSV oscila entre 91-98\%. A filogenia dos RNAs M de GRSV e TCSV demonstrou que os isolados dessas duas espécies não são separados em distintos clados, diferentemente do que foi observado para a filogenia dos RNAs S e L (Figuras 33-35). A baixa variabilidade genética entre os RNAs M de TCSV e GRSV e a dificuldade em separá-los em clados filogeneticamente distintos, corroboram com a ideia de que essas espécies compartilham o mesmo RNA M. Um estudo de aquisição e transmissão de GRSV e TCSV pelas espécies de tripes Frankliniella occidentalis, F. schultzei, F. bispinosa e F. fusca demonstrou que não há diferença estatística na capacidade de transmitir GRSV e TCSV pelas espécies de tripes avaliadas (Webster et al., 2015). Além disso, a eficiência de transmissão de GRSV em relação à espécie de tripes é diferente da observada para TSWV (Monteiro et al., 2001; Nagata et al., 2004). Ainda não foi possível determinar com precisão a ancestralidade desse RNA M, devido à falta de dados suficientes para as 
análises filogenéticas, pois as sequências mais antigas datam do final dos anos de 1980, não sendo suficientemente antigas para a determinação com acuidade da ancestralidade. Ainda assim, os dados de sequência disponíveis e obtidos pelo nosso grupo (sequenciamento dos isolados originais armazenados desde 1989), sugerem que a sequência parental do RNA M de GRSV e TCSV é provavelmente, proveniente de um isolado ancestral de Groundnut ringspot virus, pois a frequência de polimorfismo, mesmo que baixa, é maior nos RNAs M provenientes de isolados de GRSV. A identidade genética entre os isolados de GRSV (92-95\%) é maior do que a observada entre os isolados de TCSV (97-99\%), sinalizando maior variabilidade genética. Provavelmente, GRSV acumulou mais mutações do que TCSV, e estaria presente na natureza há mais tempo, acumulando, dessa forma, mais modificações do que TCSV. 


\section{Conclusão final}

Os vírus do gênero Tospovirus são importantes patógenos de plantas. Tomato spotted wilt virus (TSWV) é a espécie-tipo do gênero e é considerada uma das dez espécies de vírus de plantas mais importantes cientificamente e economicamente (Scholthof et al., 2011). Atualmente são conhecidas onze espécies definitivas de tospovírus e mais dezoito aguardam estudos complementares para serem classificadas, sendo consideradas espécies tentativas (de Ávila et al., 1992; de Ávila et al., 1993a; Satynarayana et al., 1996; Nagata et al., 1998; Qiu et al., 1998; Satynarayana et al., 1998; Bezerra et al., 1999; Kato el al., 2000; Chu et al., 2001; McMichael et al., 2002; Chen et al., 2005; Hassani-Mehraban et al., 2005; Dong et al., 2008; Ciuffo et al., 2009 Hassani et al., 2010; Li et al., 2011; Seepiban et al., 2011; Zhou et al., 2011; Oliveira et al., 2012; Torres et al., 2012; Dong et al., 2013; Meng et al., 2013; Smith et al., 2013; Cheng et al., 2014; ICTV, 2015; Margaria et al., 2014; Shimomoto et al., 2014; Yin et al., 2014) (Tabela 5). Tospovirírus foram relatados em todos os continentes e permanecem em expansão (Pappu et al., 2009). A evolução de tospovírus parece ser baseada principalmente via produção de rearranjos virais intra e interespecíficos. Este mecanismo, apesar de ocorrer de forma restrita, permite aumentar a dispersão das espécies de Tospovirus, possibilitando a formação e ascensão de novos isolados (Tentchev et al., 2011; Cervera et al., 2016). Mudanças no genoma dos vírus podem levar a um ganho de 'fitness', o que torna o isolado mais competitivo.

Relatos da ocorrência de rearranjos são mais comuns entre isolados de TSWV. Estudos com variantes de TSWV observaram que o RNA S é o principal alvo nos eventos de rearranjo genético (Tentchev et al., 2011; Lian et al., 2013; Margaria et al., 2015). O rearranjo intraespecífico de espécies de tospovírus é viável em condições experimentais e raro na natureza. Até o momento, apenas um provável isolado composto pelos os segmentos L e S de GRSV e o segmento M de TCSV foi encontrado infectando plantas de tomate na Flórida, Estados Unidos (Webster et al., 2011). Pelo fato de o principal critério taxonômico dos tospovírus ser baseado na identidade da sequência de aminoácidos da proteína do nucleocapsídeo $(\mathrm{N})$, a composição genômica das espécies de tospovírus foi questionada. Com o objetivo de estudar a formação e verificar a existência de rearranjos naturais, foram desenvolvidos marcadores moleculares para cada segmento genômico visando diferenciar as espécies GRSV, TSWV e TCSV em amostras com sintomas de vírus coletadas no campo, no Brasil e na República Dominicana. 
Rearranjos não foram encontrados e a incidência de infecção mista foi baixa. GRSV foi a espécie mais abundante nas amostras brasileiras, TSWV foi detectado apenas em infecção mista com GRSV e TCSV foi encontrado em somente duas amostras (Tabela 11). A predominância de GRSV nos campos brasileiros é crescente desde os anos de 1990, principalmente no tomateiro e pimenteiras (Nagata et al., 1995; de Ávila et al., 1996; Lima et al., 2000). Este cenário pode ser justificado pela distribuição dos insetos vetores no país e pela especialização vírus-hospedeira. Na maior parte das áreas agricultáveis do Brasil, há a ocorrência do tripes Frankliniella shultzei, o principal vetor de GRSV (Figura 19) (Lima et al., 2000; Monteiro et al., 2001; Nagata et al., 2004). A planta hospedeira também executa importante papel na manutenção de um vírus no ambiente, sendo responsável por gerar pressões de seleção nos isolados, que o forçarão a se adaptar à custa de se manter viável. Assim, o vírus precisa evoluir com a hospedeira, que é a representação maior de seu ambiente (Li et al., 2015; Cervera et al., 2016). Considerando que, a maioria das amostras brasileiras coletadas neste trabalho são de tomateiro, que o índice de infecção mista foi de $7 \%$ e que existe uma constante disseminação de GRSV em campos de tomate, fica evidente a adaptabilidade de GRSV a essa hospedeira. Em contraste à situação brasileira, na República Dominicana foi verificada e confirmada a rápida expansão de TCSV pela América Central. Este vírus foi encontrado em variadas culturas, como feijoeiro, fumo, pimentas e pimentões e em diferentes províncias, sendo o primeiro relato de TCSV em feijoeiro e pimenta picante no país (Apêndice I). Não foram encontrados rearranjos ou infecções mistas de tospovírus nas amostras da República Dominicana.

Devido à intensidade, severidade de sintomas e iminência de uma epidemia viral nos campos agrícolas da República Dominicana, algumas amostras coletadas nesse país foram submetidas ao NGS. Essas análises indicaram a presença de quatro espécies de vírus endógenos, que são transmitidos vegetativamente. Vírus endógenos podem integrar partes do seu genoma ao da planta hospedeira. As razões pelas quais esse tipo de interação ocorre são pouco conhecidas. A ocorrência em larga escala desses tipos de vírus parece estar ligada ao fato de que esses não são vírus tão inofensivos como foram descritos anteriormente, pois podem estar relacionados com aumento de patogenicidade em infecções mistas. No entanto, também podem estar associados aos mecanismos de defesa da planta. O fato é que na maior parte dos relatos de infecções de vírus endógenos, as plantas não apresentam sintomas, ou esses são brandos (Lockhart et al., 2000; Horiuchi et al., 2004; Staginnus et al., 2007; Valverde et al., 2007). Normalmente, as coletas para detecção de vírus de plantas são destinadas às plantas sintomáticas, por 
isso há poucos dados disponíveis sobre a epidemiologia de vírus endógenos. Contudo, por meio da metagenômica, o sequenciamento extensivo tornou-se uma importante ferramenta no diagnóstico de doenças virais e descoberta de novos vírus (Sela et al., 2012; Mitter et al., 2013; Prabha et al., 2013; Chandler et al., 2014).

Compreender os padrões de distribuição global dos vírus é uma importante ferramenta para os programas de melhoramento e no desenvolvimento de medidas quarentenárias (Abubakar et al., 2003; Venkataravanappa et al., 2011). A filogeografia reconstrói o estado ancestral de um isolado e determina sua relação filogenética de acordo com o local e o tempo de coleta. A filogeografia de TCSV, TSWV e IYSV revelou que a dispersão a longas distâncias desses vírus, parece estar associada às práticas econômicas executadas pelos países. Além disso, o espalhamento de isolados foi local e não global. Na infecção viral, milhões de moléculas diferentes são formadas durante a replicação, sendo que, aquelas com melhor capacidade replicativa, conseguem se manter na célula hospedeira. A capacidade replicativa vai depender da velocidade com que o vírus constrói estruturas infectivas viáveis, sem ser destruído pelos mecanismos de defesa da planta (Cervera et al., 2016). Adaptar-se ao ambiente é a única forma de permanecer nele, o que obriga os isolados à especialização do seu microambiente.

A capacidade replicativa juntamente com a adaptabilidade a diferentes hospedeiras favorecem o 'fitness' do vírus, ou seja, a habilidade de se manter no ambiente (Cervera et al., 2016). Aparentemente, TCSV possui 'fitness' mais eficiente do que sua espécies-irmã GRSV, apesar de GRSV estar amplamente disseminado no Brasil, em contraste com o TCSV, de ocorrência mais restrita. O experimento de qRTPCR realizado neste trabalho, demonstrou que em infecção mista de GRSV e TCSV em planta experimental de Nicotiana benthamiana, o número de moléculas do gene da proteína $\mathrm{N}$ de TCSV detectadas foi maior do que GRSV, mesmo em combinações nas quais o GRSV era inoculado em maiores concentrações. Fatores epidemiológicos também influenciam na determinação do 'fitness' viral. Ambas as espécies de tospovírus infectam naturalmente plantas do gênero Nicotiana spp. e o tomateiro, o principal hospedeiro coletado. TCSV não foi encontrado em nenhuma amostra de tomateiro na República Dominicana e em apenas uma amostra do Brasil, o que evidência a necessidade de um estudo de 'fitness' para cada novo sistema (Domingo et al., 1997).

$\mathrm{Na}$ tentativa de adquirir 'fitness', os isolados e espécies virais com genoma segmentado podem capturar um segmento inteiro equivalente de outro indivíduo 
('Reassortants'). No entanto, a ocorrência natural de rearranjos entre espécies de tospovírus é um evento raro, mesmo sendo comum entre isolados, o que sinaliza para uma regulação muito sutil desse tipo de mecanismo. $\mathrm{O}$ isolado híbrido detectado nos Estados Unidos ( $\mathrm{S}_{\mathrm{GRSV}} \mathrm{M}_{\mathrm{TCSV}} \mathrm{L}_{\mathrm{GRSV}}$ ) deve ter adquirido essa conformação genômica em um passado muito mais distante do que os primeiros relatos de GRSV e TCSV no mundo. No nosso trabalho, extensivas análises filogenéticas revelaram que os RNAs M dos isolados de GRSV e TCSV não apresentam diferenças significativas que determinem a classificação por espécie desse segmento, ou seja, as espécies de tospovírus GRSV e TCSV compartilham o mesmo RNA M. As diferenças de nucleotídeos observada entre os M RNAs dessas duas espécies são similares aquelas encontradas entre isolados de TSWV. Ressalta-se ainda, que a frequência de polimorfismo é maior nas sequências do RNA M dos isolados de GRSV do que TCSV, apontando que a ancestralidade desses segmentos parece estar ligada ao GRSV. Portanto, nossa hipótese é que o TCSV, em um evento remoto, adquiriu e manteve o M RNA de GRSV, fato que, provavelmente, conferiu vantagens adaptativas aos 'reassortants' de TCSV.

A ocorrência de infecções mistas de vírus de plantas parece ser uma constante e não uma exceção. No entanto, os meios que determinam a coinfecção são desconhecidos, mesmo sendo evidente que alguns gêneros estabelecem mais interações do que outros. No caso dos tospovírus, desvendar as razões que favorecem a coinfecção e o rearranjo é um grande passo na compreensão da evolução das espécies que compõe o gênero Tospovirus. 


\section{Referências bibliográficas}

Abubakar Z et al., 2003. Phylogeography of Rice yellow mottle virus in Africa. Journal of General Virology 84:733-743.

Adam G et al., 1991. Monoclonal antibodies against Tomato spotted wilt virus: characterization and aplication. Ann. appl. Biol. 118:87-104.

Adegbola RO et al., 2016. First report of the natural occurrence of Tomato chlorotic spot virus in peanuts in Haiti. Plant Disease 100(8):1797.

Adkins S et al., 1995. An RNA-dependent RNA polymerase activity associated with virions of Tomato spotted wilt virus, a plant- and insect-infecting bunyavirus. Virology 207:308-311.

Allen WR et al., 1986. Tramsmission of Tomato spotted wilt virus in Ontario greenhouses by Frankliniella occidentalis. Canadian Journal os Plant Pathology 8:33-38.

Almeida MMS et al., 2014. The First Report of Tomato chlorotic spot virus (TCSV) infecting long beans and chilli in Dominican Republic. Plant Disease 98(9):1285.

Avise JC et al., 1987. Intraspecific phylogeography - The mitochondrial - DNA bridge between populations genetics and systematics. Annual Review Ecology Systematic 18:489-522.

Bandla MD et al., 1998. Interaction of Tomato spotted wilt tospovirus (TSWV) glycoproteins with a thrips midgut protein, a pettencional cellular receptor for TSWV. Phytopathology 88(2):98-104.

Batuman $\mathrm{O}$ et al., 2015. First report of Tomato chlorotic spot virus in processing tomatoes in the Dominican Republic. Plant Disease 98(2):286.

Bezerra et al., 1999. Increase of tospoviral diversity in Brazil with the identification of two new tospovirus species, one from chrysanthemum and one from zucchini. Virology 89(9):823-830.

Bedendo IP et al., 1995. Viroses. In: Filho AB et al. Manual de Fitopatologia. São Paulo: Ceres. 899-905.

Bishop DHL et al., 1980. Bunyaviridae. Intervirology 14:125-143. 
Boari AJ et al., 2002. Detection and partial characterization of an isolate of Groundnut ringspot virus in Solanum sessiliflorum. Fitopatologia Brasileira 27(3):249-253.

Boiteux LS et al., 1993a. Sources of resistance to Tomato spotted wilt virus (TSWV) in cultivated and wild species of Capsicum. Euphytica 67:89-94.

Boiteux LS et al., 1993b. Genetic basis of resistance against two tospovirus species in tomato (Lycopersicon esculentum). Euphytica 71:151-154.

Boiteux LS et al., 1994. Inheritance of a resistance specific to Tomato spotted wilt tospovirus in Capsicum chinense 'PI 159236'. Euphytca 75:139-142.

Boiteux LS, 1995. Allelic relationships between genes for resistance to Tomato spotted wilt tospovirus in Capsicum quinense. Theor. Appl. Genet. 90:146-149.

Bocccardo G et al, 1987. Cryptic plant viroses. Adv. Virus Research 32:171-214.

Breuil S et al., 2016. Analysis of the coding-complete genomic sequence of Groundnut ringspot virus suggests a common ancestor with Tomato chlorotic spot virus. Archives of Virology DOI 10.1007/s00705-016-2912-x.

Briddon RW, 2003. Cotton leaf curl disease, a multicomponent begomovirus complex. Molecular Plant Pathology 4(6):421-434.

Brittlebank CC. 1919. Tomato diseases. J Agric 17:231-235.

Bucher et al., 2003. Negative-strand tospoviruses and tenuiviruses carry a gene for a supressor of gene silencing at analogous genomic position. Journal of Virology 77(2):1329-1336.Chapman EJ et al., 2002. Association of L protein and in vitro Tomato spotted wilt virus RNA-dependent RNA polymerase activity. Intervirology 46:177-181.

Cervera $\mathrm{H}$ et al., 2016. Effect of the host species on the topography of fitness landscape for a plant virus. Journal of Virology doi:10.1128/JVI.01243-16.

Chandler JA et al., 2014. Metagenomics hotgun sequencing of a bunyavirus in wildcaught Aedes aegypti from Thailand informs the evolutionary and genomic history of the phleboviruses. Virology 464(465): 312-319.

Chatzivassiliou EK et al., 2002. The efficiency by which Thrips tabaci populations transmit Tomato spotted wilt virus depends on their host preference and reproductive strategy. Virology 92(6):603-609.

Chen CC et al., 2005. A chlorotic spot disease on calla lilies (Zantedeschia spp.) is caused by a tospovirus serologically but distantly related to Watermelon silver mottle virus. Plant Disease 89(5):440-445.

Cheng YH et al., 2014. Identification, characterization and detection of a new tospovirus on sweet pepper. Ann. Appl. Biol. 164:107-115. 
Cho JJ et al., 1989. A multidisciplinary approach to management of Tomato spotted wilt virus in Hawaii. Plant Disease 73(5):375-383.

Chu FH et al., 2001. Serological and molecular characterization of Peanut chlorotic fanspot virus, a new species on the genus Tospovirus. Phytopathology 91(9):858-863.

Ciuffo M et al., 2009. A new Tospovirus sp. in cucurbit crops in Mexico. Plant disease 93(5):467-474.

Clabbers MTB et al., 2014. Tospovirus ambisense genomic RNA segments use almost complete repertoire of stable tetraloops in the intergenic region. Bioinformatics Discovery Notes doi:10.1093/bioinformatics/btu122 :1-5.

Comitê Internacional de Toxonômia de Vírus. Virus taxonomy: 2015 release. Disponível em: http://www.ictvonline.org/virusTaxonomy.asp. Acesso em 15 mar 2016.

Cortês I et al., 1998. Molecular and serological characterization of Iris yellow spot virus, a new and distinct tospovirus species. Virology 88(12):1276-1282.

Costa AS et al., 1941. Identidade do vírus de vira-cabeça e sua inclusão no grupo do vírus de "spotted wilt." Bragantia 1:491-516.

Cuevas JM et al., 2012. Phylogeography and molecular evolution of Potato virus $Y$. PLOS ONE 7(5):e37853.

Cunha HA et al., 2012. Análise Filogeográfica. In: Matioli et al. Biologia Molecular e Evolução. Ribeirão Preto: Holos. 197-215.

Darriba D et al., 2012. jModelTest 2: more models, new heuristics and parallel computing. Nature Methods 9(8):772.

de Ávilia AC et al., 1981. Um vírus do grupo do vira-cabeça do tamteiro isolado de cebola (Allium cepa L.). Fitopatologia Brasileira. 6:525.

de Ávila AC et al., 1990. Serological differentiation of 20 isolates of Tomato spotted wilt virus. Journal of General Virology 71:2801-2807.

de Ávila AC et al., 1992. Characterization of a distinct isolate of Tomato spotted wilt virus (TSWV) from Impatiens. J. Phytopathology 134:133-151.

de Ávila AC et al., 1993a. Classification of tospoviruses based on phylogeny of nucleoprotein gene sequences. Journal of General Virology 74:153-159.

de Ávila AC et al., 1993b. Distinct levels of relationships between tospovirus isolates. Archives of Virology 128:211-227. 
de Ávila AC et al.,1996. Identificação de tospovírus em hortaliças no Submédio São Francisco utilizando DAS-ELISA e DOT-ELISA. Fitopatologia Brasileira 21(4):503-508.

de Ávila AC et al., 2004. Ocorrência de viroses de tomate e pimentão na região do estado do Espírito Santo. Horticultura Brasileira 22(3):655-658.

de Haan $\mathrm{P}$ et al., 1989. Molecular cloning and terminal sequence determination of the $\mathrm{S}$ and M RNAs of Tomato spotted wilt virus. Journal of General Virology 70:34693473 .

de Haan P et al., 1990. The S segment of tomato spotted wilt virus has an ambisense character. Journal of General Virology 71:1001-1007.

de Haan $\mathrm{P}$ et al., 1991. Tomato spotted wilt virus L RNA encodes a putative RNA polymerase. Journal of General Virology 72:2207-2216.

Dewey RA et al., 1997. Cladistic analysis of Tospovirus using molecular characters. Molecular Phylogenetics and Evolution 8(1):11-32.

Dianese EC et al., 2011. Search in Solanum (section Lycopersicon) germplasm for sources of broad-spectrum resistance to four Tospovirus species. Euphytica 180:307-319.

Dianese EC et al., 2015. Diagnose dos vírus de plantas. In: Medeiros RB et al. Virologia Vegetal - Conceitos, fundamentos, classificação e controle. Brasília: UnB. 475506.

Dietzgen RG et al., 2005. Genetic variability of Tomato spotted wilt virus in Australia and validation of real time RT-PCR for its detection in single and bulked leaf samples. Annals of Applied Biology 146:517-530.Dong JH et al., 2008. Characterization of Tomato zonate spot virus, a new tospovirus in China. Archives of Virology 153:855-864.

Diniz AS et al., 2013. Competição e restrição externa na zona do euro. Revista de Econômia Política 1(130):17-40.

Domingo E et al., 1997. RNA virus mutation and fitness for survival. Annual Review Microbiology 51:151-158. 
Dong JH et al., 2013. A new tospovirus causing chlorotic ringspot on Hippeastrum sp. on China. Virus Genes 46:567-570.

Duarte LML et al., 1995. Chrysanthemum stem necrosis caused by a possible novel tospovirus. Journal of Phytopathology 143:569-571.

Duarte LML et al., 2016. First report of Tomato chlorotic spot virus on Mirabilis jalapa. Australasian Plant Disease Notes 11(6):1-6.

Duijsings D et al., 1999. Alfalfa Mosaic Virus RNAs serve as cap donors for Tomato spotted wilt virus Transcription during Coinfection of Nicotiana benthamiana. Journal of Virology 73(6):5172-5175.

Duijsings D et al., 2001. In vivo analysis of the TSWV cap-snatching mechanism: single base complementarity and primer length requirements. The EMBO Journal 20(10):2545-2552.

Dullemans AM et al., 2015. The complete nucleotide sequence of Chrysanthemum stem necrosis virus. Archives of Virology 160:605-608.

Edgar RC, 2004. MUSCLE: multiple sequence alignment with high accuracy and high throughtput. Nucleic Acids Research 32(5):1792-1797.

Eiras M et al., 2012. First report of a tospovirus in commercial crop of cape gooseberry in Brazil. New Disease Reports doi:10.5197/j.2044-0588.2012.025.025 p.25.

Elliot W, 1990. Molecular of the Bunyaviridae. Journal of General Virology 71:501522.

Fargette D et al., 2006. Molecular ecology and emergence of tropical plant viruses. Annual Reviews of Phytopathology 44:245-260.

Fayad-André MS et al., 2011. Spread of viruses in garlic fields cultivated under different agricultural production systems in Brazil. Tropical Plant Pathology 36(6):341-349.

Feng $\mathrm{Z}$ et al., 2016. The ER-membrane transport system is critical for intercellular trafficking of the NSm movement protein and Tomato spotted wilt virus. Plos Pathogens DOI:10.1371/journal.ppat.1005443 1:27.

Fernandes-Carrijo FR et al., 2006. Virologia Vegetal uma Introdução. In: Blum LEB et al., Fitopatologia - O Estudo das Doenças de Plantas. Brasília: Otimismo. 167-195. 
Firth A, 2014. Mapping overlapping functional elements embedded within the proteincoding regions of RNA viruses. Nucleic Acids Research 42(20):12425-12439.

Food and Agricultural Organization, FAO, 1999. Salient trends in world agricultural production, demand, trade and food security. Departamento de Desenvolvimento Econômico e Social. Disponível em: http://www.fao.org/.

Food and Agricultural Organization, FAO, 2013. Disponível em: http://faostat3.fao.org/home/E

Francki RIB et al., 1991. Classification and nomenclature of viruses: fifth report os the Internacional Comitee on Taxonomy of Viruses. Archives of Virology. SpringerVerlag Wien ISBN 978-3-7091-9163-7.

Fuji S et al., 2015. Population dynamics of Iris yellow spot virus in onion fields and lisianthus greenhouses in Japan. Plant Pathology 64:808-816.

Geerts-Dimitriadou et al., 2012. Analysis of the Tomato spotted wilt virus ambisense S RNA-encoded hairpin structure in translation. PLOS ONE 7(2):1-12.

Goldbach R et al., 1994. Possible causes of the emergence of tospovirus diseases. Seminars in Virology 5:113-120.

Gordillo et al., 2008. Screening two Lycopersicon peruvianum collections for resistance to Tomato spotted wilt virus. Plant Disease 92(5):694-704.

Gouy M et al., 2010. SeaView version 4: A multiplatform graphical user interface for sequence alignment and phylogenetic tree building. Mol. Biol. Evol. 27(2):221224.

Gregor W et al., 2004. A distinct endogenous pararetrovirus family in Nicotiana tomentosiformis, a diploid progenitor of polyploid tobacco ${ }^{1[\mathrm{w}]}$. Plant Physiology 134:1191-1199.

Groves C et al., 2016. Seed transmission of Soybean vein necrosis virus: the first Tospovirus implicated in seed transmission.

Harper $\mathrm{CN}$ et al., 2005. Characterisation of pararetrovirus-like sequences in the genome of potato (Solanum tuberosum). Cytogenetic and Genome Research 110:559-565.

Harper SJ et al., 2015. With a little help from my friends: Complementation as a survival strategy for viruses in a long-lived host system. Virology 478:123-125. 
Hassani A et al., 2010. A distinct tospovirus causing necrotic streak on Alstroemeria sp. Archives of Virology 155:423-428.

Hassani-Mehraban A et al., 2005. A new tomato-infecting tospovirus from Iran. Phytopathology 95(8):854-858.

Hedil M et al., 2015. Analysis of tospovirus NSs proteins in suppression of systemic silencing. PLOS ONE DOI:10.1371/journal.pone.0134517 1:18.

Hoffmann K et al., 2001. Overcoming host- and pathogen-mediated resistance in tomato and tobacco maps to the M RNA of Tomato spotted wilt virus. Mol. Plant-Microbe Interact 14:242-249.

Horiuchi et al., 2004. Putative Replication Intermediates in Endornavirus, a Novel Genus of Plant dsRNA Viruses. Virus gene 29(3):365-375.

Hurck JVD et al., 1977. The ribonucleic acid of Tomato spotted wilt virus. Journal of General Virology 36:81-91.

Inoue-Nagata AK et al., 1998. Molecular Characterization of Tomato spotted wilt virus defective interfering RNAs and detection of truncated L proteins. Virology 248:342-356.

Jonghe K et al., 2013. First outbreak of Chrysanthemum stem necrosis virus (CSNV) on potted Chrysanthemum in Belgium. New Disease Reports 28(14).

Kammen et al., 1966. Morphology of Tomato spotted wilt virus. Virology 30(3):574577.

Kato K et al., 2000. Melon yellow spot virus: a distinct species of the genus Tospovirus isolated from melon. Virology 90(4):422-426.

Khankhum S et al., 2015. Two endornaviruses show differential infection patterns between gene pools of Phaseolus vulgaris. Archives of Virology doi:10.1007/s00705-015-2335-0.

King AMG et al., 2012. Virus Taxonomy: Ninth Report of the International Committee on Taxonomy of Viruses. London: Elsevier/Academic Press.

Kikkert M et al., 1999. Tomato spotted wilt virus particle morphogenenis in plant cells. Journal of Virology 73(3):2288-2297.

Knippenberg IV et al., 2005. Tomato spotted wilt virus transcriptase in vitro displays a preference for donnors with multiple base complementarity to the viral template. Virology 335:122-130.

Kiritani K, 2001. Invasive insect pests and plant quarantine in Japan. Extension Bulletin of the Food and Fertilizer Center, Taipei 498:1-12. 
Kirk WDJ et al., 2003. The spread of the western flower thrips Frankliniella occidentalis (Pergande). Agricultural and Forest Entomology 5:301-310.

Kitajima EW, 1965. Electron Microscopy of Vira-Cabeca Virus (Brazilian Tomato Spotted Wilt Virus) Within the Host Cell. Virology 26:89-99.

Kormelink R et al., 1991. The nonstructural protein (NSs) encoded by the ambisense $\mathrm{S}$ RNA segment of Tomato spotted wilt virus is associated with fibrous structure in infected plant cells. Virology 181:459-468.

Kormelink R et al., 1992a. Non-viral heterogeneous sequences at the 5' ends of Tomato spotted wilt virus RNAs. Journal of General Virology 73:2125-2128.

Kormelink R et al., 1992 b. The nucleotide sequence of the M RNA segment of tomato spotted wilt virus, a bunyavirus with two ambisense RNA segments. Journal of General Virology 73:2795-2804.

Kormelink R et al., 1992c. Viral RNA synthesis in tomato spotted wilt virus-infected Nicotina rustica plants. Journal of General Virology 73:687-693.

Kormelink R et al., 1994. Expression and subcellular location of the NSm protein of Tomato spotted wilt virus (TSWV), a putative viral movement protein. Virology 200:56-65.

Krauthausen HJ et al., 2012. Identification and incidence of Iris yellow spot virus in Allium field crops in southwest Germany. European Journal Plant Pathology 134:345-356.

Kuepper G, 2004. Thrips management alternatives in field. Pest Management Technical Note. NCAT, U.S. Department of Agriculture. 1-5.

Law MD et al., 1990. A Tomato spotted wilt like-virus with a serologically distinct $\mathrm{N}$ protein. Journal of General Virology 71:933-938.

Law MD et al., 1991. Nucleotide sequence of the 3 ' non-coding region and $\mathrm{N}$ gene of a serologically distinct tospovirus. Journal of General Virology 72:2597-2691.

Latham LJ et al., 1996. Tomato spotted wilt virus and its management. West Australian Journal Agriculture 4(37):86-91.

Latham LJ et al., 1997. Occurrence of Tomato spotted wilt virus on native flora, weeds and horticultural crops. West Australian Journal Agriculture 48:359-369. 
Leastro MO et al., 2015. The moviment proteins (NSm) of distinct tospoviruses peripherally associate with cellular membranes and Interact with homologous and heterologous NSm and nucleocapsid proteins. Virology 478:39-39.

Li CX et al., 2015. Unprecedented genomic diversity of RNA viruses in arthropods reveals the ancestry of negative-sense RNA viruses.

Lian S et al., 2013. Phylogenetic and recombination analysis of Tomato spotted wilt virus. PLOS ONE 8(5): e63380.

Lima MF et al., 2000. Levantamento e identificação de espécies de tospovírus em tomateiro e pimentão no Submédio do Vale do São Francisco e no Distrito Federal. Summa Phytopatologica 26:205-210.

Lima RN et al., 2016. The complete genome of the tospovirus Zucchini lethal chlorosis virus. Virology Journal 13(123):1-5.

Lockhart BE et al., 1986. Purification and serology of a bacilliform virus associated with banana streak disease. Phytopathology 76:995-999.

Lockhart BE et al., 2000. Characterization and genomic analysis of tobacco vein clearing virus, a plant pararetrovirus that is transmitted vertically and related to sequences integrated in the host genome. Journal of General virology 81:15791585 .

Londoño A et al., 2012. First record of Tomato chlorotic spot virus in the USA. Tropical Plant Pathology 37(5):333-338.

Lovato FA et al., 2008. The $\mathrm{N}$ protein of Tomato spotted wilt virus (TSWV) is associated with induction or programmed cell death (PCD) in Capsicum chinense plants, a hypersensitive host of TSWV. Virus Research 137:245:252.

Margaria P et al., 2007. Evidence that nonstructural protein of Tomato spotted wilt virus is the avirulence determinant in the interaction with resistant pepper carrying the Tsw gene. Molecular Plant-Microbe Interactions 20(5):547-558.

Margaria P et al., 2014. The complete genome sequenceof polygonum ringspot virus. Archives of Virology 159:3149-3152.

Margaria P et al., 2015. Evidence of a tomato spotted wilt virus resistance-breaking strain originated through natural reassortment between two evolutionary-distinct isolates. Virus Research 196(22):157-161. 
Martínez RT et al., 2014. First report of Tomato spotted wilt virus in pepper and tomato in the Dominican Republic. Plant Disease 98(1):163.

Matzke MA et al., 2000. Transgene silencing by the host genome defense: implications for the evolution of epigenetic control mechanisms in plants and vertebrates. Plant Molecular Biology 43:401-415.

Meng JR et al., 2013. First report of Tospovirus in mulberry. Plant Disease 97(7):1001.

McMicahel LA et al., 2002. A new tospovirus serogroup IV species infecting Capsicum and tomato in Queensland, Australia. Australasian Plant Pathology 31(3):231-239.

Mitter $\mathrm{N}$ et al., 2013. Differential expression of Tomato spotted wilt virus-derived viral small RNAs in infected commercial and experimental host plants. PLOS ONE $8(10): 1-14$

Mituti T et al., 2014. Survey of viruses belonging to different genera and species in two noble garlic in Brazil. Scientia Agricola 72(3) 278-281.

Mohamed NA et al., 1973. Protein Composition of Tomato spotted wilt virus. Virology $56: 12-21$.

Mohamed NA, 1981. Isolation and characterization of subviral structures from Tomato spotted wilt vírus. Journal of General Virology 53:197-206.

Monteiro CR et al., 2001. Espécies de Frankliniella (Thysanoptera: Thripidae) de importância agrícola no Brasil. Neotropical Entomology 1:65-72.

Moud LA, 1983. Natural and disrupted patterns of geographical distribution in Thysanoptera (Insecta). Journal of Biogeography 10:119-133.

Nagata T et al., 1995. Occurrence of different tospoviruses in six states of Brazil. Tropical Plant Pathology 20(1):90-95.

Nagata T et al., 1998. First report of natural occurrence of zucchini lethal chlorosis Tospovirus on cucumber and chrysanthemum stem necrosis Tospovirus on tomato in Brazil. Plant Disease 82:1403.

Nagata $\mathrm{T}$ et al., 1999. Tissue tropism related to vector competence of Frankliniella occidentalis for tomato spotted wilt Tospovirus. Journal of General Virology 80:507-15. 
Nagata T et al., 2000. Transmission of Chrysanthemum Stem Necrosis Virus, Recently Discovered Tospovirus, by Two Thrips Species. Journal of Phytopathology 148:123-125.

Nagata $\mathrm{T}$ et al., 2004. The competence of four thrips species to transmit and replicate four tospoviruses. Plant Pathology 53:136-140.

Nakhla MK et al., 1994. Widespread Occurrence of the Eastern Mediterranean Strain of Tomato Yellow Leaf Curl Geminivirus in Tomatoes in the Dominican Republic. Plant Disease DOI: 10.1094/PD-78-0926D.

Nischwitz $\mathrm{C}$ et al., 2007. Phylogenetic analysis of Iris yellow spot virus isolates from onion (Allium cepa) in Georgia (USA) and Peru. Journal of Phytopathology 155:531-535.

Okada R et al., 2011. Bell pepper endornavirus: moleculat and biological properties, and occurrence in the genus Capsicum. Journal of General Virology 92:2664-2673

Okuda M et al., 2003. The S RNA segment determines symptom differences on Tetragonia expansa between two Watermelon silver mottle virus isolates. Physiol Mol Pathol. 62:327-332.

Oliveira AS et al., 2012. Characterization of Bean necrotic mosaic virus: a member of a novel evolutionary lineage within the genus Tospovirus. PLOS ONE 7(6):1-9.

Oliveira AS. The $S w-5$ gene cluster: Analysis of tomato resistance against tospoviruses. Tese - Universidade de Wageningen. Wageningen, 4 dezembro 2015. 158.

Oliveira AS et al., 2016. Cell death triggering and effector recognition by Sw-5 SDCNL proteins from resistant and susceptible tomato isolines to Tomato spotted wilt virus. Molecular Plant Pathology DOI 10.1111/mpp.12439.

Paliwal YC, 1974. Some properties and thrips transmission of Tomato spotted wilt virus in Canada. Can. J. Bot. 52:1177-1182.

Pappu HR et al., 2009. Global status of Tospovirus epidemics in diverse cropping systems: successes achieved and challenges ahead. Virus Research. 141(2):219-36.

Parrella GR et al., 2003. An update of the host range of Tomato spotted wilt virus. Journal of Plant Pathology 85:227-264.

Pereira-Carvalho RC et al., 2015a. Controle de Viroses de Plantas. In: Medeiros RB et al. Virologia Vegetal - Conceitos, fundamentos, classificação e controle. Brasília: UnB. 593-650. 
Pereira-Carvalho RC et al., 2015b. Importância Econômica dos Vírus de Plantas. In: Medeiros RB et al. Virologia Vegetal - Conceitos, fundamentos, classificação e controle. Brasília: UnB. 105-130.

Pittman HA, 1927. Spotted wilt of tomatoes: preliminary note concerning the transmission of the 'spotted wilt' of tomatoes by an insect vector (Thrips tabaci). Journal of the Council of Science and Industrial Research 1:74-77.

Poelwijk FV et al., 1993. Detection of the L protein of the Tomato spotted wilt virus. Virology 197:468-470.

Poelwijk FV et al., 1996. Sequence analysis of the 5' ends of tomato spotted wilt virus N mRNAs. Archives of Virology 141:177-184.

Pozzer et al., 1996. Tospovírus: uma visão atualizada. Revisão Anual de Patologia de Plantas 4:95-148.

Pozzer et al., 1999. Characterization of a Tospovirus Isolate of Iris Yellow Spot Virus Associated with a Disease in Onion Fields in Brazil. Plant Disease 83(4):345-350.

Prabha K et al., 2013. Applications of Next Generation High Throughput Sequencing Technologies in Characterization, Discovery and Molecular Interaction of Plant Viruses. Indian Journal of Virology 24(2): 157-165.

Prins $M$ et al., 1998. The emerging problem of tospovirus infection and nonconventional methods of control. Trends in Microbiology 6(1):31-35.

Qiu WP et al., 1998. Tomato spotted wilt tospovirus genome reassortement and genome segment specific adaptation. Virology 244:186-1994.

Ravi KS et al., 2006. Iris yellow spot virus in onions: a new tospovirus record from India. Plant Pathology Doi: 10.1111/j.1365-3059.2005.01261.x.

Ravnikar M et al., 2003. Detection of Chrysanthemum stem necrosis virus and Tomato spotted wilt virus in Chrysanthemum. $8^{\text {th }}$ Internacional Congress of Plant Pathology. International Society for Plant Pathology.

Raush et al., 2008. Diversity and prevalence of Brazilian bipartite begomovirus species associated to tomatoes. Virus Genes (36):251-258 DOI 10.1007/s11262-007-0184$\mathrm{y}$

Resende RO et al., 1991a. Comparison of polyclonal antisera in the detection of Tomato spotted wilt virus using the double antibody sandwich and cocktail ELISA. Jounal of Phytopathology 132:46-56. 
Resende RO et al., 1991b. Generation of envelope and defective interfering RNA mutants of Tomato spotted wilt virus by mechanical passage. Journal of Genral Virology 72:2375-2383.

Resende RO et al., 1996. New tospoviruses Found in Brazil. Proceedings of the international symposium on Tospovirus and thrips of floral and vegetable crops. Acta Horticulturae 431:78-89.

Ribeiro D et al., 1998. Tomato spotted wilt virus glycoproteins induce the formation of endoplasmic reticulum- and Golgi-derived pleomorphic membrane structures in plant cells. Journal of General Virology 89:1811-1818.

Ribeiro SG, 2006. Diversity and host interactions of tomato infecting begomovirus in Brazil. Tese de doutorado. Universidade de Wageningen, Países Baixos. 148p.

Richert-Pöggeler KR et al., 1997. Petunia vein-clearing virus: A Plant Pararetrovirus with the Core Sequences for an Integrase Function. Virology 236:137-146.

Richmond KE et al., 1998. Characterization of the nucleic acid binding properties of Tomato spotted wilt virus nucleocapsid protein. Virology 248:6-11.

Rlley DG et al., 2011. Thrips vectors of tospoviruses. Journal of Integrated Pest Management 1(2): DOI: 10.1603/IPM10020.

Rossink MJ et al., 2011. The remarkable evolutionary history of endornaviruses. Journal General Virology 92:2674-2678.

Sabanadzovic S et al., 2009. Southern tomato virus: The link between the families Totiviridae and Partitiviridae. Virus Research 140:130-137.

Sabanadzovic S et al., 2011. Properties and detection of two cryptoviruses from pepper (Capsicum annuиm). Virus Gene 43:307-312.

Salgado CL et al., 1980. Doenças das Solanáceas (berinjela, jiló, pimentão e pimenta). In: Galli F et al. Manual de Fitopatologia - Vol. II. Piracicaba: Ceres. 497-510.

Samuel et al., 1930. Investigations on 'spotted wilt' of tomatoes. Australasian Council of Science and Indrustrial Research Bulletin 44:1-46.

Satynarayana T et al., 1996. Peanut bud necrosis tospovirus S RNA: complete nucleotide sequence, genome organization and homology to other tospoviruses. Archives of Virology 141(1):85-98. 
Satynarayana T et al., 1998. Peanut yellow spot virus is a member of a new serogroup of Tospovirus genus based on small (R) RNA sequence and organization. Archives of Virology 143(2):353-364.

Seepiban C et al., 2011. Tomato necrotic rigspot virus, a new tospovirus isolate in Thailand. Archives of Virology 156:263-274.

Sela N et al., 2012. Genome Assembly of Bell Pepper Endornavirus from Small RNA. Journal of Virology 86(14):7721

Schnettler E et al., 2010. Diverging affinity of tospovirus RNA silencing suppressor proteins, NSs, for various RNA duplex molecules. Journal of Virology 84(21):11542-11554.

Scholthof et al., 2011. Top 10 plant viruses in moleculat plant pathology. Molecular Plant Pathology 12(9):938-954.

Shimomoto Y et al., 2014. Identification and characterization of Lisianthus necrotic ringspot virus, a novel distinct tospovirus species causing necrotic disease of lisianthus (Eustoma grandiflorum).

Shyi-Dong Y et al., 1992. Identification of a Tomato spotted wilt virus-like virus on watermelon in Taiwan. Plant Disease 76(8):835-840.

Silva MS et al., 2001. Sequence diversity of $\mathrm{NS}_{\mathrm{M}}$ movement preotein of tospoviruses. Archives of Virology 146:1267-1281.

Smith DL et al., 2013. First report of soybean vein necrosis disease caused by Soybean vein necrosis associated virus in Wisconsin and Iowa. Plant Disease 97(5):693.

Snippe M et al., 2007.The cytoplasmic domain of Tomato spotted wilt virus Gn glycoprotein is required for Golgi localization and interaction with Gc. Virology 363:272-279.

Spassova MI et al., 2001. The tomato gene $S w-5$ is a member of the coiled coil, nucleotide binding, leucine-rich repeat class of plant resistance genes and confers resistance to TSWV in tobacco. Molecular breeding 7:151-161.

Staginnus C et al., 2007. Endogenous pararetroviral sequences in tomato (Solanum lycopersicum) and related species. BMC Plant Biology 7(24):1-16.

Stevens MR et al., 1992. Inheritance of a gene for resistance to tomato spotted wilt viru (TSWV) from Lycopersicon peruvianum Mill. Euphytica 59:9-17.

Storms MMH et al., 1995. The nonstructural NSm protein of Tomato spotted wilt virus unduces tubular structures in plant and insect cells. Virology 214:485-493. 
Sudeep B et al., 2012. Complementation between two tospoviruses facilitates the systemic movement of a plant virus silencing suppressor in an otherwise restrictive host. PLOS ONE 7(10): e44803.

Takeda A et al., 2002. Identification of a novel RNA silencing suppressor, NSs protein of Tomato spotted wilt virus. Federation of European Biochemical Societies 532:75-79.

Takeshita M et al., 2011. Molecular and biological characterization of Chrysanthemum stem necrosis virus isolates from distinct regions from Japan. European Journal of Plant Pathology 131(1):9-14.

Tas PWL et al., 1977a. Purification and serological analysis of Tomato spotted wilt virus. Neth. J. Pl. Path. 83:61-72.

Tas PWL et al., 1977b. The structutal proteins of Tomato spotted wilt virus. Journal of General Virology 36:267-279.

Tentchev D et al., 2011. Evolution and structure of Tomato spotted wilt virus populations: evidence of extensive reassortment insights into emergence processes. Journal of General Virology 92:961-973.

Torres R et al., 2012. Pepper necrotic spot virus, a new tospovirus infecting solanaceous crops in Peru. Archives of Virology 157:609-615.

Uhrig JF et al., 1999. Homotypic interaction and multimerization of nucleocapsid protein of tomato spotted wilt tospovirus: Identification and characterization of two interact domains. Proc. Natl. Acad. Sci. USA 96:55-60.

Ullman DE et al., 1992. Thrips-Tomato spotted wilt virus interactions: morphological, behavioral and cellular components influencing thrips transmission Inc. Advances in Disease Vector Research. Ed.Springer-Verlag. New York p.195-240.

Ullman DE et al., 1993. Tospovirus replication in insect vector cells: immunocytochemical evidence that the nonstructural protein encoded by the $\mathrm{S}$ RNA of the Tomato spotted wilt tospovirus is present in thrips vector cells. Phytopathology 83(4):456-463.

Ullman DE et al., 1995. Compartmentalization, Intracellular transport, and autophagy of Tomato spotted wilt tospovirus proteins in infected thrips cells. Phytopathology 85(6):646-654. 
United States International Trade Commission, USITC, 2007. Monitoring of U.S. imports of tomatoes. USITC publication 3959.

Valdez FJ et al., 2016. Índice de plagas y enfermedades de importancia económica en la Republica Dominicana. Ministerio de Agricultura - Oficina de Ejecución de Proyectos Viceministerio de Extensión y Capacitación Agropecuarias. Departamento de Sanidad Vegetal. 244p.

Valverde RA et al., 2007. Transmission of a dsRNA in bell pepper and evidence that it consists of the genome of an endornavirus. Virus Gene 35:399-403.

Venkataravanappa V et al., 2011. Diversity and phylogeography of begomovirusassociated beta sattelites of okra in India. Virology Journal (8)555:1-13.

Verhoeven JTJ et al., 1996. Detection of a novel tospovirus in chrysanthemum. Acta Horticulturae 432:44-51.

Verkleij FN et al., 1982. Evidence that Tomato spotted wilt virus RNA is a positive strain. Journal of General Virology 58:329-338.

Verkleij FN et al., 1983. Characterization of a defective form of Tomato spotted wilt virus. Journal of General Virology 64:677-686.

Wang M et al., 1990. ELISA detection of various Tomato spotted wilt virus isolates using specific antisera to structural proteins of the virus. Plant Disease 74(2):154158.

Wang $\mathrm{Z}$ et al., 2016. Two newly recorded genera and new species of Thripinae from China (Thysanoptera: Thripidae). Zoological Systematics 41(3):253-260.

Wargo A et al., 2012. Virus fitness: definitions, measurement and current insights. Virus Evolution 2:538-545.

Webster CG et al., 2010. First report of Goundnut ringspot virus infecting tomato in South Florida. Online. Plant Health Progress doi:10.1094/PHP-2010-0707-01-BR.

Webster CG et al., 2011. A natural M RNA reassortant arising from two species of plant - and insect - infecting bunyaviruses and comparison of its sequence and biological properties to parental species. Virology 413:216-225.

Webster CG et al., 2013. First report of Tomato chlorotic spot virus (TCSV) in tomato, pepper, jimsonweed in Puerto Rico. Plant Health Progress doi:10.1094/PHP-20130812-01-BR. 
Webster CG et al., 2015. Emergence of Groundnut ringspot virus and Tomato chlorotic spot virus in Vegetables in Florida and the Southeastern United States. Phytopathology 105(3):388-398.

Wei-te C et al., 2014. Effect of Watermelon silver mottle virus on the life history and feeding preference of Thrips palmi. PLOS ONE 9(7):1-9.

Westmore GC et al., 2013. Genetic and host-associated differentiation within Thrips tabaci Lindeman (Thysanoptera: Thripidae) and its links to Tomato spotted wilt virus-vector competence. Heredity 111:210-215.

Wetering FVD et al., 1996. Tomato spotted wilt tospovirus ingestion by first instar larvae of Frankliniella occidentalis is a prerequisite for transmission. Phytopathology 86(9):900-905.

Whitfield AE et al., 2005. Tospovirus-thrips interactions. Annu. Rev. Phytopathology 43:459-489.

Wijkamp I et al., 1995. Distinct levels of specificity in thrips transmission of tospoviruses. Phytopathology 85(10):1069-1074.

Yin $\mathrm{Y}$ et al., 2014. Identification of a new tospovirus causing necrotic ringspot on tomato in China. Virology Journal 11(213):1-5.

Zheng K et al., 2016. Full-length M and L RNA sequences of tospovirus isolate 2009GZT, which causes necrotic ringspot on tomato in China. Archives of Virology DOI 10.1007/s00705-016-2788-9.

Zhou J et al., 2011. Molecular characterization of a new tospovirus infecting soybean. Virus Genes 43:289-295. 